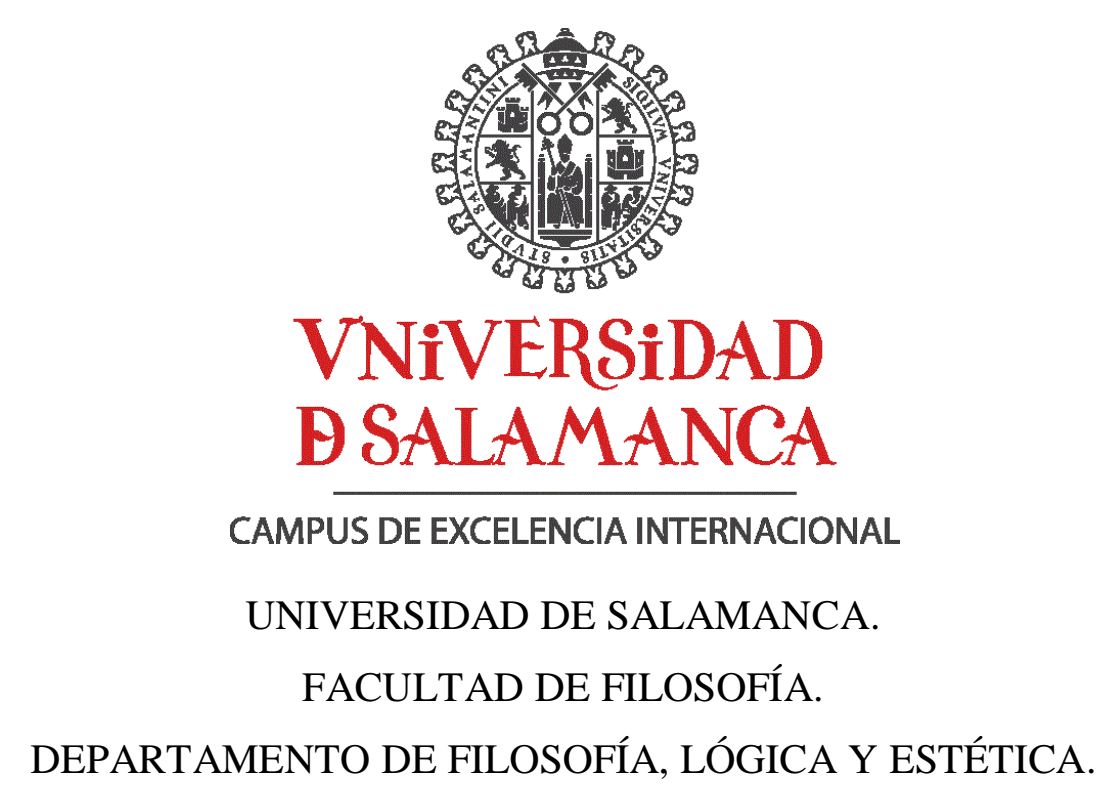

"ELEMENTOS EXISTENCIALES EN

LA FILOSOFÍA DE JOSÉ FERRATER MORA”.

Tesis doctoral para obtener el título de Doctor en Filosofía.

Directora: Dra. Dña María del Carmen Paredes Martín.

Tutor: Dr. D. Francisco T. Baciero Ruiz.

Autora: Dña Ana Josefa Rey de la Fuente.

Salamanca, Junio 2017. 


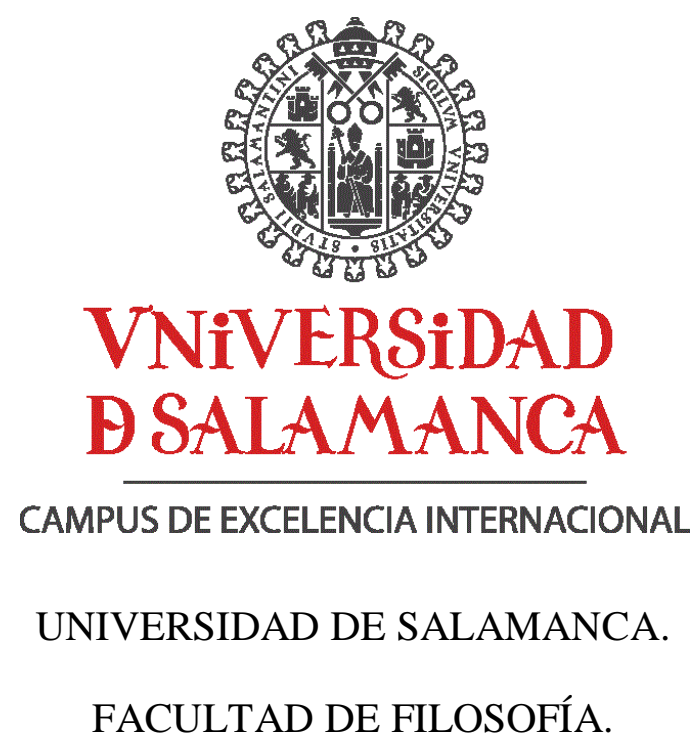

DEPARTAMENTO DE FILOSOFÍA, LÓGICA Y ESTÉTICA.

\section{DECLARACIÓN DE RESPONSABILIDAD.}

Los conceptos desarrollados, analizados así como las conclusiones del presente trabajo de investigación, junto a cualquier tipo de consecuencia derivada por su elaboración, presentación o divulgación, son de la exclusiva responsabilidad de su autora: Ana Josefa Rey de la Fuente*.

Salamanca; Junio 2017. 


\section{DEDICATORIA}

A mis padres, a mi esposo Julián y a mis hijas Estrella Mercedes Rey y Mireya Rey por su abnegación, su energía, motivándome a vivir, avanzar y ofrecer lo mejor de mí. A los lectores de Ferrater Mora, a sus estudiosos y simpatizantes.

A las personas e instituciones que aportaron rayos de luz sobre este sendero.

Ana Josefa Rey de la Fuente. 


\section{AGRADECIMIENTO.}

Concluir esta tesis doctoral ha significado un enorme esfuerzo en tiempo, trabajo y estudio, que sin el apoyo y oportuna orientación brindado por mi directora Dra Doña María del Carmen Paredes Martín, catedrática en la facultad de Filosofía de la Universidad de Salamanca., sencillamente no hubiese sido posible. Gracias por su paciencia, dedicación, motivación, criterio y aliento. Mi directora ha inculcado en mí un sentido de seriedad, responsabilidad, y rigor académico sin los cuales no podría tener una formación completa como investigadora. Ha sido un privilegio contar con su guía y ayuda.

Gracias a todos los docentes de la facultad de Filosofía de la Universidad de Salamanca, por su atención y amabilidad en todo lo referente a mi vida como alumna de doctorado.

Ana Josefa Rey de la Fuente. 


\section{ÍNDICE GENERAL. I.}

Página.

DECLARACIÓN DE RESPONSABILIDAD ................................... II

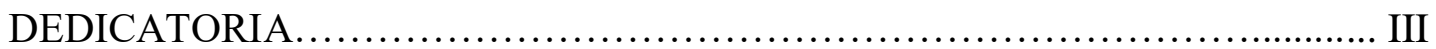

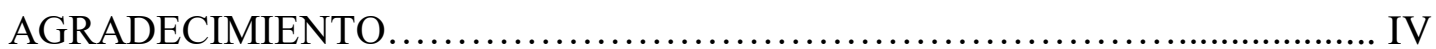

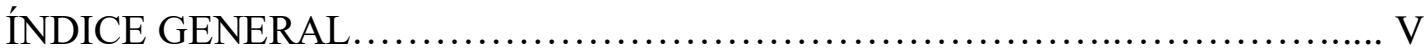

ÍNDICE DE ILUSTRACIONES ........................................... VIII

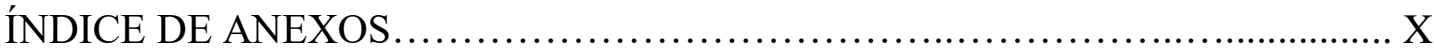

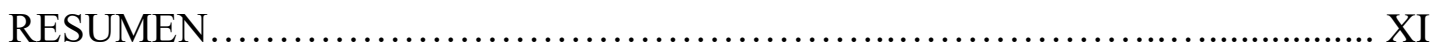

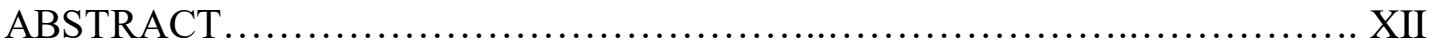

SECCIÓN INTRODUCTORIA................................................ 13

1. Introducción....................................................... 13

2. Justificación.................................................... 29

3. Fines y objetos de la investigación...................................... 34

3.1. Hipótesis...................................................... 34

4. Método de investigación......................................... 36

4.1. Estado de la cuestión.......................................... 36

CAPÍTULO 1: PERFIL INTELECTUAL DE JOSÉ FERRATER MORA........... 40

5. Semblanza de José Ferrater Mora...................................... 40

5.1. Visión historiográfica...................................... 40

5.2. Formación e influencia filosófica............................. 44

6. Contexto social que influencia la vida y obra de José Ferrater Mora....... 57

6.1. Guerra civil y exilio ....................................... 57 


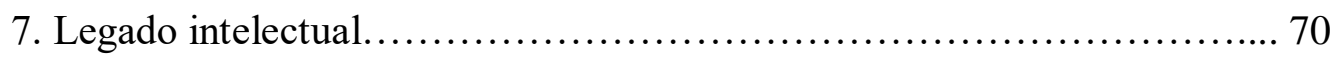

8. José Ferrater Mora en la filosofía española................................ 87

CAPÍTULO 2: LA FILOSOFÍA COMO ONTOLOGÍA........................... 104

9. Visión de Ferrater Mora acerca de la ontología............................. 105

10. Reduccionismo, lógica y realidad...................................... 118

10.1. Reduccionismo............................................ 118

10.2. Lógica y realidad................................................... 125

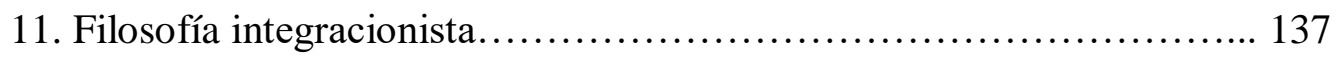

11.1. El método ................................... 137

11.2. La delimitación ontológica de lo real y la ontología de la doble dirección. 147

11.3. Una lectura a El ser y la muerte. Bosquejo de filosofía integracionista. 155

\section{CAPÍTULO 3: LA ONTOLOGÍA DE LO EXISTENCIAL EN JOSE FERRATER} MORA

12. El existencialismo y la filosofía existencial en José Ferrater Mora. 171

13. Tanatología y Existencia en Ferrater Mora.................................... 188

13.1. Muerte e inmortalidad: la ilusión integracionista..................... 195

14. Ferrater Mora, existencia y

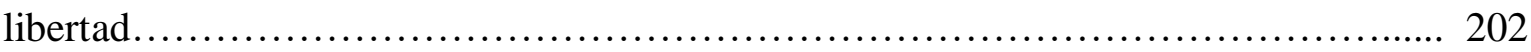

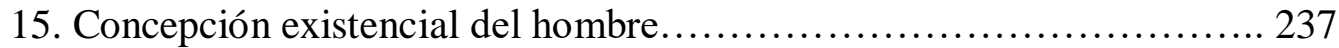

15.1. Lo inorgánico, lo orgánico y lo

humano. 
15.2. Historia y drama de la existencia humana: la muerte que da sentido a la vida. 251

16. CONCLUSIONES

17. BIBLIOGRAFÍA Y RECURSOS ELECTRÓNICOS. 265

18. ANEXOS 274

- Anexo 1: Cátedra de Ferrater Mora de pensamiento contemporáneo. Pág 274.

- Anexo 2: Publicaciones acerca de la vida y obra de José Ferrater Mora. Pág 277.

- Anexo 3: Reconocimientos, premios y condecoraciones otorgadas a J. F. Mora Pág 292.

- Anexo 4: Materiales hemerográficos acerca de José Ferrater Mora. Pág 299. 


\section{ÍNDICE DE ILUSTRACIONES.}

Pág.

Ilustración 1: Sören Kierkegaard................................................. 17

Ilustración 2: Jean-Paul Sartre.................................................... 18

Ilustración 3: Miguel de Unamuno................................................ 22

Ilustración 4: José Ortega y Gasset............................................. 24

Ilustración 5: José Ferrater Mora................................................. 31

Ilustración 6: José Ferrater Mora y su pasión por el cine................................ 32

Ilustración 7: Dibujo de José Ferrater Mora..................................... 35

Ilustración 8: José Ferrater Mora.............................................. 43

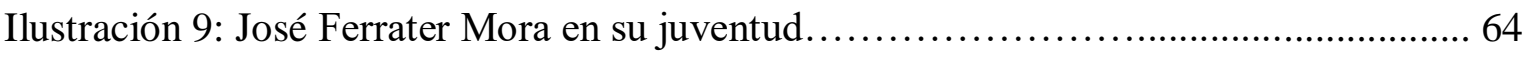

Ilustración 10: Fotografía de José Ferrater Mora con Julián Marías en Soria............. 71

Ilustración 11: José Ferrater Mora y su esposa, Priscilla N. Cohn..................... 72

Ilustración 12: Reseña Entrevista a José Ferrater Mora por parte de Antonio Marquez..... 88

Ilustración 13: Fachada del Bryn Mawr College................................................................ 98

Ilustración 14: Reseña fotográfica de José Ferrater Mora en el programa televisivo: $A$ fondo, de Joaquín Soler Serrano........................................................ 105

Ilustración 15: Reseña fotográfica en artículo: Variaciones de Ferrater Mora. 156

Ilustración 16: José Ferrater Mora Premio Príncipe de Asturias de Comunicación y

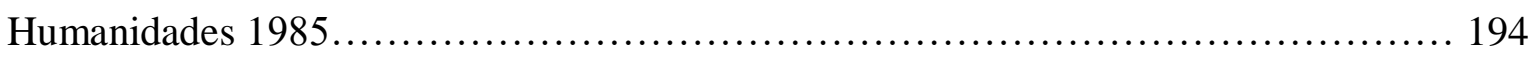

Ilustración 17: Wilhelm Dilthey........................................... 258

Ilustración 18: Entrega a José Ferrater Mora del premio Príncipe de Asturias en 1985 por su gran aporte a las ciencias humanísticas.

Ilustración 19: Medallas distinciones Doctor Honoris Causa otorgadas a José Ferrater Mora por la Universidad de Barcelona 1979............................................ 293

Ilustración 20: Cruz de Isabel La Católica otorgada a José Ferrater Mora en 1982 ....... 294 
Ilustración 21: Gran Cruz de Alfonso el Sabio otorgada a José Ferrater Mora en 1984... 294 Ilustración 22: Reconocimiento póstumo a José Ferrater Mora por la Universidad Santiago

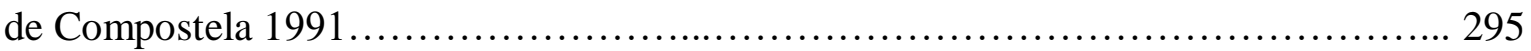

Ilustración 23: Reseña periodística Diario de Girona Miércoles, 13 de noviembre de 2002

Ilustración 24: Artículo sobre José Ferrater Mora en la Revista Destino (Año 1952) 300

Ilustración 25: Portada Diario El País correspondiente al 31 de enero de 1991, donde se anuncia el fallecimiento de José Ferrater Mora 301

Ilustración 26: Reseña de prensa acerca del fallecimiento de José Ferrater Mora.... 302 Ilustración 27: Reseña de prensa 2 acerca del fallecimiento de José Ferrater Mora 303 


\section{ÍNDICE DE ANEXOS}

Pág.

Anexo 1: Cátedra de Ferrater Mora de pensamiento contemporáneo...................... 274

Anexo 2: Publicaciones acerca de la vida y obra de José Ferrater Mora........................... 277

Anexo 3: Reconocimientos, premios y condecoraciones otorgadas a José Ferrater Mora................................................................... 292

Anexo 4: Materiales hemerográficos acerca de José Ferrater Mora...................... 299 


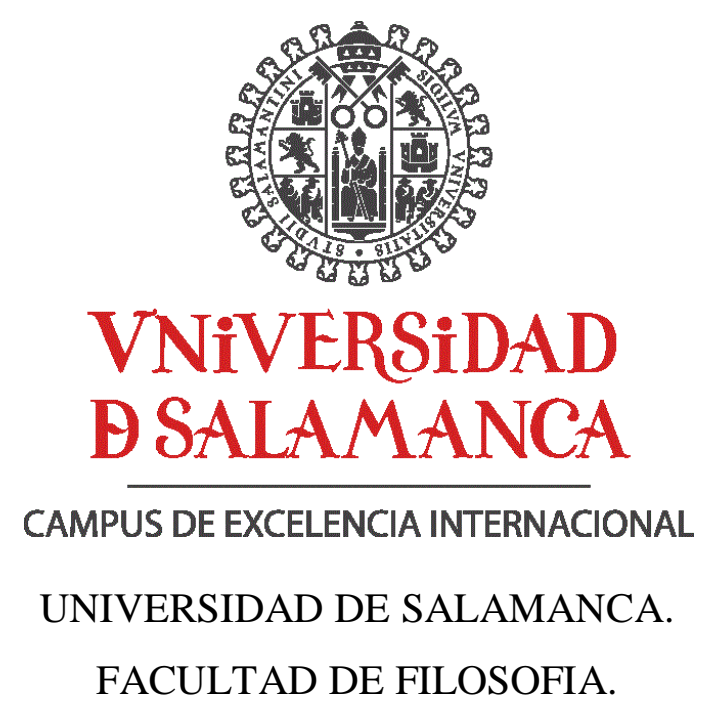

“ELEMENTOS EXISTENCIALES EN LA FILOSOFÍA DE JOSÉ FERRATER MORA”.

Autora: Dña Ana Josefa Rey de la Fuente.

Directora: Dra. Dña María del Carmen Paredes Martín.

Tutor: Dr. D.Francisco T. Baciero Ruiz.

Salamanca, Junio 2017.

Línea de investigación: Filosofía.

Palabras Claves: Filosofía, Existencialismo, José Ferrater Mora, Integracionismo, El Ser.

\section{RESUMEN.}

El ser, la existencia y la filosofía existencial son los diversos enfoques que se han engendrado a lo largo del devenir histórico filosófico, estos buscan sustentar la base pragmática de esta corriente, la cual no se encasilla pero que lucha junto a seguidores y detractores por adquirir y homogenizar un significado conceptual para ubicarla en el entorno académico enmarcado en las ciencias sociales. Por lo tanto, estos serán los escenarios donde se centre la presente investigación, la cual busca detectar la presencia o no de elementos característicos de la filosofía existencial y el existencialismo en el desarrollo filosófico de José Ferrater Mora, quien ha sido calificado como el más destacado filósofo catalán del siglo XX, y que en palabras de Carlos Nieto Blanco, uno de los más febriles investigadores acerca de su vida y obra, considera que representa uno de los escasos y grandes hitos del pensamiento español del siglo pasado. Asimismo, esta investigación tendrá como propósito conectar la filosofía existencial o filosofía de la existencia con una de sus expresiones más prolíficas, el Existencialismo con el Integracionismo. Aunque José Ferrater Mora no tuvo interés en convertir este último en un movimiento filosófico, sí representó su propio sistema y el método que rigió gran parte de su desarrollo escritural. 


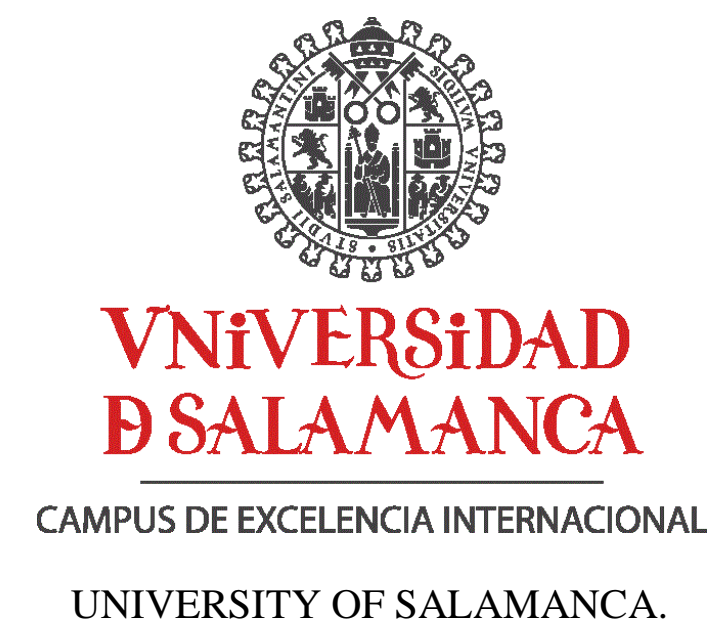

"EXISTENTIAL ELEMENTS IN THE PHILOSOPHY OF JOSÉ FERRATER MORA".

Director: Dra. Dña María del Carmen Paredes Martín.

Tutor : Dr D. Francisco T. Baciero Ruiz.

Author: Dña Ana Josefa Rey de la Fuente.

2017

Research Line: Philosophy.

Keywords: Philosophy, Existentialism, José Ferrater Mora, Integrationism, Being.

\section{ABSTRACT (Ilustrativo).}

Being, existence and the existence philosophy are the various approaches that have been engendered throughout the historical philosophical evolution, these seek to support the pragmatic basis of this current, which don't pigeonhole but fights along with followers and detractors for acquiring and homogenizing a conceptual meaning to place it in the academic environment in the social sciences. Therefore, these will be the scenarios where the present research focuses on seek to detect the presence or not of characteristic elements of Existentialism in the philosophical development of José Ferrater Mora, who has been described as the most outstanding Catalan philosopher of the twentieth century, and in words of Carlos Nieto Blanco, one of the most feverish investigators about his life and work, he considers that he represents one of the greatest landmarks of Spanish thought of the last century. Furthermore, this research will connect the Existentialism with Integrationism. Although José Ferrater Mora was not interested to convert the latter into a philosophical movement, he did represent his own system and the method that governed most of its scriptural development. 


\title{
SECCIÓN INTRODUCTORIA.
}

1. Introducción.

\author{
El existencialismo sostiene \\ relaciones muy matizadas con \\ otras direcciones contemporáneas \\ José Ferrater Mora \\ El existencialismo está tan \\ integrado en nuestra cultura \\ que ni siquiera lo detectamos
}

Sarah Bakewell

Aun cuando la existencia del ser, ha sido objeto de estudio desde muchos enfoques a lo largo del devenir histórico del pensamiento filosófico, la historia de la filosofía coincide en que es, sólo a partir de poco más de un siglo, cuando adquiere un significado conceptual preciso, toma forma homogénea y se empieza a manejar para la designación de una corriente filosófica novedosa, originada en el siglo XIX.

Los llamados filósofos existenciales concentraron sus esfuerzos en el análisis y observación de la llamada condición humana, englobando en dicha categoría un amplio grupo de temas, donde se aprecian, entre los de mayor difusión: la libertad y la responsabilidad como individuo, sin olvidar otros tópicos como la reflexión alrededor de las emociones, así como también, el cuestionamiento insistente sobre el significado de la vida.

La realidad es que se alza como una tarea ardua el propósito de dar una definición precisa a la filosofía existencial y por ende al existencialismo. El mismo José Ferrater Mora, en la entrada que dedica a este término en su Diccionario de filosofía, comienza reconociendo que: por el abusado uso del vocablo apenas significa nada, pues se han calificado de existencialistas, no solamente ciertas tendencias filosóficas contemporáneas, sino muchas filosofías del pasado, tanto antiguas como modernas. (Ferrater Mora, 2004: 1174).

Como es claro, la filosofía en general trata sobre la vida, aquello que va desde las cosas llamadas "grandes" a cosas "pequeñas" que de acuerdo a la visión del pensador, sabio o filósofo, pueden tener una importancia vital. Del macrocosmos al microcosmos, donde la vida es el tema primordial de toda filosofía. La existencia del ser es precisamente 
una de las cuestiones del pensamiento que ha recibido mayor tratamiento desde lo que algunos consideran: la génesis de la reflexión filosófica hasta la actualidad.

En efecto, algunos historiadores de la filosofía han denominado existencialistas a los filósofos jonios y a los estoicos, incluso a los agustinianos y, desde luego, a los empiristas modernos. No faltan tampoco intérpretes del pensamiento medieval que oponen el supuesto existencialismo de Santo Tomás de Aquino al esencialismo de Avicena ${ }^{1}$.

La noción de existencialismo y la filosofía existencial entonces puede designar y abarcar, diversas corrientes de pensamiento. Incluso aquellas corrientes y sistemas filosóficos encontrados o adversos. Considérese así mismo que algunos autores han hecho del término una especie de "comodín" a la hora de caracterizar una determinada obra o idea filosófica.

La palabra o vocablo existencia tanto en la filosofía clásica como en la contemporánea está en boca de muchos. En diversos análisis y sistemas filosóficos, es un fenómeno que incluso ha sido expuesto en la filosofía y el pensamiento posmoderno. De hecho, la posmodernidad también abarca tópicos de carácter existencial y sin duda la existencia y lo existencial siempre serán un tema que traten y seguirán tratando los pensadores de vanguardia, esos que hacen filosofía al margen de las afirmaciones de muchos especialistas acerca de que el existencialismo o la filosofía existencial pasó a segundo plano y quedo en el pasado, y de aquellos que incluso se atreven a pensar que ha muerto, no solo la filosofía existencial, sino la filosofía en general.

Otros academicistas suelen colocar dicha etiqueta, de forma indiscriminada sobre aquello que se ubica relacionado con vocablos como: "existir", "existencia", "existencial", "esencia", "ente", "ser"; para desde allí partir hacia los "ismos" de una manera somera, sin un fundamento sólido que puede dirigirse más allá de lo sustancial; sin motivaciones ni el rigor de la ciencia, calificar o colocar etiquetas en la filosofía o en sistemas filosóficos o en el simple desarrollo de narrativas filosóficas que traten tópicos o contengan palabras que usualmente estén incorporadas en el lenguaje de filósofos existencialistas o que hayan desarrollado una filosofía existencial que muchas veces adolece de una argumentada

\footnotetext{
${ }^{1}$ Emmanuel Mounier, en su conocida obra Introducción a los existencialismos (1973), presenta gráficamente todas las modalidades del existencialismo mediante el dibujo de un árbol, cuyas raíces son Sócrates, los estoicos y San Agustín, el tronco los ocupa Sören Kierkegaard y las ramas principales Martin Heidegger, Karl Jaspers, Jean-Paul Sartre, Gabriel Marcel y la fenomenología y el mismo personalismo existencial fundado por él.
} 
ontología y epistemología que al menos sostenga las columnas de una idea, tesis o hipótesis. O argumentos que carecen de solidez científica y un adecuado uso del logos.

Como ya se ha hecho mención, son muchos los enfoques y rasgos que caracterizan esas ideas y el conjunto de visiones que se tiene de la existencia, lo existencial y la esencia, que conlleva a "lo esencial". De allí surge la idea de analizar el existencialismo y la filosofía existencial, inicialmente desde un punto de partida conceptual, a riesgo de que los conceptos pudieran tener otros orígenes distintos al uso que ciertos pensadores le atribuyen, esto es precisamente lo que constituye, en algunos casos, una génesis o comienzo para el análisis de una determinada corriente o sistema filosófico.

Si bien pudiera afirmarse que no todo filósofo que trate el tema existencial es existencialista, todo existencialista indefectiblemente trata el tema existencial. Ser existencialista equivale a hacer filosofía existencial o filosofía de la existencia. En este aspecto, a pesar de que el existencialismo como corriente o movimiento filosófico es más prolífico, que la cantidad de obras escritas en torno al existencialismo es muy densa, el tema existencial o filosofía de la existencia puede englobar más cosas, porque no se limita a una corriente y en sí misma la filosofía existencial no constituye una corriente o movimiento filosófico, sino más bien es la filosofía que se hace en torno a la existencia sin que ello implique que se hagan categorías o caracterizaciones específicas.

La mejor forma de combatir este abuso terminológico será entonces limitar la aplicación del "existencialismo" a una corriente filosófica que, si se hace caso al juicio equilibrado de José Ferrater Mora, "se remonta solamente a Kierkegaard, el cual lanzó por primera vez el grito de combate: contra la filosofía especulativa [principalmente de Hegel] la filosofía existencial” (Ferrater Mora, 2004: 1175).

Adecuadamente, José Ferrater Mora cuando analiza lo que está plasmado en su obra académica bajo el concepto de existencialismo, también aborda de una manera significativa el concepto de existencia y también agrega un concepto de filosofía de la existencia o filosofía existencial, del cual se hará una pertinente lectura en posterior desarrollo del presente trabajo de grado.

Con referencia al existencialismo se ha hecho hincapié, y aún es necesario seguir haciéndolo, que el mismo no se trata de una escuela filosófica uniforme ni reglamentada, por el contrario se observa que sus partidarios se identifican especialmente por sus marcadas reacciones contra la llamada filosofía tradicional. 
Eso se verá aplicado en el caso del existencialismo, término que, aunque designa muchas ideas y agrupa sistemas filosóficos de algunos pensadores que se autodenominan "existencialistas", suele aplicarse también a algunos pensadores, como Martin Heidegger, quien no se reconoce como tal. El filósofo alemán hizo más referencia a la filosofía de la existencia (Existenphilosophie).

Incluso aquellos que siendo identificados en una época de su obra temprana como existencialistas, y consideran que, a lo largo del tiempo, han superado el existencialismo, y hasta aquellos que se atreven, como ya se ha hecho mención, a afirmar que el existencialismo ha muerto.

Así es como se encuentra que esta filosofía existencial, opuesta al sistema hegeliano, se caracteriza, en primer lugar: por la inclusión del mismo sujeto en el pensar que no pretende ya contemplar o reflejar objetivamente la realidad, sino penetrar en el ser mismo de la existencia. Pero no la existencia de cualquier realidad exterior, sino la misma fluyente, finita y efímera existencia del ser mismo del hombre, que no es un objeto ni una sustancia, sino un ser que se constituye a sí mismo a partir de su misma comprensión.

Por tanto, el existencialismo es un modo de entender la existencia como existencia humana, que constituye el punto de apoyo de este filosofar, que resulta, por ello, muy difícil de definir por ese componente subjetivo y, en ocasiones, hasta irracional, que caracteriza con frecuencia las reflexiones de filósofos como Martin Heidegger o Jean-Paul Sartre, por mencionar tal vez a las dos grandes figuras de esta corriente que describe fenomenológicamente la existencia humana, como una forma de ser finita, libre, comprometida con la situación, abocada a la muerte y a la ineludible tarea de construir su propia vida auténtica.

Ciertamente en la actualidad, se consideran tres tipologías de posibles "escuelas" adscritas al existencialismo, denominadas con frecuencia como: existencialismo cristiano, existencialismo agnóstico y existencialismo ateo.

Para algunos especialistas es de vital importancia insistir y alcanzar un acuerdo general acerca de la definición de existencialismo, ya que, a su juicio, nunca se logrado tal objetivo. Con frecuencia la expresión es vista e inclusive aceptada, sólo por su utilidad terminológica, es decir: como una fórmula eficaz en su aplicación histórica a un pasado filosófico reciente, en el que destacan ilustres figuras de la filosofía alemana y francesa principalmente. 
Tal vez se podría describir el existencialismo, aceptando la caracterización extraída del Diccionario filosófico autoría de André Comte-Sponville, como:

"El hombre sólo se distingue por la conciencia que tiene de él, y que lo separa de ese afuera que lo hace existir, y de sí mismo. Por ese motivo, él existe, en el sentido esta vez heideggeriano o existencialista del término, siempre fuera de sí, siempre por delante de sí mismo y de todo, siempre arrojado (en el mundo) y proyectándose (en el porvenir), siempre diferente de lo que es, siempre libre, siempre abocado a la inquietud o la angustia, siempre orientado hacia la muerte o la nada. Está claro que estos dos sentidos, por muy diferentes que sean, pueden tomarse conjuntamente. Existir es encontrarse fuera: es depender o separase". (Comte- Sponville, 2003: 213).

Aunque es pertinente reconocer que no faltan autores que niegan tal conjunto de doctrinas comunes y no perciben entre los filósofos considerados existencialistas más que un punto de partida común, que es el análisis de la existencia o cierto fenómeno que correspondería a una filosofía de la existencia, y un modo semejante de afrontar esa primacía de la existencia sobre la esencia, que es el rasgo que enfrenta a estos pensadores alemanes y franceses al extremo esencialismo de la filosofía tradicional.

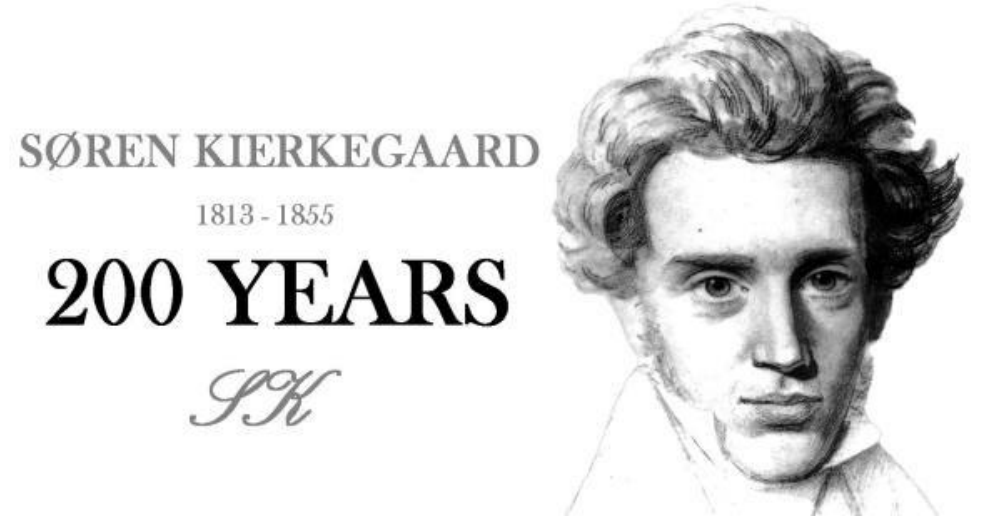

Ilustración 1: Sören Kierkegaard

(Fuente: Citado por Jason Gorroncy. Post: Encuentro de Aquel que ha establecido parentesco con nosotros en el tiempo: Celebrando. 2013. Tomado de: https://jasongoroncy.com/2013/05/)

Ahora bien, estando en el terreno del reconocimiento del llamado existencialismo, habitualmente se considera que éste se produjo primariamente con la obra del filósofo danés Sören Kierkegaard, pero para algunos especialistas, ciertamente fue el filósofo francés Jean-Paul Sartre, el primer pensador destacado en acuñar el término en cuestión, con el cual detalló sus propias ideas filosóficas.

La célebre idea de que: ciertamente, los existencialistas tienen en común la principal doctrina de la posición del hombre en el mundo y no en el ego encerrado en sí mismo, es 
decir, asumiendo que la existencia precede a la esencia ${ }^{2}$ (Copleston, 2003: 134), propuesta de Jean-Paul Sartre; lo que significa que la atención más representativa para el individuo es el hecho de reconocerse o ser reconocido por su ser, un ser consciente que actúa de manera independiente y responsable, identificado en la existencia, en lugar de ser rotulado con roles, estereotipos, definiciones u otras categorías proyectadas que se concuerdan al individuo como la esencia. Todo ello dejando por sentado que la vida real de la persona es componente macro de lo que podría denominarse como su verdadera esencia (Marías, 1998: 424).

\section{JEAN-PAUL SARTRE (1905 - 1980)}

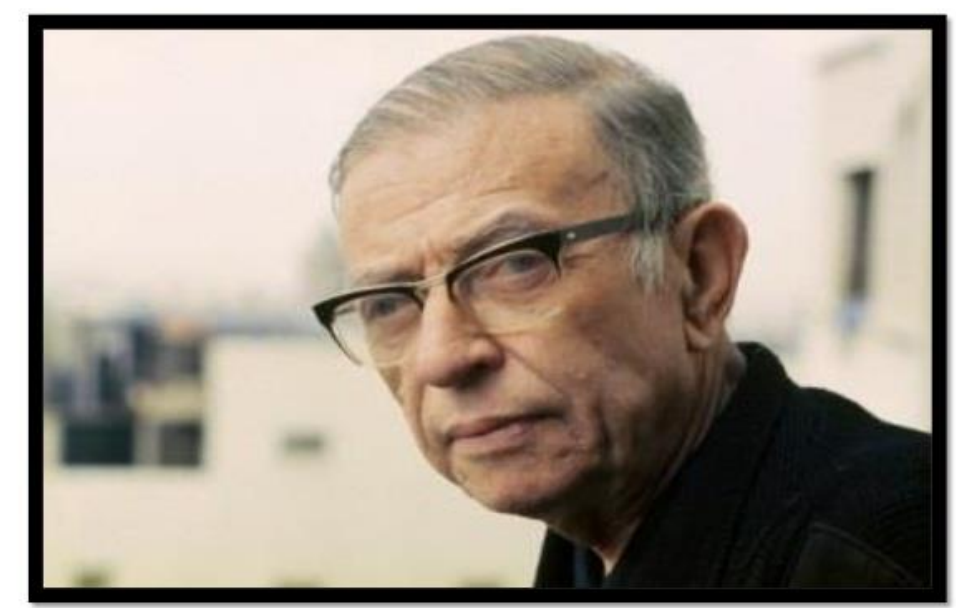

Ilustración 2: Jean-Paul Sartre

(Fuente: Citado por Juliana Corvino de Araújo. Filosofía contemporánea - Jean Paul Sartre. 2014.

Tomado de: https://es.slideshare.net/Jucorvino/filosofia-contempornea-42525129/8?smtNoRedir=1)

Jean-Paul Sartre al autodenominarse un filósofo existencialista, da un carácter de identidad al existencialismo. Quizás es Jean-Paul Sartre, el pensador al que más relacionan con el existencialismo, por la defensa que realizó en torno a esta corriente filosófica y en la cual se atrevió a nombrar otros pensadores más o menos contemporáneos a él dentro de este ámbito filosófico.

Es muy conocida en el universo de la filosofía su conferencia El existencialismo es un humanismo, donde el filósofo francés sostiene:

\footnotetext{
${ }^{2}$ Frederick Charles Copleston en Logical Positivism and Existentialism, sostiene que: "for the existentialists certainly have this in common that for them the primary datum is man-in-the world and not the self-enclosed ego" (2003: 134).
} 
"El existencialismo es un humanismo. Muchos podrán extrañarse de que se hable aquí de humanismo. Trataremos de ver en qué sentido lo entendemos. En todo caso, lo que podemos decir desde el principio es que entendemos por existencialismo una doctrina que hace posible la vida humana y que, por otra parte, declara que toda verdad y toda acción implica un medio y una subjetividad humana" (Sartre, 2006: 22).

La visión sartreana del existencialismo promueve la libertad humana y social. Una libertad a la que el hombre está condenado, porque además tiene la capacidad para desarrollar sus potencialidades y oponerse a las adversidades. El existencialismo de JeanPaul Sartre por lo tanto, puede vislumbrarse como un existencialismo subversivo o rebelde. El existencialismo sartreano es militante, en sí mismo constituye un existencialismo que busca ser político y no limitarse a lo académico, sino que trascienda fronteras. En las siguientes palabras del filósofo francés, en la ya mencionada conferencia, se observan las posturas adversas al existencialismo a las que él enfrenta:

"Conocemos los lugares comunes que se pueden utilizar en este punto y que muestran siempre la misma cosa: no hay que luchar contra los poderes establecidos, no hay que luchar contra la fuerza, no hay que pretender salir de la propia condición, toda acción que no se inserta en una tradición es romanticismo, toda tentativa que no se apoya en una experiencia probada está condenada al fracaso" (Sartre, 2006: 23-24).

Jean-Paul Sartre desde su visión existencialista se opone a toda fuerza que quiera someter a límites las acciones del hombre. Su existencialismo es una crítica a todo lo impuesto, a las fuerzas fácticas que gobiernan la humanidad. En virtud de lo expuesto, Jean-Paul Sartre habla de la responsabilidad del existencialismo en cada uno de los hombres, desde el ser hacia los seres como lo proclama:

"Así el primer paso del existencialismo es poner a todo hombre en posesión de lo que es, y asentar sobre él la responsabilidad total de su existencia. Y cuando decimos que el hombre es responsable de sí mismo, no queremos decir que el hombre es responsable de su estricta individualidad, sino que es responsable de todos los hombres" (Sartre, 2006: 29-30).

Pueden verse en Jean-Paul Sartre rasgos característicos que lo conectan con el pensamiento existencial de Sören Kierkegaard, que confronta y rechaza abiertamente a las morales y éticas promulgadas por las doctrinas cercanas al empirismo, racionalismo y otras corrientes filiales a los absolutismos. De hecho, en la ya aludida conferencia, hace una conexión con la visión del filósofo danés, al destacar que: "Aun cuando la angustia se 
enmascara, aparece. Es esta angustia la que Kierkegaard llamaba la angustia de Abraham" (Sartre, 2006: 32). Con lo cual para Jean-Paul Sartre, la angustia que un alma consciente siente por encontrarse condenada a ser libre, significa tener, a cada momento, la absoluta responsabilidad de renovarse.

En contra de las afirmaciones de la tradición filosófica, quienes sostenían que el bien ético más elevado es semejante para todos, Sören Kierkegaard afirmaba que el bien más alto para el individuo es encontrar su propia vocación. Él escribió en su diario: "Debo encontrar una verdad que sea verdadera para mí... la idea por la que pueda vivir o morir" (Dru, 1938). El pensamiento que sustenta este razonamiento, es que uno debe escoger su propio camino sin la ayuda de normas o criterios universales u objetivos, a ello es lo que se le ha llamado individualismo moral. En contraposición de la visión tradicional que concibe que el juicio moral involucre, o al menos debería involucrar, una norma objetiva de corrección o incorrección.

El filósofo danés sostiene que no es posible fundamentar una base objetiva o racional en las decisiones morales. La insuperable base de una filosofía con significado es el individuo existente. La filosofía no tiene que ver con una contemplación equitativa, es decir, objetiva, del mundo, ni tampoco en función de penetrar la verdad. Para Kierkegaard verdad y experiencia están indisolublemente combinadas y hay que desatender la representación de que la filosofía es una especie de ciencia exacta y pura.

A la postre, los denominados existencialistas seguirán a Kierkegaard al acentuar la importancia del quehacer individual al concluir sobre cuestiones de moralidad y de verdad. La experiencia particular y el actuar, en consonancia con convencimientos propios, son cardinales para alcanzar a la verdad.

El entendimiento que de una situación adquiere el agente involucrado será siempre superior al de un observador desinteresado. Los existencialistas dan énfasis en la perspectiva subjetiva, acto que estimula que alcancen a ser llamados, en cierto sentido, subjetivistas, y que concibe que sean considerados pensadores asistemáticos. Hecho que se contraponen a la existencia de principios racionales, objetivos y generalmente autorizados, como los que había hecho formulación el filósofo prusiano Immanuel Kant.

Ahora bien, para los entendidos, en cierto sentido, los existencialistas, partiendo de Kierkegaard, son de algún modo también irracionalistas, ello no a causa de que nieguen el 
papel de la tendencia filosófica racional, sino puesto que conceptúan que las cosas más trascendentes de la existencia no son comprensibles a la razón o a la ciencia.

Tal vez podría decirse que el existencialismo representa una forma extrema de la filosofía vitalista, que constituye uno de sus indudables antecedentes. Tanto Wilhelm Dilthey, como Friedrich Nietzsche y Henri Bergson muestran una especial aversión hacia toda filosofía teórica, objetiva y científica, como expresión de una inclinación por la razón alejada de la vida.

Es necesario recalcar que el existencialismo rechaza el carácter sistemático y racionalista de la filosofía moderna, desde René Descartes hasta Georg Wilhelm Friedrich Hegel, en pro de proponer un pensamiento al servicio de la existencia, una visión íntima de la vida del propio filósofo, sin preocuparse de la dimensión social de esa vida propia, concreta e individual.

Aquel que fuera un pensamiento iniciado por Aristóteles, fue concretado luego por G. W. F. Hegel quien señaló en su postulado Fenomenología del Espíritu, que:

"Si es cierto que el embrión es en sí un ser humano, no lo es, sin embargo, para sí; para sí el ser humano sólo lo es en cuanto razón cultivada que se ha hecho a sí misma lo que es en sí. En esto y solamente en esto reside su realidad" (Hegel, 1999: 17).

Por su parte Jean-Paul Sartre aseguró que los seres humanos primero existen y luego adquieren esencia; es decir, sólo existen y, mientras viven, van aprendiendo de los demás humanos que han inventado cosas abstractas. Desde el mismo Dios hasta la existencia de una esencia humana previa, el humano, considera Jean-Paul Sartre, se libera en cuanto se realiza libremente y esa es su esencia, su esencia parte desde sí para sí mismo.

El individuo entonces es libre y absolutamente responsable de sus actos, según promulga el existencialismo. Estimulando en el ser humano la creación reflexiva de una ética de la responsabilidad individual, ajena a cualquier otro entramado de creencias exteriores a sí mismo.

Esta nueva mirada filosófica justifica rasgos irracionalistas, pues la vida y la existencia son inaccesibles a la razón y a la lógica, como afirma reiteradamente Miguel de 
Unamuno, considerado por algunos intérpretes como un precursor del existencialismo ${ }^{3}$, quien postula que: "por cualquier lado que la cosa se mire, siempre resulta que la razón se pone enfrente de nuestro anhelo de inmortalidad personal, y nos la contradice. Y es que en rigor la razón es enemiga de la vida" (1989: 535) o, aún con mayor claridad: "Todo lo vital es irracional, y todo lo racional es antivital, porque la razón es esencialmente escéptica" (1958: 810).

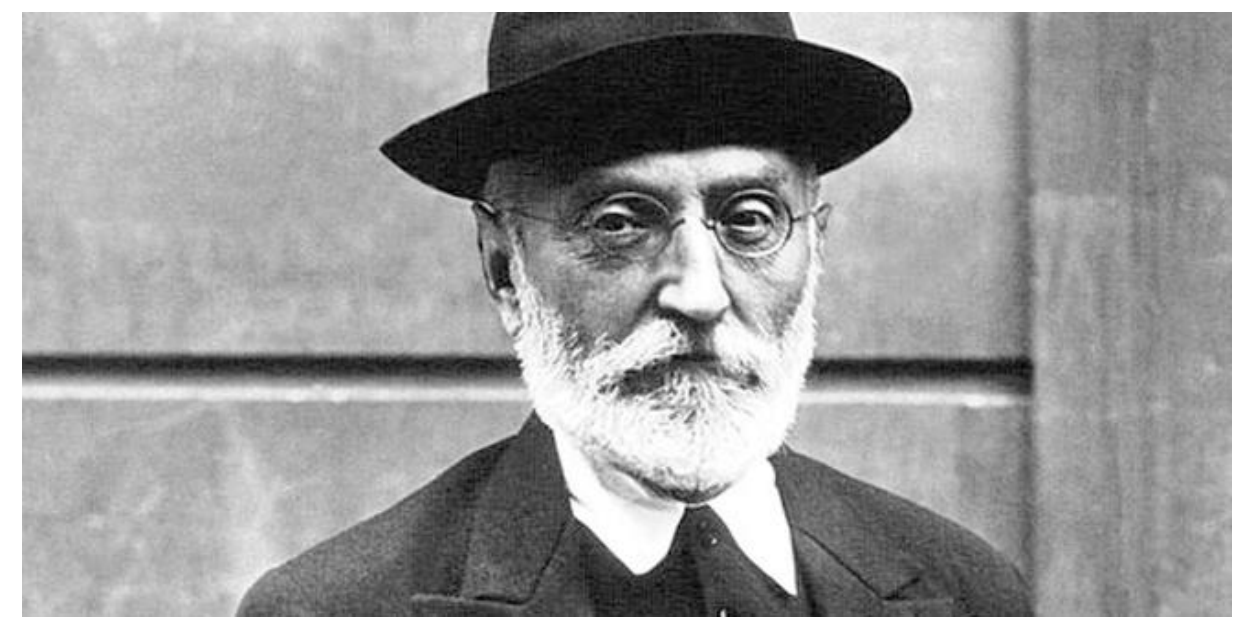

Ilustración 3: Miguel de Unamuno

(Fuente: Agence de presse Meurisse via Wikimedia Commons. Citado por Chema de Aquino Post: Unamuno y su nivel de inglés. Tomado de: https://siempreconectado.es/unamuno-nivel-ingles/)

Y, en este sentido, se expresa igualmente Karl Jaspers, afirmando que la existencia es inaccesible a la razón, sumiendo a ésta en una nube de dudas, pues la existencia es lo que el sujeto puede ser, pero no ver ni saber. Y señala que la: "Filosofía existencial descubre la insuficiencia del pensamiento en un sentido más tajante: en el sentido de que cualquier intento de esclarecimiento racional desemboca en contradicciones insolubles, de las que queda prisionero el pensamiento en un inútil y continuo forcejeo" (1932).

Un perfil vinculado a la experiencia individual, ha venido imputándosele a la corriente existencialista, enlazada a las contradicciones, trastornos, incongruencias e incluso la estupidez de hombres y mujeres. Esta corriente del pensamiento formula discusiones, a la vez que permanece activa proponiendo soluciones a las problemáticas de mayor inherencia a la condición humana; tal como lo absurdo del vivir, las insignificaciones del ser, como los dilemas de las guerras; el tiempo; la libertad, bien sea

\footnotetext{
${ }^{3}$ Para mayores referencias. Véase González Caminero, N., "Miguel de Unamuno: precursor del existencialismo", en Pensamiento, 1949. Y un estudio más profundo y reciente es el de Ocampo Fruto, D., "Lo trágico como condición existencial del hombre en Schopenhauer y Unamuno", en Logos, 2015-2016.
} 
física o metafísica; la relación Dios-Ser Humano; ; el ateísmo, la naturaleza del ser; la dualidad vida y muerte, entre tantos otros temas.

Indaga entonces el existencialismo en revelar lo que circunda a la humanidad, elaborando una descripción minuciosa del medio material y abstracto en que se despliega el individuo, existente, para que éste adquiera una comprensión propia y permita otorgar sentido o encontrar una justificación para su existencia. Pese a los ataques procedentes con mayor ímpetu de la religiosidad cristiana, el existencialismo busca justificación para la existencia humana.

Por este carácter asistemático, el existencialismo no pretende convertirse en un sistema objetivo y de validez universal, sino en un "llamamiento" sobre el problema de la existencia. Sören Kierkegaard subrayó la unicidad de la existencia concreta y, sobre todo, la irrepetibilidad de la existencia de cada individuo en su situación vital.

Su voz solitaria fue la que llevó a la filosofía europea a descubrir la existencia singular y finita como el objeto primero de la filosofía. Es el primer momento del existencialismo, que el profesor Pietro Prini (1957) ha denominado como "existencialismo romántico" ${ }^{4}$ al que seguiría el existencialismo metafísico de Martin Heidegger, Karl Jaspers y Gabriel Marcel y que culminaría en el existencialismo humanista de Jean-Paul Sartre.

Precisamente Jean-Paul Sartre, es quien definitivamente, establece uno de los pocos postulados que comparten todos los pensadores de esta corriente, el ya referido a que la existencia precede a la esencia, afirmando lo siguiente:

"El existencialismo ateo que yo represento es más coherente. Declara que si Dios no existe, hay por lo menos un ser en el que la existencia precede a la esencia, un ser que existe antes de poder ser definido por ningún concepto, y que este ser es el hombre o, como dice Heidegger, la realidad humana" (Sartre, 2006: 28 ).

\footnotetext{
${ }^{4}$ Según Pietro Prini: "Se puede hablar, en efecto, de una edad del existencialismo romántico, desde Kierkegaard a Kafka, de una edad del existencialismo metafísico, con Heidegger, Marcel, Jaspers, Berdjaef y otros, y, en fin, de una edad del existencialismo humanístico, representada por Sartre y su escuela, y en Italia especialmente por Abbagnano" (1957: 4).
} 
He aquí una nota original del existencialismo: la única existencia es la humana. Y el hombre es sólo esa existencia, que es posibilidad, libertad y proyecto. Frente a la naturaleza estática de las cosas externas al hombre, como entes acabados y definitivos, el hombre, como dirá José Ortega y Gasset (1989), otro de los pensadores afines al existencialismo, no tiene naturaleza, sino historia, no es un ser, una res, sino un gerundio, un siendo. Así entendida, la existencia es pura facticidad, es quehacer sin determinación esencial previa alguna.

José Ortega y Gasset, asociado en primer orden al objetivismo y luego al perspectivismo, resumió su filosofía en la tesis: "yo soy yo y mi circunstancia" (1914), expuesta en Meditaciones del Quijote, allí consideró que la vida es la realidad radical, la relación entre el yo y las circunstancias, el ámbito en el que se hace presente todo, es el experimentar la realidad, una conjunción de experiencias, lo que se conoce en lengua alemana como Erlebnisse, en las que cada uno se relaciona con el mundo.

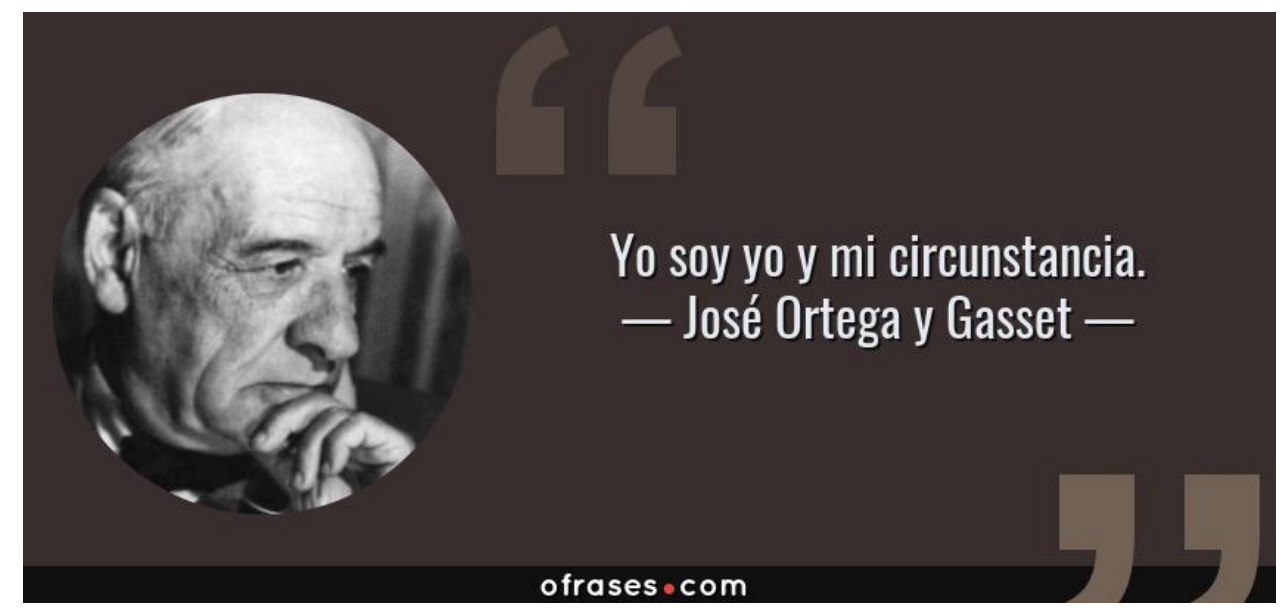

Ilustración 4: José Ortega y Gasset (Fuente: ofrases.com Tomado de: http://www.ofrases.com/frase/1787)

La intuición es la vivencia en la que está presente la evidencia y es sobre las evidencias que descansa nuestro conocimiento. "La vida es una actividad que se ejecuta hacia adelante, y el presente o el pasado se descubren después, en relación con ese futuro”, palabras de José Ortega y Gasset citadas por Roberto Cruz F. en la obra El hombre pregunta (1994).

Sin duda ha sido Martin Heidegger, a pesar de rechazar su adscripción al existencialismo, quien ha dado una fundamentación ontológica al análisis existencial. La cuestión esencial de su primera gran obra, Ser y tiempo (1927), es la pregunta por el sentido del ser, una cuestión que, a juicio de Martín Heidegger, ha sido descuidada o mal 
planteada por la filosofía, desde sus orígenes. La metafísica, desde los griegos, se ha preguntado por distintos entes concretos, pero se ha olvidado del ser. Por ello, la metafísica ha de ser sustituida por una ontología fundamental que pueda descubrir el sentido del ser, del que se tiene un cierta precomprensión vaga e insuficiente.

Y el ente que debe ser interrogado es el Dasein, el ser que tiene la posibilidad de preguntar, de comprender, de revelar y manifestar el ser, porque tiene prioridad óntica y ontológica sobre los demás seres, ya que su ser está determinado por la existencia. Lo que significa, por tanto, que el hombre es el único ente cuyo modo de ser es la existencia, cuyo análisis ha de ser el primer paso para la determinación del sentido del ser en cuanto tal. Un análisis existencial que ha ser fenomenológico, porque la esencia de la fenomenología consiste en descubrir el fenómeno, en intuir lo que se manifiesta y tal como se manifiesta. Es, por tanto, una ontología universal y fenomenológica.

Y lo primero que descubre el análisis de la existencia que lleva a cabo Martin Heidegger es que el Dasein es existencia, posibilidad. Es ser en el mundo, pues el mundo está inserto en el ámbito del Dasein, pues las cosas se muestran al hombre como seres a la mano, utensilios u objetos cuyo sentido radica en el existente humano, mientras los otros seres existentes se muestran como seres que encuentran su sentido en el mundo solidario de los seres humanos. Esto supone la radical abertura del hombre al mundo y a los otros, aunque radicalmente el hombre es un ser que se halla arrojado, proyectado hacia un fin y es, por ello, un ser para la muerte, pues la muerte se le presenta como la única posibilidad.

Con posterioridad, el resto de su obra, que seguirá al primer tratado mencionado, publicado en el año 1927, se ocupará de otros asuntos en los que ya no se transparenta el asunto existencial. Esta aparente ruptura con el hilo conductor de su primer pensamiento será un hiato en su discurso, que el filósofo no aceptará nunca como tal. Sin embargo, cuantiosos críticos la denominarán: "el segundo Heidegger", el cual da como toda respuesta filosófica final, literalmente, el silencio.

La finitud de la existencia humana produce angustia, cuidado, que revelan la inconsistencia e imposibilidad de la propia existencia, pues la muerte, dice Martin Heidegger, en cuanto posibilidad no inclina al hombre a hacer nada, sino a aceptar la propia nihilidad existencial, su situación de ser arrojado ante un destino inexorable. Un ser carente de libertad para construir su futuro sin determinaciones previas, pues se halla 
proyectado desde el pasado y no cabe más libertad que admitir la necesidad de aceptar su destino.

En buena medida, Jean-Paul Sartre profundiza en este análisis existencial de Martin Heidegger y, en la interpretación de Pietro Prini acerca del existencialismo al humanismo, ya en su novela La náusea (1938), presenta una primera y radical dramatización de la angustia existencial. El hombre es simplemente un ser ahí que es pura contingencia, pura gratuidad, por ello, cuando intenta dar cuenta de su razón de ser se produce la náusea. Y, poco tiempo después, en su larguísima y difícil obra filosófica, El ser y la nada (1943), entenderá este hecho desnudo de la existencia del hombre y de las cosas, el ser en sí, el ser que está lleno de sí mismo, que no puede ser derivado ni de la nada ni de un ser absoluto. Un ser increado, sin razón para existir, sin referencia a otro ser, el ser en sí está de más para la eternidad.

Así se obtiene que la característica principal del existencialismo sea la atención que presta a la existencia concreta, individual y única del hombre, por lo tanto, en el rechazo de la mera especulación abstracta y universal. El tema central de su reflexión es precisamente la existencia del ser humano, en términos de estar fuera, a saber, en el mundo, de vivencia, y en especial de pathos o en todo caso el temple de ánimo, que en palabras de Martin Heidegger sería el ser en el mundo.

Pero el problema de la existencia humana no reside en que el hombre sea gratuita facticidad, un ser semejante a una piedra en un torrente o en una explosión estelar, sino en que es un ser pensante y dotado de conciencia, que no es sino negatividad, no ser aquello que es. Y su existencia no es más que el proyecto de ser para sí, de ejercitar su libertad necesariamente en la construcción de su propia ser. El vértigo y la condena de la libertad impulsan al hombre a chocar con la libertad de los demás seres humanos que se convierten en el infierno. Hay una especie de crueldad originaria que hace imposible la convivencia humana y conduce necesariamente al fracaso. Y si el fracaso es el destino del hombre, éste resulta ser una pasión inútil.

Martin Heidegger en efecto, se caracterizará, según algunos, por su firme pesimismo (Bunge, 2011), pues considera al ser humano como yecto, es decir, arrojado en el mundo; el Dasein se encuentra arrojado a una existencia que le ha sido impuesta, abandonado a la angustia que le revela su mundanidad, el hecho de que puede ser en el mundo y que por consiguiente, ha de morir. 
El final de este negativo análisis existencial es una renuncia radical de la condición humana, una incomprensión de la existencia, que es descrita, en obras teatrales y novelas, como un estado de ceguera frente a los signos racionales del mundo, que oprime al hombre, desgarrado en su soledad hermética. Y el drama de la existencia humana se halla en ese intento constante de la conciencia de escapar a su propia nada. De suerte que la libertad es una propiedad del hombre y constituye a la vez una condena, pues es el inútil esfuerzo por darse a sí mismo una conciencia, un sentido que supere su vacío original. Y, además, no podrá contar con el reconocimiento ni la colaboración de los otros hombres, considerados esclavos e instrumentos de esta necesidad de alcanzar la condición de señor de su conciencia y de su existencia auténtica.

Esta aparente visión negativa de la condición humana no ha llevado a Jean-Paul Sartre a invitar a la inacción o la desesperación, sino que ha pretendido fundar sobre este análisis fenomenológico de existencia, una especie de moral que convertiría el existencialismo en un humanismo, el humanismo por excelencia. Un humanismo que privilegia al hombre frente a Dios y al mundo. Pues, el negar a Dios como ser contradictorio, que sería al mismo tiempo en sí y para sí, suprime el límite máximo de la dignidad humana. Y, al reducir las cosas del mundo a simples entes en sí, carentes de existencia, se exalta la dignidad humana, al convertirse el hombre en el único ser capaz de crear su propia humanidad.

El existencialismo germinará como una resistencia frente a modos filosóficos imperantes, tales como el racionalismo o el empirismo, que intentan descubrir un orden justificado dentro de la combinación del mundo perceptible, de donde se pueda conquistar el significado universal de las cosas. A partir del decenio, iniciado en 1940, el trío de existencialistas galos: Jean-Paul Sartre, Albert Camus y Simone de Beauvoir, dieron a conocer escritos de corte académico o de ficción que extendieron al público mundial temas existenciales, entre estos destacan: la libertad, la nada, el absurdo, entre otros. (Papineau, 2004: 154-155).

Es de destacar que Jean-Paul Sartre influyó considerablemente en la pensadora y escritora francesa Simone de Beauvoir. La filósofa francesa es exponente de un existencialismo militante y 'feminista', ya que su obra y vida la dedicó por entero a la causa de la reivindicación de los derechos de la mujer siendo una de las precursoras más 
sobresalientes del movimiento feminista. José Ferrater Mora la describe como "la intelectual más influyente de la segunda posguerra mundial" (2004: 330).

Otro pensador francés que destaca por sus postulados de carácter existencial es el Premio Nobel de Literatura Albert Camus. Aunque este novelista y filósofo tomó una distancia deliberada de la concepción existencialista, ya que se manifiesta abiertamente anarquista, movimiento del que fue militante y en el que se reafirma en una de sus obras más brillantes El hombre rebelde, que aparece en 1951; y que analiza diversos temas como el anarquismo, el nihilismo, el marxismo, el terrorismo, el surrealismo, entre otros temas.

Entre otros destacados pensadores que en mayor o menor grado pudieran ser vinculables al existencialismo, se encuentran: Edith Stein, Lev Isaákovich Shestov (conocido en español como León Chestov), Nicola Abbagnano, Nikolai Berdyaev, Peter Wessel Zapffe, Karl Jaspers, Max Scheler, Simone Weil, Abraham Alonzo, Paulo Freire y Emmanuel Mounier.

Como señala José Ferrater Mora, no hay ninguna clasificación del existencialismo realmente satisfactoria, pues o bien se basan en categorías ajenas al mismo movimiento filosófico, como las de cristianismo o ateísmo, tal como lo plantea Pietro Prini, o bien en unas supuestas relaciones más o menos lógicas entre existencia y ser, tal como hace Nicola Abbagnano, o incluso en simples categorías lingüísticas o geográficas, como existencialismo alemán o francés, tal como lo presenta Joseph Lenz.

José Ferrater Mora reconoce que el existencialismo ha provocado numerosas críticas desde otras posiciones filosóficas contemporáneas, entre las que destaca la de algunos filósofos analíticos, como el caso de Alfred Jules, quien ha calificado el existencialismo simplemente como un abuso del verbo "ser" (Ferrater Mora, 2004: 1177). Para los marxistas se trata de una filosofía de la burguesía en su estado de degeneración y descomposición, mientras que, los que José Ferrater Mora denomina "tradicionalistas", los partidarios de la philosohia perennis, consideran el existencialismo como una de las más peligrosas manifestaciones del ateísmo moderno y los racionalistas lo califican como hostil a la ciencia y a toda razón humana, finalmente aquellos que defienden la individualidad entienden que se trata de una actitud saludable frente a cualquier género de totalitarismo.

El pensador Hans Jonas sostendrá que el fundamento del existencialismo será un dualismo encubierto; que determina una separación profunda entre mundo y naturaleza, separación que genera en el hombre un desgarro cosmológico y existencial (1993). Por su 
parte, el barcelonés Alfredo Rubio de Castarlenas, en el año 1980 sugirió el realismo existencial, el cual supone la sorpresa de verse existiendo, pudiendo no haber existido, si cualquier cosa preliminar a ese ser, de las que incidieron en su origen, hubiera sido diferente. Su visión a pesar de que se nutre del existencialismo no se ancla en la angustia, sino en la 'alegre desangustia' de haber podido no ser.

Lograr una aproximación en pro de intentar ubicar en este marco referencial del existencialismo a un filósofo como José Ferrater Mora, será el propósito de dicha investigación.

José Ferrater Mora quien fuera descrito magistralmente por Lola Díaz (1985) “como un bisturí del verbo que corta sin ruido pero con precisión". Pertenece a esa raza de pensadores, educados en la lógica alemana que huyeron de la España franquista más por ética que por política, una cuestión que nunca le ha quitado el sueño a este filósofo menudo y afilado, cuyo trabajo fuera reconocido ampliamente y por nombrar uno de tantos, a los setenta y dos años le fue conferido el premio Príncipe de Asturias.

En las subsiguientes páginas se dará un recorrido que permita adentramiento entre las implicaciones de la propia existencia de este filósofo barcelonés, que ha sido considerado el más destacado del siglo XX. Sus razonamientos filosóficos, la influencia que sobre este tuvieron los grandes filósofos en la materia, al igual que los pensadores de su propio tiempo y su legado intelectual. Todo ello para dar paso a una investigación con mayores honduras que consienta profundizar acerca de sus ideas sobre temas como la ontología, el integracionismo, la tanatología y la existencia misma del ser.

Apasionante será poder indagar acerca del pensamiento de este hombre, quien en las postrimerías de su vida, con una visión brillantemente lúcida, aseguró que le encantaba, tras su jubilación de la docencia, la cual ejerció gran parte de su carrera, dedicar más tiempo para leer y escribir.

José Ferrater Mora le rememoró a Lola Díaz en una entrevista para la publicación Cambio 16 que: "En una novela de Philippe Roth, una chica muy misteriosa le pregunta al protagonista qué es lo que hace durante el día. Y el protagonista le contesta algo que es lo mismo que yo quiero contestarle a usted: durante el día le doy vueltas a las palabras" (1985). 
2. Justificación.

La cosa es encontrar una verdad que sea verdad para mí, encontrar la idea por la que pueda vivir o morir

Sören Kierkegaard

Entre las probables respuestas a la interrogante acerca de quién fuera José Ferrater Mora y el por qué es menester conocerle, surge una afirmación, que bien podría valer inicialmente para contestar dicha incógnita, y es provista por el estudioso Carlos Nieto Blanco, uno de los más dedicados investigadores acerca del trascurrir del filósofo catalán, en su libro y tesis doctoral "La filosofía en la encrucijada: perfiles del pensamiento de José Ferrater Mora", publicado por la Universidad Autónoma de Barcelona, en el año 1985, sostiene: "Ferrater Mora es un filósofo que ha escrito el mejor diccionario de filosofía elaborado por una sola persona" (1985: 57).

Carlos Nieto Blanco en otro ensayo acerca del filósofo, comparte que José Ferrater Mora representa uno de los escasos y grandes hitos del pensamiento español del siglo XX $\mathrm{y}$, como resultado que es de una mente atenta y curiosa, se expande por cuatro grandes dominios de la producción literaria, a saber: El periodismo, el relato, la investigación histórico-filosófica y la creación filosófica en sentido estricto (1984: 1).

Cabe destacar que José Ferrater Mora representará la concreción de una obra cimera dentro de la filosofía contemporánea, que desde su irrupción y aún hasta el presente, cumple un rol de conducción del pensamiento occidental hispanohablante, que claramente se fundamenta a partir de su Diccionario de filosofía, el cual para algunos catedráticos lo ha convertido en uno de los autores de mayor consulta y difusión de los últimos tiempos, pero que ciertamente constituye, desde su aparición y muy probablemente en el horizonte futuro, una de las obras con mayor trascendencia investigativa en materia filosófica, todo ello, sin dejar de considerar el vasto desarrollo literario que obtuvo como filósofo y ensayista que son de gran valor, y que se alza como claro motivo que argumenta la pertinencia de la presente tesis.

En conjunto al Diccionario de filosofía, se ubican no tan aparte un gran grupo de textos vecinos, laterales, frontales, anteriores o posteriores, no solamente complementarios de los aportes del diccionario, sino que además proyectan con amplitud casi insondable las propuestas ontológicas y filosóficas del intelectual español. Escritos vinculados al 
integracionismo, la ontología y el existencialismo, fundamentalmente, en apariencia lamentablemente no tan difundidos, leídos o valorados por los conocedores del gran pensador barcelonés.

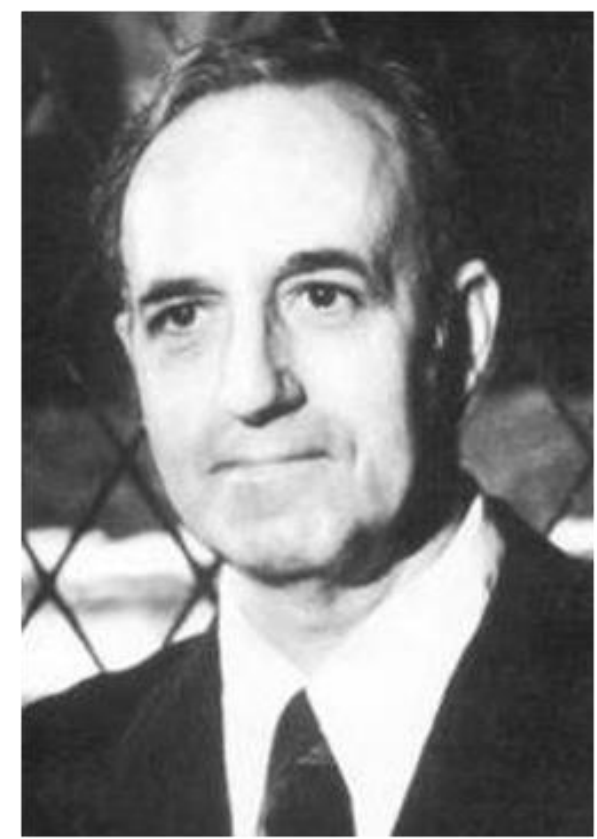

Ilustración 5: José Ferrater Mora

(Fuente: Bibliografía site filosofía.org Tomado de: http://filosofia.org/ave/001/a379.htm)

Posteriormente Carlos Nieto Blanco sostiene sobre la producción intelectual de José Ferrater Mora que:

"En rigor, podríamos decir que la producción de Ferrater alberga tres tipos de discurso: el ensayístico, el filosófico y el narrativo. Si la filosofía -en su doble vertiente creativa e historiográfica-, el ensayo y la narrativa son tres formas de escritura, ser filósofo, ensayista y narrador constituyen tres manifestaciones de la personalidad intelectual del pensador catalán. A su vez, el ensayismo aparece bajo dos subgéneros, a saber, el ensayo de extensión media que se da a conocer por medio de revistas, sean estas de tipo más especializado o generalista, y el artículo periodístico, cuyo destino final, en ambos casos, acabará en formato de libro. Por lo que se refiere al primer tipo, Ferrater fue un ensayista desde la primera hora, mientras que comenzó a ejercer como periodista a partir de 1970” (2015: 1).

Para Carlos Nieto Blanco (2015: 2-5) se tratará de la presencia de un escritor y creador que se pasea cómodamente por la narración, vista como una práctica que pertenece también a la naturaleza de un cierto tipo de discurso filosófico, mejor concebida como historiografía filosófica propiamente dicha, que se une a su vasto cúmulo de artículos 
periodísticos sin dejar por fuera su faceta como cineasta, que confirman el uso de la herramienta narrativa para abordar relatos articulados de conceptos, ideas o 'filosofemas' (teorías filosóficas).

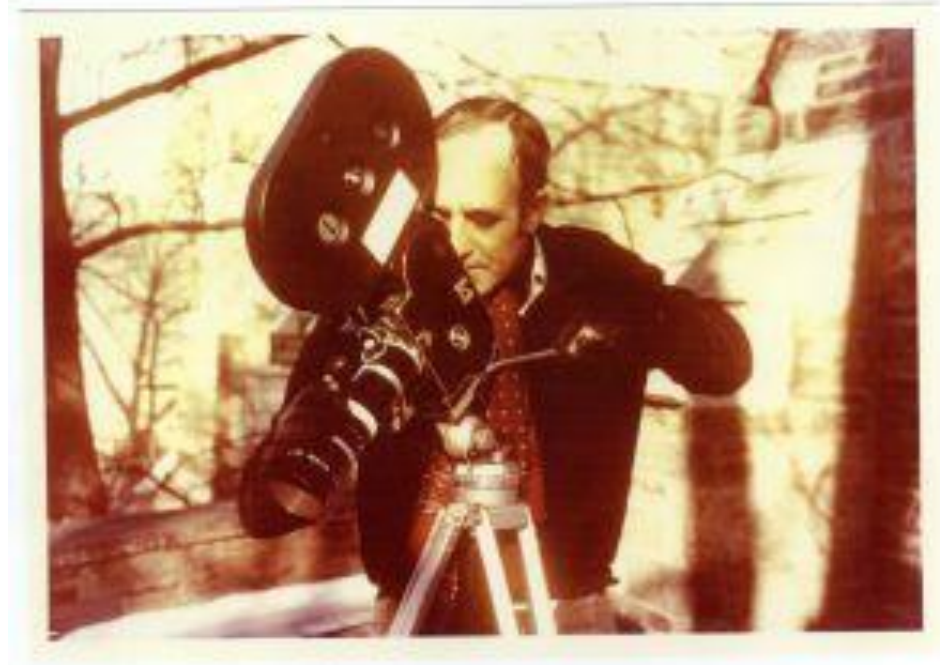

Ilustración 6: José Ferrater Mora y su pasión por el cine.

(Fuente: Sitio electrónico La guía de Filosofía. Sección Grandes Filósofos: José Ferrater Mora. Tomado de: http://filosofia.laguia2000.com/grandes-filosofos/jose-ferrater-mora).

Sin embargo, tal como lo expresa su entrañable amigo Joan Oliver, amistad que por cierto nacerá durante los difíciles momentos del exilio chileno, José Ferrater Mora dejará sentir en su obra un amor al lenguaje muy símil al que le dispensan los poetas. Todo ello agregándole a su estilo rasgos característicos que le añaden belleza y precisión estilística a su producción literaria. Es así como Pere Quart, nombre con el cual acostumbra firmar Oliver, reseña al creador catalán:

"Ferrater Mora es un filósofo que ama el lenguaje casi tanto como un poeta. A decir verdad, su amor por el lenguaje es un amor de pensador. En filosofía, el asunto del que se trata es el pensamiento; el estilo literario debe confinarse a la expresión y modulación de los pensamientos. Actualmente no hay ninguna razón para que el lenguaje no deba combinar la precisión con la belleza. Cuando ello sucede obtenemos la transparencia y la claridad que son características de la prosa filosófica de Ferrater Mora" (Oliver, 1981: 1).

Jordi Gracia describiendo el talante intelectual de José Ferrater Mora, sostiene:

"Me resistiré como mejor sepa a tratar a Ferrater Mora sólo como filósofo, porque me parece que las lecciones más sutiles y perdurables de su obra son literarias. [...] Ferrater Mora fue desde luego un 
filósofo y su obra estrictamente filosófica no estuvo nunca reñida con una vocación literaria muy precisamente entendida. Hacer literatura no era precisamente una forma de rebajar el valor de lo escrito, ni era tampoco una concesión fácil a públicos ignaros, sino un ejercicio intelectual que lo arrebató desde los veinte años hasta la hiperactiva vejez del escritor. [...] Y Ferrater Mora no quiso cerrar ninguna puerta ni al experimento literario ni tampoco desde luego a la conjetura: fue un explorador literario nato, y fue buscador también, atento, curioso, constante e inconstante" (Gracia, en Ferrater Mora, 2005: 13-14).

Es así como Jordi Gracia testifica que en José Ferrater Mora el ejercicio filosófico debe ser elevado a otra dimensión, que no empero será la parte central y visible de su obra, no obstante se engranará con un estilo propio y cuya vena creativa desbordará todos los límites.

El ejercicio por desenfocar quizás lo filosófico y colocar en primer plano lo literario de su obra, conlleva a la reflexión que hiciera el mismo José Ferrater Mora acerca de su vocación de escritor, plasmado en un retazo de autobiografía intelectual titulado “Confesión preliminar", el cual es una autoexposición con la que encabeza los dos gruesos volúmenes de sus Obras selectas (1967).

"De vez en vez, si bien en fechas ya algo remotas, ha cruzado por mi magín la quimera de ensayar la novela o, si más no, el relato. No recuerdo siquiera si alguna vez puse manos a la obra, pero si tal ocurrió no debí de pasar de la segunda página. No me hubiera afligido nada ser capaz de novelar, pero he tenido que contentarme con ser lector de novelas. Evidentemente, no he nacido para narrar" (Ferrater Mora, 1967: 17).

Es esta confesión José Ferrater Mora sostiene 'que no ha nacido para narrar', lo cual en opinión de Carlos Nieto Blanco responde más a un lamento, pues se infiere que al autor catalán le habría gustado ser un narrador. Deseo que eclosionará a finales de la década de los años setenta para crecer imparablemente a lo largo del siguiente decenio.

"Se diría que Ferrater Mora estaba preparando el terreno, barruntando una posibilidad que le aguijoneaba hasta dejarlo insatisfecho. Sólo quien desconozca el pensamiento de Ferrater Mora podría tomarse totalmente en serio su "no he nacido para narrar", $y$ no abonarse al beneficio de la ironía, negando de plano una posibilidad en la que, sin embargo, confiaba. Por eso, en las últimas fechas de su producción, las de los años ochenta, estaba emergiendo ya una nueva modalidad de su vena creativa. Para quien no había nacido para narrar no estuvo mal haber publicado en los últimos diez años de su vida cinco novelas y dos libros de relatos." (Nieto Blanco, 2015: 16). 
Para Carlos Nieto Blanco (2015) la trayectoria intelectual de José Ferrater Mora puede constituir: "un caso, si no único, sí excepcional, no sólo dentro de la cultura española, sino en el panorama internacional, escasamente valorado tanto dentro como fuera de España" (17).

José Ferrater Mora despierta el interés investigativo dado que se percibe estar ante la presencia de un creador en cuya producción se resume una intertextualidad que es alimentada por la reescritura constante de su obra, en una búsqueda incesante por mejorar su evolución intelectual, hecho que responde a su insatisfacción permanente que en palabras de Carlos Nieto Blanco (2015) no es más que un claro testimonio de su aspiración hacia la perfección.

3. Fines y objetos de la investigación.

\subsection{Hipótesis.}

Como ya se ha hecho clara mención mediante páginas precedentes, abordar los planteamientos que permitan conformar el escenario que determine la certera o no delimitación de una filosofía existencial en el pensamiento del filósofo español José Ferrater Mora será el principal norte a seguir como parte del presente proyecto investigativo.

En dicho camino se abrirán distintas perspectivas que admitirán las siguientes conjeturas hipotéticas y que de aquí en adelante se intentarán dilucidar, en conjunto o de modo aislado:

H1. José Ferrater Mora desarrolló una filosofía de carácter existencial.

H2 Existen elementos existenciales en los razonamientos filosóficos desarrollados por José Ferrater Mora.

H3. En la filosofía de José Ferrater Mora son observables elementos existenciales en consonancia con el método integracionista.

H4. Es detectable la filosofía existencial en la ontología y metodología integracionista de José Ferrater Mora.

H5. José Ferrater Mora fue un filósofo existencial con su propio sistema filosófico. 
Tomando en consideración de que el académico José Ferrater Mora, fundamenta su propio sistema filosófico al que él mismo denomina como "integracionismo", se formula la hipótesis de la presencia de elementos existenciales en la filosofía de José Ferrater Mora.

Haciendo uso del método de investigación documental y bibliográfica, las recién presentadas hipótesis servirán para exponer la cosmovisión sobre el existencialismo y la filosofía existencial, así como para abordar la ontología, el integracionismo y la tanatología del escritor catalán, todo ello a través de lecturas críticas que permitan alcanzar un juicio equilibrado, reflexivo, acorde con su tiempo y espacio, sobre el que se irán hilvanando elementos que permitan realmente analizar y continuar analizando su obra escrita.

La investigación versará en ubicar los diferentes rasgos distintivos del existencialismo presentes en la amplia obra del pensador barcelonés, en temas fundamentales como la ontología o el integracionismo, entre tantos otros a modo comparativo con los conceptos emitidos en sus libros, incluyendo el muy difundido Diccionario de filosofía, así como una cuidada revisión de estos temas en las páginas de sus obras más representativas.

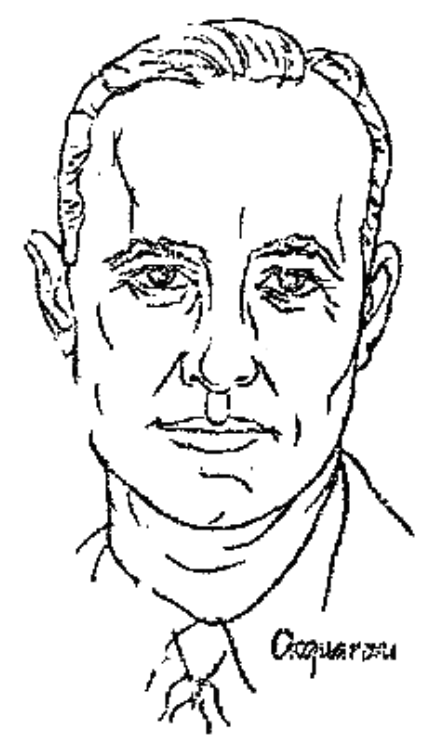

fose Fematar Nora

Ilustración 7: Dibujo de José Ferrater Mora

(Fuente: Citado por Gonzalo Fernández de la Mora. El Ser y la Muerte, de José Ferrater Mora. ABC diario ilustrado 1963. Tomado de: http://filosofia.org/hem/dep/abc/9630725.htm)

La lectura pertinente de sus conceptos, planteamientos, análisis, afirmaciones, consideraciones y declaraciones biográficas, sumada a los elementos bibliográficos, 
permite establecer un carácter distintivo, que finalmente funciona para ubicarlo en una corriente filosófica muy amplia, pero con sus respectivas particularidades.

Conocer su vida y obra permite una visión holística y sistémica en el pensamiento de José Ferrater Mora, recordando que no sólo lo que se dice y se escribe en la filosofía reafirma el carácter de quien es considerado filósofo, todo lo que hace y expone junto a su historia determinan esa identidad.

El integracionismo de José Ferrater Mora, al ser definido por él mismo, es presentado precisamente como un método filosófico. Para los fines de esta investigación se determina la diferencia entre su definición como filósofo, la visión de su propio pensamiento y como una lectura de su obra lo ubica dentro o no de la corriente existencial.

\section{Método de investigación.}

\subsection{Estado de la cuestión.}

Se ha optado por orientar los procedimientos de indagación bajo el método de la investigación bibliográfica, también descrita por algunos autores como investigación documental, en primera instancia por servir de introducción para el trabajo posterior con otros métodos de investigación, en manos de futuros investigadores, así como por su proximidad y pertinencia con el tema general del saber humanístico, o específico del conocimiento filosófico, ambos territorios ligados desde su génesis al universo bibliográfico. Hecho que permite una mayor fluidez en la obtención de los materiales primarios en atención a las más recientes formas, es decir, incluyendo los formatos novedosos como los documentos electrónicos, siempre que estén a tono con las necesidades expresivas del tema trabajado.

Se adopta por tratarse de una variación de la investigación científica, cuyo objeto es analizar los diferentes fenómenos que se presentan en la realidad utilizando como recurso principal los diferentes tipos de documentos que produce la sociedad y a los cuales tiene acceso el investigador (Plazas, 2011).

Se justifica fundamentalmente su uso por tratarse del modelo que se ubica más cónsono y de acuerdo con la fuente estudiada, de la cual se adquieren en este caso los datos y argumentos, es decir, al atender las diferencias metodológicas de los muchos otros tipos 
de investigación, se considera aquí a la investigación bibliográfica como la más apropiada al tipo de objeto abordado; que en este caso se trata de un hecho cultural y académico.

Vale hacer mención, que la investigación documental trabaja principalmente con dos tipos de fuentes: directas e indirectas. Estas fuentes proporcionan información relativa al origen y cercanía con el hecho social trabajado. En la generalidad la definición de la investigación documental se restringe a la búsqueda de documentos, es decir, búsqueda bibliográfica, pero se debe aclarar que a la hora de llevar a cabo una investigación, los documentos no son las únicas fuentes para construir conocimiento, debido en principio, por la diversidad que existe entre fuentes directas e indirectas. En ese sentido se considerarán además otros tipos de fuentes que proporcionen la mayor cantidad de información en la construcción de conocimiento, como son las fuentes orales y las fuentes no convencionales (Plazas, 2011b).

Ya que, tal como bien lo señala Galán Amador (2011), el objetivo de la investigación documental, es elaborar un marco teórico conceptual para formar un cuerpo de ideas sobre el objeto de estudio y así descubrir respuestas a determinadas interrogantes a través de la aplicación de procedimientos documentales. Estos procedimientos han sido desarrollados con el objeto de aumentar el grado de certeza de que la información reunida será de interés para los estudiosos de la materia y que además, reúne las condiciones de fiabilidad y objetividad documental. En definitiva, se trata de una técnica documental que permite la recopilación de información para enunciar las teorías que sustentan el estudio de los fenómenos y procesos, al tiempo que incluye el uso de instrumentos definidos según la fuente documental a que hacen referencia.

Dicho tipo de investigación, es atendido desde el paradigma cualitativo, dado que es el que guarda la más estrecha relación con el resto del proyecto investigativo, pues se trabajan obras fundamentalmente bibliográficas, que corresponde al área natural del desarrollo del pensamiento a lo largo del tiempo, todo ello como fuente primordial para el tratamiento de todo el trabajo. El objetivo es firme, apuntando a un solo fin, como es ampliar el conocimiento científico, en principio, y filosófico-humanístico como intención última. Contribuyendo a través de la investigación a la difusión del tema desarrollado por los mismos soportes bibliográficos, es decir, en marco de acción del conocimiento generador de sapiencia, buscando y generando saber. 
La obra de José Ferrater Mora, es en parte tan colosal como extraña y paradójicamente, aún en la actualidad ante su valor y potencialidades, escasamente difundida, es por ello que tomando en consideración los enunciados anteriores, se han incluido en el presentado trabajo, algunos recursos electrónicos, propios de la actualidad y elevadamente valiosos, sumamente apropiados para una mejor comprensión de las ideas presentadas, tanto como para la mejor disposición del vasto territorio abarcado por la obra intelectual ferrateriana.

Sobre este método, cabe resaltar lo expuesto por el académico Umberto Eco, en su ya clásico texto metodológico Cómo se hace una tesis (2001: 70), donde señala que: "presupone una bibliografía ya elaborada", lo que adicionalmente: "significa buscar aquello cuya existencia no se conoce todavía". El catedrático italiano Umberto Eco sentencia además: "La consulta de los repertorios bibliográficos-siempre que estén puestos al día- es esencial para completar la búsqueda" (2001: 71). Lo que justifica acceder a las fuentes mediante minuciosos procesos de consulta en bibliotecas físicas y digitales.

La investigación bibliográfica ofrece una integración del conocimiento generado, con el conocimiento existente para el momento de realización de la investigación, de las obras integrantes, tanto bibliografía directa como indirecta de literatura especializada, que le permiten al investigador informarse al respecto de qué se conoce o se ha publicado y qué no, pudiendo precisar incluso los motivos de tal situación. Sobre sus especificaciones conceptuales se hallará que:

"Una investigación bibliográfica o documental es aquella que
utiliza textos (u otro tipo de material intelectual impreso o
grabado) como fuentes primarias para obtener sus datos. No se trata
solamente de una recopilación de datos contenidos en libros, sino que
se centra, más bien, en la reflexión innovadora y crítica sobre
determinados textos y los conceptos planteados en ellos." (Campos
Ocampo, 2009: 17).

Sobre este mismo orden se desprenden las siguientes acotaciones, que especifican, la correspondencia o no, con la línea investigativa desarrollada y la naturaleza de los elementos informativos distribuidos en las diferentes partes constituyentes del trabajo:

"A pesar de su nombre, no es obligatorio que se centre en libros; también puede recurrir a otro tipo de fuentes documentales como películas, música, pinturas, microfilmes, sitios en la Internet. La 
definición depende más bien del carácter fijo de las fuentes o sea, que no cambian con el tiempo" (Campos Ocampo, 2009: 17).

Tomando en consideración los enunciados aspectos, se ha incluido en el presente trabajo el uso de algunos recursos electrónicos, propios de la actualidad, sumamente apropiados para una mejor comprensión de las ideas presentadas, tanto como para la mejor disposición del vasto territorio abarcado por la obra intelectual ferrateriana.

Se reafirma la importancia del método de la investigación bibliográfica y documental por los rasgos que caracterizan a la obra escrita y publicada de José Ferrater Mora, ya que la misma se encuentra disponible en sus diversas ediciones en bibliotecas, librerías, fuentes electrónicas, incluyendo sitios web exclusivos; que facilitan en cierta medida su comprobación y verificación.

Adicionalmente la investigación bibliográfica ofrece una integración del conocimiento generado, con el conocimiento existente para el momento de realización de la investigación, de las obras integrantes, tanto bibliografía directa como indirecta de literatura especializada, que le permiten al investigador informarse al respecto de qué se conoce o se ha publicado y qué no, pudiendo precisar incluso los motivos de tal situación. 


\section{CAPÍTULO 1: PERFIL INTELECTUAL DE JOSÉ FERRATER MORA.}

5. Semblanza de José Ferrater Mora.

5.1. Visión historiográfica.

El siglo XX dejó un legado significativo para la filosofía y el pensamiento en España. Nombres como: José Ortega y Gasset, Miguel de Unamuno, José David García Bacca, María Zambrano, entre otros, destacan por su reconocida obra. Y entre ellos engalana al pueblo catalán el filósofo José Ferrater Mora, quien fuera calificado por Gonzalo Fernández de la Mora como "un nómada de una a otra orilla del Atlántico" (1963: 41), por ser uno de los tantos literatos que el franquismo llevó al exilio en América.

Mayúsculo es el reto por describir el devenir existencial de José Ferrater Mora quien en su propia autobiografía sostiene:

"Algunos filósofos afirman que la 'biografía completa' de una persona debe incluir no sólo hechos reales, sino también posibilidades no realizadas. Lo que podría haber sucedido a la persona, argumentan, es tan esclarecedor como lo que realmente sucedió. Me parece interesante esta afirmación, pero algo absurda. Hay más que suficiente para saber acerca de la vida real de una persona sin ser gravado por sus vidas posibles, o alternativas" (Sitio electrónico oficial de José Ferrater Mora).

En ese camino, se posiciona entonces a un pensador catalán llamado José Ferrater Mora, nacido en Barcelona, España, el 30 de octubre del año 1912, quien se matricula en el Seminario-Colegio de Santa María del Collell ubicada en la bella ciudad catalana de Banyoles también conocida como Bañolas en la provincia de Gerona, estudios que realiza entre los años 1922 hasta 1925, a la par que realiza diversas labores entre ellas trabajar en distintos cometidos como bancario o comercial de automóviles mientras preparaba el bachillerato, aunque principalmente se ocupó de traducciones para editoriales y agencias de publicidad, ya que desde muy joven se aficionó a los idiomas y mientras se licencia de bachiller emprende la escritura que lo llevará a lo largo de su vida a tener una obra tan prolífica como diversa, ya que José Ferrater Mora como ya se ha hecho mención no sólo escribió sobre filosofía, sino que además incursionó en la narrativa, guiones de cine y periodismo.

Habiendo culminado el bachillerato en el año 1932, se matricula en la Universidad de Barcelona en la Facultad de Filosofía y Letras, obteniendo su licenciatura cuatro años después. Con apenas veintidós años, logra publicar su primer libro Cóctel de verdad 
(1935), una recopilación de ensayos que incluyen estudios sobre las traducciones culturales de Europa, España y sobre todo Cataluña, que habían sido publicados en diversas revistas, que además es reseñado en varios medios y ya para ese momento era calificado como un prometedor y joven filósofo.

Precisamente Coctel de verdad dará a conocer su visión acerca las circunstancias que rodean al ser justo en los momentos que ameritan una llamada definición de sí mismos, allí plasmará entonces el enfrentamiento personal que su propia existencia experimento en tiempos de pre y post guerra, es así como reseña:

"Cuando la Dictadura estaba a punto de morir en España, voces corrían los más extraños imperativos. "Hay que definirse, hay que definirse", gritaban. ¡Definirse!, palabra de pura emoción socrática. ¡Cuánto quería yo entonces a esas voces! ¡Cuánto esperaba yo entonces de esas voces! Mas, cuando llegó la hora de cumplir la hermosa promesa, la definición empezó a darse en los siguientes términos: "Soy republicano." "Soy monárquico." "Soy radicalsocialista."

Ahora, aún encontramos jóvenes voces en cuyos labios la palabra "definición" adquiere todavía temblores místicos. "No estoy definido", dicen. "No sé si inclinarme por el fascismo o por el marxismo." (Resurrección de la Metafísica en nuestra época. Fascismo, Marxismo: Absolutos en que, como en el de Schelling, todos los gatos son pardos.)

A mí, particularmente, me parece excelente el definirse. Pero lo que hace esa gente no es ninguna definición, como la que yo, en mi pobre ignorancia de las cosas públicas, me imagino. Para mí, definirse es delimitar bien el contorno que nos separa de los demás hombres y de las demás cosas. Para mí, la definición es un modo de conocimiento. Por eso, en mi incapacidad de definirme de otra forma escueta, lanzo aquí muy cerca las palabras que constituyen mi propia definición intransferible" (Ferrater Mora, 1935: 57-59).

Acercándose a la mundanidad del ser, se plantea una "auto-definición" llana y sin retóricas, que a pesar de estar plasmada en una obra, la cual para muchos especialistas no responde a la esencia madura del José Ferrater Mora, que será luego una constante en sus textos posteriores al Diccionario filosófico, de alguna forma deja entrever una sagacidad irónica en su pluma, que ciertamente sí le acompañará a lo largo de su obra literaria, señalando así:

"Ante todo, definición de las cosas, delimitación de las cosas, pura y elegante separación del contorno. Altura, anchura, espesor, duración.

Tengo las cuatro dimensiones que toda física que se haga estimar postula: tres para el espacio y una para el tiempo. Las del espacio 
dicen que soy de estatura media, tendiendo hacia lo alto; de angosta anchura, tendiendo hacia lo delgado; de espesor en armónico conjunto con la anchura. Cabeza mediana, tendiendo a la pequeñez; frente ancha, tendiendo a la ciencia. Ojos negros, oscuros. (Es uno de mis pequeños orgullos. Spinoza tenía los ojos negros, oscuros. Véase la descripción de Colerus.) Nariz de extraña contextura: armónica de frente, indiferente desde el lado izquierdo; aguileña, judía, desde el lado derecho. (Es otro de mis pequeños orgullos. Una nariz así es anuncio de grandes cosas.) Labios proporcionados, sencillos, con una ligera mиeca en la sonrisa (pequeño Jano bifronte de mi cara los labios: un lado mira a San José y otro a Maquiavelo). Cara flaca, severa; infinitesimal aparato auditivo. Manos finas, pequeñas, en perpetua ansia de pereza. Cuerpo largo, delgado, en perpetua ansia de letargo." (Ferrater Mora, 1935: 57-59)

La Guerra Civil española y su exilio marcaran su diario vivir como se podrá apreciar páginas más adelante al hacer referencia directa a esos períodos de su vida.

En el contexto de su vida personal, después de tres décadas de matrimonio decide separarse en el año 1970 de Renée Rosalie Petitsigné, su primera esposa, a quien había conocido cuando estuvo de traductor y guía de los extranjeros que visitaban el frente republicano del Este. Tuvieron un hijo, Jaime Claudio Ferrater.

En los predios de ese tiempo, José Ferrater Mora se relacionó con la norteamericana Priscilla N. Cohn, con la que contrajo nupcias en el año 1981, a pesar de haber convivido desde la separación de su anterior matrimonio.

No es posible cerrar esta visión historiográfica sin hacer hincapié en su propia personalidad, la cual tuvo ciertas particularidades, es propicio hacer referencia de lo expuesto por su página institucional, donde le describen de la siguiente forma:

"Tal vez es cierto que la persona pública oculta de algún modo a la persona privada, tal vez es difícil conocer a alguien cuyo ingenio y la ironía es tan marcado que no siempre se puede ver fácilmente si debajo hay una persona tímida, amable y vulnerable o tal vez simplemente Se niegan a abandonar nuestro estereotipo del intelectual fresco, tranquilo y recogido. Tal vez la misma agudeza del pensamiento de Ferrater Mora llevó a algunos a creer que era desapasionado, ya que tendemos a contrastar la pasión con el intelecto como si fueran incompatibles: pensamos en una persona apasionada como emocional y tal vez incluso algo irracional, mientras que vemos un intelectual como Racional, no emocional y desapegado. Sin embargo, un intelectual no necesariamente carece de pasión. Un intelectual bien podría tener un apasionado respeto por las ideas, así como otras cosas.

Ciertamente Ferrater Mora era intelectual, pero si se ajustaba al estereotipo de un intelectual es otra cuestión. El problema con los estereotipos es que a menudo son exagerados o simplemente falsos, y 
el problema de ver a Ferrater Mora a través de la lente de este estereotipo es que a menudo no parecía encajar: era demasiado irreverente, demasiado irónico, demasiado lleno de vida para ser un "intelectual adecuado". Él mismo explicó que hay una enorme diferencia entre ser intelectual y ser pedante y que a menudo los dos estaban confundidos. No admiraba a los pedantes. Tal vez Miro Quesada argumentara que era un súper racionalista en su pensamiento, pero no era frío ni indiferente. Un colega de Bryn Mawr, que había conocido a Ferrater Mora durante años, comentó sobre su muerte que nunca había aprendido a decir cuándo hablaba en serio y cuando no lo era, pero Ferrater Mora le ofreció un guía: Si sueno serio, entonces estoy bromeando; Si sueno como si estuviera bromeando, puede que no lo sea." (Sitio electrónico oficial Ferrater Mora).

José Ferrater Mora fallece el miércoles 30 de enero de 1991, a la edad de setenta y ocho años, despidiéndose desde su Barcelona natal.

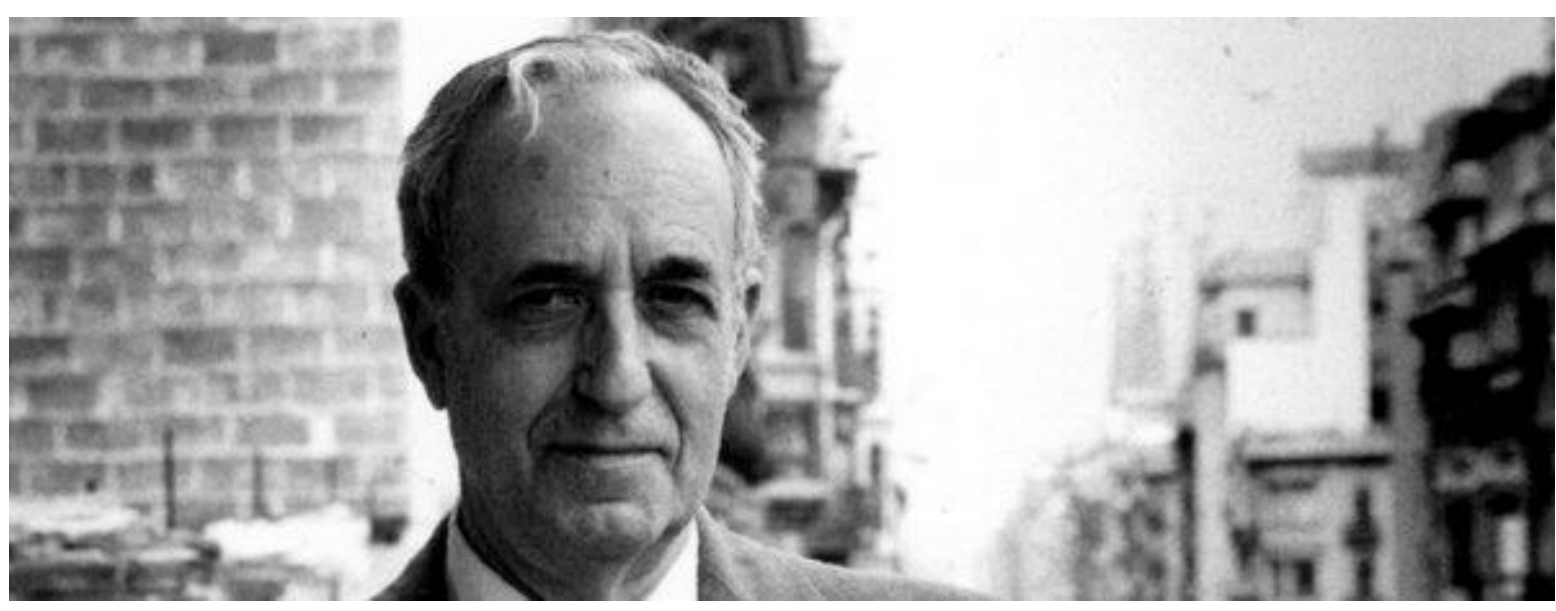

Ilustración 8: José Ferrater Mora

(Fuente: Sitio electrónico fteducando.blogspot.com - Reseña Diccionario Filosófico. Tomado de: http://fteducando.blogspot.com/2015/08/diccionario-filosofico-de-jose-ferrater.html)

Su fallecimiento en el año 1991 representó un hecho muy peculiar, José Ferrater Mora, quien a pesar de tener residencia fija en Estados Unidos de América, el azar, o quizás el destino, llevó a que el filósofo falleciera precisamente en Barcelona, su ciudad natal, lugar al que había viajado para presentar la que fuera definitivamente su última novela.

Su memoria y legado es apreciado en el mundo académico, enciclopédico y filosófico. El sitio electrónico www.ferratermora.org conserva parte de su legado con un inmenso archivo que incluye su obra epistolar. Josep-María Terricabras fundó una cátedra con su nombre que se ocupa de estudiar, divulgar y difundir la obra de José Ferrater Mora. Académicos, profesores, estudiantes, investigadores y amantes de la filosofía, no sólo en 
castellano, sienten una gran admiración por un filósofo que sigue vigente en el pensamiento y que trasciende los horizontes del saber.

\subsection{Formación e influencia filosófica.}

Una de las grandes influencias que tendrá José Ferrater Mora en sus tiempos de juventud estará en la figura de Joaquín Xirau Palau, de educación alemana, tal como lo revelan apuntes de su biografía plasmada en su sitio electrónico oficial. Sin embargo vale destacar que se verá muy influenciado por pensadores como Miguel de Unamuno, José Ortega y Gasset y Eugenio d’Ors, en lo que sería a consideración de Carlos Nieto Blanco (1985: 16) "casi una reconciliación de la filosofía con la cultura", dado que ellos en parte han sentado las bases del desarrollo filosófico español.

Junto a ellos así como también a otros numerosos representantes tanto de la filosofía continental, como de la llamada universal, José Ferrater Mora fomentará el desarrollo creativo de su pluma literaria. Es así como produce cuentos, novelas y poemas. Además textos sobre lógica matemática y también incursiona en el periodismo, así como también guionista de cine.

De hecho, el mismo José Ferrater Mora al ser entrevistado por la revista Teorema en 1972, justamente de primera mano reseña los filósofos que marcaron hito en su ideario formativo. A continuación se rescata parte de lo que compartiera a la publicación en su momento:

“T.: ¿Quiénes son los filósofos y cuáles las obras filosóficas que más directa o más entrañablemente han influido en tu pensamiento?

F.: Son demasiadas para que sea justo con las que, por descuido o falta de espacio, dejaría de mencionar. Entre los clásicos he leído, y comentado muy a menudo en mis clases la Crítica de la razón pura, de Kant, pero no sé si esta obra ha influido más «directa y entrañablemente que otras» en mi pensamiento (sospecho que mucho, Pero no podría decir cuánto). Hay autores que admiro grandemente, pero cuyas influencias sobre mi estimo escasas; otros que seguramente han influido mucho y que seguramente admiro menos. La verdad es que, como decía en la respuesta a la, primera pregunta, dejo esta cuestión para los que puedan, o, quieran, verla «desde fuera», a través de un examen imparcial de textos y con una objetividad que yo seguramente no podría alcanzar." (Teorema, 1972: 97-108) 
Haciendo referencia a la influencia de Immanuel Kant en su pensamiento filosófico, José Ferrater Mora reconoce que además de la lectura sus libros, los usaba con regularidad en sus clases. Aunque no hay un registro audiovisual conocido o disponible de las clases de José Ferrater Mora, es posible que el intelectual catalán mostrara ante su audiencia una parte significativa de las influencias filosóficas a las que tributó, que no necesariamente o explícitamente pueden verse reflejada en su densa obra escrita. Incluso las lecturas de orden literario, las películas que a lo largo de su vida contempló y la influencia de la lectura de la prensa diaria sería complejo establecer qué otras influencias pudieron ser importantes en su pensamiento y que hayan caracterizado lo que el propio José Ferrater Mora llama "integracionismo" o "empirismo dialéctico", que corresponde a su propio sistema o método filosófico.

Siguiendo las indicaciones del propio José Ferrater Mora quien invita a 'ver desde fuera' su obra, podría decirse que en ésta se evidencia, con mayor o menor acento, la influencia que dejarán sentir filósofos como Jean-Paul Sartre y Xavier Zubiri, este último por cierto con especial fuerza. A pesar de ello es de notar que José Ferrater Mora mantendrá una posición ecléctica que lo alejará de seguir una dirección firmemente determinada por sus influenciadores, con lo cual se rescata que algunos estudiosos lo consideren en sí mismo un creador de pensamiento.

Es importante considerar que sus influencias también se verán plasmadas en su obra, como en el caso de El ser y la muerte (1962) en donde hace más de una decena de citas de Jean-Paul Sartre, o donde cita a Hegel, incluso, hace mención especial de la dialéctica, razón por la que considera que la dialéctica, en este caso considerar especialmente a Hegel, forma parte de su sistema y método filosófico, el que usa para su praxis filosófica, incluso su visión sobre la dialéctica la aplica considerablemente al realizar una obra que compara y analiza diversos sistemas y formas de pensamiento como el Diccionario de filosofía, que se sabe no es un simple diccionario, sino una obra enciclopédica de envergadura que contiene además reseñas de filósofos, historia de la filosofía y extensos análisis de conceptos claves en la filosofía clásica y moderna.

Y es que será meritorio además traer a colación las consideraciones del mismo Carlos Nieto Blanco quien para justificar el título de su obra "La filosofía en la encrucijada" (1985) destaca que existen al menos cuatro razones que abonen la idea de que el desarrollo literario de José Ferrater Mora habita precisamente en una encrucijada, 
pero ésta vista como "un observatorio tan perfecto como arriesgado, pues el ímpetu de los viajeros puede acabar por desplazar o eclipsar a quien ha elegido semejante posición y de ese riesgo es consciente quien se ha situado en dicha perspectiva" (1985: 17). Dado que ello implicará la adopción siempre, ya sea según tema, época o contexto, de una determinada dirección de contenido sin que ello haga olvidar al resto.

Es así como se concibe en primer término que es producto de mundos distintos, a raíz justamente de los escenarios en los que les ha tocado convivir y desarrollar su obra. Todo ello aunado a su natural curiosidad y apertura a un universalismo cultural que se asienta en su muy amplio interés a la lectura.

En segundo lugar, por la encrucijada propia de modos de vivir y pensar que provocan las humanidades y la ciencia, que en José Ferrater Mora se dilucida en su preocupación por el hombre y por la naturaleza, observable en sus primeras obras que luego decanta en lo que Carlos Nieto Blanco (1985: 109) definirá como su 'integracionismo metodológico'.

Será precisamente el discurso ontológico de José Ferrater Mora lo que a consideración de Carlos Nieto Blanco (1985: 18) lo sitúe en una encrucijada de la tradición fenomenológica, de la tradición analítica y de la tradición naturalista. Para finalmente entender esa encrucijada que experimenta el autor al tener un desarrollo literario que no se encasilla y que por el contrario se libera a través del abordaje de la lógica, la ética, la historia de la filosofía, la ontología.

Es precisamente esos elementos los que dan una caracterización particular, José Ferrater Mora busca "tender puentes" entre diversos sistemas filosóficos, incluso aquellos que se consideran antagónicos, irreconciliables y desde allí filosofar con un sentido empírico y a la vez dialéctico, debido a que el filósofo catalán no descarta, no desacredita ni desdeña ideas, él observa los conceptos, realiza un análisis de la situación, esencia y los acerca desde su visión ontológica.

El integracionismo no es pasivo, es una forma dinámica de hacer filosofía, un abordaje a la ontología, la historia de la filosofía y los aspectos fenomenológicos que exponen una integración del pensamiento sin constituirse en una forma ecléctica de filosofía, sino en una metodología con particularidades y que no busca superar o establecer dogmas ni mucho menos tomar partido en una corriente en particular. 
Como ya se ha evidenciado uno de los pensadores más influyentes en José Ferrater Mora será el mismo Miguel de Unamuno. El filósofo hace un estudio de la obra filosófica del pensador español, desarrollando un amplio panorama que evoca desde sus circunstancias biográficas, históricas y académicas y las deja plasmadas en su libro Unamuno, bosquejo de una filosofía (1944). Además, José Ferrater Mora elabora un significativo artículo sobre Miguel de Unamuno en su Diccionario de filosofía, obra que además aporta una amplia bibliografía, no solamente de la obras del respetado filósofo y académico, sino también sobre libros que se han escrito en torno a su obra.

Carlos Nieto Blanco realiza una breve semblanza que será plasmada en la revista Anthropos 49, en la cual expone:

"La contextualización de la obra de Ferrater Mora en tanto que filósofo español se hace desde una doble perspectiva: desde el punto de vista de su actividad cultural y generacional se encuentra incluido dentro de la Generación del 36. Y desde el punto de vista de las influencias recibidas, que constituirán puntos de partida de su pensamiento, su filosofía tiene en cuenta la de Unamuno, Ortega y Gasset, y d'Ors, aunque lo haga desde la tradición filosófica catalana." (Nieto Blanco, 1978: 3).

A manera de revisión, se rescata a continuación el artículo contenido en el Diccionario de filosofía, en esta oportunidad se usa como recurso la edición primera de la obra publicada en México (1941), su utilización se sustenta en el hecho de que el mismo sintetiza un análisis exhaustivo de la obra de Miguel Unamuno y aporta una visión que deja entrever la influencia que éste ejerce en su obra creativa:

“MIGUEL DE UNAMUNO (1864-1936)

Nacido en Bilbao, fue profesor y rector de la Universidad de Salamanca. Su vida y su pensamiento, intimamente enlazados con las circunstancias españolas y con la gran lucha sostenida desde fines del siglo pasado entre los europeizantes y los hispanizantes, lucha resuelta por Unamuno con su tesis de la hispanización de Europa, pueden comprenderse en función de las intuiciones centrales de su filosofia, consistente en una meditación sobre tres temas fundamentales: la doctrina del hombre de carne y hueso, la doctrina de la inmortalidad y la doctrina del Verbo. La primera, que es acaso su problema capital y el fundamento de todo su pensamiento, es expuesta por Unamuno al hilo de una polémica contra el hombre abstracto, contra el hombre tal como ha sido concebido por los filósofos en la medida en que hacían filosofía en vez de vivirla". (Ferrater Mora, 1941: 403-404).

Se observa que los temas fundamentales en el pensamiento de Miguel de Unamuno son en torno al hombre, abordando su realidad, no desde lo abstracto, sino de lo vivencial. 
Hacer filosofía sobre la vida sin vivirla, sin experimentar, abstraerse en filosofar sin el accionar de lo que acontece es motivo de crítica profunda:

"El hombre, que es objeto y sujeto de la filosofía, no puede ser, según Unamuno, ningún «ser pensante»; por el contrario, siguiendo una tradición que se remonta a San Pablo y que cuenta entre sus mantenedores a Tertuliano, San Agustín, Pascal, Rousseau y Kierkegaard, Unamuno concibe el hombre como un ser de carne y hueso, como una realidad verdaderamente existente, como «un principio de unidad y un principio de continuidad». La proximidad de Unamuno con el existencialismo, subrayada ya en diversas ocasiones, no impide que su intuición y sentimiento del hombre sean, en el fondo, de una radicalidad mucho mayor que la expresada en cualquier filosofía existencial." (Ferrater Mora, 1941: 403-404).

En esta lectura, hay una clave en la afirmación de José Ferrater Mora respecto a la proximidad de la filosofía unamuniana con el existencialismo, y lo sitúa dentro de la tradición que lo acerca a Kierkegaard, que como se expresa en el presente trabajo de grado, es el pensador al que se considera iniciador del existencialismo. Sin embargo, no procede a etiquetarlo o enmarcarlo como un existencialista puro, hecho que lo coloca lejos de los absolutismos y dogmatismos que por lo general muchos pensadores suelen abusar de catalogar o clasificar a corrientes de pensamiento que en ocasiones son contrapuestas, al calificarlo como un pensador con un sistema radical con expresión propia no tributaria a cualquier corriente filosófica existencial.

Eso ocurre en el propio José Ferrater Mora al bosquejar su propio sistema integracionista. Esa relación respecto a Miguel de Unamuno la transfiere al situar al integracionismo fuera del existencialismo, pero como ocurre con su propia afirmación, no deja de estar aproximado por las influencias que el existencialismo ejerce en los temas sobre el ser, la muerte, la vida y demás tópicos que caracterizan las propuestas de las diversas corrientes existencialistas, aunque estén diametralmente opuestas, se encuentran en ese camino.

Cabe la pregunta: ¿A qué se opone Miguel de Unamuno dentro del universo filosofal? José Ferrater Mora da su visión:

"En su lucha contra la filosofía profesional y contra el imperio de la lógica, en su decidida tendencia a lo concreto humano representado por el individuo y no por una vaga e inexistente «humanidad», Unamuno hace de la doctrina del hombre de carne y hueso el fundamento de una oposición al cientifismo racionalista, insuficiente para llenar la vida humana concreta y, por tanto, impotente para confirmar o refutar lo que constituye el verdadero ser de este 
individuo real y actual proclamado en su filosofía: el hambre de supervivencia y el afán de inmortalidad. Toda demostración conducente a demostrar o a refutar estos sentimientos radicales es para Unamuno la expresión de una actitud asumida por los que «sólo tienen razón», por los que ven en el hombre un ente de razón y no un haz de contradicciones." (Ferrater Mora, 1941: 403-404).

Sin pretender dar etiquetas, José Ferrater Mora vuelve a describir el pensamiento de Miguel de Unamuno con sus ángulos existencialistas, que al igual que Kierkegaard se opuso filosofías profesionales como la de G. W. F. Hegel que además se le ubica dentro del imperio de la lógica. En Miguel de Unamuno, el hombre se sitúa desde lo que siente y padece, esto expresa la fundamentación unamuniana contraria al cientificismo racionalista que no logra ser integral en la vida humana concreta, que además está expresado en una dinámica de la existencia 'el hambre de supervivencia y el afán de inmortalidad', tópico que será abordado por varias corrientes existencialistas, por consiguiente el hombre no es en su totalidad un ser o entidad que se deja ser llevado por la razón.

De acuerdo a José Ferrater Mora, la filosofía unamuniana es un bloque de contención contra el cientificismo y el racionalismo:

"El cientificismo y el racionalismo son el camino que conduce al suicidio, la actitud adoptada por quienes, en su afán de teología, «esto es, de abogacía», o en su invencible odio antiteológico, no advierten en la contradicción, y por consiguiente, en la sinrazón, el verdadero modo de pensar y de sentir del hombre existencial. El fundamento de la creencia en la inmortalidad no se encuentra en ninguna construcción silogística ni en ninguna inducción científica: se encuentra simplemente en la esperanza. Pero la inmortalidad no consiste a su vez para Unamuno en una pálida y desteñida supervivencia de las almas. Vinculándose a la concepción católica, que anuncia la resurrección de los cuerpos, Unamuno espera y proclama «la inmortalidad de cuerpo y alma» y precisamente del propio cuerpo, del que se conoce y sufre en la vida cotidiana." (Ferrater Mora, 1941: 403-404).

Miguel de Unamuno vuelve al tópico existencial, calificando el cientificismo y el racionalismo como conductores del suicidio, es decir, el cientificismo y el racionalismo son equivalentes a la muerte y se contrapone a la visión dinámica de la supervivencia del individuo y el ser. Y del mismo modo califica a las posturas teológicas y silogísticas que son deterministas a la hora de conceptualizar al hombre y su ansia de inmortalidad sin considerar que la determinación del hombre en la supervivencia está basada en algo simple, la esperanza. La esperanza como motor en la dinámica existencial, la esperanza como una semblanza de los sentidos existenciales. 
Y esta visión de la trascendencia del individuo nada tiene que ver con la resurrección de las almas o los cuerpos, sino habla de la inmortalidad de cuerpo y alma que se va transformando y no se detiene en la muerte teológica o en la muerte cientificista.

José Ferrater Mora prosigue abordando el tema de la esperanza en Miguel de Unamuno al exponer:

"Esta esperanza, velada en la mayor parte de concepciones
filosóficas por nebulosas míticas y por sutiles sistemas, es rastreada
por Unamuno en los numerosos ejemplos de la sed de inmortalidad,
desde los mitos y las teorías del eterno retorno hasta el afán de gloria
y, en última instancia, hasta la voz constante de una duda que se
insinúa en el corazón del hombre cuando éste aparta como molesta la
idea de una sobrevivencia. Demostración o refutación, confirmación o
negación son sólo, por consiguiente, dos formas únicas de
racionalismo suicida, a las cuales es ajena la esperanza, pues ésta
representa simultáneamente, como Unamuno ha subrayado
explícitamente, una duda y una convicción." (Ferrater Mora, 1941:
403-404).

A pesar de que la naturaleza de las consideraciones de Miguel de Unamuno expuestas por José Ferrater Mora cae en cierta contradicción, y es si quiere natural, demostración-refutación, confirmación-negación, ya que las posturas desde lo teológico y lo racionalista tienden a ser reduccionistas. Ambas posturas se distancian de la esperanza, cualidad que está intrínseca en el corazón del hombre.

Ahora bien, si se hace referencia a la influencia orteguiana se deberá rescatar lo que el mismo Ferrater Mora expusiera en la entrevista de Teorema (1972) en referencia directa a quién será una de sus principales influencias durante una etapa de su vida:

"T.: Nos agradaría ofrecer a los lectores de TEOREMA un breve juicio tuyo sobre la obra de Ortega y los aspectos de su pensamiento que consideras más vigentes. ¿Te es posible hacerlo?

F.: Lo haré, como se me pide, brevemente. Como a todos los miembros de mi generación, Ortega me influyó grandemente; para nosotros era una bocanada de aire fresco. Luego, durante mucho tiempo, me pareció que había en él (o en su obra, lo único que de él conozco) aspectos bastante irritantes: el «dejarme solo, a ver lo que hago», el preciosismo inútil, etc. Creo que hoy día es menester ser más objetivo. Creo que lo que de Ortega hubiese podido influir sobre mí ya pasó, y hace mucho tiempo, pero esto es otro asunto. Lo que debe reconocerse hoy es el papel histórico de Ortega en la formación de la cultura española de nuestro siglo, y también la vigencia de buen número, de preocupaciones suyas, en particular la preocupación por un estudio de la realidad de los hombres y de sus producciones reales en un mundo real. Todo eso pueden hacerlo asimismo historiadores, 
sociólogos, etc., pero Ortega ha tocado puntos que merecerían revisarse, aun si se adoptaran perspectivas nada orteguianas." (1972: 97-108).

Analizando que en primer término José Ferrater Mora considera a José Ortega y Gasset una importante influencia en él, pero del cual expresa una crítica considerable al manifestar que hay en su obra "aspectos bastantes irritantes" o "el preciosismo inútil", no necesariamente hay una distancia irreconciliable, ya que José Ferrater Mora reafirma la importancia de José Ortega y Gasset en la formación de la cultura española contemporánea y lo vigente de su obra y que sigue considerando debe ser objeto de estudio y revisión.

En la entrevista otorgada a Lola Díaz, que fuera publicada en la revista Cambio 16, proporcionará algunas luces también con respecto a este particular, referente a su formación y la influencia de José Ortega y Gasset entre otros pensadores de su tiempo y previo a éste:

"LD: Usted pertenece a una generación de pensadores que se educaron en el alemán, una tradición que luego se ha roto.

JFM: Esa es una de las cosas que consiguió Hitler, destruir en España el entusiasmo por lo alemán. La cultura alemana literaria y científica de antes de la guerra era fabulosa y el alemán ya empezó a tener influencia en España desde el siglo XIX. Fíjese que uno de los movimientos filosóficos españoles de este siglo fue el krausismo, que venía muy modificado de Alemania. Pero el que inyectó la fascinación por lo alemán fue Ortega, algo que ha influido mucho a la gente de mi generación." (1985: 725).

Además de esta afirmación, es importante considerar lo que el propio José Ferrater Mora reseña en su Diccionario de filosofía sobre lo que el pensamiento de José Ortega y Gasset representa como influencia, no sólo en él, sino en el pensamiento español:

"Característica del período 1910-1923 es el perspectivismo (VÉASE), llevado hasta tales consecuencias que Ortega indica que la substancia última del mundo es una perspectiva. El perspectivismo no es, empero, solamente una doctrina accidental; se convierte en la piedra angular de la teoría del conocimiento. En esta última se opone Ortega por igual al idealismo y al realismo. Contra el idealismo, afirma que el sujeto no es el eje en torno al cual gira la realidad; contra el realismo, que no es un simple trozo de la realidad. El sujeto es una pantalla que selecciona las impresiones o lo dado. No es un ser abstracto, sino una realidad concreta que vive aquí y ahora. Es, por lo tanto, una vida (VÉASE). Tal vida no es sólo biológica; la defensa de lo vital, en la que Ortega insiste ahincadamente, no equivale a la defensa de lo primitivo." (Ferrater Mora, 2004: 2661). 
Se hace notar que José Ortega y Gasset posee una característica, analizada por José Ferrater Mora al situar el pensamiento orteguiano como opuesto al idealismo y de igual manera distante al realismo. José Ortega y Gasset establece que el hombre no es un ser abstracto, sino una realidad que vive aquí y ahora. Es evidente que este "perspectivismo" orteguiano es tributario del existencialismo, incluso se ve cierta cercanía a la visión unamuniana de la existencia.

En consecuencia, el perspectivismo orteguiano hace comparaciones y toma equidistancias absolutistas entre los realismos y los idealismos. Según lo expresado por José Ferrater Mora en el final de la cita que antecede este comentario, la vida no consiste solo en el ser biológico o en la razón biológica, como tampoco reside en lo primitivo, los pensamientos y las perspectivas también son la vida. En el análisis que se realiza en el presente trabajo y que conforma parte de las hipótesis que sostienen a lo largo de la argumentación expuesta, se observará; en el análisis del integracionismo así como en las lecturas a El ser y la muerte y De la materia a la razón; que hay cierta analogía que sitúa la forma del sistema filosófico de José Ferrater Mora, sobre todo en su praxis metodológica, concordancia con el periodo perspectivista de José Ortega y Gasset.

Respecto al perspectivismo orteguiano, José Ferrater Mora sigue expresando:

"Si bien la cultura (VÉASE) es producida por la vida y para la vida -y, por consiguiente, la vida es anterior a la cultura-, ello no significa que los valores culturales sean secreciones de actividades vitales y menos aun meramente biológicas. Significa que los valores culturales son funciones vitales, aunque funciones vitales que obedecen a leyes objetivas, y que, por consiguiente, hay una continuidad completa entre lo vital y lo transvital o cultural. Como consecuencia de esto puede afirmarse que la razón (VÉASE) no está fuera de la vida ni tampoco es la vida, sino una función de la vida." (Ferrater Mora, 2004: 2661)

Es preciso acotar que la denominada cultura como producto de la actividad del hombre, como acción del ser vital, no es algo del todo orgánico; aunque la agricultura sí lo sería en este caso; pero constituye parte de lo inorgánico o como lo define José Ferrater Mora al analizar a José Ortega y Gasset como transvital. Pero lo transvital es parte de la vida, es consecuencia de las acciones del hombre, de sus propias dinámicas sociales.

El perspectivismo no es el único elemento importante en José Ortega y Gasset, como se verá continuación, José Ferrater Mora sigue disertando al respecto:

"El desarrollo de los temas a que le había conducido el perspectivismo lleva, pues, a Ortega a las posiciones que hemos 
calificado con el nombre de racio-vitalismo. Algunas de estas posiciones aparecen claramente en una de las primeras tesis filosóficas de Ortega: la tesis formulada en 1914 según la cual «Yo soy yo: yo y mi circunstancia». Esta tesis había conducido a Ortega a una elaboración del concepto como cultivo de la espontaneidad en que la vida consiste, es decir, a una doctrina del concepto como auténtico «órgano» de conocimiento. En el desarrollo posterior la tesis en cuestión adquiere un papel todavía más fundamental: permite entender la noción de razón vital sobre la cual va a girar su filosofía. Contra la abstracción del racionalismo y contra las interpretaciones pragmatistas, biologistas y exclusivamente intuitivistas del vitalismo (VÉASE), Ortega mantiene que si quiere llamársele vitalista, habrá que entender por tal adjetivo la posición del que afirma que el conocimiento, aunque siendo racional, está arraigado en la vida. Por lo tanto, la doctrina de la razón vital (o razón viviente), el raciovitalismo, desconfía solamente de ciertas interpretaciones dadas a la razón. En particular desconfía de la reducción de la razón a razón física y abstracta y mantiene que toda razón es razón vital. 'Razón' es, pues, un término que designa todos los actos que "dan razón de» y especialmente que dan razón de los hechos vitales." (Ferrater Mora, 2004: 2661- 2662).

El raciovitalismo constituye una forma de pensamiento que toma distancia de la abstracción del racionalismo, pero sigue teniendo un carácter racional aunque equidistante, al menos en parte. Pero igual ocurre contra las interpretaciones pragmatistas, biologistas e intuitivistas relacionadas al vitalismo. En otras palabras, el raciovitalismo no es una doctrina reduccionista y evita los absolutismos.

Según José Ferrater Mora, comentando sobre la visión de José Ortega y Gasset, el raciovitalismo no es sólo un método filosófico:

"Por eso la filosofía no es un pensamiento acerca de la vida, sino un partir del hecho de que toda razón es viviente. En suma: 'razón vital' puede traducirse por 'vida como razón'. De ahi que el hombre no sea para Ortega un ente dotado de razón, sino una realidad que tiene que usar de la razón para vivir. Vivir es tratar con el mundo y dar cuenta de él, no de un modo intelectual abstracto, sino de un modo concreto y pleno. De ello se deriva el saber (VÉASE) como un saber a qué atenerse: el hombre ha tenido que inventar la razón, porque sin ella se sentiría perdido en el universo. Ahora bien, la razón vital no es solamente un método, sino también una realidad: es una guía en el sistema de la realidad y la propia realidad que se guía a sí misma dentro del universo." (Ferrater Mora, 2004: 2662).

En las consideraciones expresadas por José Ferrater Mora acerca del pensamiento orteguiano, es digno de mención que el saber en el hombre no constituye un elemento derivativo de la razón, sino de la realidad. La razón es parte de la realidad, pero una parte que en todo caso deriva de la vida misma, no una simple abstracción. 
Es importante reseñar otro de los filósofos mencionados al principio de esta consideración, como referencia importante en el filósofo barcelonés, el pensador Eugenio d'Ors, el cual quedó plasmado en el Diccionario de filosofía de José Ferrater Mora como a continuación se vera:

\section{“D’ORS, EUGENIO (EUGENIO ORS ROVIRA)}

(1882-1954), nac. en Barcelona. Dio numerosos cursos y conferencias en Universidades españolas y extranjeras y fue nombrado, en 1953, profesor de Ciencia de la Cultura en la Universidad de Madrid, en cátedra creada especialmente para él. La primera contribución filosófica importante de d'Ors consistió en un intento de superación del pragmatismo que le condujo pronto a la afirmación de un intelectualismo de nuevo cuño en el cual veía la característica principal de todo el movimiento que con frecuencia llamó el «novecentismo». Tal nuevo intelectualismo se opone tanto al predominio de la mera intuición como al de la razón abstracta." (Ferrater Mora, 2004: 2659-2660).

Es innegable que el movimiento que Eugenio d'Ors llama "novecentismo" tiene una conexión indefectible con el "integracionismo". Cuando una forma de pensamiento "se opone tanto al predominio de la mera intuición como al de la razón abstracta" (Ferrater Mora, 1958: 1010-1011) se percibe que hay una distancia evidente de los dogmatismos y absolutismos, caracterización que se observa en el integracionismo, aunque el novecentismo busca la superación del pragmatismo. No se puede afirmar en concreto que el novecentismo sea el predecesor del integracionismo, pero al menos hay una característica que los acerca y que además conduce a la afirmación de que José Ferrater Mora lo tiene presente a la hora de formular su método filosófico.

Pero la mencionada caracterización del novecentismo no es el único elemento presente en Eugenio d'Ors de acuerdo a lo que acota José Ferrater Mora:

"El órgano de captación de la realidad resulta ser así la inteligencia (seny), igualmente equidistante de las concepciones formalistas y de las concepciones empírico-sensibles (alejado, en los términos del autor, tanto de la «logística» como de la «fenomenología»). Primer resultado de estas investigaciones fue una «filosofía del hombre que trabaja y que juega» en la que desempeña un papel fundamental la teoría del yo como libertad opuesta a una resistencia que lo constituye, teoría ligada a la afirmación religio est libertas." (Ferrater Mora, 2004: 2660).

Se observa en la descripción anterior por parte de José Ferrater Mora, otro rasgo que acerca al pensamiento de Eugenio d'Ors al integracionismo, la equidistancia que asume de las concepciones formalistas y de las empírico-sensibles. Eugenio d'Ors no es un empírico 
en el estricto uso del término, pero tampoco asume que su novecentismo sea una categoría intelectual alejada del empirismo, sin que eso determine en sí mismo que no recibe su influencia. Incluso toma equidistancia de acuerdo a la apreciación de José Ferrater Mora de la fenomenología.

Hay otras consideraciones del pensamiento de Eugenio d'Ors que se ven reflejadas en el análisis de José Ferrater Mora:

“A través de estos trabajos y de numerosos artículos y libros se
constituyó un sistema más amplio que al principio comprendía la
dialéctica, la física o tratado de la Naturaleza y la poética o tratado
de la creación, pero que luego se articuló en las tres partes siguientes:
dialéctica, poética y patética. La dialéctica es el órgano general o
novísimo Organon (VÉASE) de la doctrina. La dialéctica se basa en el
diálogo y en la ironía, y contiene una teoría de los principios
destinada a efectuar una «reforma kepleriana de la filosofía». Estos
principios son el de función exigida y el de participación." (Ferrater
Mora, 2004: 2660).

Es la revisión de la obra completa de Eugenio d'Ors lo que permite a José Ferrater Mora establecer que la dialéctica es la clave inicial del sistema de pensamiento y doctrina que daría como producto el novecentismo. En posterioridad, se le agregarían otros elementos, poética y patética. Es razonable intuir que a este respecto hay una diferencia con José Ferrater Mora, ya que la ironía y el patetismo no se observa a menudo en la obra filosófica de José Ferrater Mora, o al menos hasta ahora, entre los estudiosos del pensamiento ferrateriano, incluyendo a Carlos Nieto Blanco, hay referencia de la presencia de esos elementos de forma regular o constante.

A pesar de ese detalle que animaría a considerar que José Ferrater Mora no hizo ningún calco o simulación del pensamiento de Eugenio d'Ors, en la cita que antecede este comentario encuentra asimismo otra cercanía al integracionismo por parte de Eugenio d'Ors y es el componente dialéctico. Es imperante recordar que José Ferrater Mora en $E l$ ser y la muerte describe al integracionismo como "empirismo dialéctico", que si bien es cierto hay una influencia de Hegel, se verá también presente en Eugenio d'Ors.

Y es que José Ferrater Mora cuando analiza y confronta sistemas de pensamiento opuestos, antagónicos, busca "tender puentes" y está, en consecuencia, estableciendo un diálogo, aunque dicho diálogo esté lejos o cerca de establecer una síntesis o de confrontar tesis y antítesis. $\mathrm{Y}$ en esto coincide con Eugenio d'Ors ya que un diálogo es una participación, uno de los principios del novecentismo, y estas peculiaridades pueden 
incluso, situar al integracionismo en un diálogo donde participan constantemente los sistemas de pensamiento o corrientes que se definen o que establecen contradicciones y que dichas contradicciones al hacerse partícipe de ese diálogo, se reitera, el diálogo es participación y de eso se trata la dialéctica. El diálogo también es integración, es la búsqueda de la participación de los antagonismos y absolutismos presentes en diversas corrientes y sistemas de pensamiento.

Es necesario considerar otros principios del pensamiento de Eugenio d'Ors, elementos que ayudan a precisar el resto de la influencia que ejerció en José Ferrater Mora:

"El primero sustituye al principio de razón suficiente y consiste en suprimir, en el vínculo entre dos acontecimientos, las exigencias de procedencia causal y de equivalencia cuantitativa. El segundo sustituye al principio de no contradicción y consiste en afirmar que todo ser participa de la realidad de otro. La aplicación de estos principios hace comprender, según el autor, el carácter peculiar del pensamiento figurativo (cuyo modelo es el dibujo, equidistante de la cifra y de la pintura, de un modo análogo a como la reforma kepleriana consiste en proponer la elipse como figura equidistante entre el círculo perfecto y puramente racional y el movimiento irregular y completamente irracional)". (Ferrater Mora, 2004: 2660).

Se destaca la sustitución del principio de no contradicción por el de la participación. En el pensamiento de Eugenio d'Ors es afín a integrar contradicciones. Integrar es participar, participar como principio de integración. Es el mismo diálogo que el "empirismo dialéctico" hace al comparar e integrar conceptos-límite, al no permitir que se interpongan las contradicciones o que prevalezcan los antagonismos.

Para este momento, se presenta una interrogante: ¿Cuál es la finalidad del pensamiento de Eugenio d'Ors? José Ferrater Mora acota:

"De este modo se consigue, como dice el autor, la colonización de Pan por medio del Logos, colonización que se ejecuta en diversos terrenos: en la física, por las leyes; en la historia, por el primado de las constantes o «eones» sobre los períodos; en la vida humana, por el predominio de los ritmos, entendidos como estados y no como cronologías. Este modo de operación de la inteligencia (figurativa), opuesta a la razón y a la irracionalidad, se advierte asimismo en la poética y en la patética. La poética es en buena parte un desarrollo de la filosofía del hombre que trabaja y que juega; la patética comprende principalmente la cosmología. Destacados desarrollos de la poética son la angelología (teoría de la sobreconciencia o personalidad) y la ciencia de la cultura, con la investigación de las constantes y de los estilos." (Ferrater Mora, 2004: 2660). 
El pensador catalán destaca que este ejercicio filosófico de Eugenio d'Ors, es una experiencia lúdica, al afirmar que la poética dentro de la filosofía del hombre es una manifestación del hombre que juega y que trabaja. En otras palabras, trabajar y jugar también es participar, ya que se establece una dinámica y un diálogo, trabajo-juego, que además permite la participación de otros principios (patética) que hace prevalecer el diálogo entre la razón y la irracionalidad.

En reflexiones finales a este respecto, la cercanía metodológica y hasta discursiva en Eugenio d'Ors puede ser un precedente del "empirismo dialéctico" o integracionismo. Es evidente que hay distancias, que implicarán diferencias de orden ontológico y de formas conceptuales.

Pero todo esto no deja a un lado el reconocimiento que José Ferrater Mora manifiesta al analizar el novecentismo como intento de superación del pragmatismo, pragmatismo que domina no solo en la filosofía, sino también en otras áreas del saber académico, científico, político y en las relaciones sociales.

Las influencias en la formación filosófica de José Ferrater Mora sin duda alguna han forjado un carácter particular, la impronta histórica se refleja en la manera en que el pensador barcelonés elaboró su obra filosófica y enciclopédica, en particular su Diccionario de filosofía, que registra no únicamente la importancia de la historia de la filosofía universal, sino además el compendio de pensadores que ejercieron una significativa influencia en el resto de su obra, en la elaboración de su sistema o método filosófico, que está lleno de perspectivas, con su respectiva poética, ontología y hasta una lúdica que lo trasciende a lo que llamó Carlos Nieto Blanco la filosofía en la encrucijada, una encrucijada en la que José Ferrater Mora sigue en tránsito vital, que va de la materia a la razón, donde todo no termina en la muerte, ya que la muerte para él es solo cesación, pero no el final del camino.

6. Contexto social que influencia la vida y obra de José Ferrater Mora.

6.1. Guerra civil y exilio.

Tras la derrota que sufriera el bando republicano español enfrentado a las fuerzas militares que encabezara el general Francisco Franco, por un lado se puso fin a la guerra 
civil pero además se arrojó al exilio a un extraordinario grupo de hombres y mujeres, quienes se vieron obligados a emigrar con destino a otras tierras para hallar asilo y refugio.

Todo ello motivo que el presidente de Chile para ese entonces, Pedro Aguirre Cerda, líder del Frente Popular, comprometiera los esfuerzos del Estado chileno para apoyar y financiar el traslado de un número importante de refugiados españoles, reafirmando así su solidaridad hacia el pueblo español y de alguna forma dándole carácter universal a la causa republicana.

En sintonía con tales propósitos, Aguirre Cerda designó cónsul delegado para la inmigración española en París a Pablo Neruda, en pro de que se hiciera cargo de la organización y posterior ejecución del traslado de miles de españoles que se encontraban prisioneros en los campos de concentración del sur de Francia.

La tarea de Neruda fue fructífera y el 4 de agosto de 1939 permitió que zarpara el barco carguero Winnipeg desde el puerto francés de Poullac con rumbo a Valparaíso. En este navío se trasladaron más de 2 mil 200 refugiados, quienes arribaron a Chile el 3 de septiembre de ese mismo año, trayendo consigo un contingente de pasajeros que resulto ser muy diverso, representando todo el espectro ideológico español y de sus distintas regiones, así encontramos: socialistas, anarquistas, republicanos, comunistas y nacionalistas; vascos, catalanes, valencianos, gallegos, madrileños y andaluces. A los cuales unía un sentimiento común, el arraigado compromiso de compañerismo y solidaridad que se hace presente en tiempos de guerra, así como también, según dan cuenta diversos testimonios y entrevistas, las profundas convicciones antifascistas.

La realidad es que al igual que muchos pensadores de su tiempo José Ferrater Mora se unirá a las filas de la lucha en medio de la Guerra Civil española, su creciente interés político y sus capacidades comunicativas a raíz de su facilidad con los idiomas le permitieron dar su apoyo en pro de la fuerza republicana.

En la visión de Juan Marichal en su ensayo "El pensamiento español transterrado (1939-1979)" (1982), deja por sentado la diferenciación que es necesario hacer para con la experiencia vivida por los españoles que les tocó emigrar en 1914 y los que les tocó hacerlo cercano a 1931. Marichal sostiene que habrá que tener claro que existe una visible distancia cronológica y anímica entre dos grandes generaciones transterradas de españoles y serán precisamente las que el escritor encuadre en Américo Castro (la de 1914) y la de Francisco Ayala y José María Ferrater Mora (que será la del 31'). Marichal comenta: 
"Porque no sería exagerado decir que la violencia de 1936 fue para la generación de 1914 la negación sangrienta de todos sus sueños colectivos: e incluso podría afirmarse que la generación de 1914 -la de Américo Castro, Ortega, Azaña, etc.- tuvo un agudo sentimiento de culpabilidad colectiva. [..] La generación de Ayala y Ferrater, la de 1931, vivió, en cambio, la guerra en forma muy diferente: en primer lugar, la padeció directamente en los campos de batalla. Pero, sobre todo, no podía considerarse a sí misma responsable de la catástrofe de 1936: fue, más bien, la gran víctima colectiva de la cultura española en aquella contienda" (1982: 10)

Es así como el autor considera que ambas generaciones de españoles emigrantes experimentaran su vida en el exilio, las cuales representarán en sí mismas experiencias muy disimiles de la vida colectiva española al tiempo que manifestarán estados de ánimo intelectual muy distantes.

Centrándonos en la experiencia de José Ferrater Mora, encontramos que después de su culminación de estudios universitarios, estalla en el año 1936 la Guerra Civil española, siendo Ferrater Mora un militante y partidario del bando republicano, ejército en el que se alistó, es enviado al Frente del Este, adonde estuvo enfermo y recuperándose por cuatro meses en un sanatorio en Los Pirineos, pese a ello siguió prestando servicio en el mismo en labores de inteligencia, cuerpo en el que servirá hasta su involuntaria salida de su España originaria, dado que con la caída del Frente del Este y la conclusión de los enfrentamientos su paso al exilio fue prácticamente obligatorio.

Vale destacar que precisamente fue su condición de salud la que lo llevará a que le dieran una posición especial en la Sección de Inteligencia de la Jefatura Avanzada del Ejército Leal de Oriente, donde al final de la guerra se verá envuelto en la lucha que luego marcará su vida, puesto que se convirtió en un férreo opositor al régimen de Francisco Franco, todo ello a pesar de que como lo reseñara Carlos Nieto Blanco "no existen estudios específicos sobre su posición respecto a cuestiones sociales y políticas y, menos aún, sobre su participación en la resistencia al régimen dictatorial franquista" (2010: 126).

Hecho que muy probablemente le benefició pues como afirma Roberto Dalla Mora (2014: 127) a causa del mismo estilo de José Ferrater Mora, elegante y amable, con una tendencia a criticar de forma irónica y muy sutil, sea a lo que seguramente responda que no se le ha querido ver a él ni a su pensamiento y obra una real oposición al régimen de Francisco Franco. Con lo cual, a diferencia de lo que experimentaron otros pensadores de 
la época del exilio, durante los años de los tiempos de dictadura, la obra de José Ferrater Mora tuvo difusión en España, aunque indiscutiblemente parcial.

A partir del año 1939 cruza la frontera hispano-francesa cuando Cataluña está ocupada por las tropas de Francisco Franco. Arranca de esta forma su proceso de exilio, y será en París donde viva los tres primeros meses de las cincuenta y dos navidades que estará alejado del suelo español.

Sobre la Guerra Civil española, el escritor catalán compartió algunas breves palabras, siendo entrevistado por Lola Díaz (1985), parte de las cuales son compartidas a continuación:

"LD: Durante la guerra civil usted emigra a Cuba, luego vive en Chile y finalmente se instala en los Estados Unidos con treinta años. ¿Fue una etapa dura?

JFM: A mí, la guerra civil me pilló cuando yo tenía veintitrés años. Yo nací en mil novecientos doce, según me han contado, y esas cosas convienen creérselas, así que cuando estalla la guerra yo estaba en Barcelona, con el Ejército republicano. Primero me marché a Francia y desde allí me agenciaron un visado para La Habana como actor de la compañía teatral española Díaz Collado.

LD: Sin embargo, usted no era actor...

JFM: En absoluto. En La Habana empecé dando conferencias, escribiendo y haciendo la primera edición de mi Diccionario de filosofía.

LD: ¿Qué es lo que más le impresionó de Cuba?

JFM: El calor. Yo soy una persona muy adaptable a la que le importan muy poco las diferencias culturales. Cuando llegué a La Habana, lo primero que pensé es ver lo que podía hacer para salir adelante. Estuve dos años en Cuba, pero me pesaba bastante el calor, así que me fui a dar unos cursos en la Universidad de Santiago de Chile, donde el clima es bastante benigno. Allí me quedé seis años y fue una época muy interesante desde el punto de vista erótico. En mi novela «Claudia, mi Claudia» hay una serie de relatos amorosos que transcurren en Chile, y aunque no son exactamente autobiográficos, sí que tienen que ver con mis experiencias." (1985: 725).

La guerra marcó una gran influencia en su vida literaria. Pues para el año 1945, en la culminación de la Segunda Guerra Mundial, logrará en Argentina imprimir su brillante obra Cuatro visiones de la historia universal en la Editorial Losada, Cuestiones españolas en Colegio de México y Variaciones sobre el Espíritu en la editorial Suramericana de Buenos Aires. 
El transcurrir del año 1946, en la editorial Cruz del Sur de Chile le publican $L a$ ironía, la muerte y la admiración, obra con una considerable carga existencial, y es en 1947 cuando aparece El sentido de la muerte, impresa en Buenos Aires por editorial Suramericana. Esta obra es la que inicia el origen de su propio sistema filosófico, proponiendo un método: el integracionismo, que luego desarrollará con más profundidad en su reelaboración y reescritura de esta obra en la posterior El ser y la muerte: bosquejo de una filosofía integracionista. Sin embargo, el integracionismo seguirá siendo un tema recurrente en otras obras que complementan su sistema filosófico. Legado éste que será analizado más adelante.

Otro elemento de capital importancia, al momento de apreciar la trayectoria vital del pensador catalán José Ferrater Mora, resulta ser el insoslayable periodo de su luengo exilio. Situación que marcaría el resto de su existencia. Sentirse obligado abandonando la patria para de inmediato incorporarse al grueso número de ciudadanos españoles que partían hacia países vecinos -en su caso hacia tierras francesas-, pretendiendo un futuro inmediato lejano a la represión y la barbarie instaurada por el régimen totalitarista del general Francisco Franco.

Tal como lo reseñará Roberto Dalla Mora en su disertación titulada Aproximación a la presencia de José Ferrater Mora en España tras la Guerra Civil (1952-1980) y que fuera presentada como parte del I Congreso internacional de la Red española de Filosofía, José Ferrater Mora perteneció a la generación de los pensadores españoles que tuvieron que exiliarse de España por su implicación durante la Guerra Civil española en el bando republicano (2016: 30).

Junto con otros pensadores le correspondió hacer vida fuera de su natal Barcelona. Ubicados los protagonistas de tales penurias se precisa determinar el contexto donde se desarrolló tan nefasto suceso, para ello se extrae una nota a pie de página de la Revista Anthropos, número 49, página 29, en la que se señala:

"Elías Díaz, en la p. 8, nota 3, de su obra Notas para una historia del pensamiento español actual (1939-1973), Edicusa, Madrid, 1974, dice, apoyándose en Gonzalo Torrente Ballester (Tajo, Madrid, 3 de agosto de 1940) «que los intelectuales exiliados representaban aproximadamente el noventa por ciento de la intelligenzia española» y documenta este porcentaje sobre los datos suministrados por la obra de Darío Puccini, Romancero della resistenza spagnola, Feltrinelli, Milán, 1960, pp. 38 y 70, que son los siguientes: "Se ha calculado que partieron para el exilio 118 profesores de la 
Universidad, 200 de Enseñanza Media y 2.000 maestros». Por otro lado, en las pp. 16-18 de la citada obra de Elías Díaz se proporciona una amplia lista de personas del mundo de la política, de la literatura, de la ciencia, de la filosofía y la pedagogía que escogieron el camino del exilio." (1985: 29).

Juan Marichal, quien como ya hemos hecho mención es uno de los muchos intelectuales que mantuvieron una relación de profunda amistad con José Ferrater Mora, en su obra El pensamiento español transterrado (1939-1979), describió a Ferrater Mora con las siguientes palabras:

"Es el autor de la obra individual más extraordinaria de la cultura transterrada española, un monumental Diccionario de Filosofía cuya primera edición impresa en España (la sexta) apareció en 1979 en Madrid: cuatro mil páginas en cuatro volúmenes. [...] Nada humano, culturalmente hablando, es ajeno a Ferrater: y puede decirse, sin exageración alguna, que Ferrater es el español con más lecturas de todo el siglo XX. Su cultura es, en suma, mucho más amplia y, sobre todo, más disciplinada que la de la generación de sus maestros españoles, la de 1914; y no sería arbitrariedad decir que Ferrater Mora representa -como ningún otro escritor o pensador español- la universalidad del alma española que anunciaba Darío en 1904" (1982: 13).

Juan Marichal hace referencia que en efecto es conocido que José Ferrater Mora supo aprovechar de la mejor manera de su situación y circunstancia durante su tiempo de exilio, dado que entró en contacto con un mundo académico y un contexto intelectual que indudablemente ampliaría y enriquecería su gran bagaje cultural, y que se reflejaría en su obra, particularmente en su texto más conocido como fue el Diccionario de filosofía.

Como ocurrió con la mayoría de los intelectuales españoles republicanos, el arranque del exilio de José Ferrater Mora empezó justo después de la derrota del Ejercito Republicano en el año 1939.

Julio Ortega Villalobos en un ensayo para El Basilisco, afirma que:

"según José Ricardo Morales, dramaturgo y exiliado que llegó a Chile a bordo del Winnipeg, (la derrota) obligó dramáticamente al bando republicano a optar por una de estas tres alternativas: 1) estar enterrado; 2) permanecer aterrado o 3) vivir desterrado. José Ferrater Mora optó por la tercera opción” (1996: 86).

Un grueso número de españoles padecieron similar viacrucis; un destino sombrío cubría la madre patria, la mejor opción sería postergar los sueños y escapar a la pesadilla. En la anteriormente referida revista Anthropos, se reseña que la vida de José Ferrater Mora, en síntesis: 
"Como la de otros muchos españoles, experimentará un giro definitivo. Tanto su actividad académica como filosófica se realizarán fuera de España. Ferrater será un exiliado español, un exiliado más de la última crueldad fratricida de este siglo. Después de una breve estancia en Francia se embarca para La Habana en donde traduce y enseña de forma irregular. Allí prepara la primera edición de la que con el tiempo será su obra más conocida, el Diccionario de filosofía, sobre cuya importancia tendremos ocasión de hablar en un próximo capítulo. En 1941 se traslada a Chile, país en el que permanecerá hasta 1947, siendo profesor de filosofía en la Universidad de Santiago. A partir de 1947, por mediación de la Fundación Guggenheim, Ferrater Mora se instala en los Estados Unidos, país en el que culminaría su vida académica. Aunque ha sido lector y profesor visitante de varias universidades norteamericanas como Princeton, Kansas, Johns Hopkins, Emory y Temple, desde 1949 hasta su jubilación en 1981, ha venido ejerciendo como profesor de filosofía en el Bryn Mawr College (Pennsylvania).” (Anthropos. No. 49. 1985: 28).

Al igual que ocurrió con la mayoría de los intelectuales españoles republicanos, el arranque del exilio de José Ferrater Mora empezó justo después de la derrota del Ejercito Republicano en 1939. Su exilio arrancó en Francia, donde tras pasar unos pocos meses, lo llevó a residenciarse primero en Cuba, específicamente en la ciudad de La Habana, donde ejercerá como docente y conferencista, dictando varios cursos en centros de educación como la Universidad de La Habana, Club Liceo, el Instituto Cubano-Hispano de Cultura, Colegio Libre de La Habana, El Ateneo, entre otros, además hará traducciones, enseñará en cursos de verano y desarrollará su actividad literaria de mayor exigencia, como fue preparar la primera edición del Diccionario de filosofía.

Luego partirá en el año 1941 y hasta el año 1947 a Chile, para asentarse en su capital Santiago de Chile. Su viaje a la ciudad austral, se gestó mediante el apoyo de Alfonso Rodríguez Aldave, marido de María Zambrano y ex secretario de la embajada de España en Chile, quien le propuso en La Habana (Cuba) trasladarse al sur, para ello le entregó unas cartas de recomendación a fin de que se las diese a conocidos e influyentes directores de periódicos chilenos con el propósito de buscarle una ocupación profesional de acuerdo a su mérito intelectual.

Según llegaron a testimoniar allegados al filósofo barcelonés: a partir de 1941 y hasta el año 1947, logra asentarse en Santiago de Chile, Chile. Estadía marcada por dos situaciones disimiles a un extremo consigue realizar una importante producción intelectual, y por el otro totalmente aparte al anterior: estuvo sumamente enfermo y en una situación 
precaria que hasta vómitos de sangre logró producirle, cuadro de salud del que fue salvado por transfusiones de sangre, situación que se alivió gracias a aportes de otros exiliados.

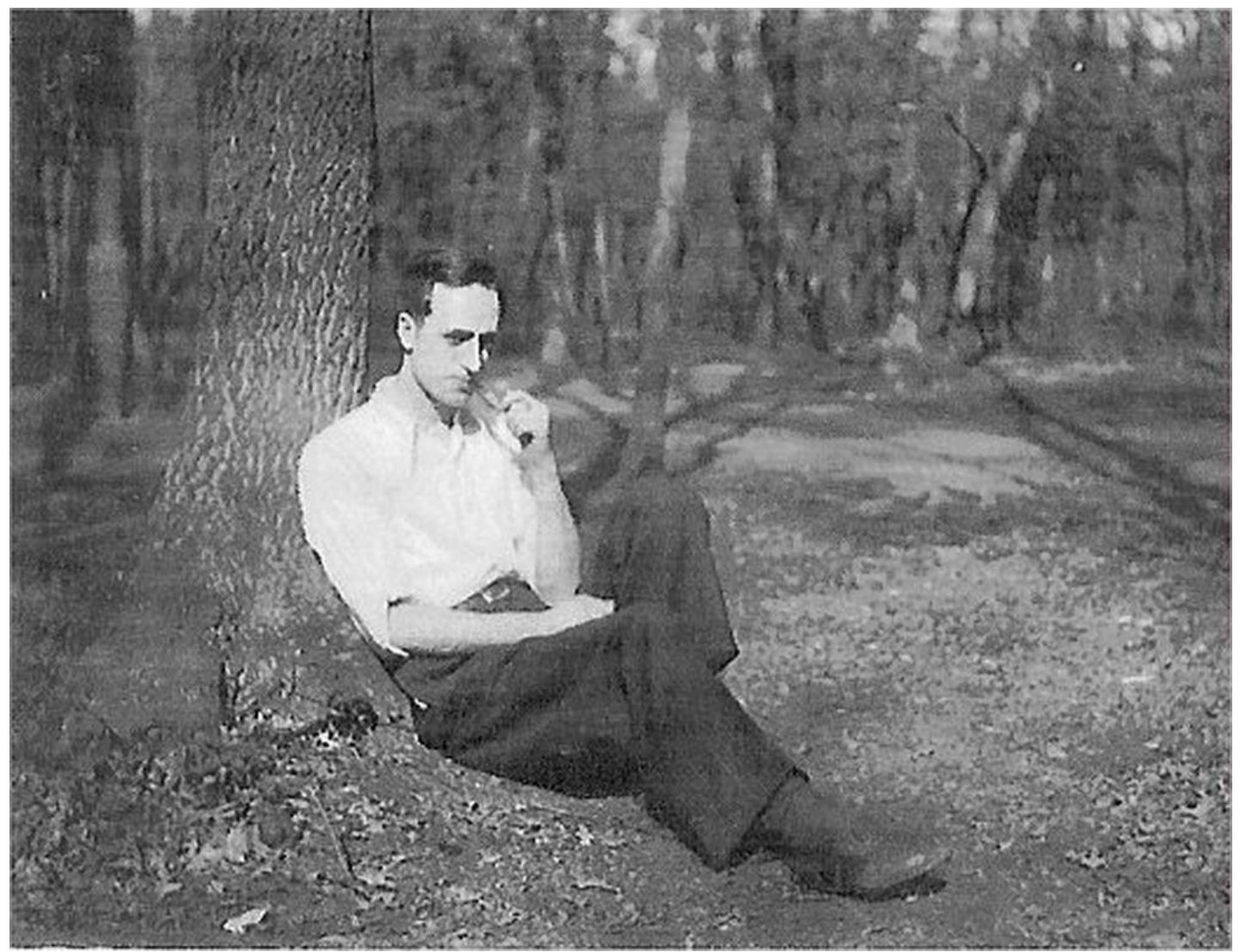

Ilustración 9: José Ferrater Mora en su juventud

(Fuente: Citado por Bardera Poch, D. (2015) Josep Ferrater Mora: de filòsof a narrador. [Entrada en blog] Site ara.cat. Tomado de: http://www.ara.cat/comarquesgironines/Josep-Ferrater-Mora-filosofnarrador_0_1349265077.html).

Como recompensa ante tan duros momentos, estando en la Republica chilena consigue publicar para España y Europa, el conocidísimo volumen: Les formes de la vida catalana (1944) y un año más tarde editado por el Colegio de Médicos publica Cuestiones españolas (1945), en estos se tratan aspectos de tipo social y político español, que indican cómo a pesar de su exilio y las múltiples adversidades, su interés por lo ocurrido en la península es permanente.

Culminaría su producción intelectual en Chile con el libro Helenismo y cristianismo, publicado bajo el apoyo editorial de la Universidad de Chile, durante el año 1949. Indudablemente, Chile marcó un hito y una experiencia que influyó de forma determinante 
en el resto de su vida y obra. Además de subrayarse como digno de mención en su estadía chilena, su labor en el ejercicio docente a nivel universitario.

Serán precisamente los ya expuestos problemas de salud, los cuales ya arrastraba desde La Habana, Cuba; y que se conoce por referencia dado que allegados del escritor aseguran que nunca logró adaptarse al clima insular, aunado al escaso ambiente cultural y, en especial, los serios problemas económicos que padeció, todo ello motivará su traslado a Chile, donde por un lado aliviará su precaria realidad económica, pero además este país le ofrecía una interesante vida cultural, social, intelectual y política.

Especial interés le ofrecerá el sistema de gobierno, dado que Chile se diferenciará del resto de los países iberoamericanos por su tradición democrática. El Frente Popular, aunado a la reacción del gobierno chileno que abiertamente se opuso al alzamiento militar de Francisco Franco, la postura que asumieron ante la Guerra Civil española, el apoyo en el traslado de exiliados en el barco Winnipeg por mediación del poeta Pablo Neruda, se alzaron como los elementos que evidenciaban la madurez constitucional de que gozaba el país sureño.

Pero la realidad es que para José Ferrater Mora la cultura chilena era positiva. A pesar de la distancia geográfica que existe con Europa, afirmó que "Chile era uno de los países más desarrollados, culturalmente, de América" (1992). A su llegada al país austral, conoce a Juan Gómez Millas, rector de la Universidad de Chile, si se quiere la más importante del país, quien le invitó a colaborar en la restructuración de los planes de estudios. Se relacionó además con Jorge Millas, uno de los pensadores más notables que ha tenido Chile y a quien le hizo una crítica de su libro La idea de la individualidad (1941), a través de un artículo que tituló Sobre un libro de filosofía, publicado en la revista Atenea, el año 1943.

$\mathrm{Su}$ estancia en Chile también le permitirá relacionarse con Enrique Molina, destacado filósofo y rector de la Universidad de Concepción. Gracias a él, pudo publicar en la revista Atenea, donde también escribieron otros pensadores e intelectuales españoles como María Zambrano, Augusto Pescador, Francisco Álvarez González y Eleazar Huerta.

Entre las actividades que desarrolló José Ferrater Mora en Chile se ha encontrado que colaboró activamente en la editorial Cruz del Sur, la cual fue fundada en 1942, junto a intelectuales españoles en el exilio: Arturo Soria, José Ricardo Morales, Mauricio Amster y algunos escritores chilenos como José Santos Vera, Manuel Rojas, Mariano Latorre, 
Pedro Prado, Ricardo Latchman y Juvencio Valle. Nicho en el cual desde una misma perspectiva histórica y cultural, marcada por el desgarro de la Guerra Civil española y del exilio, estudian y potencian los temas que afectan a España, América y a sus propios intereses culturales.

Cruz del Sur se diferenciará por la visión humanista que irradiaba frente a otras empresas editoriales que fueran llevadas a cabo por los exiliados españoles en el continente americano. Su director era Arturo Soria, y estaba estructurada en doce colecciones. José Ferrater Mora dirigió dos de ellas: Razón de Vida y Tierra Firme.

Según reseña la casa editorial en su sitio web la colección Razón de vida pretendía, mediante la publicación de una serie de pensadores hispánicos, terminar con el prejuicio que indicaba que no había filósofos en español.

José Ferrater Mora para ilustrar el norte literario de dicha colección afirmó que la filosofía hispánica se encontraba en otro tipo de escritos, donde vida y pensamiento son imposibles de separar (sf). Esta colección proyectó publicar libros de Abengabirol, Julián Marías, Ramón Llul, Juan Luis Vives y Benito Pérez Galdós, entre otros.

Por su parte, la colección Tierra Firme se proponía destacar del pensamiento universal de todas las épocas, dando espacio a aquellas obras en las que se defienden esas cosas frágiles que están constantemente zozobrando y que en nuestros días bracean desesperadamente para no hundirse: el respeto a la verdad, la tolerancia humana, la libertad de la persona (Cruz del Sur, 1942).

Sin duda, su estancia en Sur América marcó un hito y una experiencia que incluyo de forma determinante en el resto de su vida y obra. Julio Ortega Villalobos cita en un ensayo para El Basilisco (1996: 86-89) como el mismo José Ferrater Mora rememoraba ese tiempo: "De aquella época, arrancaron muchas cosas que fructificaron luego. Mi residencia en Chile fue una etapa significada y significativa de mi obra, y una además, que recuerdo con particular cariño".

Digno de mención en su estadía chilena fueron los aportes que como docente hiciera. Tal como destaca Julio Ortega Villalobos:

"en calidad de profesor, impartió clases en la Universidad de Chile, Universidad Técnica Santa María, Universidad de Concepción y Universidad Católica, de Santiago. En la primera se hizo cargo de las asignaturas de filosofía moderna y lógica. También dictó cursos y conferencias en la Sociedad de Amigos del Arte, Sociedad de 
Escritores de Chile, Sociedad Pro-Arte de Viña del Mar, Centro Catalán, y otras instituciones destacadas. Por otro lado, algunos profesores chilenos, especialistas en lógica, como Manuel Atria Ramírez, sostienen que Ferrater fue uno de los pioneros a la hora de introducir la lógica simbólica en Chile. Con anterioridad a él, sólo se conocía y estudiaba la lógica aristotélica. Su contribución fue decisiva en el desarrollo y conocimiento de la lógica formal". (1996: 86-89).

Muy a su pesar tras encontrarse a gusto por su estancia en Chile, se dice que el exilio y el sentirse desterrado, será un factor que determinará su vida y sus preocupaciones intelectuales. Es por ello que la nostalgia y el destierro serán temas que prevalecen durante su estancia, sobre todo en su primera etapa, hecho que le otorgará a su obra (la cual se convertirá en una filosofía muy cultivada) tan alto grado de complejidad, muy propia de un exiliado.

Y es que la nostalgia se asentará en su vida como consecuencia de lo que había perdido, lo que había dejado atrás, tornándose en un vacío en su vida. Su libro España y Europa, publicado en el año 1942, será el mejor testimonio donde se refleja la añoranza y el desgarro por la pérdida de la tierra abandonada.

Las formas de la vida catalana (1944), Unamuno: bosquejo de una filosofía (1944), Cuestiones españolas (1945), La ironía, la muerte y la admiración (1946), y algunos artículos y ensayos, revelarán con la misma intensidad el sentimiento de melancolía.

Su producción intelectual en el país austral culminará con el libro Helenismo y cristianismo, publicado por la Universidad de Chile en el año 1949.

Esta realidad emocional de su producción intelectual será la raíz para dar un giro literario, es así como sus intereses filosóficos sufrirán un cambio significativo. De su preocupación por la filosofía de la historia, que conservará de sus años en Barcelona, dará paso a una filosofía más antropológica y existencial. Lo que para algunos expertos responde al hecho de que su filosofía llegará a convertirse en la propia encarnación de su vida (Ortega Villalobos, 1996: 86-89).

Ya en disposición de marcharse de la austral tierra suramericana y de haber dejado un valioso aporte académico, el escritor catalán desea prolongar ampliación de sus horizontes vitales, tratando de seguir educándose y también de participar de otras experiencias. José Ferrater Mora logra trasladarse a los Estados Unidos de América, país 
donde arribó en el año 1947, tras obtener una beca de la Fundación Guggenheim que le permitirá profundizar su formación académica.

Fue en el año 1949 cuando decidió fijar su residencia en Bryn Mawr, donde había sido contratado como profesor en el Bryn Mawr College, todo ello tras renovar la beca, ese mismo año obtiene un puesto docente en el Bryn Mawr College de Filadelfia, institución donde trabajó y ejerció académicamente hasta jubilarse. Llegó a posicionarse como el director del Departamento de Filosofía de la mencionada institución y su prestigio lo llevó a ser invitado en otras universidades norteamericanas y en otros países, en las que destacan la Universidad de Princeton, Universidad de Baltimore, Universidad de Filadelfia. Paralelamente mantenía su producción intelectual con gran prodigio, ya que su extensa obra seguirá mostrando a lo largo de su existencia que era un pensador incansable.

Durante su residencia en los Estados Unidos de América, ya en el año 1950, vuelve a visitar el continente europeo y no será hasta el año 1952 fecha en que vuelva a pisar tierra española. Varias universidades españolas lo convocan como profesor invitado, entre ellas la Universidad de Madrid; su alma máter: la Universidad de Barcelona y la Universidad de Palma de Mallorca. Como se verá en las siguientes líneas, su producción intelectual fue muy prolífica incluso después de jubilarse en el año 1981 de su labor profesoral en el Bryn Mawr College.

José Ferrater Mora quien vivió cincuenta y dos años lejos de su país natal, en muchas ocasiones durante su exilio tuvo que enfrentar circunstancias adversas, especialmente durante sus primeros años afuera, tiempo en el que padeció de complicaciones de naturaleza económica y también de salud. Sin embargo, supo sortear todas ellas, gracias también al apoyo de familiares, amigos y otros exiliados. Siempre además mantuvo su mirada puesta en España, tal como lo testimonia su abundante conexión a través de correspondencias, la cual mantuviera con amigos y familiares quienes permanecieron en la península.

Estando en los Estados Unidos de América, al correr del año 1950, ya contaba con cierto renombre dentro del mundo académico y filosófico en lengua española, se planteó por primera vez la idea de volver a su tierra natal y, particularmente, a Cataluña.

Su biógrafo Antoni Mora, reseña que José Ferrater Mora tenía férreas ideas en torno a su retorno, evidenciadas en la correspondencia que mantuviera con su gran amigo, el 
poeta Joan Oliver. Sin embargo, será el mismo Joan Oliver quien aconseje a José Ferrater Mora no apresurarse y plantearse una vuelta definitiva a la madre patria.

En la biografía que hacen de José Ferrater Mora en su sitio web oficial se reseña con exactitud que durante sus primeros momentos como exiliado éste se relacionó con Pedro Salinas y muchos otros intelectuales que se encontraban en similar condición. De hecho, rescatan a raíz de una indagación exhaustiva de sus correspondencias y libros, lo que podría significar una posible relación de sucesos en su vida, de la cual se destaca que:

Entre el año 1947 y hasta el año 1948 se establece en Norteamérica como becario de la John Simon Guggenheim Memorial Foundation; viviendo en la ciudad de Nueva York, Estados Unidos de América.

Entre el año 1948 y hasta el año 1949, se le concede la renovación de la Guggenheim Fellowship. Vive en Princeton, Nueva Jersey; sostiene amistad con Américo Castro y luego en Baltimore, Maryland, donde desarrolla amistad con el poeta Pedro Salinas.

A partir del año 1949 y hasta 1980 trabaja como profesor de filosofía y español en el Bryn Mawr College, ubicado Pensilvania.

Paralelamente desde el año 1957 y hasta el año 1958 será además profesor visitante en la Universidad de Princeton, ubicada en Nueva Jersey. Y en 1960 se convierte en ciudadano estadounidense. Entre el año 1960 y hasta el año 1961 es Senior Scholar del Consejo Americano de Sociedades Sabias. Año en el que será Lindley Conferenciante en la Universidad de Kansas.

A partir del año 1962 y hasta el año 1963 ocupa el cargo de profesor visitante en la Universidad Johns Hopkins; situada en Baltimore, Maryland .Al año siguiente será profesor de la Universidad Emory e invitado Especial del gobierno mexicano en el XIII Congreso Internacional de Filosofía.

Durante el año 1967 y hasta el año 1968 es profesor visitante en la Universidad de Temple; ubicada en la ciudad de Filadelfia, en el estado de Pensilvania. Y entre los años 1969 hasta 1974 es director del Programa de Historia y Filosofía de la Ciencia del Bryn Mawr College, en cooperación con la Universidad de Pensilvania y la American Philosophical Society.

Para el año 1971 es presidente del Simposio Internacional de Lógica y Filosofía de la Ciencia en Valencia, España. En el año de 1974 es invitado especial del Primer Congreso 
Nacional de Filosofía, Morelia, México. Año en el cual además pasa a ser el primer beneficiario de la Cátedra Fairbanks en Humanidades en Bryn Mawr College.

El exilio español como consecuencia de la Guerra Civil española, llevó al padecimiento de una crueldad generalizada, presenciándose algunos sectores sociales caracterizados por trayectorias con variedad de elementos reiterados entre uno y otro individuo. Pese a ello, ese tiempo de exilio permitirá en letrados como José Ferrater Mora meditar acerca de España y los asuntos que le son inherentes pero en el plano de un terreno universal, y tal como lo describirá Marichal, Ferrater Mora vendrá a imprimirle su propio sello:

\begin{abstract}
“...Ferrater es el pensador español de nuestro tiempo que ha meditado más profundamente (y más serenamente) sobre la gran encrucijada de este siglo XX. Esto es, Ferrater sitúa el llamado problema de España dentro del problema de la humanidad actual, del problema del mundo. Este problema es muy sencillo: "las amenazas que pesan sobre la humanidad son mayores que nunca, pues una de ellas es la de su propia destrucción, pero también son mayores que nunca las posibilidades de mejoramiento de la humanidad ". Y así Ferrater Mora cree que los españoles pueden desamortizar su pasado si contribuyen por así decir a desamortizar el futuro de todos los seres humanos. De ahí que sienta Ferrater que la fe en un mañana mejor para la humanidad es el mejor camino para luchar contra las manos muertas del pasado español" (1982: 14)
\end{abstract}

\title{
7. Legado intelectual.
}

José Ferrater Mora será, se unió a otros pensadores españoles para convertirse en un destacado escritor, y como se ha señalado con anterioridad, llegar a ser considerado por algunos como el que ostenta la mayor proyección internacional durante el siglo XX.

Se ha indicado, la mayor parte de la vida de José Ferrater Mora transcurrió en los Estados Unidos de América, la influencia ejercida por esta lengua, por esta sociedad, además de su participación en la Guerra Civil española, así como las temporadas migratorias que le trasladaron de su fronteriza Francia, luego a Cuba, sin dejar de considerar su paso por Chile, todo ello aunado al prolongado oficio docente, sin lugar a dudas contribuyeron a formar el gran lector, pensador y escritor, que devino en un gigante intelectual de la pasada centuria.

Generó en toda su trayectoria vital, una óptica sumamente precisa de las necesidades de la filosofía de su época, sus obras indudablemente mantenían en plena forma su 
delicado ejercicio crítico-reflexivo sobre el panorama filosófico en general, así como de su propio método en ocasiones sistema denominado integracionista. Procedimientos que sumados consiguen permitirle el repaso constante sobre temas, áreas y conceptos que a lo largo y ancho de su obra le mantuvieron despierto el más sistemático interés, muy principalmente sobre la ontología y el existencialismo, que concluyen enlazadas en la pertinaz necesidad de la integración de corrientes opuestas, a su vez como la enorme necesidad del estudio del pensamiento ontológico, por encima de otras vertientes del saber.

Al ahondar en los pormenores de su vida, se encuentra que evidentemente la influencia de sus vivencias se dejará sentir en su legado filosófico. Tras adentrarse en el exilio, postrero a su paso por la Guerra Civil española, José Ferrater Mora por primera vez, en el año 1950, viajó a Europa, pero no llegó a España sino hasta dos años más tarde, cuando realizó su primera visita a la ciudad de Barcelona. Las referencias biográficas que se tienen de los anales de su vida dan por sentado que a partir de allí su presencia en su España natural será siempre intensa.

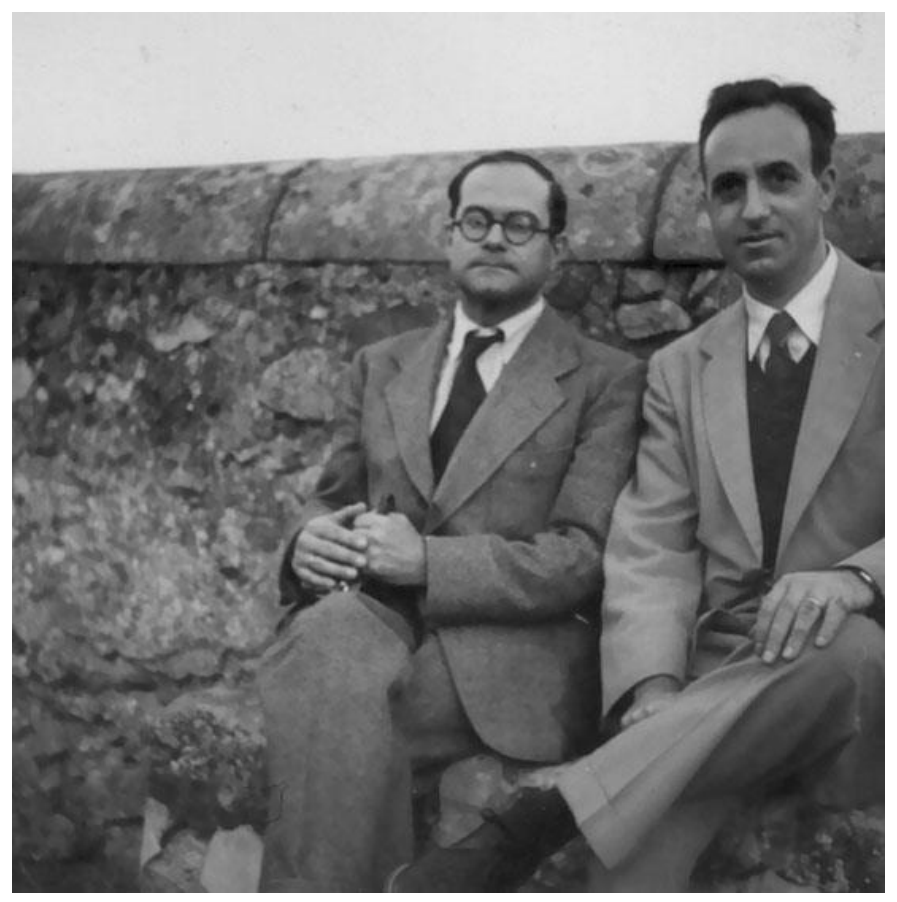

Ilustración 10: Fotografía de José Ferrater Mora con Julián Marías en Soria.

(Fuente: Fundación Biblioteca Virtual Miguel de Cervantes Tomado de: http://www.cervantesvirtual.com/portales/julian_marias/imagenes_amigos/)

De hecho, se tiene registro que a partir del año 1952, visitó prácticamente cada verano Barcelona, y aunque dedicaba la mayoría del tiempo al desarrollo de visitas familiares, se sabe que también desarrolló visitas profesionales, con autores y pensadores 
españoles que tampoco residían en Barcelona, como en el caso de José Luis López Aranguren o Julián Marías, entre otros letrados.

Empero, su conexión con España se verá opacada por sus compromisos en Norteamérica, lo que siempre acrecentaba la improbabilidad de su vuelta definitiva a la madre patria. Todo ello en parte porque José Ferrater Mora iría integrándose cada vez más con la realidad estadounidense, por un lado porque fortaleció su posición en el Bryn Mawr College, donde llegó a ocupar el cargo de Director del Departamento de Filosofía; y por el otro, dado los crecientes contactos con las bibliotecas norteamericanas, las cuales le permitían profundizar sus investigaciones, particularmente, aquellas relacionadas con la lógica formal, la filosofía del lenguaje y la tradición filosófica analítica y anglosajona.

No hay que dejar pasar el hecho de que su vida personal también dio un giro importante, tras la separación de su primera esposa y luego sus nupcias con Priscilla N. Cohn, quien se convirtió en su compañera vital hasta las ocaso de su vida.

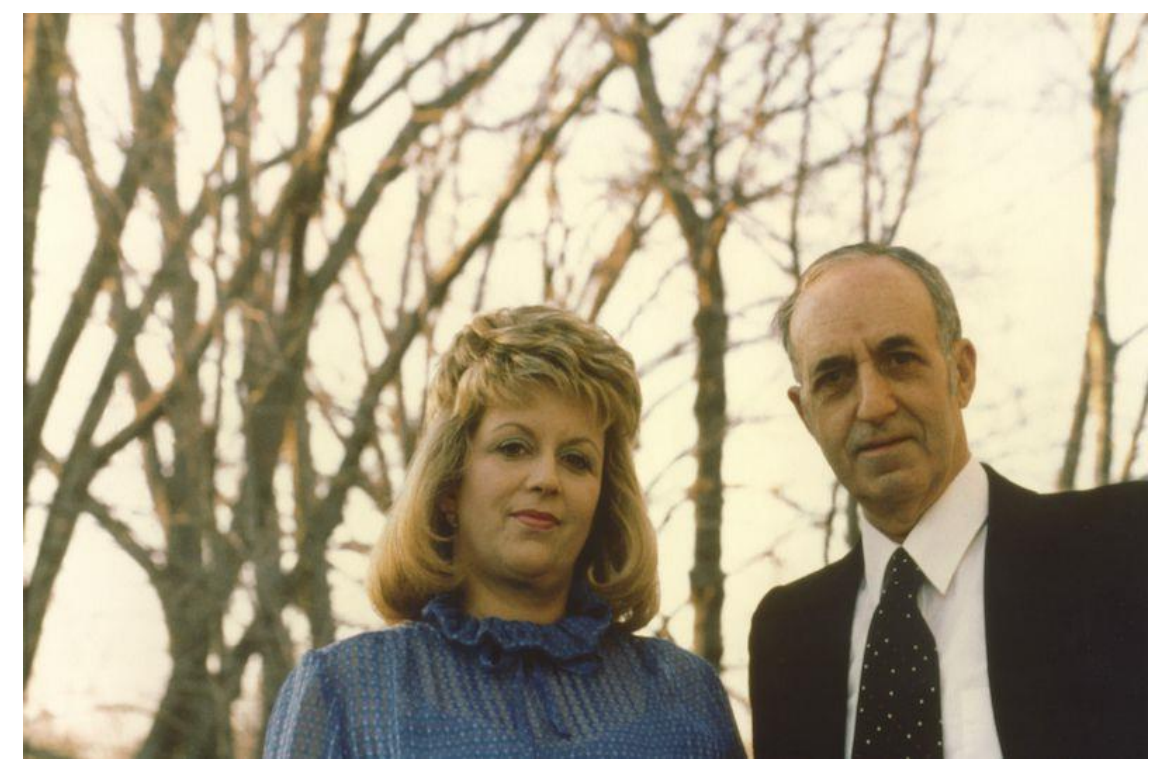

Ilustración 11: José Ferrater Mora y su esposa, Priscilla N. Cohn, (Fuente: http://www.catedraferratermora.cat. Tomado de: http://www.catedraferratermora.cat/catedra/historia/).

Toda esta realidad personal concibió que en el lapso de los años ochenta, sin importar que el proceso de democratización en España estaba del todo logrado, se aferrara José Ferrater Mora en la idea de mantenerse fuera de su madre patria, sin plantearse volver. Será precisamente durante esta década, cuando el intelectual catalán empiece a tener un considerable reconocimiento no únicamente en España sino fuera de sus fronteras. 
Será indudable que el "descubrimiento" de la obra y el pensamiento de José Ferrater Mora durante esa década, responda a su interés político, social, intelectual y académico por la realidad que se evidenciaba del exilio, con lo cual tendría que considerarse la recuperación de su obra conjuntamente a la de otros autores exiliados.

Con todo, existe una verdad evidente, y esta es que José Ferrater Mora de ningún modo dejó de estar presente en España, puesto que entre los años 1950 y hasta 1980 mantuvo en la península una constante presencia intelectual. Desde el año 1955 verán luz sus primeras obras publicadas en España, entre ellas la segunda edición de Les formes de la vida catalana, publicada en Barcelona por la Editorial Selecta y Cuestiones disputadas: ensayos de filosofía, que fuera publicado en Madrid por la Revista de Occidente.

A partir de ese año, aparecen en España múltiples escritos de José Ferrater Mora, entre otros, obras fundamentales para comprender su pensamiento, ajustados a su visión más estrictamente filosófica, como son: El ser y la muerte (1962), El ser y el sentido (1967), Cambio de marcha en filosofía (1974) y De la materia a la razón (1979).

No habrá que dejar de hacer mención a la importancia de la publicación que en el año 1967 hiciera de dos volúmenes de sus Obras selectas y, por supuesto, la aparición en el año 1979, por primera vez en España, de su ya muy afamado Diccionario de filosofía, el cual hallábase internacionalizado, su primigenia edición fue publicada en México en el año 1941.

A la larga lista de libros publicados en España, entre los años 1955 y 1980, habrá que incorporar también los numerosos artículos periodísticos que surgen, a partir del año 1970, en las páginas de periódicos como La Vanguardia Española y El País, por medio de los cuales José Ferrater Mora aspiraba evidentemente dirigirse a un público más amplio y menos especialista.

Es imposible dejar pasar además la creciente presencia de José Ferrater Mora en los medios de comunicación social, un ejemplo de tantos es la entrevista titulada Ferrater Mora: filósofo, irónico y cinéfilo que realizó la cadena RTVE en el año 1975 para la serie "Nuestros cerebros de fuera".

El éxito que algunas de las obras ya citadas obtuvieron en España, motivó que durante la época franquista, fueran empleados en la academia como manuales, tal es el caso de La filosofía en el mundo de hoy, la Lógica matemática o El ser y la muerte. 
La influencia que José Ferrater Mora alcanzó en los pensadores españoles contemporáneos, resulta impropia medirla únicamente sobre la base de sus escritos aparecidos en España durante su exilio, por el contrario deberán tenerse en consideración las relaciones personales que el pensador catalán mantuvo con algunos de estos autores.

Es por ello que se hace imprescindible recurrir a la indagación del epistolario de José Ferrater Mora, el cual es conservado en la Cátedra Ferrater Mora de la Universidad de Girona, donde se ofrece un valioso testimonio de las relaciones mantenidas por el filósofo con algunas de las personalidades más distinguidas del panorama filosófico en lengua hispana.

Como ya se ha dejado en evidencia, la obra intelectual de José Ferrater Mora se caracterizará por su amplitud y diversidad. El desarrollo de obras filosóficas y enciclopédicas, su incursión en la narrativa, el periodismo y la poesía. Su paso por el mundo de las traducciones, principalmente de lenguas como el francés, inglés y el alemán, dado su inagotable interés por los idiomas, adicional al hecho de que prácticamente no hubo tema humano que escapara a su ojo analizador, y no dejó de examinar los campos del saber y la cultura en general. Es conocido que José Ferrater Mora revisaba minuciosamente su propia obra, hecho que queda perceptible ante la acción de una constante reescritura. A ello se agrega la extensa bibliografía de artículos periodísticos, los cuales gozaron de profundidad académica.

La Cátedra Ferrater Mora de Pensamiento Contemporáneo, de la Facultad de Letras de la Universidad de Girona, ofrece un aporte minucioso de su obra, del cual se extrae a continuación la reseña de algunas de sus más importantes obras en orden cronológico:

Cóctel de verdad. Madrid: Literatura, año 1935.

Primer libro publicado, consta de diversos ensayos divulgados con anterioridad en varias revistas. Su contenido fue preconizado y José Ferrater Mora se encontró con elogios que vislumbraron su prometedora carrera como filósofo.

Diccionario de filosofía. México: Atlante, año 1941.

Génesis editorial de la obra que le dará el reconocimiento y prestigio en todas las escuelas de filosofía de Hispanoamérica y el resto del mundo. El desarrollo de conceptos, corrientes, autores y obras de filosofía son dignos de elogio por su rigurosa redacción y 
documentación. A lo largo de seis décadas ha sido revisado, actualizado en varias ediciones incluyendo sus respectivas reimpresiones.

Las formas de la vida catalana. Santiago de Chile: Agrupación Patriótica Catalana, año 1944.

Publicada primeramente en catalán en el mismo año, dicha obra constata que si bien encontrado en el exilio, José Ferrater Mora nunca dejó de pensar y de estar informado sobre su tierra. De esta obra comenta el investigador Santos López Alonso:

"Toda la obra de Ferrater respira un estilo profundamente catalán. No se trata del hecho simple de que haya nacido en Barcelona o publicado algunos libros en catalán, sino que las formas del ser catalán -continuidad, "seny», mesura, ironía- se dan en toda su producción. Su espíritu de trabajo, que se manifiesta en un constante rehacer de las obras ya terminadas, es otro de los rasgos característicos de su idiosincrasia catalana. Este hecho es tratado por él mismo en Las formas de la vida catalana." (1968: 759).

Unamuno: Bosquejo de una filosofía, Buenos Aires: Losada, año 1944.

El propio José Ferrater Mora, describe en su prefacio que este elaboración constituye un ejercicio de estudio interpretativo y no crítico o erudito, y es precisamente por lo que se llama bosquejo. Trinidad Aler Gay destaca lo siguiente:

"Ningún cabo queda suelto en su análisis interpretativo. Esta es, a mi entender, la mejor cualidad de la obra junto a la siempre estimada claridad expositiva: la impresión de que se ha intentado llegar fielmente a las entrañas de una filosofía." (1986: 242).

Cuatro visiones de la historia universal, Buenos Aires: Losada, año 1945.

Según algunos resúmenes presentados sobre este libro se hace mención que estas cuatro visiones de la historia universal pertenecen propiamente a las concepciones omnicomprensivas que estudian los desarrollos concretos como meros signos o símbolos del curso seguido por la humanidad. Este género, según señala el mismo José Ferrater Mora, puede parecer un tanto fantasioso, pero posee un elevado poder de sugestión. En rigor, y digan lo que digan sus autores, no se trata tanto de lo que la historia, en tanto historia universal, ha sido y es, como de lo que se supone que debe ser y que, por tal razón fundada en una esperanza, será. El volumen resume las concepciones de cuatro grandes pensadores y destaca el ideal moral que las anima: San Agustín, Vico, Voltaire y Hegel. 
La ironía, la muerte y la admiración, Santiago de Chile: Cruz del Sur, año 1946.

Esta obra es quizás la que hace una apertura a la tanatología ferrateriana, aunque antecedida por artículos publicados en revistas, es en La ironía, la muerte y la admiración cuando el filósofo barcelonés aborda la muerte con un sesgo existencial. Posteriormente se observa en José Ferrater Mora una reelaboración de su concepción sobre la muerte, pero sin distanciarse mucho de sus primeras emisiones sobre este tema. Con respecto a la ironía, mediante paráfrasis José Ferrater Mora especificó: "la ironía es más un método de la moral que un puro y estéril juego de la inteligencia, por lo que es válido afirmar que la ironía constituye en sí misma una moral" (Citado por Hernández, 2001: 153).

El sentido de la muerte, Buenos Aires: Sudamericana, año 1947

Es en este libro donde comienza a tomar forma el integracionismo como método del sistema filosófico de José Ferrater Mora. De su concepto de la muerte se extrae el siguiente fragmento:

"Una historia de las ideas acerca de la muerte supone, en nuestra opinión, un detallado análisis de las diversas concepciones del mundo -y no sólo de las filosofías- habidas en el curso del pensamiento humano. Además, supone un análisis de los problemas relativos al sentido de la vida y a la concepción de la inmortalidad, ya sea bajo la forma de su afirmación, o bien bajo el aspecto de su negación. En todos los casos, en efecto, resulta de ello una determinada idea de la muerte. Nos limitaremos aquí a señalar que una dilucidación suficientemente amplia del problema de la muerte supone un examen de todas las formas posibles de cesación aun en el caso de que, en último término, se considere como cesación en sentido auténtico solamente la muerte humana." (Ferrater Mora, 2004: 2472).

El ser y la muerte: Bosquejo de filosofía integracionista, Madrid: Aguilar, 1962

Indudablemente, el contenido de este libro es el que más caracteriza al escritor catalán. Constituyendo la sistematización de su propio método filosófico y proyectando su pensamiento con identidad única, pese a las amplias influencias y corrientes estudiadas de las que se confiesa tributario, como es el caso del pensamiento kantiano. José Ferrater Mora señala:

"Del subtítulo de esta obra se desprende que aspiro a desarrollar una posición llamada «integracionismo». Según la misma, no se admite ningún género de «absolutos». Los términos que suelen emplearse para nombrar cualesquiera pretendidos «absolutos»-«la materia», «la conciencia», «el sujeto», «el objeto», etc., se limitan a designar-y - casi sería preferible decir simplemente «a apuntar hacia»conceptos-límites. Estos conceptos denotarían realidades absolutas 
sólo en el caso de que las hubiese. Puesto que, en mi opinión, no las hay, ni es menester que las haya, los conceptos-límites correspondientes propiamente no denotan; permiten únicamente situar, ontológicamente hablando, las realidades efectivas. Estas se hallan entre los que llamaré a veces «polos»o "polaridades»" (1962).

A lo cual agregará en lo inmediato las precisiones respectivas:

"Desde este punto de vista, no hay nada que sea -o sea concebiblecomo "pura y simple materia», es decir, como absoluta y únicamente material, sin posibilidad de dar origen, mediante procesos emergentes, a otras formas de realidad. No hay tampoco nada que sea «puro y simple espíritu» $o$, en un lenguaje menos idealista, "pura y simple conciencia», enteramente desligados de sus bases materiales, $o$ físicas. Concomitantemente, no hay nada que sea «absolutamente objeto» o «absolutamente sujeto». Casi podría decirse que no hay tampoco nada que sea "puramente mecánico»o "puramente orgánico»-en los sentidos no siempre muy precisos que estos vocablos han tenido en los ya periclitados debates entre filósofos de la biología de propensiones respectivamente «mecanicistas» $y$ «organicistas». Es legítimo echar mano de predicados como 'es material', 'es consciente', 'es mecánico', 'es orgánico', etc., pero siempre que, desde el punto de vista ontológico, no se los haga funcionar como términos denotativos de supuestas entidades o realidades «absolutas»" (1962).

De la materia a la razón, Madrid: Alianza Editorial, S.A. año 1979.

Considerada una de sus obras filosóficas más importantes, entre otras cosas por la cantidad de temas que atraviesa, De la materia a la razón ofrece un amplio abordaje de las realidades profundas del ser.

Una de las particularidades que la caracteriza es que José Ferrater Mora se atreve a desvanecer los absolutismos, alejándose considerablemente del dogmatismo de la misma manera que lo hace del relativismo.

$\mathrm{Su}$ escritura es tan audaz que logra consolidar su sistema integracionista como un método donde la ciencia filosofal es expuesta con rigor argumental y dejándola abierta a debates posteriores, en la que sus conjeturas develan que no todo está escrito en la filosofía como en la vida misma. Bajo la premisa del autor, impresa en el prefacio que él mismo elabora: "Las cuestiones relativas al carácter de las acciones humanas, de los deberes y de las normas, especialmente las normas juzgadas morales, siguen siendo uno de los motores del proyecto realizado en el libro presente." (Ferrater Mora, 1979: 14). 
En su primer capítulo, titulado "Realidades", aborda asuntos descritos de forma amena, describiendo conceptualmente 'el mundo', pasando por "la posición realista", "monismo y pluralismo", otros temas socioculturales, lo orgánico, comunicación lingüística y lo neural-mental. Finaliza ese capítulo con los "ismos" de los cuales dice: "designan tendencias están desacreditados, porque cualquiera de ellos puede designar tan diversas orientaciones que, al final, nos sentimos perdidos. Suministrar otro nombre similar terminado en 'ismo' para despejar las dudas es casi siempre recomenzar la misma operación" (Ferrater Mora, 1979: 83).

Pero José Ferrater Mora, lejano al determinismo y a las tendencias absolutistas no procede a desdeñar los 'ismos' al afirmar: "sin embargo, estos 'ismos' no son totalmente inútiles. Pensándolo bien, resultan bastante beneficiosos, porque permiten saber por lo menos por dónde anda un filósofo y en este sentido son testimonio de su grado de honestidad intelectual" (Ferrater Mora, 1979: 83).

El resto del libro tiene en cuenta las "acciones" y los "acontecimientos", que para Ferrater Mora basta "una comprensión intuitiva del 'acontecimiento'", que de acuerdo a su criterio:

"Consideraré que en todo acontecimiento hay algún proceso. Pero en la medida en que hay en los procesos cambios de estados, pueden ser considerados asimismo como acontecimientos. Desde este punto de vista, todo lo que ha pasado, pasa o está pasando en el mundo puede ser visto como algún acontecimiento, más o menos simple o complejo, más o menos aislable de otros acontecimientos. Así, hay acontecimientos en todo los niveles de realidades, $y$ de comportamientos de realidades, [...] Puede hablarse, según ello, de acontecimientos físicos, orgánicos, sociales y culturales. Decir que hay acontecimientos en tales niveles no quiere decir que, sobrepuestas a las realidades y a los comportamientos de realidades, de referencia, haya una clase especial de realidades o de comportamientos de realidades que se llamen "acontecimientos». Los acontecimientos son cambios de estado de cosas y modificaciones de comportamientos." (Ferrater Mora, 1979: 88).

Siguiendo con el tema de las "acciones" y "acontecimientos", el filósofo sostiene que "esto no equivale a negar que las acciones sean asimismo acontecimientos, pero equivale a sostener que no todos los acontecimientos son acciones" (Ferrater Mora, 1979: 88).

En el mismo marco de análisis examina las "tareas", "máquinas", "interacciones", "deberes", la "moral" y "sentido", "valoraciones", "criterios", "vivir", "ser libre" y en la 
sección "El reino de este mundo" correspondiente al capítulo IV, hace referencia a la razón y la racionalidad desprendida de los dogmatismos:

"porque las condiciones mismas que se establecen para alcanzar un conocimiento adecuado y para comportarse adecuadamente son de carácter fuertemente crítico. El ejercicio de la racionalidad conlleva su propia corrección y, desde este punto de vista, representa una emancipación de todo dogma. " (Ferrater Mora, 1979: 188).

En la parte final de la obra, José Ferrater Mora despliega un apéndice al que nombra "Las cartas sobre la mesa", que no es un anexo a lo expuesto del cual prescindir, ya que describe desde una perspectiva metódica a ciertos modos de hacer filosofía, procurando además "mantener la filosofía depurada de metafilosofía como sea posible" (Ferrater Mora, 1979: 191). En esta sección destinada al apéndice, que especifica: "Cómo hacer filosofía", el autor catalán da una curiosa clave sobre la filosofía en sí misma:

"Cabe argüir asimismo que la filosofía no tiene por qué decir nada, ni menos «construir» nada, y por supuesto tratar de alcanzar ningún conocimiento de nada; que lo mejor, tal vez lo único, que se puede hacer es proceder a una «deconstrucción» y reconocer que la filosofía es un "género» de «escritura», que no es ni siquiera heterodoxo, extraño o anormal, porque no es representativo de nada, ni dice nada, incluyendo decir algo acerca el filósofo que produce tal escritura. La filosofía es entonces literalmente "palabras», que pueden ser palabras cruzadas, pero siempre que no se pretenda ni siquiera que los cuadros en blanco deban ser llenados siguiendo ciertas pautas." (Ferrater Mora, 1979: 195).

Concluyendo acerca de las consideraciones sobre esta obra, el propio filósofo barcelonés define su libro en la parte final del prefacio:

"Una de las conclusiones que se desprenden del libro es a la vez una de sus premisas. Esta es una situación nada infrecuente en exploraciones filosóficas. La conclusión-premisa aludida es: si es posible (aunque sólo como un ideal inasequible) la objetividad completa en el conocimiento, y si es posible (como un ideal del mismo género) la objetividad en la formulación de normas reputadas «morales» y en las valoraciones, todo ello es sólo en tanto que se trata de actividades y resultados de estás, que aspiran a ser racionales, y que son siempre naturales. No es menester introducir ningún otro mundo que el que va de la materia a la razón." (Ferrater Mora, 1979: 15).

Fiel a su denominador "integracionista", José Ferrater Mora bosqueja una vez más su método y sistema filosófico que lo distingue en la república del saber. 
La filosofía actual. Madrid: Alianza Editorial, S.A. 1969.

Esta obra describe de manera compendiosa las tendencias filosóficas más actuales o vivas y las corrientes más predominantes. Idealismo, personalismo, realismo, naturalismo, historicismo, pragmatismo, instrumentalismo y corrientes afines, intuicionismo, fenomenología, existencialismo, estructuralismo, positivismo lógico, filosofía analítica, neoescolastismo, marxismo.

Consiguientemente todos los temas tratados en este libro están desarrollados con amplitud en el Diccionario de filosofía, los artículos de esta obra tienen cierta tonalidad narrativa, manteniendo la rigurosidad argumental sin la suntuosidad enciclopédica y academicista. José Ferrater Mora reflexiona sobre la importancia y trascendencia de la filosofía en tiempos modernos, haciendo frente a los antifilósofos que afirman que la filosofía ha muerto.

Otros temas tratados son "La idea de la filosofía", "Los tres «imperios filosóficos", en los que se incluyen los 'rusos', el resto de los 'europeos' y los 'angloamericanos' enmarcados como 'las tres filosofías'.

El filósofo dedicará los últimos capítulos a la relación de la filosofía y la sociedad; entre sus temas se exponen: "La historia como filosofía y la filosofía como historia", "Rasgos de la sociedad contemporánea", "La filosofía de la sociedad contemporánea" y "La comunicación de la filosofía".

Una afirmación contundente realizada por José Ferrater Mora, que resalta por su sencillez, en relación a la comunicación en la filosofía expresa:

"Lo más deseable fuera que los filósofos pudieran hacer lo que
algunos artistas han conseguido a veces: producir obras capaces de
ser entendidas en niveles distintos, de suerte que muy diferentes clases
de humanos puedan seguir lo que se diga de acuerdo con sus propias
capacidades." (Ferrater Mora, 1969: 184).

Y eso es precisamente lo que intenta hacer La filosofía actual, hacer la filosofía accesible a todos sin banalizarla, ni dejar a un lado los grados de complejidad que caracteriza a la tarea filosófica que tiene sus respectivas técnicas y lenguajes.

Al margen de este aporte provisto por la Cátedra Ferrater Mora de la Universidad de Girona, se considera meritorio presentar una representación más esquemática, también 
recopilada por la mencionada cátedra y expuesta a los seguidores de José Ferrater Mora a través de su sitio electrónico oficial:

\section{Obras principales.}

El hombre en la encrucijada, Buenos Aires, Sudamericana, año 1952.

Cuatro visiones de la Historia Universal: San Agustín, Vico, Voltaire, Hegel, año 1955.

Reflexions sobre Catalunya, (en catalán) (Reflexiones sobre Cataluña), año 1955.

La filosofía en el mundo de hoy, Madrid, Revista de Occidente, año 1959.

Una mica de tot, (en catalán) Palma de Mallorca, Mallorca, Moit, año 1961.

El ser y la muerte: bosquejo de filosofía integracionista, Madrid, Aguilar, año 1962.

La filosofía en el món d'avui, (en catalán) (La filosofía en el mundo de hoy). Barcelona, año 1965.

Indagaciones sobre el lenguaje, año 1970.

Els mots $i$ els homes, (en catalán) (Las palabras y los hombres) año 1970.

El hombre y su medio y otros ensayos, Madrid, Siglo XXI, año 1971.

Las crisis humanas, Salvat, año 1972.

De la materia a la razón, Madrid, Alianza, año 1979.

Voltaire en Nueva York, año 1985.

Hecho en Corona, Madrid, Alianza, año 1986.

Ventana al mundo, Anthropos Editorial. año 1986.

El juego de la verdad, Barcelona, Destino, año 1988.

Joc de cartes. Epistolari 1948-1984, (en catalán), (Juego de cartas. Epistolario 1948-1984), año 1988.

Regreso del infierno, Barcelona, Destino, año 1989.

La señorita Goldie, Barcelona, Seix Barral, año 1991.

Mujeres al borde de la leyenda, Madrid, Círculo de Lectores, año 1991. 
En su obra póstuma es importante mencionar Mariposas y supercuerdas. Diccionario para nuestro tiempo, Barcelona: Península, año 1994, publicado gracias a Priscilla N. Cohn; y, Razón y verdad y otros ensayos, Editorial Renacimiento: año 2007.

De esta forma se deja por sentado la aportación que José Ferrater Mora proporcionó al mundo de las letras como parte de su legado.Por lo cual Ferrater Mora ha motivado el análisis de su vida y obra en múltiples investigadores, para mayores referencias. JosepMaría Terricabras en su ensayo "Estilo y pensamiento en la obra de Ferrater Mora" rescata palabras del especialista catalán en cuanto al punto desde el cual hay que partir para lograr caracterizar a un pensador:

"José Ferrater Mora solía decir que, para entender alguien, se debe tener en cuenta no sólo su situación histórica sino también su talante personal e, incluso, el papel que el azar ha jugado en su vida. Es por todos conocida la situación histórica de Ferrater [...] para entender adecuadamente tanto la concepción general de la filosofía defendida por Ferrater como su posicionamiento filosófico concreto durante tantos años se debe tener en cuenta su extraordinaria conciencia lingüística” (2014)

De esta forma Terricabras deja por sentada la lucidez de Ferrater Mora al manejar con pulcra claridad el hecho de que en filosofía será primordial la relación que se establece entre las ideas y la expresión que se hace de dichas ideas. Así sostiene:

"Está claro que Ferrater rechaza el dogmatismo con la misma contundencia que rechaza el relativismo. Por eso en filosofía hay que aceptar, según él, varios modos de expresión sin que ninguno de ellos pueda ser considerado la forma normal de expresarse filosóficamente, pero también sin que ello quiera decir que todas las formas son igualmente válidas ni, por tanto, que todas son válidas en cualquier caso. A Ferrater le resulta obvio que "toda filosofía es de alguna manera sistemática" aunque esto no quiere decir que tenga que ser". (2014b)

Josep-María Terricabras vendrá a considerar suficientemente plausible la hipótesis que sostiene que el estilo literario de un escritor será la fusión entre el estilo y el nivel filosófico propio del autor. Lo cual en Ferrater Mora viene además a amalgamarse con su tono reflexivo, lo que va en consonancia directa a la relación intima que surge entre la expresión y el contenido filosófico, considerando:

"Ferrater tiene un modo propio no sólo para buscar el interés y el sentido de las otras filosofías sino también para elaborar sus propias posiciones filosóficas. Por lo que hemos visto hasta 
ahora parece obvio que no podía aceptar un método que le llevara a la abstracción o el reduccionismo simplificador, sino que había de concebir una ayuda para comprender y expresar la apertura y complejidad de la realidad estudiada. Necesitaba un método que le permitiera defender, es decir, ejercitar, la precisión, claridad y transparencia que siempre reclamó. Este elemento esencial en su estilo filosófico es el método que se conoce con el nombre de integracionismo.". (2014c)

Precisamente, la publicación Teorema, en la ya mencionada entrevista hecha a José Ferrater Mora y que fuera publicada en 1972, a la obra ferrateriana se le reconoce como parte del plano integracionista, en el siguiente tenor:

"La copiosísima obra de Ferrater Mora, desde el Diccionario de filosofía a sus Indagaciones sobre el lenguaje, pasando por El ser y la muerte y El ser y el sentido, es un alarde de información, versatilidad y equilibrio. Una de las principales aportaciones de Ferrater es el «integracionismo» filosófico, fundado en la síntesis de contrarios, que primero se manifestó de una manera «ontológica» e histórica, y posteriormente ha cobrado un aspecto metodológico y crítico. Las obras ensayísticas, en varios idiomas (castellano, catalán, inglés), de Ferrater Mora son muy numerosas. Entre las últimas se cuentan Las palabras y los hombres y El hombre y su medio y otros ensayos." (Teorema, 1972: 97-108).

Sumamente esclarecedor resulta el artículo sobre José Ferrater Mora disponible en la Enciclopedia de obras de filosofía, autoría de Franco Volpi, del cual se presenta a continuación una transcripción analítica, la misma se empleará con la finalidad de capturar la visión aguda desarrollada por el intelectual apreciada desde las consideraciones expuestas por Franco Volpi y su equipo de especialistas:

“...Ferrater Mora, filósofo y ensayista, estudió filosofía en la universidad de Barcelona. En 1939 abandonó España tras la derrota del ejército republicano en la Guerra civil y, después de una estancia breve en Francia, vivió en el exilio en Cuba (1939-1941) y en Santiago de Chile (1941-1947). Gracias a una beca Guggenheim se trasladó a los EE UU, donde se estableció como docente del Bryan Mawr College a partir de 1949. Ferrater reescribía continuamente sus obras, de modo que cada edición supone a menudo una reelaboración de lo ya escrito..." (Volpi, 2005: 679)

De los aspectos biográficos expuestos con anterioridad pasará Franco Volpi acto seguido, a la observación de la obra de José Ferrater Mora, reconociendo en ella sus principales potencialidades y diferencias, que logran hacerla peculiar y atractiva para 
estudiosos y especialistas, cargada de una pluralidad de expresiones características de un gran autor:

“...Su obra es abundante y puede dividirse en creación filosófica, investigación sobre historia de la filosofía, periodismo y creación narrativa y cinematográfica. Los temas que dominan su pensamiento a lo largo de su vida son: 1935-1956, filosofía española escrita desde la tradición catalana y temas existenciales; 1957-1967, elaboración de pensamiento propio en el que la ontología es prioritaria; 19701974, filosofía del lenguaje y epistemología; 1975-1991, reelaboración de las categorías de su filosofía y dedicación a la ética. Su método y filosofía es el integracionismo o empirismo dialéctico; con él trata de construir un sistema abierto. El integracionismo se dirigió primero a resolver falsas disyuntivas dualistas entre doctrinas filosóficas y más adelante las que se dan entre conceptos..." (Volpi, 2005: 679).

En lo inmediato continuará incorporando detalles que hagan posible una cabal comprensión de la honda huella dejada por José Ferrater Mora tanto en la filosofía española como en la filosofía del restante de las nociones amantes de la sabiduría, presentado en una lista sus obras principales las cuales ya hemos abordado en esta investigación.

Para luego pasar al análisis de una de las principales obras presentadas por José Ferrater Mora, Volpi se detiene en interesantes aspectos sobre su formación -elaboración y reelaboración permanente- y demás balance de resultados:

“El ser y la muerte: bosquejo de una filosofía integracionista, la ed. Madrid 1962.

Esta obra tiene su origen en uno de los primeros libros de Ferrater, El sentido de la muerte (1947) y, como era habitual en él, fue reelaborada a lo largo de las sucesivas ediciones. Mientras en El sentido de la muerte el concepto central era el de muerte, ahora lo es el de ser, pues el problema de la muerte exige tratar las cuestiones acerca del ser, sentido, existencia, esencia, persona o valor. Por ello, hay que desarrollar una ontología del ser real subordinada a una ontología del ser mortal. Aunque el título de El ser y la muerte denota cierta influencia existencial, ésta no es decisiva en su contenido. En la ontología de Ferrater, ser real es igual a ser mortal, aunque mortal se entiende como cualquier modo de dejar de ser o de cesación..." (Volpi, 2005: 679).

Para José Ferrater Mora la filosofía es dinámica. Cuando él declara muerte no significa inacción, ya que la cesación no es equivalente a que ese organismo deje de vivir sino a una posible transformación, es por esta razón que la muerte da sentido a la vida, 
dado que si no existiese la muerte no habría existencia, demostrando de esta forma la dialéctica vida-muerta que caracteriza el método integracionista, también llamado empirismo dialéctico. Volpi agrega la característica dialéctica del integracionismo:

“...La muerte se dice de muchas maneras, con lo que en lugar de una analogía entis tendremos una analogía mortis. Muchas filosofías, a causa de tener una concepción de la realidad limitada, no han entendido que la muerte tiene un sentido amplio, a lo que Ferrater responde proponiendo un método -el integracionismo- que prescinde de entidades absolutas como «naturaleza», «espíritu», «objeto»o "conciencia», para dejar paso al uso de conceptos-límite opuestos pero complementarios. A cada modo de realidad le corresponde un modo de ser mortal y, aunque la muerte humana es la forma máxima de mortalidad, la noción de muerte no queda circunscrita a ella. Existe una gradación de mortalidad (de la mínima a la máxima: inorgánica, orgánica y humana) y la muerte es la propiedad que sitúa tipos de identidades dentro del continuo de la naturaleza..." (Volpi, 2005: 679).

Ante lo cual Franco Volpi sostiene que José Ferrater Mora saldrá al paso desdibujando las distancias a través de su método:

“... Aplicando aquí su integracionismo, Ferrater defiende la existencia de un continuo como el resultado de dos direcciones inversas pero complementarias: lo externo y lo íntimo. Estos son conceptos-límite a los que las cosas tienden, pero en sí mismos son absolutos inalcanzables. En lo inorgánico encontramos la máxima exterioridad, por lo que el morir de las cosas físicas es más bien una cesación o muerte mínima. En lo orgánico aumenta la intimidad y, con ella, la individualidad, de modo que morir es más propio cuanto mayor es la intimidad y la individualidad. En el hombre se alcanza en grado máximo la individualidad interiorizada y en él la muerte se da como algo propio y constitutivo de su ser, ya que alcanza lo más íntimo. La muerte pertenece al hombre antológicamente, porque en él llega a lo más interior y da sentido a toda su vida. En el hombre culmina la analogía mortis, pues en él se llega a la plenitud del hecho de morir. Aunque la muerte no da su ser a la vida humana, sí le da su ser en cuanto sentido, pues, en cuanto potencial, pasa a ser un factor decisivo de nuestra vida; la muerte carece de sentido, pero lo otorga a la vida..." (Volpi, 2005: 679).

Bajo la visión de Volpi, esta percepción motivará en Ferrater Mora una serie de interrogantes que darán luces en torno a la muerte y su relación indefectible con lo existencial:

“...Ferrater se pregunta si es posible la experiencia de la muerte del otro y afirma que sí, en cuanto inferencia vivencial indirecta. Así, la muerte humana no es sólo natural, también es social y hay que estudiar la muerte de los demás (moribundos y 
fallecidos) a la vez que la experiencia de los supervivientes. Así lo hace Ferrater, además de considerar testimonios literarios, con tres casos vividos por él mismo: muerte de un familiar anciano, de un combatiente desconocido en la guerra y visión de las víctimas de un bombardeo. Su análisis le lleva a concluir que la muerte (a) no tiene sentido si no la contemplamos desde el punto de vista de la vida y (b) justamente al eliminar la insignificancia ontológica de la persona otorga a ésta una dignidad que no habíamos advertido antes (Ferrater Mora 1947). A pesar de que morir es igual en todo hombre, también es cierto que morir es algo personal. No tenemos una experiencia pura de nuestra propia muerte, pero sí indirecta. La muerte absolutamente propia es más un límite hacia el que el hombre tiende que algo alcanzable. Ferrater finaliza estudiando la cuestión de la supervivencia y la inmortalidad a partir de distintas posiciones que se han dado a lo largo de la historia, sin llegar a una conclusión definitiva. Ahora bien, antes había dicho que, en cierto sentido, (a) nada es completamente inmortal ni nada es completamente mortal, y que (b) el hombre es el único ser capaz de soñar en ser inmortal (Ferrater Mora 1947)...” (Volpi, 2005: 679).

Todo ello decantará en el desarrollo literario de José Ferrater Mora y se dejará sentir con la fuerza que irá cobrando su pluma producto de la madurez que asumirá con el paso de los años. Entendiendo el dinamismo que caracterizará al método integracionista y que hace que el pensador catalán intervenga constantemente y reelabore su obra filosófica como lo expone Franco Volpi:

“...El método integracionista propuesto en El ser y la muerte y sus aplicaciones alcanzarán la madurez en obras posteriores. En El ser y el sentido se desarrolla la ontología integracionista anunciada en El ser y la muerte, pero la filosofía original de Ferrater culmina en De la materia a la razón, donde defiende un emergentismo de cuatro niveles (físico, orgánico, social y cultural) que emergen del anterior sin ser reducibles a él. Al leer El ser y la muerte, hay que tener en cuenta las variaciones introducidas por Ferrater a lo largo de sus ediciones. En principio fue escrita como primera parte de una tetralogía, de la que se publicó la segunda parte (El ser y el sentido), pero no las siguientes (El ser y el hacer y El ser y el deber ser). En su lugar publicó De la materia a la razón, con lo que el proyecto inicial devino trilogía. La edición de El ser y la muerte en 1979 está reelaborada desde el nuevo marco conceptual propuesto en De la materia a la razón, publicada en el mismo año. La traducción al inglés en 1965 ya había supuesto cambios notables respecto de la primera edición, cambios que también se introdujeron en la versión publicada dentro de las Obras selectas en 1967 (Ferrater informa detalladamente de estos cambios al final del segundo volumen de Obras selectas)." (Volpi, 2005: 679) 
Los distintos ángulos expuestos tanto por Josep-María Terricabras y Franco Volpi coinciden en destacar que filosofar para José Ferrater Mora significaba la aplicación de un método y constante revisión. Si bien es cierto que el pensador no se define bajo ninguna escuela o secta filosófica, está lejos de los dogmas y de los reduccionismos, su método filosófico incluye lo orgánico y lo inorgánico, si lo orgánico corresponde a la existencia, lo inorgánico tiene una connotación existencial. Por lo tanto es claro el razonamiento que estipula que si hay materia hay antimateria, ante ello Ferrater Mora de forma lúdica hace filosofía con el Ser y la muerte acercando visiones que pueden ser encontradas pero que a través del integracionismo le permiten tender puentes.

\section{José Ferrater Mora en la filosofía española.}

De José Ferrater Mora se ha conocido mucho tanto en España como en el exterior y así continuara en lo inmediato tal parece, ante cualquier tipo de adversidades, mediante su obra disponible en una cantidad de idiomas, lo que ha permitido su difusión y le parece prever cierta sostenibilidad de la que gozan escasos intelectuales en la actualidad.

Aunado a ello, la labor desarrollada por otros intelectuales, próximos a sus ideas como su compañera sentimental Priscilla N. Cohn; el investigador Josep-María Terricabras o más recientemente el profesor Carlos Nieto Blanco, han aportado sus contribuciones en esta difusión.

En relación propiamente a su visión del quehacer filosófico español, el intelectual aportó algunos detalles sobre el caso, recogidas por Antonio Márquez, quien en el año 1971 le hiciera una entrevista para el Diario de la Noche de Madrid durante una visita a Filadelfia. De ésta se recupera:

"Ferrater no conoce a la juventud española. El dice que no sabe a quiénes me refiero. El conoce a los que tienen treinta y treinta y tantos años. Nombra a unos cuantos: ¿Muguerza? ¿Trias? Otros cuantos nombres interesados en Lógica. He leído a Sacristán y está de acuerdo con él: con su librito rojo. No ha leído el de Gustavo Bueno todavía. No sabe que hubiera una polémica a propósito del libro de López Quintás, aunque sabe quién es este señor. Ferrater está tomando langosta y yo empiezo a enfadarme. La salida es obvia: ¿por qué hablar de Filosofía española en vez de hacer Filosofía? Pero resulta que seguimos hablando, cada vez más atropelladamente y en rampa, la rampa de los postres y el vino y el café, sobre Zubiri y marxismo, sobre las posibilidades de crear cátedras separadas o especializadas en las distintas filosofías de nuestro tiempo, sobre la 
necesidad de establecer la especialidad en todas las Universidades españolas. Ferrater no cree nada de esto conveniente o posible. Tampoco que cada disciplina deba terminar o comenzar con sus propios fundamentos filosóficos. ¿Filosofía del Derecho para abogados? ¿Filosofía de la Historia para historiadores? Aquí nos detenemos un poco más con nuevas referencias a nuestros "grandes" historiadores y la chistosa obra de Morente sobre asunto aledaño, o se ha creído." (Márquez, 1971: 14).
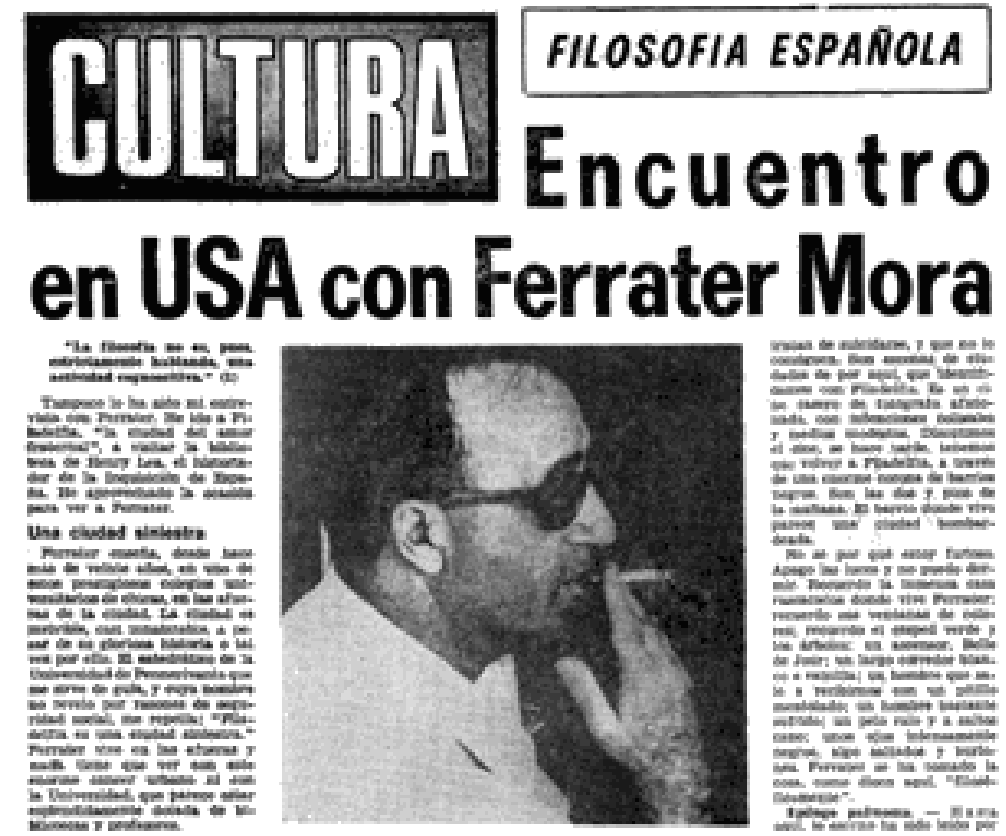

Ilustración 12: Reseña Entrevista a José Ferrater Mora por parte de Antonio Marquez

(Fuente: Márquez, A. (1971) Encuentro en USA con Ferrater Mora. Diario de la noche. Filosofía española. Madrid Año XXXIII, nº 10.356. Pág. 14.

Tomado de: http://www.filosofia.org/hem/dep/mad/9710825.htm).

En relación directa a este mismo tema y en el marco estructural de una entrevista posterior, específicamente durante el año 1985, Lola Díaz interroga a José Ferrater Mora, permitiendo conocer su visión acerca del quehacer filosófico de la España de esa época y el protagonismo de sus filósofos:

"LD: Parece que actualmente el mundo de la filosofía no cuenta con las grandes personalidades de antaño. ¿A qué cree que se debe?

JFM: Ahora hay menos personalismos y ya no existen nombres como Ortega o Unamuno, que, además de ser grandes personalidades, actuaban como tales. Es lo mismo que ocurre con la ciencia, donde existen hombres extraordinarios, pero anónimos. La filosofía, en este caso, vuelve a la solución del siglo XVII. En este siglo hay unos grandes filósofos, como Leibnitz y Locke, que no se sabía con exactitud si eran filósofos u hombres de ciencia, pero que establecieron las bases para la sociedad liberal de los siglos posteriores. Ahora ocurre lo mismo y el filósofo ha dejado de dar vueltas sobre sí mismo al modo escolástico para intentar dar soluciones sociales, éticas, políticas o científicas a los problemas del mundo de hoy.” (1985: 725). 
La realidad es que hablar de José Ferrater Mora en la filosofía española, es hablar de la historia de la filosofía española y viceversa. No obstante, aspirando hacer justicia al planteamiento inicial, así como persiguiendo la obtención de una precisión más exigente, se tomará en consideración al mayor número de elementos históricos, que constituyen esa vasta unificación multiforme, denominada en la actualidad filosofía española. Para ello se dará una mirada a la génesis de la creación de sapiencia en pro de tener una visión profunda acerca del hecho filosófico.

Méndez Bejarano en su obra Historia de la filosofía en España hasta el siglo XX (1928) deja una idea clara del camino a recorrer, para el alcance de una visión general y profunda acerca del tema, valdrá de guía direccional para el presente análisis.

Y es que la historia de la filosofía española, al igual que la universal, se ha desarrollado apegada a las diversas formas de tan polisémica palabra, es decir, en principio con una visión globalizadora que la describe como la "ciencia que trata de la esencia, propiedades, causas y efectos de las cosas" (Larousse, 2016), en segundo lugar como aquel "Conjunto de saberes que busca establecer, de manera racional, los principios más generales que organizan y orientan el conocimiento de la realidad, así como el sentido del obrar humano" (RAE, sf), en su visión más andragógica como "facultad dedicada en las universidades a la ampliación de estos conocimientos"(RAE, sf) y finalmente en una concepción más diversa como la "fortaleza o serenidad de ánimo para soportar las vicisitudes de la vida" (RAE, sf).

Muchos serán los textos que nos reseñen como fue desarrollándose el proceso filosófico en España, uno de los más destacados será el de José Luis Abellán que con su Historia Crítica del Pensamiento Español (1979) nos dará luces que favorecerán tal como lo indica su propio prólogo en pro de la maduración de nuestra personalidad colectiva como españoles será necesario el sentido de la cultura en sí misma. Por ello en los próximos párrafos nos adentraremos el devenir histórico para entender con mayor plenitud nuestra realidad actual.

En los llamados historiográficamente tiempos primitivos, es entendida España como un territorio que se civilizó por sus costas, o a partir de ellas; consecuencia de esto ya como país, primeramente adiestró el comercio y recibió cultura. A su geografía arribaron foráneos cautivados por el estímulo del intercambio de objetos poco valiosos frente a materiales preciosos, que obtenían en profusión. Pretendiendo disciplinar sus empresas 
establecieron almacenes y para su seguridad y salvaguardia, las fortificaron y guarnecieron con soldados. El lado norte de España se consiguió civilizar muchísimo más tardíamente, siendo conocido gracias al geógrafo griego Estrabón que existían en la plena barbarie tanto cántabros, gallegos como lusitanos.

En el área cultural, específicamente en la literatura desde Andalucía nacieron los poemas épico-mitológicos de Gerión y de Gárgoris, los épicos que entonaron la expedición andaluza a la ocupación de Córcega y Cerdeña, los ensayos sobre poesía trágica; la testimonial poesía cosmogónica, funeraria, epitalámica y gnómica. Con su propio abecedario fonográfico, Andalucía previa a la incursión fenicia, consigue contender la distinción de ser creadora de la escritura ante Egipto, Babilonia o China, a quienes se atribuye tradicionalmente tan memorable iniciativa.

Entre las prácticas religiosas resaltan el estudio de los carmina mágica, para evocación de espíritus y formulación de respuestas con los oráculos. Filóstrato, atestigua la fe en la vida futura y por ello los pueblos turdetanos celebraban sus exequias entre cánticos de victoria, revalidando su certeza en la vida eterna. La civilización andaluza es añejísima ya el historiador griego Asclepíades de Mirlea la adjetivaba tan pretérita y remota tanto, que la admitió ulterior en muy efímero periodo al trágico hecho proverbialmente conocido como diluvio universal.

Se abrió la puerta a la latinización. Con el aproximar de los legionarios a la república, el pueblo andaluz se sintió mucho más próximo con la ilustración romana que con la barbarie propia de la península. Al unísono del imperio la Bética no detuvo su progresividad. Contaba con urbes articuladas por anchurosas vías, ostentaba asimismo las únicas seis localidades libres que había en España, junto a un cálculo poblacional que se elevaba a varios millones de pobladores. Mientras tanto los turdetanos se instruían en el conocimiento y empleo tanto del latín de los invasores mientras aplaudían aparatosas presentaciones dramáticas, aunque en el lenguaje vencieran los mediterráneos, logrando el exitoso contagio de sus códigos y representaciones ${ }^{5}$.

\footnotetext{
${ }^{5}$ La época pagana ofreció una particularidad de las aetas argentea del florecimiento latino, dado que la mayoría de sus varones más brillantes fueron hispanos, y especialmente provenientes de Andalucía. Lucio Anneo Séneca (distinguido como Séneca el Joven), cordobés, hijo directo de Marco Anneo Séneca, (conocido además como: Séneca padre, Séneca el Orador, Séneca el Retórico o Séneca el Viejo) también cordobés, poseedor de una inteligencia cumbre durante este ciclo histórico-literario. Pese a una existencia accidentada, fue expatriado por Claudio y retornando transcurridos ocho años a Roma, a fin de educar a Domiciano, Agripina le designa como maestro para la formación de su hijo que entraba a la adultez; atesoró
} 
Séneca resulta admirable por la profundidad de sus reflexiones. Las propuestas filosóficas del recordado cordobés, como lo solemne de su verbo, arrojan el reflejo de su padecimiento, muestra valiosa del enorme pesar que incomodaba al resto de población consecuencia de los horrores imperiales. Lucio Anneo Séneca pretende una reducción de la filosofía al campo moral, la particularidad de su reflexión consiste en su voluntad de obtener el saber y a la perfección por sí mismo. El ser culto se torna superior a las deidades, las cuales son por naturaleza 'buenas', el ser culto se torna bueno. La revelación divina es la razón; entre los seres existe la filosofía, consistente en comprender las cosas, estas entre tantísimas otras ideas dieron a conocer a Séneca.

Paralelo temporalmente con Séneca, irrumpe con ímpetu Moderato de Cádiz (estudiado como filósofo hispanolatino, correspondiente al siglo I d.C.), quien disfrutaba de un prestigio muy fuerte en su momento. En su propuesta aspira acordar a Platón con Aristóteles; realizó ínfimos aportes al conocimiento, se dedicó a los pensadores clásicos, limitándose finalmente a fungir de pedagogo.

Tras concluir este ciclo se torna indudable la presencia de una producción de filosofía hispánica, y vale anexar que a lo largo y ancho del orbe no coexistió más filosofía que la de este sempiterno andaluz, puesto que ni epicúreos ni estoicos hallaron modo alguno para variar o superar a los anteriores maestros helénicos.

Luego llega la época cristiano-romana, cuando la península ibérica es evangelizada, prosperan las corrientes heterodoxas, aunque aún no exista alguna con representación nacional. Sobre el obispo hispano Prisciliano de Ávila y sus opiniones, muy poco se conocía y era fruto de lo comunicado por sus adversarios. Ciertos partidarios de Prisciliano facilitaban educación verbal, reservando ciertas doctrinas y llevando a cabo reuniones secretas con sus afiliados. Información que revela la causa de la discrepancia entre algunas aseveraciones hechas por Prisciliano.

Los priscilianistas, trasladaron a España los cadáveres de sus mártires, entre estos el de Prisciliano, les dedicaron culto; se organizaron sociedades ocultas, promoviendo una desmembración que sumergió a la Iglesia española en el desconcierto. Ascendió tanto el desconcierto, que los propios disidentes plantearon a San Ambrosio de Milán declinar sus acuerdos, si encontraba fórmula de avenencia. San Ambrosio se dirigió desde Milán a los tardíamente dona su hacienda al tirano y finalmente padece pena de muerte. 
obispos de España, sugiriéndoles tomasen en su comunión a los maniqueos y gnósticos cristianizados. En Toledo se reunió un concilio, donde los seguidores de Prisciliano declararon el abandono de los errores de su sociedad; no obstante permanecieron activos en sus textos y habilidades. El priscilianismo no sucumbió, pese a las adversidades. Aunque vanamente Honorio rompió hacia los priscilianistas, condenándoseles a la pérdida de sus patrimonios y de sus derechos civiles, declarando la libertad del ciervo que revelase a su patrono y asignando sanciones a los funcionarios estatales renuentes en atacar la herejía y demás formas de incredulidad.

Durante la edad media los más importantes sabios del paganismo dispusieron a la humanidad hacia el cristianismo, y en cuanto a la ciencia, igualmente como sobre la fe, coexiste, según reflexión de San Clemente, una comprensión superior, llamada gnosis, que contentiva de toda la verdad, es revelación del verbo, soberana percepción del principio omnipotente.

En seguida sucede la denominada época visigótica. Sin la presencia de San Isidoro de Sevilla, el ciclo histórico de los visigodos podría pasar desapercibido. Anterior al religioso no se reconoce en el ámbito de la reflexión, poco menos que entusiasmadas discusiones religiosas. La Iglesia fue fortificada contra la herejía por obra de San Isidoro, iniciador de la unidad de las legislaciones, consiguió estimular entre la nobleza visigoda la pasión por la ciencia, logró inclinar la monarquía ante la Iglesia, entre los clérigos optimizó sus prácticas, además se propuso y alcanzó a compendiar la ciencia de todo el continente europeo. Por último cabe destacar que los adeptos de Isidoro de Sevilla, prefirieron consagrarse fundamentalmente al estudio de temas vinculados a la fe o a la disciplina.

La intervención de los mahometanos en la cultura española se marcó entre los siglos XII y XIII, cuando los árabes españoles contribuyeron al Reino de Castilla con remembranzas helenas, observadas y asimiladas en Constantinopla, junto a otros aspectos formativos provenientes del oriente. Gracias a la toma de Alejandría se les permitió a los árabes entrar en relación con el pensamiento griego. Durante la etapa cumbre de las ideas islamitas, el dogmatismo se muestra con claridad.

Transcurriendo el imperio de Muhammad, surge por vez primera la filosofía entre árabes españoles. Durante las fechas fundacionales de este imperio, se produjo un altercado entre alfaquíes naturales de Córdoba y alimes, frente al instruido andaluz Abu Abd-alRahman Baky-ben-Machala, quien se había formado junto a los más afamados doctos 
orientales y se dedicaba a la enseñanza de las ideas de: Abi-Shuaiba y Abu-Bakr. El Soberano Muhammad dispuso que ambos bandos disputasen frente a él, declarando sobre Baky "no había que imposibilitar su cultura". Tanto el pensamiento musulmán como el hebreo se plantearon equivalentes problemáticas al pensamiento cristiano.

Los mozárabes se separaron de los hispanos, quienes se refugiaron entre las montañas norteñas, el resto de los pobladores quedaron sometidos por los invasores. Durante este ciclo es necesario diferenciar, por un extremo a los cristianos habitantes de estados musulmanes o mozárabes, del otro los musulmanes que vivían en tierra de cristianos o mudéjares.

La reflexión española gana espacios para su estudio, interviene en los intelectuales, amplificando sus raíces por todo el continente. Elevación en las doctrinas y capacidades de los filósofos, alcance de los sistemas y escuelas, aspecto distintivo y una sociedad atenta, permiten aseverar que no sólo se gozó de filósofos españoles, sino además, de una filosofía consumadamente española o al menos sumamente propia para aquella fracción de España que se correspondía hacia ella.

En los estados cristianos del norte, hasta el siglo XIV, a la categoría de muzárabes o apóstatas de la fe, tal los muladíes, identificados como los fieles cristianos que no quisieron doblar sus rodillas, no disfrutaron más enmienda que deponer el territorio conquistado por los musulmanes y acto seguido guarecerse en las serranías norteñas de la península.

La personificación en un individuo, es un rasgo de toda inclinación política o ideológica; el renacimiento en España, por ejemplo, personificó en la abrumadora estampa de Antonio de Nebrija. Nombre popular de Antonio Martínez de Cala y Xarana del Ojo, enciclopedista y polígrafo como el resto de genios del período, entre los padres del humanismo. Fue seguido por el obispo y cardenal Juan de Torquemada, de sabiduría más teológica que filosófica. Su objetante Alonso Tostado, tampoco labora una filosofía debidamente dicha, sino sus aplicaciones en cuestiones de filosofía moral, donde estudia virtudes teologales e inquiere cuál será la soberana entre las morales, concluyendo que es la prudencia; sin duda un fustigador de estoicos y senequistas.

Durante el siglo XVII, figuran los escolásticos. En Valladolid llegado el año de 1615, Pedro Hurtado de Mendoza, riguroso escolástico, da a conocer mediante publicación sus Disputationes a Summulis ad Metaphysicam. Junto a este y diferenciado por sus elevados 
conocimientos sobre filosofía, fue Fray Tomás de Ortiz, natural de Sevilla, fenecido en el año 1640 .

Juan Eusebio Nieremberg, de origen materno bávaro, resaltará como una figura representativa de ascetismo cuyo proceso creativo se alejará de la orientación del equilibrio tan expuesta por los principales teóricos del siglo XVI, muy especialmente por Fray Luis de Granada, quien pese a ser integrante de la orden ignaciana, no aparenta ser un ascético común, probablemente dado su linaje teutón, éste conservará en su norma anímica algo de idealista hecho que le mostrará más cercano a la decadencia mística.

Una de sus más importantes obras será: "De la hermosura de Dios y su amabilidad por las Infinitas Perfecciones del Ser Divino” de Juan Eusebio Nieremberg (Juan Sánchez, Madrid, 1641), breve tratado sobre moral cristiana, donde conjuga las enseñanzas de Aristóteles con las de Platón, utilizando además la prueba ontológica, expuesta por San Anselmo, obra que termina resultando incómoda a los ambientes escolares. Destacan además "Del aprecio y estima de la gracia divina, que nos mereció el Hijo de Dios, con su Preciosa Sangre, y Pasión” (Juan Sánchez, Madrid, 1638; Hospital Real y General, Zaragoza, 1640), “Obras y Días. Manual de Señores y Príncipes; en que se Propone con su Pureza y Rigor la Especulación y Ejecución Política, Económica y Particular de Todas las Virtudes” (Madrid, 1628), y “Centuria de Dictámenes prudente”s (Quiñones, Madrid, 1641), donde presenta un repertorio de aforismos, propios del paganismo, gran número de ellos inconexos.

Juan Eusebio Nieremberg es sistemático y por momentos despliega relativas perfecciones; empero falla en él, la nota particular, y, junto a ella la singularidad y el carácter. Preso de su desconocimiento y el de su época, en lo relacionado con las ciencias de la naturaleza, sea en su "Curiosa filosofía y cuestiones naturales" (Imprenta del Reino, Madrid, 1630), como en "Oculta Filosofía” (Barcelona, 1645), da cabida a inelegantes supersticiones, abusando de lugares comunes y careciendo del buen gusto de saber desechar desatinados juegos discursivos.

La degeneración de la mística. A manera de periodo de decadencia, el siglo XVII, poco construye, y escasamente sustenta los procedimientos heredados por la edad de oro, restringiéndose a desenterrar las más recientes derivaciones de sus predecesores, siendo de este modo como la Escolástica en decadencia encuentra su cuasi póstuma representación, mediante las exageraciones de un «ente dilucidado», de modo tal que la mística desciende 
desde las cúspides, donde fue cuidadosamente colocada por los grandes místicos áureos, hasta ubicarse en la delicada doctrina llamada quietismo, regeneración del nirvana y evidente exposición de su proveniencia oriental.

Se destacaron algunos escritores en la época, entre ellos figuran: El obispo Juan de Palafox y Mendoza, quien pese a ser hostigado por grupos jesuitas, expuso desde sus escritos los accesos de la vida espiritual; a él se unió Sor María de Jesús de Ágreda, con su obra Mística Ciudad de Dios (1670), que fue mucho más sesgada hacía la iluminación que al ascetismo; también Constanza Ossorio con su escrito Huerto del celestial esposo (Sevilla, de publicación posterior a su muerte en 1686), y Sor Gregoria Parra, dentro del claustro Gregoria Francisca de Santa Teresa, "según Menéndez y Pelayo, la más insigne poetisa mística de España" (Montoto, S., 1991:127), todos ellos revelan la decrepitud del pensamiento cristiano neoplatónico que llenó el siglo XVI de momentos gloriosos.

En el siglo XIX, el denominado positivismo comtiano se transmitió anteriormente que en la península los españoles radicados en Francia. Siendo el más dogmático entre sus representantes D. José Segundo Flórez, nace en 1789 en San Miguel de la Torre, fraile exclaustrado, educador en ciertos seminarios, reportero morador de París y compañero del apóstol. No tengo datos de que divulgara más que obras históricas, nada de filosofía y unas ¡Lecciones de Religión y moral! (1863).

Otra importante figura del positivismo fue el jurista catalán D. Pedro Estasén y Cortada, entendido en asuntos comerciales y económicos. Sus tertulias pro positivistas, expresadas desde el Ateneo de Barcelona, preocuparon a algunos elementos, provocando cierta desmembración de la Colectividad, seguido del establecimiento del Ateneo libre. Acopió sus conferencias en el volumen El positivismo o sistema de las ciencias experimentales (1877). Es de distinguir que el positivismo catalán ha permanecido continuamente más próximo con Auguste Comte y Émile Littré que con Herbert Spencer.

La teosofía tanto el espiritismo, descienden por similar metodología de la observación y la experiencia; lugar en que el espiritismo se distancia, puesto que la expectación confunde mucho menos que la experiencia u observación estimulada. En lo fundamental se advierten considerables y cardinales casualidades, únicamente que la teosofía exterioriza un cuerpo dotado de mayor complejidad. El ser humano se encuentra integrado, según el espiritismo, de tres apartados: espíritu, materia y periespíritu o 
mediador plástico. La escuela ocultista asigna a dichos apartados las designaciones de 'cuerpo material, alma y cuerpo astral' que, en realidad, corresponde a la imaginación.

Sobre la teosofía, solamente destacaremos que el crítico Eduardo Gómez de Baquero 'Andrenio', expuso una conferencia denominada El nuevo budismo, impresa en el año 1889. La bibliografía teosófica no fue muy fecunda en España durante el pasado siglo. Sus divulgaciones se sujetaron a transcripciones de obras foráneas. Se señalaron heterogéneos matices en la teosofía hispánica y sus partidarios, como Arturo Sardá y Antonio Ballesteros, quienes se conservaron en perfecta independencia. Durante el año 1919 se instaura en la calle de las Sierpes un Centro de saberes teosóficos de rasgos propagandistas, desde cuyo escenario se dirigieron un total de diez conferencias. Tras verse interrumpida su publicación la Revista Teosófica sevillana, rehabilitó su circulación en el mes de enero del año 1922. En Málaga se desconoció públicamente la teosofía hasta llegado el año 1925, fecha en que se constituyó el grupo Matreya, encabezado por José Palma. Similar situación ocurriría en Almería hasta el 28 de Marzo del año 1926, fecha de instauración del grupo Morya, por Miguel Gabín, careció de noticias sobre la reciente disciplina, para cuya difusión la dotaba de propicias circunstancias su colocación oriental y el hábito de sus acostumbradas vinculaciones con el continente africano transcurrida la Edad Media, generándose el curioso caso en su folklore de que archive tradiciones y costumbres de oriente, como la de pesar con oro los enfermos, entre otras, acumuladas varias por Federico de Castro.

Llegado el siglo veinte, el pensamiento filosófico ibérico ha alcanzado incuestionables adelantamientos y establecido un importante número de adeptos. En muchas universidades españolas, incluidas algunas del mundo, se presta singular atención a este saber filosófico; mediante su investigación permanente, tanto por el estudio y difusión del pensamiento español, sumado a la proyección internacional existente en obras y autores españoles, ya considerados clásicos en la bibliografía filosófica hispanoparlante.

Es importante recordar a Miguel de Unamuno, por aportar una de las contribuciones más significativas en la filosofía española y que además es referente indefectible de José Ferrater Mora, quien le dedicó uno de sus libros, del cual se hace referencia en la sección de este trabajo correspondiente a la introducción al existencialismo y ampliamente reseñado en páginas anteriores. 
Entre las casi tres décadas comprendidas entre los años 1916 y 1942, en España se dio la instauración de una sección de pedagogía, en la Facultad de Filosofía y Letras de la Universidad Complutense de Madrid, gracias al apoyo y gestión de Manuel García Morente. La Universidad Complutense ha sido pionera y alentadora, desempeñando el rol más decisivo en la consolidación de esta disciplina en España, además durante el curso de los años 1934 hasta 1935, incluyó entre sus planes académicos un par de materias de filosofía, aunque en años posteriores la llegada de la Guerra Civil española truncaría estas y otras tantas posibilidades de aprendizaje.

En este tiempo publicó José Ortega y Gasset, algunos de sus importantes trabajos de contenido filosófico educativo; razonando dicho proceso, tal un proyecto de la razón vital.

A cada ciclo histórico corresponden actos de mayor y menor significancia. La filosofía española es deudora de los aportes permanentes realizados por el filósofo barcelonés José Ferrater Mora, y exactamente también resulta válido el efecto inverso de esta afirmación, entendido como que el pensador catalán es deudor de la tradición filosófica hispánica.

La rectilínea historia permanece intacta en su habitual contemplación de sucesos, progresos, variaciones y otras pequeñas diferencias, recabadas con uniformidad para conservar un discurso coherentemente hilvanado, diseñado para soportar la inclemencia del tiempo; entre tantas variaciones, las aportaciones ferraterianas al día de hoy, parecen aptas para la larga intemperie.

Debe reconocerse que los sistemas de pensamiento de vanguardia como el integracionismo, siempre son tributarios de los sistemas o filosofías que le anteceden, aunque en esta breve historia de la filosofía española se excluyen muchos exponentes que por razones de espacio, tiempo y pertinencia con respecto al tema de este trabajo han sido obviados, pero de algún modo incluidos en determinados momentos a lo largo de esta tesis y sobre todo en relación a las influencias de José Ferrater Mora que se observan a lo largo de los contenidos dispuestos.

Con regularidad la historia de la filosofía aparenta sostenerse bajo un ritmo de desarrollo cíclico. De algún aspecto se adelanta, repitiendo bajo diferentes enfoques temas o problemas ya trabajados, en esencia los problemas eternos de la historia del hombre. Sin embargo aunque muy similar, se sabe no es el mismo rio, en su corriente se aleja el 
presente; tan solo algunos observadores, los más atentos, sabrán sacar de sus aguas lecciones para el porvenir.

Julián Marías, mediante su volumen "Historia de la Filosofía" (1998), se permite expresar con admirable claridad, sus puntuales impresiones acerca de José Ferrater Mora tanto como desde la óptica personal (atendiendo cada una de las facetas desarrolladas por el intelectual), como por su obra filosófica en general. Especificando los siguientes tópicos:

"José Ferrater Mora solo en un sentido indirecto pertenece a la «Escuela de Madrid». Nació en Barcelona en 1912; fue discípulo directo de los maestros de esta Universidad, sobre todo de Joaquín Xirau; se expatrió en 1939, residió en Cuba, Chile y finalmente en los Estados Unidos, donde es profesor en Bryn Mawr College" (Marías, 1998: 454).

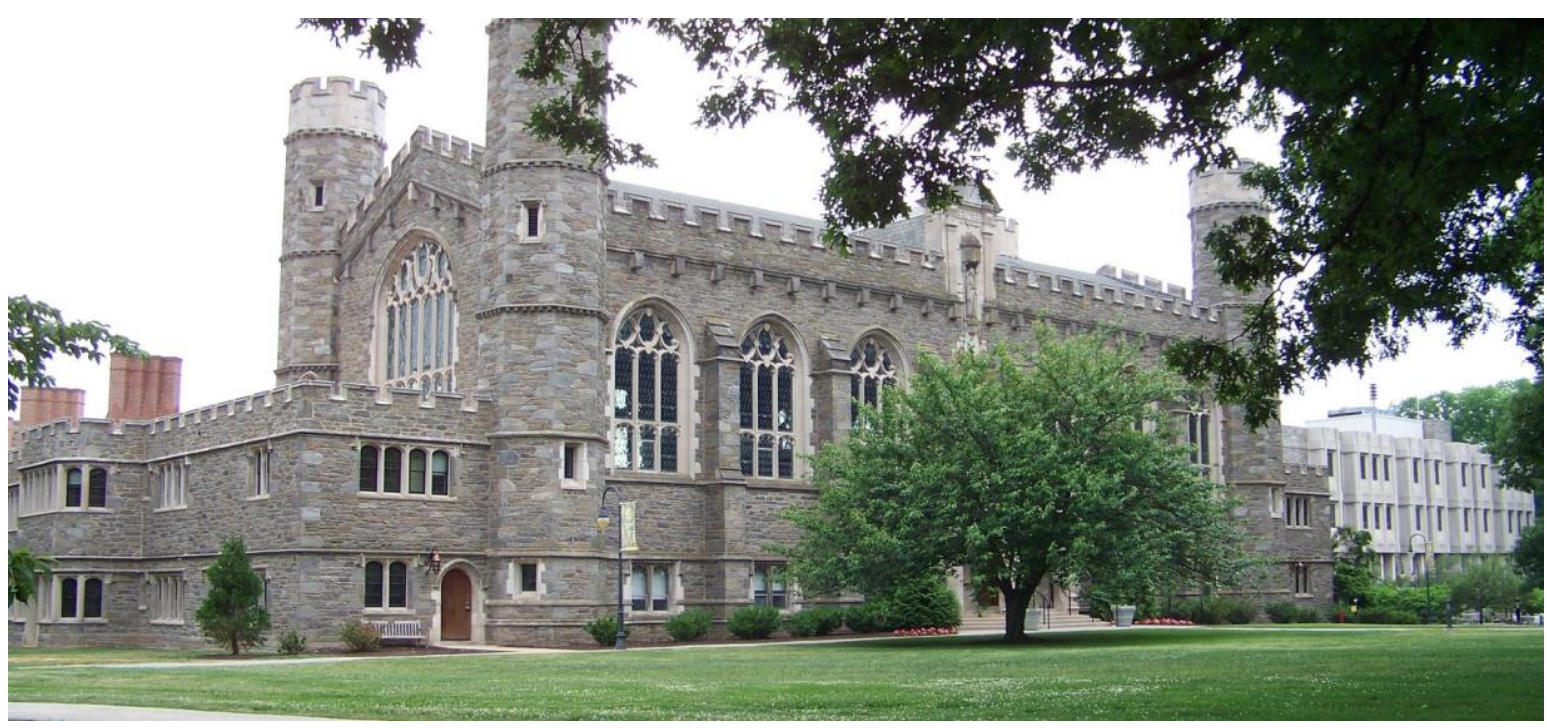

Ilustración 13: Fachada del Bryn Mawr College (ubicado en Pensilvania,

Estados Unidos de América); alma mater donde José Ferrater Mora cumplió con la mayor parte de su etapa como docente universitario, ocupando distintos cargos de importancia.

(Tomado de: https://www.brynmawr.edu/gsas/admissions)

Es Julián Marías al igual que José Ferrater Mora un apasionado por la filosofía y su historia. Continuando su repertorio de detalles, para ofrecer la figura de José Ferrater Mora, sostiene: "Pero sus relaciones filosóficas con dicha escuela son muy estrechas" (Marías, 1998: 454), en relación a la recién expuesta situación, adicionando: "Xirau era discípulo de Ortega; Ferrater, en 1935, al referirse a este, hablaba de «la actitud filial de quien ha bebido en él más que ideas, estilo; más que pensamientos, maneras»" (Marías, 1998: 454); importantes influencias a las que es menester agregar "la influencia de Morente y Zubiri ha sido sobre él también considerable; y no puede la que han ejercido Unamuno y Eugenio d'Ors" (Marías, 1998: 454). 
Hace mención Julián Marías de una de las principales obras de referencia en el campo de la filosofía española, reconociendo la vastedad como elemento característico del trabajo intelectual llevado a cabo por José Ferrater Mora a lo largo de varias décadas, destacando de su análisis que:

“...La obra de Ferrater es muy amplia. Lo más importante de ella es su Diccionario de Filosofía, que ha ido creciendo y perfeccionándose en sucesivas ediciones, hasta convertirse en un espléndido repertorio de información filosófica, a la altura del tiempo, equilibrado, riguroso y que significa una presentación personal y estrictamente filosófica de la realidad de la filosofía pretérita y actual..." (Marías, 1998: 454).

Es el año de 1941, el momento preciso cuando uno de los principales pensadores españoles del siglo veinte, reconoce a un número suficiente de elementos de diferenciación, que resaltan la relevancia de un peculiar pensador y de una obra filosófica de peso, que muestra como capital al Diccionario de filosofía, cuenta con suficiente bibliografía de gran valor. Julián Marías prosigue:

“...Otros libros de Ferrater son: Cuatro visiones de la historia universal, Unamuno: bosquejo de una filosofía, Ortega y Gasset: etapas de una filosofía, Variaciones sobre el espíritu, Cuestiones disputadas, La filosofía en el mundo de hoy, Lógica matemática (en colaboración con H. Leblanc), El hombre en la encrucijada y El ser y la muerte. Este libro es el que Ferrater considera más representativo de su pensamiento; es -siguiendo una práctica característica de su autor, que gusta de volver sobre sus escritos y rehacerlos- una versión nueva de su libro anterior El sentido de la muerte; lleva como subtítulo "Bosquejo de una filosofía integracionista»." (Marías, 1998: 454).

Un importante aporte al pensamiento español contemporáneo, es el otorgado por José Ferrater Mora al intentar, la creación y concreción de un método o de una corriente filosófica propia, Julián Marías aclara sobre dicha noción que:

“...Por «integracionismo» entiende Ferrater «un tipo de filosofía que se propone tender un puente sobre el abismo con demasiada frecuencia abierto entre el pensamiento que toma como eje la existencia humana o realidades descritas por analogía con ella, y el pensamiento que toma como eje la Naturaleza». No quiere una mera «nivelación» de las doctrinas, ni una selección ecléctica de elementos de ellas, ni un «compromiso» entre sus extremos; sino un puente por el cual hay que transitar en ambas direcciones, conservándolas en su respectiva insostenibilidad. Ferrater, con la mirada atenta a cuanto hace hoy la filosofía, tanto en Europa como en el mundo anglosajón e incluso en el soviético, presenta ese conjunto en una perspectiva relativamente plana, poco escorzada y que no es primariamente la suya personal. Una actitud análoga, fuera de la filosofía, aparece en 
su interesante libro Cataluña, España, Europa, escrito con la serenidad, agudeza e ironía inteligente que caracterizan tosa su obra intelectual...." (Marías, 1998: 454-455).

Entre las páginas rubricadas por José Ferrater Mora, bajo el titulado Diccionario de filosofía, se encuentra un artículo denominado "Filosofía americana", en el que se ubican las principales consideraciones ferraterianas sobre la llamada filosofía española. Afirmaciones que dejan entrever, qué, quién o quiénes configuran tal panorama, entendido como entramado de elementos indispensables, situación advertida por el angosto número de elementos involucrados por el autor catalán: José Ferrater Mora en el Diccionario de filosofía. Es ese sentido se han transcrito algunos párrafos contentivos de referido texto de reconocimiento:

\section{"FILOSOFÍA AMERICANA}

Cuando se coloca un adjetivo geográfico, nacional o plurinacional después de 'filosofía' pueden entenderse dos cosas. Una es que se trata de la filosofía producida en tal ámbito geográfico, en tal nación o en tal grupo de naciones. Otra es que, además de ser producida en un ámbito geográfico, en una nación o en un grupo de naciones, la filosofía de que se habla tiene ciertas características que la distinguen de la producida en otros lugares o por otras comunidades...." (Ferrater Mora, 2004: 1284).

Otras consideraciones puestas en análisis por José Ferrater Mora serían el uso del adjetivo más apropiado que facilite el desarrollo fluido del contenido, sorteando identificaciones erróneas que con su ineficacia pudieran desarrollar procesos de involución sobre la sana línea evolutiva, prediseñada por el intelectual barcelonés. Añadiendo que en cada caso, ya:

"No es fácil determinar que se entiende por 'filosofia' adjetivada del modo antedicho, porque no se entiende en cada caso lo mismo. Pueden compararse en este respecto las expresiones 'filosofia griega', 'filosofia oriental', 'filosofia india', 'filosofia china', 'filosofia árabe' 'filosofía europea (continental)', 'filosofía inglesa', 'filosofia alemana', 'filosofia rusa', etc. En la mayor parte de los casos se posee una idea relativamente clara de lo que se entiende por cada una de estas expresiones, pero aun así caben disputas. En lo que respecta a las llamadas «filosofías nacionales», por ejemplo, algunos estiman que las hay efectivamente (esto es que hay, por ejemplo, una filosofía italiana con características propias, distinta de la filosofía rusa, asimismo con características propias). Otros, en cambio, subrayan el carácter «universal» de la filosofía, o admiten, a lo sumo, una división entre «oriental» $y$ «occidental»" (Ferrater Mora, 2004: 1284). 
La presencia de rasgos frecuentes, propios de una genética común, serán algunos de los principales elementos que permiten a José Ferrater Mora advertir encontrarse justo frente a ciertas correspondencias entre el pensamiento hispanoamericano, tanto el elaborado en el suelo europeo como el emprendido sobre territorio americano; relación existente por encima de barreras idiomáticas o de diversos tipos. Expresando sus conclusiones en el siguiente orden:

"Históricamente se observan, en América Latina o Iberoamérica, ya a partir del siglo XVI, movimientos filosóficos muy semejantes en varios países (en gran parte, por similaridad de influencias, pero también por similaridad de condiciones históricas, políticas y sociales). Por ejemplo, y para limitarnos de momento a movimientos a partir del siglo XIX, se observa una generación adscrita al eclecticismo, a la cual siguió otra que abrazó el positivismo, sucedida por otra que s inclinó hacia una especie de «idealismo de la libertad»." (Ferrater Mora, 2004: 1285).

Del mismo modo el autor de El ser y la muerte, apunta sobre la constitución de tal grupo de textos e ideas, que entre las tendencias presentes hasta la fecha, prácticamente todas tienen cabida en tal inventario, situación que no representa limitaciones, por el contrario enriquece en diverso modo a cada una de ellas:

"Prácticamente todas las tendencias contemporáneas -con sus diversos matices-, así como todas las disciplinas, están representadas: así, por ejemplo, el existencialismo (Uranga), neokantismo (Larroyo), neoescolasticismo (Sepich), filosofía de la ciencia (Bunge), fenomenología (F. Miró Quesada C.), actualismo (Barboza), etc. lo cual no significa que los filósofos iberoamericanos se limiten a reproducir las tendencias contemporáneas, especialmente europeas. Muchos modifican considerablemente las tesis de sus filosofías preferidas atendiendo a los problemas que suscita la tradición autóctona; otros acogen varias tendencias para explicarse mejor la historia e las ideas filosóficas en su propio país y en Iberoamérica en general; otros intentan elaborar los tema filosóficos de un modo «universal» aun sin desinteresarse de lo iberoamericano, por lo menos desde un punto de vista históricofilosófico. Para que el cuadro fuera completo, no podría prescindirse, por otro lado, de influencias más directas ejercida sobre todo por pensadores españoles que han estado en Iberoamérica, ya de un modo ocasional (como Ortega, Ors y Marías) o de un modo más permanente (como José Gaos, J. D. García Bacca, E. Nicol, J. Xirau, María Zambrano, D. Casanovas, Manuel Granel, Antonio Rodríguez. Huéscar, Adolfo Sánchez Vásquez, Luis Abad Carretero, etc.). Por lo demás, una historia una historia completa de la filosofía iberoamericana no podría prescindir enteramente de su literatura y aun de su acción educativa. La «disolución» de la filosofía en la literatura y el pensamiento general ha sido una e sus características. Hoy lo es menos, porque la filosofía es cultivada en Iberoamérica no 
sólo en relación con la literatura, sino también con las ciencias naturales y sociales. Se cultiva asimismo el tipo de pensar analítico y el estudio de la historia de la filosofía” (Ferrater Mora, 2004: 1286).

El autor del Diccionario de filosofía en la antedicha entrada, titulada "Filosofía americana", elabora una muy breve selección donde reconoce a través de un par de muestras antológicas, lo que a su juicio y hasta el momento de redacción de tales investigaciones, representaban las selecciones más apropiadas sobre los autores u obras de mayor relevancia dentro de la denominada filosofía española. Estas son las siguientes:

"Antologías del pensamiento en lengua española: Antología del pensamiento de lengua española en la edad contemporánea, 1946 [incluye pensamiento español e hispanoamericano]. - J. L. Abellán y A. Monclús, coords., El pensamiento español contemporáneo y la idea de América, 2 vols., 1989 (I, El pensamiento en España desde 1939; II, El pensamiento en el exilio)". (Ferrater Mora, 2004: 1290-1291).

Es menester incorporar a esta retrospectiva contextual las palabras difundidas al respecto por la Revista Anthropos, edición número 49, donde se afirma:

"La condición de exiliado como consecuencia de la guerra civil la comparte Ferrater Mora, no sólo con un extraordinario -en cantidad y calidad- número de españoles relacionados con el mundo de la cultura en todas sus manifestaciones, sino que, por lo que a nosotros nos interesa, con los filósofos españoles de su generación que, salvo contadísimas excepciones, se vieron abocados a tomar el mismo camino." (1985: 29).

El hecho es que José Ferrater Mora viene a formar parte de un grupo de pensadores que despertó al desarrollo filosófico y se ganó el interés colectivo dentro y fuera de España. En la publicación de Teorema se rescata su pensar al respecto:

"T.: El pensamiento de los hombres de tu generación que han hecho filosofía fuera de España es hoy entre nosotros, y cada día más, objeto de interés y de análisis crítico. ¿Hay un denominador común a este pensamiento? ¿Qué justificación tiene para ti este fenómeno?

F.: El único denominador común a ese pensamiento español fuera de España es -y ya es bastante- el haberse desarrollado independientemente de las circunstancias político-sociales que han interferido en el pensamiento en España en los últimos treinta y pico de años. Creo que esto es lo que ha suscitado el mencionado interés" (Teorema, 1972: 97-108).

Obviar la impronta dejada en la sociedad española por semejante conflicto, distorsionaría cualquier óptica sobre tal panorama tanto por alejada como por ilusa, 
mientras que la consideración de dicho entramado conllevará a una mayor precisión ante las valoraciones con su obvia adhesión de variables de tipo objetivas o subjetivas. 


\section{CAPÍTULO 2: LA FILOSOFÍA COMO ONTOLOGÍA.}

Probablemente sólo a comienzos del siglo XVII cobra solidez el término ontología, aunque es conocido su origen mediante las palabras de Aristóteles, cuando razonó sobre una 'filosofía primera' en su tratado Metafísica (980), considerándola como la "ciencia del ser en sí", la cual se alzará como un tema dominante en el pensamiento existencial e integracionista de José Ferrater Mora, a partir del año 1957, cuando contaba con cuarenta y cinco años de edad y durante toda la década próxima siguiente.

El filósofo se concentra en la confección de un proyecto filosófico propio, donde la ontología se alza como el campo de acción principal. Desde su creación denominada integracionismo, lo ontológico se dirige y erige, específicamente con la publicación de $E l$ ser y el sentido (1968), aunque este interés ya había sido anticipado mediante el libro El ser y la muerte (1962); no se deberá soslayar las sendas elaboraciones académicas desplegadas a lo largo y ancho de su obra, tal es el caso de las entradas o artículos plasmados -de aparición y paulatina expansión- en su difundido Diccionario de filosofía, donde convergen términos como "Ontología"; "Prueba ontológica"; "Ontologismo"; "Ontosofía"; "Onto-Teo-Logía"; entre tantos otros donde la mayoría de estos escritos se encuentran caracterizados por un elevado rigor metodológico, de precisión investigativa, contando con valiosas bibliografías pormenorizadas dispuestas en orden cronológico, donde se percibe con mayor transparencia la evolución o dirección tomada por cada una de estas ideas o concepciones mediante diversos autores o tendencias, elaboración que en manos del insistente investigador José Ferrater Mora se mantuvo incansable hasta sus últimos días, y cuyo resultado se torna evidencia perceptible en cada consulta que se realiza sobre su amplio contenido impreso.

No obstante en su Diccionario de filosofía en referencia al significado del término ontología, en su última versión puntualiza:

"El autor de la presente obra ha usado 'ontología' - a diferencia de, e incluso en oposición a, metafísica- para designar toda investigacióncompuesta primariamente de análisis conceptual, crítica y propuesta o elaboración de marcos conceptuales- relativa a los modos más generales de entender el mundo, esto es, las realidades de este mundo. A su entender, las investigaciones ontológicas deben estar en estrecha relación con trabajos científicos, no habiendo una línea claramente divisoria entre hipótesis científicas de cierto grado de generalidad e hipótesis ontológicas. El renovado uso del término 'ontología' aparece asimismo en otros autores contemporáneos." (Ferrater Mora, 2004: 2626). 
Será vasto el trabajo creador desarrollado por Ferrater Mora, que destaca pulcramente por su esmero, entrega, dedicación y profundo espíritu crítico-analítico, marcadores constantes como elementos vitales.

El domingo 18 de julio del año 1976, aparece en la televisión española José Ferrater siendo entrevistado por el periodista murciano Joaquín Soler Serrano, en su emblemático programa $A$ fondo, en las palabras de presentación del invitado muy acertadamente Joaquín Soler Serrano señala: "José Ferrater Mora es una compleja personalidad filosófica", adjetivo que si es sopesado resulta tamañamente apropiado, puesto que el intelectual barcelonés dentro de la filosofía, partiendo del existencialismo desarrolla una propuesta de pensamiento integrador resultante de un proceso de arduo trabajo ontológico, además perennemente transversalizado por otras áreas del conocimiento filosófico consideradas en algunos casos distantes entre sí.

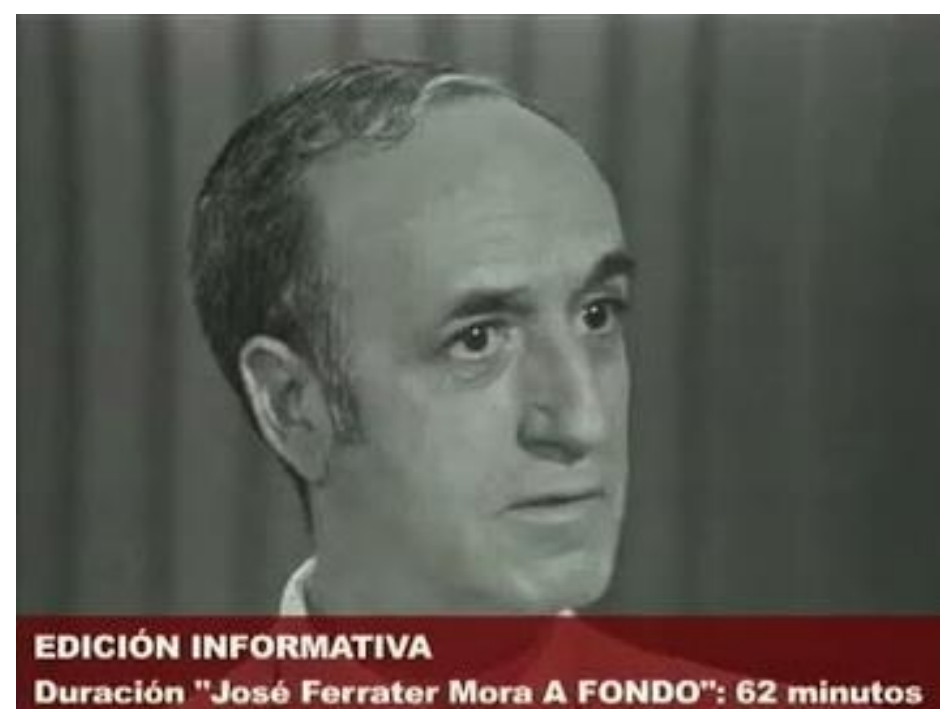

Ilustración 14: Reseña fotográfica de José Ferrater Mora en el programa televisivo $A$ fondo, de Joaquín Soler Serrano. (Fuente: www.youtube.com, FERRATER MORA, José - A FONDO (EDICIÓN INFORMATIVA). Tomado de: https://i.ytimg.com/vi/4p6NWsbMTww/hqdefault.jpg).

9. Visión de Ferrater Mora acerca de la ontología.

La visión acerca de la ontología según la definición plasmada en el Diccionario de filosofía, de Ferrater Mora, es asumida en esta investigación como piedra fundacional para el desarrollo y análisis del concepto, que está muy bien desarrollado desde su obra enciclopédica desde donde se ubican las siguientes ideas, que fungirán de guías de iniciación: 
"Lo que Aristóteles llamó <<filosofía primera>> (...) y luego se llamó <<metafísica >> parece tener dos temas de estudio. Uno es como Aristóteles lo llamó, <<el ser como el ser $\rangle>$ o < <el ente en cuanto al ente〉>. En este caso se toma $\langle$ el ser $\rangle$ en toda su

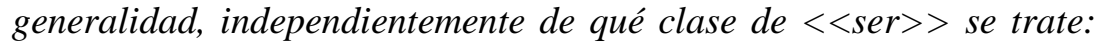
puede ser finito o infinito, material o no material, etc." (Ferrater Mora, 2004: 2622).

Dicha aclaración inicial, obedece a la preciosa necesidad de darse a entender, subrayando las diferencias y evitando mediante esta demarcación, los extravíos e imprecisiones sobre la observación del objeto ontológico. Prosigue del siguiente modo:

“Autores como Suárez y Fonseca estudiaron la metafisica en todos los
sentidos, pero prestaron gran atención a la metafísica como una
disciplina general de carácter $\langle\langle$ formal $\rangle>$. Algunas veces esta
disciplina general de carácter formal fue llamada de nuevo, como
Aristóteles hizo, <<filosofía primera $\rangle>$. A comienzos del siglo XVII
se empezó a proponer un nombre para este tipo de metafísica:
'ontología."." (Ferrater Mora, 2004: 2622).

Para continuar ampliando su reseña, remitiéndose de inmediato a la tradición de ese

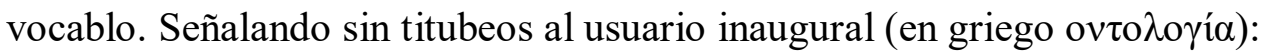

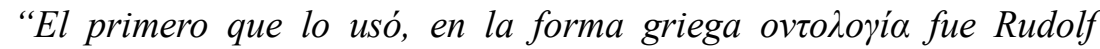
Goclenius en su Lexicon philosophicum, quo tanquam clave philosophiae fores aperiuntur (1613), pág. 16, pero limitándose a indicar: "ovtoגoyía, philosophia de ente». Veintitrés años después, el término ovtoגoyía (que se usó luego con más frecuencia en la transcripción latina ontología) fue empleado por Abraham Calovius (Calov) en su Metaphysica divina, a principiis primis eruta, in abstractione Entis repraesentata, ad S. S. Theologicam applicata monstrans, Terminorum et conclusionum transcendentium usum genuinum abusum a hereticum, constans (1636) [reimp. En los Scripta philosophica (1654), del mismo autor]. Según Calovius, la scientia de ente es llamada Metaphysica con respecto al "orden de las cosas", a rerum ordine, y es llamada (más propiamente) ovtoגoyía con respecto al tema u objeto mismo, ab obyecto proprio (Ferrater Mora, 2004: 2622, 2623).

Paralelo a Goclenius y Calovius reconoce oportunamente Ferrater Mora a otro importante filósofo con aportes a su comprensión del fenómeno ontológico; coincidencialmente también español, pero del siglo XVII, es el caso del madrileño Juan Caramuel de Lobkowitz, a quien introduce en su visión reconstructiva, a partir del año 1642. En su obra titulada Rationalis et realis philosophia (1642), Caramuel introdujo el

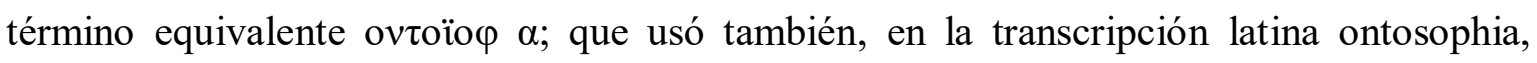
como equivalente a ontología. El objeto de la metafísica, escribió Caramuel, es en ens, y se

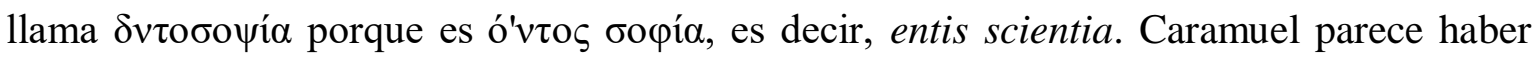


tenido una más clara idea de la naturaleza y requisitos de la "ontología-ontosofía" de la que tuvo Calovius.

Estas palabras orientan con crecida claridad las diferenciaciones iniciales surgidas en el campo intelectual, amén de señalar especificando autores y obras donde el docto catalán ha venido ubicando a lo largo de su perfil investigativo, elementos que han servido para la construcción y edificación sólida del término, en conjunto a su comprensión y aceptación del mismo. Luego añade:

"Se ha dicho con frecuencia - el propio autor de la presente obra lo dijo en ediciones anteriores de la misma-que el primer autor que usó términos como ontología y ontosophia fue Johannes Clauberg (16221665) en sus Elementa philosophiae sive ontosophia, scientia prima, de iis quae Deo creaturisque seu modo communiter attríbuntur (1647). Hemos visto que ello no es cierto. El propio Clauberg reconoce la precedencia de Calovius y Caramuel de Lobkowitz al respecto (op. cit., pág. 278 [la precedencia de Goclenius tiene escasa significación filosófica; menos aun la tiene la a veces mencionada de Jacobus Thomasius en su Schediasma historicum, de 1655]). Pero es cierto en todo caso que Clauberg destacó la importancia de la Ontología (u Ontosophia)” (Ferrater Mora, 2004: 2623).

José Ferrater Mora sistemáticamente ordena los elementos indispensables de toda esta trayectoria evolutiva, atendiendo detalles no solo profundos y superficiales aunque siempre pertinentes, sino que subraya pormenores marginales pero que permiten entrever los matices de su visión conceptual. En relación a ello especifica:

"La obra referida se divide en cuatro partes que tratan: 1) de los prolegómenos que dan razón de la «ciencia primera»; 2) de la didáctica o método de tal ciencia; 3) del uso de la misma en las demás facultades y en todas las ciencias y 4) de la diacrítica o diferencia entre ella y las otras disciplinas. Según Clauberg, la ontosophia (u ontología) es una scientia prima que se refiere (por analogía y no unívocamente) tanto a Dios como a los entes creados. Se trata de una

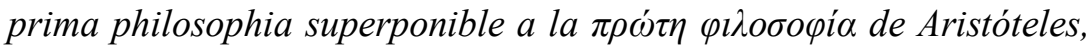
es decir, de una scientia quae speculantur Ens, prout Ens" (Ferrater Mora, 2004: 2623).

José Ferrater Mora reconoce el equívoco en el cual había incurrido, tras sostener afirmaciones con anterioridad a la investigación -o hallazgo-, del ahora error. Situación que finalmente le permite: reflexionar ante el saber, enriquecer un término tan significativo y un ejercitar la 'menudez significacional' de la diferencia prudente. Para continuar las especificaciones históricas, en el siguiente orden:

"En 1656, Clauberg publicó una obra titulada Metaphysica de Ente, quae rectitus Ontosophia, en la que define la ontosophia como 
quaedam scientia, quae contemplatur ens quatenus ens est. Se trata de la misma ciencia que es llamada «comúnmente» Metaphysica, pero que sería «más apropiado» llamar Ontología o scientia Catholica, eine allgemeine Wissenschaft, y Philosophia universalis. El ens de que trata la 108 ntología puede ser considerado como pensado (intelligibile), como algo (aliquid) y como la cosa (substantia). No podemos detenernos aquí en varias interesantes reflexiones de Clauberg de las que parece deducirse que la 108ntología es como una «noología» (véase Noología, Noológico), cuando menos en cuanto que la 108ntología trata de Alles was nur gedacht und gesagt werden kann (como escribe Clauberg, en alemán, dentro de la obra latina (costumbre, por lo demás, cada vez más frecuente en obras filosóficas académicas alemanas del siglo XVII)” (Ferrater Mora, 2004: 2623).

Las aclaraciones vinculadas al idioma o lengua empleada por estos autores, para la redacción y ulterior circulación de sus ideas, influirían seguramente en su recepción circulación y perdurabilidad, detalles como estos conllevaron a Ferrater Mora a su interés por los idiomas, reflejados en sus trabajos como traductor o la renovada traducción a sus trabajos, a una comprensión más cabal del binomio lengua-obra.

"En 1694 Clauberg publicó una edición anotada de los antes indicados Elementa philosophiae sive ontosophia, con el título Ontosophia, quae vulgo Metaphysica vocatur (conteniendo como apéndice un escrito titulado Logica contracta). En dicha obra indica Clauberg que el nombre ontosophia, "aunque no fue del gusto de las gentes doctas en las letras griegas, hizo su camino en el público", y luego reiteró las ideas expresadas en los Elementa y los nombres usados en la Metaphysica de Ente" (Ferrater Mora, 2004: 2623).

Este compendio analítico sobre el crecimiento, variaciones, los usos y abusos del vocablo, no detiene su marcha avanzando en su despliegue y profundización, tocando aspectos historiográficos, sociohistóricos, sociolingüísticos, discursivos; que permiten contextualizar, así como asumir una mejor comprensión de la vastedad lectoreflexiva en que se ejercitaba, con continuidad el filósofo barcelonés. Al sombrío respecto apenas iniciado, continúa aportando luces:

"Las «gentes doctas en las letras griegas» eran posiblemente humanistas y filólogos; «el público» no puede ser otro que el «público filosófico». $Y$, en efecto, este «público» respondió con simpatía al nuevo vocabulario. En 1653, J. Micraelius publicó un Lexicón philosophicum tcrminorum philosophis usitatorum, del que se publicó una segunda edición en 1662. Aunque no introdujo ningún artículo sobre "Ontología» $u$ "Ontosofia», habló de $\delta v \tau o \lambda o \gamma$.' $\alpha$ en el artículo

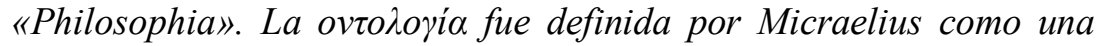
peculiaris disciplina philosophica, quae tractât de ente, si bien añadió: quod tamen ab aliis statuitur objectum ipsius metaphysica, lo que pareció un «retroceso» con respecto a Clauberg, y aun con 
respecto a Caramuel, ya que superponía 109ntología a metaphysica" (Ferrater Mora, 2004: 2623).

Las ondulaciones e inestabilidades de la ontología continuarían en los círculos intelectuales de la época, adquiriendo una resonancia que los filósofos e historiadores, incluido José Ferrater Mora, no se han permitido mirar de soslayo. De este modo llega el año de 1692:

"Etienne (Stephanus) Chauvin publicó un Lexicon philosophicum (que lleva bajo cubierta el siguiente título: Lexicón rationale sive Thesaurus philosophicus ordine alphabetico digestus, lo que explica que se lo haya citado a veces con el nombre Lexicon philosophicum y a veces con el nombre de Lexicon rationale). En esta obra, y en una segunda edición, aumentada, publicada en 1713, Chauvin introdujo un artículo sobre "Ontosophia», la cual definió del modo siguiente:

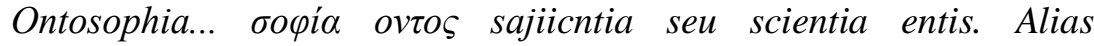
Ontología, doctrina de ente. Pero la mayor información sobre la ontosophia se halla no en el artículo «Ontosophia», sino en el artículo «Metaphysica» de la misma obra. En él escribe Chauvin que la metaphysica como 109 ntologí scientia seu universales quaedam Philosophia, es llamada por algunos Ontosophia u Ontologia, y estima que este uso es más apropiado por ser realmente scientia entis,

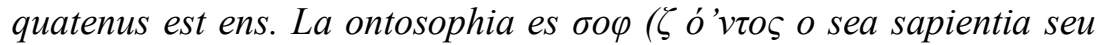

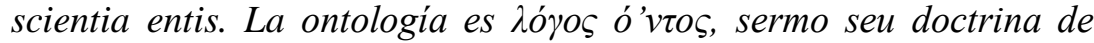
ente. Según Chauvin, la ontosophia parece ser propiamente la doctrina o ciencia del ente, y la 109ntología parece ser un sistema que incluye el método a usar en la doctrina del ente" (Ferrater Mora, 2004: 2623-2624).

El aporte intelectual de pensadores alemanes ha tenido en la historia de la filosofía un sitial de importancia, igual que era de esperarse ocurriera con el caso del trabajo intelectual de Ferrater y en adición de su definición ontológica. De este modo reconoce:

\footnotetext{
"Leibniz usó Ontología en su «Introductio ad Encyclopaediam arcanam» (apud L. Couturat, ed., Opuscules et fragments inédits de Leibniz, 1903, pág. 512), definiéndola como scientia de aliquo et nihilo, ente et non ente, re et modo rei, substantiel et accidente. M. Grabmann (Mittelalterliches Geistesleben, I, 1926, pág. 547) indica que Jean Baptiste Du Hamel usó el término ontologia en su obra Philosophia vêtus et noca, ad usum scholae accommodatae, in regia Burgundia olim pertractata (editio 3 multo emendatior), 2 vols., 1684, a veces llamada Philosophia Burgundica. Esto es cierto, pero también lo es que Du Hamel no parece dar gran importancia al nombre y a lo que él pueda significar. Menos interés muestra Du Hamel al respecto en la primera y segunda ediciones de dicha Philosophia Burgundica, tituladas respectivamente De consensu veteris et novae philosophiae libri dúo (1663) y De consensu veteris et novae philosophiae libri quatuor, seu Promotae per experimenta philosophiae pars prima (1675")" (Ferrater Mora, 2004: 2624).
} 
Conforme avanza el reconocimiento ferrateriano a sus influencias directas, al momento de ubicar la fundamentación teórica de su conceptualización ontológica, se tranquilizan y de inmediato vuelven a su oleaje las múltiples direcciones de las que ha sido atento estudioso, demostración con reiterada evidencia:

"Por otro lado, Antonio Genovesi [Genovese] usó ontosophia en su obra Elementa metaphysicae mathematicum in morem adornata. Pars prior. Ontosophia (1743), y Francis Hutclieson usó el término ontologia en su Synopsis Ontologiam et Pneumatologiam complectens (1742; 2. a ed., 1744, 3.a ed., 1749, 4.a ed., 1756, 5. a ed., 1762, 6.a ed., 1774). Ontologia fue introducida como término técnico en filosofía por Jean Le Clerc, en el segundo tratado titulado «Ontología sive de ente in genere», de sus Opera philosophíca in quatuor volumina digesta (5.a ed., 1722) (Julián Marías opina que sólo Jean Le Clerc, o Ioannis Clericus [1657-1737], puede ser considerado como un verdadero precursor de Wolff, pero la «prehistoria» del término 'ontología' que hemos bosquejado antes parece desmentir esta suposición)” (Ferrater Mora, 2004: 2624).

Llegando así Ferrater Mora a un punto neurálgico en la discusión ontológica. Es el caso de Christian Wolff, autor referencial al momento de pensar con detalle el saber filosófico en lo tocante a la ontología. Sobre Christian Wolff señala claramente: "En todo caso, fue Wolff quien sintetizó y popularizó la "ontología" en su Philosophia prima sive ontología methodo scientifica pertracta, qua omncs cognitionis humanae principia continentur" (1730). Prosiguiendo en los siguientes términos:

"Wolff define la ontologia seu philosophia prima como una scientia entis in genere, quatenus ens ens (Ontologia, § 1). La ontología emplea un «método demostrativo» (es decir, racional y deductivo) (ibid., § 2), y se propone investigar los predicados más generales de todos los entes como tales (ibid, § 8)" (Ferrater Mora, 2004: 2624).

Atiende a los rastros dejados por Wolff, observando a las obras y los pensadores que dieron continuidad a las aportaciones brindadas por este:

"Siguiendo las huellas de Wolff -el cual, según Pichler, siguió fundamentalmente a Clauberg (en sus Elementa) y a Leibniz (en su "De primae philosophiae emendatione", publicado en las Acta eruditorum, 1694), a tenor del propio Wolff (Ontología, § 7)-, Baumgarten habló de la ontología en su Metaphysica (1740), llamándola también ontosophia, metaphysica, metaphysica universalis, architectonica, philosophia prima, como "la ciencia de los predicados más abstractos y generales de cualquier cosa" (Metaphysica, § 4) en cuanto pertenecen a los primeros principios cognoscitivos del espíritu humano (ibid., § 5)" (Ferrater Mora, 2004: 2624). 
Toda esta persecución cronológica de la ontología conduce a José Ferrater Mora en su afán de comprensión, es aquí donde se le reafirmarían elementos existenciales, que le impulsarían hacia el valiente paso de izar su propia bandera deudora con la pluralidad propia de la historia:

"Esta prehistoria del término Ontología permite comprender, entre otras cosas, la posición de Kant con respecto a Wolff y hasta el hecho de que la "prueba anselmiana" fuera llamada por Kant con el nombre con que hoy generalmente se la conoce: "prueba ontológica" (...). Pero, en rigor, Kant se dirigió menos contra la "ontología" que contra la pretensión de erigir semejante "ciencia primera" sin una previa exploración de los fundamentos de la posibilidad del conocimiento, es decir, sin una previa "crítica de la razón"”" (Ferrater Mora, 2004: 2624).

Larga batalla terminológica, fuerte oficio el de la discusión ontológica, más aún cuando entre las principales potencias europeas se precisarán ontologías ligadas al poder tanto político como religioso, lo que aportaba otro matiz a estas indagaciones:

"En todo caso, es notorio que los autores que usaron Ontología u
Ontosofía tendieron a destacar el carácter "primario" de esta ciencia
frente a cualquier estudio "especial". Por eso si la ontología pudo
seguir siendo identificada con la metafísica, lo fue con una
"metafísica general" y no con la "metafísica especial". La ontología
fue -cuando menos en la llamada "escuela de Leibniz-Wolff"- la
primera ciencia racional por excelencia; por eso la ontología como
ontología rationalis podía preceder a la cosmología rationalis, a la
psychologia rationalis y a la theologia rationalis. Por medio del
nombre Ontología se designaba el estudio de todas las cuestiones que
afectan al llamado sermo de ente, es decir, al conocimiento de los
"géneros supremos de las cosas"" (Ferrater Mora, 2004: 2625).

Para Jose Ferrater Mora la ontología no consiste en una disciplina reduccionista ni tampoco un sistema que no pueda ser perfectible, que además puede contemplar rasgos de filosofía tradicional que pueden conjugarse con la filosofía de vanguardia. El análisis contemplará además que:

"La superposición de la ontología con la metafísica general representaría ya, por lo tanto, un primer paso hacia aquel mencionado proceso de divergencia de las significaciones en los vocablos 'metafísica y ontología'. En efecto, todo lo que se refiriese al "más allá" del ser visible y directamente experimentable, quedaría como objeto de la "metafísica especial", que sería, efectivamente, una transphysica. La "metafísica general u ontología" se ocuparía, en cambio, sólo de "formalidades", bien que de un formalismo distinto del exclusivamente lógico. Tal acepción es patente sobre todo en aquellas direcciones de la neoescolástica del siglo XIX que de algún modo tuvieron -cuando menos terminológicamente-contactos con el 
wolffismo. En todo caso, la citada expresión ha adquirido ya carta de naturaleza dentro de la neoescolástica. Por eso su nombre ha sido aplicado retroactivamente a todas las investigaciones sobre las determinaciones más generales que convienen a todos los entes, los trascendentales. Esta referencia a los trascendentales explica, por lo demás, el sentido en que fue tomada la ontología por Kant, quien pudo llegar a concebirla como el estudio de los conceptos a priori que residen en el entendimiento y tienen su uso en la experiencia" (Ferrater Mora, 2004: 2625).

Será la propia imprecisión que rige en la cuestión de los trascendentales la que haga que la ontología sea entendida de maneras diferentes:

"Por un lado, es concebida como ciencia del ser en sí, del ser último o irreductible, de un primo ens en que todos los demás consisten, es decir,, del cual dependen todos los entes. En este caso, la ontología es verdaderamente metafísica, esto es, ciencia de la realidad o de la existencia en el sentido más propio del vocablo. Por otro lado, la ontología parece tener como misión la determinación de aquello en lo cual los entes consisten y aun de aquello en que consiste el ser en sí. Entonces es una ciencia de las esencias y no de las existencias; es, como se ha precisado últimamente, teoría de los objetos. Algunos autores señalan que esta división entre la ontología en tanto que metafísica y la ontología en tanto que ontología pura (o teoría formal de los objetos) es extremadamente útil en la filosofía, y que el único inconveniente que presenta es de carácter terminológico; en efecto, arguyen tales críticos, conviene usar el vocablo Ontología" sólo para designar la ontología como ciencia de puras formalidades y abandonarlo por entero cuando se trata de la metafísica. La invención del término Ontología' ha expresado ya por sí misma la necesidad de tal distinción. Otros autores, en cambio, estiman que la división es deplorable, pues rompe la unidad de la investigación del ser (esse), tema de la metafísica y de la ontología o, si se quiere, de la metafísica-ontología” (Ferrater Mora, 2004: 2625).

La disputada ontología es adaptada a las inspiraciones reflexivas de un autor, encumbrándose como creación genuina, muchas veces con escasas reminiscencias, hacia la orientación primigenia del término:

"Como disciplina especial de la filosofía la ontología ha sido cultivada durante los siglos XVIII y XIX no sólo por autores que han seguido la tradición escolástica y la escuela de Wolff (o ambas), sino por otros autores y tendencias. Así ocurre con Herbart, donde la ontología es la ciencia que investiga el ser de los «reales» [...] con Rosmini, que hace de las ciencias ontológicas las ciencias que estudian el ser como es a diferencia de las ciencias deontológicas que estudian el ser como debe ser, etc. Nos referiremos a continuación a diversos modos de entender la ontología en el siglo XX, prescindiendo de las definiciones escolásticas a que hemos ya aludido" (Ferrater Mora, 2004: 2625). 
El análisis considera que para Edmund Husserl esta disciplina pasa a ser observada como una ciencia de esencias:

"La ontología puede ser formal o material. La ontología formal trata de las esencias formales, o sea de aquellas esencias que convienen a todas las demás esencias. La ontología material trata de las esencias materiales y, por consiguiente, constituye un conjunto de ontologías a las cuales se da el nombre de ontologías regionales. Ahora bien, la subordinación de lo material a lo formal hace, según Husserl, que la ontología formal implique al mismo tiempo las formas de todas las ontologías posibles. La ontología formal sería el fundamento de todas las ciencias; la material sería el fundamento de las ciencias de hechos, pero como todo hecho participa de una esencia, toda ontología material estaría a su vez fundada en la ontología formal" (Ferrater Mora, 2004: 2625).

Ahora bien, en consideración de Martin Heidegger, hay una ontología fundamental que es precisamente la metafísica de la existencia:

"La misión de la ontología sería en este caso el descubrimiento de "la constitución del ser de la Existencia". El nombre de fundamental procede de que por ella se averigua aquello que constituye el fundamento de la Existencia, esto es, su finitud. Pero el descubrimiento de la finitud de la Existencia como tema de la ontología fundamental no es para Heidegger más que el primer paso de la metafísica de la Existencia y no toda la metafísica de la Existencia. La ontología es, en realidad, única y exclusivamente, aquella indagación que se ocupa del ser en cuanto ser, pero no como una mera entidad formal, ni como una existencia, sino como aquello que hace posibles las existencias. La identificación de la ontología con la metafísica general ha de encontrar en esta averiguación del ser como trascendente la superación de las limitaciones a que conduce la reducción de la ontología a una teoría de los objetos o a un sistema de categorías" (Ferrater Mora, 2004: 2625-2626).

Explica José Ferrater Mora que en contraposición Nicolai Hartmann, sostiene que la justificación de la ontología consiste precisamente no en la pretensión de resolver todos los problemas, sino en cambio en el reconocimiento de lo que es metafísicamente insoluble. A partir de que:

"Por eso propone distinguir entre la antigua ontología sintética y constructiva, propia de los escolásticos y racionalistas, que pretende ser una lógica del ente y un paso continuo de la esencia a la existencia, y la ontología analítica y crítica, que se ocupa de situar en su lugar lo racional y lo irracional, lo inteligible y lo trasinteligible, más allá de todo racionalismo, irracionalismo, realismo o idealismo. El ente de que esta ontología trata, dice Hartmann, tiene un carácter mucho más general que el ser limitado de las teorías metafísicas aprioristas, pues abarca cuanto es y averigua en todos los casos las 
determinaciones que corresponden a todas las esferas de lo real" (Ferrater Mora, 2004: 2625-2626).

La visión ontológica de Ferrater Mora no se decanta a una posibilidad reflexiva, por el contrario, se enriquece ante cada novedad en las profundidades de las variaciones, en parte universalizando sus aprehensiones, siempre reconociendo la labor de todo aquel aporte; evitando obviar la relevancia de autores distintos a las posiciones tradicionales. De este modo aclara:

"El uso del término Ontología no se limita, como a veces se supone, a ciertos grupos de filosofías, racionalismo moderno, neoescolasticismo, fenomenología, filosofía de la existencia, entre otros. Se ha empleado también por filósofos de otras tendencias. Mencionaremos a continuación tres casos. El primero, el de J. Feibleman; el segundo, el de Lesniewski; el tercero, el de Quine. En relación con el último uso reseñaremos brevemente la discusión entre Quine y Carnap acerca de la legitimidad o ilegitimidad de plantearse cuestiones ontológicas, pues esta polémica arroja luz sobre el status de la ontología" (Ferrater Mora, 2004: 2626).

Las combinaciones del saber de la ciencia del ser, las conversiones y las convenciones son incorporadas en su idea y percepción, dando resultados innegablemente enriquecedores que al mismo tiempo le permiten desde su tribuna operar como propagador de estas aportaciones. En armonía a ello, apunta:

"Feibleman presenta una "ontología finita" destinada a mediar entre la actitud metafisica y la actitud positivista; se trata, como dice el mencionado autor, de un "positivismo ontológico". La ontología se convierte así en una serie de postulados que, aunque primariamente de carácter formal, son capaces de constituir una red conceptual que aprehenda la realidad. La ontología es entendida así como una "construcción" dentro de la cual adquieren sentido ciertos fundamentales conceptos metafísicos, tales como los de realidad, esencia, existencia, etc. Es una disciplina fundamental previa a toda investigación filosófica y científica. Stanislaw Lesniewski ha llamado ontología a la teoría y cálculo de clases y relaciones. La ontología se distingue, según Lesniewski, de la prototética (o cálculo proposicional) y de la mereología (o álgebra de clases, con exclusión de la clase nula). El desarrollo de la ontología da lugar a una "axiomática ontológica". Según Kotarbinski y León Chwistek, la ontología de Lesniewski, no obstante su carácter lógico-formal, tiene estrechas relaciones con varias partes de la filosofía aristotélica" (Ferrater Mora, 2004: 2626).

A partir de estos autores, las discusiones sobre lo ontológico franquean desde su ubicación junto a la lógica y se dirigen hacia establecer vinculaciones con áreas de estudio atentas al lenguaje como la lingüística, la semántica o la semiótica. Ferrater Mora no evade 
a estas discusiones y se vuelven recurrentes en su obra, en diversos formatos de presentación mostrara sus elucubraciones al respecto. En consecuencia sus apreciaciones sobre estos autores, no conllevarían la lejanía con la que observaría la obra del resto. Afirmando entonces:

"Quine ha propuesto dividir la semántica en dos partes. Una es la teoría de la referencia (que trata de los problemas relativos a la designación, a la denotación, a la extensión, a la coextensividad, a los valores de las variables, a la verdad). La otra es la teoría de la significación (que se ocupa de los problemas relativos a la sinonimia, a la analiticidad, sinteticidad, implicación e intensión). Dentro de este esquema la ontología pertenece a la teoría de la referencia, mientras que lo que dicho autor llama ideología pertenece a la teoría de la significación" (Ferrater Mora, 2004: 2626).

Aquí surgen entonces las necesarias precisiones sobre el término, propias del acontecer, Ferrater Mora se siente obligado a aclarar la acepción o variabilidad presentada, a modo de hacer justicia ante el esfuerzo intelectual llevado cabo por sus contemporáneos. Reconociendo que la ontología significa aquí ontología de una teoría y no coincide con el sentido "clásico" del vocablo. Desde este ángulo hay que entender frases tales como: "una cierta teoría interpretada implica una ontología". De esa forma, Quine ha expuesto estos puntos de vista en varios artículos. Observa José Ferrater Mora en ellos que cada forma de "discurso", implica una determinada ontología y "una teoría tiene que reconocer aquellas entidades -aunque sólo ellas- a las cuales las variables de cuantificación de la teoría deben ser capaces de referirse, con el fin de que las afirmaciones hechas en la teoría sean verdaderas". Pasando a detallar:

"El renovado uso del término 'Ontología' aparece asimismo en otros autores contemporáneos. Mencionamos entre ellos a Ernest Nagel y a Gustav Bergmann. Este último autor señala que el "Hay (existe)" cuantificado no tiene mucho que ver con la "existencia" de que habla la ontología tradicional, y propone un "patrón ontológico", a su entender más preciso que el de Quine, constituido por un lenguaje ideal (una ficción) susceptible de aclarar muchos problemas filosóficos" (Ferrater Mora, 2004: 2626-2627).

La fluida divagación llega a su contraste con la actualidad, así a las "cuestiones ontológicas" de Rudolf Carnap, internas y externas; los marcos son tomados como elemento referencial de este diseño conceptual. Acota Ferrater Mora al respecto:

"En cambio, R. Carnap ataca el problema de las cuestiones «llamadas falsamente ontológicas» mediante una distinción entre "'cuestiones' internas» $y$ " 'cuestiones' externas》. Las primeras son las que se suscitan dentro de un «marco» cualquiera («marcos» de 
entidades tales como «el mundo de las cosas», «el sistema de los números», «las proposiciones», etcétera.). Preguntar: «Este $x$, ¿es real o imaginario?», «¿Hay un número primo mayor que 100?», etc., son cuestiones internas. En cambio, las "'cuestiones' externas» se refieren al marco mismo: «¿Existe el mundo real?» (o mejor: "¿Existe la 'cosa mundo’ misma?»), "¿Qué clase de ser tienen los números (entidades subsistentes, seres ideales, trazos sobre el papel con los cuales se calcula)?». Estas cuestiones deberían contestarse aparentemente mediante una investigación que «trascendiese»los «objetos internos»" (Ferrater Mora, 2004: 2627).

El filósofo germano Rudolf Carnap, al igual que Ferrater Mora, desarrolló su trabajo filosófico y académico en áreas como la filosofía en general, la lógica y la semiótica, adicionalmente compartirán el interés en la ontología y en la influencia kantiana. En el Diccionario de filosofía se lee lo siguiente:

"Mas no es este el caso, según Carnap. Las cuestiones externas se refieren a asuntos desprovistos de contenido cognoscitivo y no son propiamente teóricas; son una decisión que el filósofo toma sobre el uso de un lenguaje, de modo que su formación como pregunta teórica es ambigua y desencaminadora. Las "'cuestiones' externas" (pseudoontológicas) no son propiamente "cuestiones" que necesiten justificación teórica porque "no implican ninguna aserción acerca de una realidad". La "cuestión" se reduce a la introducción o no introducción, aceptación o denegación de determinadas "formas lingüísticas" que, siguiendo el vocabulario anterior, llamaremos "marcos". Sólo así, piensa Carnap, se podrán admitir variables de tipos abstractos sin necesidad de adherirse al "platonismo" o a ninguna otra doctrina "ontológica". Carnap se opone, así, a la acusación de "realismo" hecha por Quine y otros autores, y niega que sea legítimo aplicar el término Ontología a la elección de una forma lingüística" (Ferrater Mora, 2004: 2627).

Sobre esta discusión, conocidísima en los círculos intelectuales dedicados a la ontología, Ferrater Mora concluye reflejando los aspectos que sobre el tema ontológico Rudolf Carnap hace sobre la verdad lógica y la verdad táctica. Cerrando este madurado debate interior, acorde a un plano expositivo del estatus, considerándole listo para ser difundido en su Diccionario de filosofía, dejando establecida su visión general de la ontología como se expresa en el siguiente enunciado: " $E l$ problema del status de las "entidades abstractas" como cuestión semántica se halla, según Carnap, sometido a las mismas restricciones apuntadas para el problema del "marco"; sólo las "aserciones internas" pueden ser justificadas ya sea empíricamente, ya sea lógicamente (pues Carnap sigue manteniendo una clara distinción entre las dos justificaciones, a diferencia de Quine, que no admite los límites tajantes entre verdad lógica y verdad táctica). Todo el error consistiría, pues, en tratarlas "'cuestiones' externas" (que no son propiamente "cuestiones") como " 'cuestiones' internas", en vez de referirlas a decisiones últimamente justificables por su resultado. El 
"principio de tolerancia" (en las formas lingüísticas) ha sido invocado una vez más por Carnap sin más restricciones que la cautela y el espíritu crítico en las operaciones asertivas" (Ferrater Mora, 2004: 2627).

Representa así un viaje antológico sobre las variaciones de lo ontológico. Será el tránsito desde las discusiones iniciales hasta las del pasado reciente, todas soportadas en el legado preservado en cada una de estas figuras, quienes disciplinadamente han venido cincelando su forma, nada ajena a la heterogeneidad pero válida, de enorme validez en lo que ha significado toda esta larga construcción, aun inacabada, de una expresión capital en el amor a la ciencia, puesto que es inmanente al ser, y en consecuencia inagotable en su riqueza e inaprensible en su finitud.

La entrevista de Teorema en su momento preguntó a José Ferrater Mora en cuanto al tema ontológico presente en su libro El ser y el sentido, que fuera ampliamente rebatido precisamente por Quine, de allí se resalta el siguiente fragmento:

"T.: Uno de los puntos fundamentales que tratas en este libro es el problema de «los haberes de la realidad», es decir, "lo que hay», tema sobre el cual ha reflexionado, especialmente el profesor Quine. ¿Podrías formular tu «criterio conceptual» de «compromiso ontológico»?

F.: La formulación del «criterio conceptual» de compromiso ontológico que aparece en $\mathrm{El}$ ser y el sentido requiere no pocas revisiones y refinamientos. Grosso modo, diré que un criterio conceptual de compromiso ontológico tal como entiendo requiere (por desgracia o por suerte, según como se mire) algo más (o distinto de) que un análisis semántico, aunque, por supuesto, no puede prescindir de la formulación semántica y hasta en gran medida está determinado $y$ condicionado por ella. Lo que ocurre es que un compromiso «ontológico» no tiene más remedio que «tomar posiciones» que por sí mismas no pueden ser -plenamente probadas, aunque sean más o menos plausibles. Mis posiciones al respecto (más exactamente: las posiciones que se derivan del criterio de compromiso adoptado y lo que condicionan la formulación del compromiso) son, por así decirlo, clásicas: por un lado (y desde el punto, de vista «metafísico») un naturalismo; por otro (y desde el punto de vista metodológico) un pragmatismo (con no poco de nominalismo entre los dos). "(1972: 97108).

La ontología como filosofía primaria forma parte primordial en la aplicación del método integracionista y en el análisis de las realidades y en los conceptos que Jose Ferrater Mora desarrolla a lo largo de toda su obra. Se puede inferir que el empirismo dialéctico tiene su propia ontología y es por esta razón que no hay una sola ontología para Ferrater Mora sino que la ontología va evolucionando de acuerdo con la realidad existencial. 
10. Reduccionismo, lógica y realidad.

10.1. Reduccionismo.

$\mathrm{Al}$ aspirar una respuesta concreta sobre el reduccionismo bajo la óptica ferrateriana, se hallará en la conceptualización desarrollada por José Ferrater Mora disponible entre las páginas del Diccionario de filosofía, del que se tomará como materia elemental la noción de reducción, desde donde el intelectual español expone sus visiones al respecto, enlistadas en el siguiente orden:

“ 1) En lógica se llama «reducción» a diversas operaciones. En

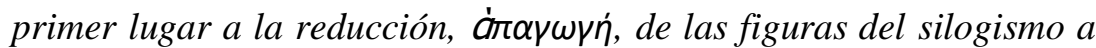
la primera figura, única que Aristóteles consideraba como bien fundada. En segundo a la abducción (Véase). Finalmente, al método de prueba indirecta llamado a veces razonamiento apagógico y con más frecuencia reducción a lo absurdo y reducción a lo imposible,

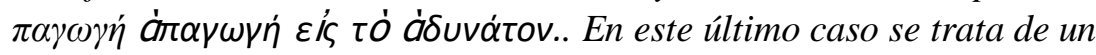
método indirecto de demostración que prueba la verdad de una proposición por la imposibilidad de aceptar las consecuencias que se derivan de su contradictoria..." (Ferrater Mora. 2004: 3025).

Esta explicación inicial atiende de lo general a lo particular, en este caso señalando como reducción a la diversidad de operaciones comprendidas así desde la lógica, la cual se bifurca primeramente en la reducción estudiada por Aristóteles -generada en un silogismo, concretándose en una primera figura-, secundada por la "reducción a lo absurdo" o "a lo imposible", también conocida como "método de prueba indirecta". En la primera de estas tres últimas nociones, tratase de un método de prueba o demostración del carácter de verdadero, evidenciado en una proposición, apoyado en derivaciones de su contradictoriedad:

“...Los escolásticos han usado la noción de «reducción» en varios sentidos. Cabe entender por 'reducción' la inclusión de una entidad dentro de un género o clase. Cabe entender también por ella la reducción de un silogismo a la primera figura (Véase). Cabe entender asimismo por 'reducción' la operación que hemos llamado «reducción a lo absurdo» o «reducción a lo imposible»; en este caso, lo que se «reduce» es un enunciado falso o contradictorio..." (Ferrater Mora, 2004: 3025).

Aunque al mismo tiempo, sean reconocidas de entrada las otras formas conexas de comprensión de tal punto, en tanto cargadas de proximidad como de valores específicos que le otorgan matices dejando en relieve la diferenciación evidente entre una y otra especificación, verbigracia la tildada de "reducción a lo imposible", en donde lo factible de 
reductibilidad es específicamente un enunciado de naturaleza netamente "falso o contradictorio":

“...Algunos suponen que la reducción al absurdo es absolutamente cierta y concluyente; otros, en cambio, la consideran menos cierta que una prueba directa. Al referirse a este punto, Peirce ha considerado la reducción -con el nombre de abducción- como uno de los tipos de inferencia. Sin embargo, Peirce manifiesta que no se puede confundir la apagoge tal como es definida por Aristóteles, y la reducción a lo imposible o método de demostración indirecta que afirma la validez de una conclusión por la asunción de su contradictoriedad..." (Ferrater Mora, 2004: 3025).

Para ilustrar desde un punto de vista lógico el recién expresado fragmento José Ferrater Mora decide asirse, de un ejemplo desarrollado por un referente clave en el tema, no es otro que el norteamericano Charles Sanders Peirce, quien se recordará es asumido junto al lingüista suizo Ferdinand de Saussure como padre de la teoría de los signos o semiótica moderna y fundador o creador del pragmatismo:

“...«Tomemos, por ejemplo - escribe Peirce-, la séptima proposición del primer libro de Euclides, la que afirma que sobre el mismo lado de la base $A B$ no pueden existir dos triángulos $A B C$ y $A B D$ de modo que $A C=A D$ y $B C=B D$. Euclides lo prueba mostrando que si hubiese dichos dos triángulos se seguiría de ellos que los ángulos $B D C$ y $B C D$ tendrían que ser iguales, así como desiguales. Pero justamente el proceso de razonamiento muestra que si hay dos triángulos $A B C$ y $A B D$ sobre el mismo lado de $A B$, y si $A C=A D$, entonces $B C$ no es igual a $B D$, lo cual muestra que no hay dos triángulos en los cuales $A C=A D$ y $B C=B D$, pues las cosas desiguales no son iguales» (Collected Papers, 2.612)..." (Ferrater Mora, 2004: 3025-3026).

Aunque en otros espacios, el lógico y filósofo Charles Sanders Peirce, defina los anteriores razonamientos concluyendo en proposiciones distintas a las señaladas, resumiendo en palabras de José Ferrater Mora la perenne posibilidad de "sustituir cualquier premisa por la negación de la conclusión,”. Relacionando sin titubeos ni medias tintas a la inferencia con la prueba apagógica:

“...En otro lugar, Peirce define el razonamiento o forma apagógica diciendo que «si $C$ es verdadero cuando $P$ lo es, entonces $P$ es falso cuando lo es $C$. De ahí que sea siempre posible sustituir cualquier premisa por la negación de la conclusión, con tal que la negación de aquella premisa sea sustituida al mismo tiempo por la conclusión. $Y$ de ahí, correspondiendo a todo argumento silogístico de la forma general: $S$ es $M, M$ es $P$; $S$ es $P$. Otros dos argumentos, a saber: Es falso que $S$ es $P, M$ es $P$. Es falso que $S$ es $M$, y $S$ es $M$; es falso que $S$ es $P$. Es falso que $M$ es $P$ » (op. cit., 2.475). Con lo cual, la inferencia está relacionada indudablemente con la prueba apagógica, y ello de 
un modo muy parecido a como la tercera figura lo está con la segunda (op. cit., 2.516)...”. (Ferrater Mora, 2004: 3026).

Ante tal argumentación silogística, surgen dos argumentos que llevan a establecer la relación ya expresada, entre prueba apagógica e inferencia. Al respecto advierte Ferrater Mora sobre la existencia de un modo exitoso de inversión aplicado al silogismo originario, además extrae de las ideas desarrolladas por Charles Sanders Peirce, que en este mismo modo tanto las conclusiones como las premisas de cualquier tipo son susceptibles de intercambio, adscribiendo como derivación del inicial signo negativo:

“...Sin embargo, sigue diciendo Peirce, hay un modo en el cual el silogismo ordinario puede ser invertido, y donde la conclusión y cualquiera de las premisas pueden ser intercambiadas adscribiendo signo negativo a cada una de ellas: es la forma en que las figuras indirectas o apagógicas del silogismo son derivadas de la primera, y en la cual el modus tollens es derivado del modus ponens» (2.718)." (Ferrater Mora, 2004: 3026).

El concepto de reducción pasará a ser considerado bajo otras miradas, la primera en sumarse es la visión conjunta de los filósofos y lógicos polacos Jan Lukasiewicz y su discípulo Józef Maria Bocheński, una reducción será un método de contraposición al de deducción, premisas expresadas por Jose Ferrater Mora desde el consiguiente fragmento:

“...La reducción es, según J. Lukasiewicz e I. M. Bocheński, un método que se contrapone al de la deducción. En la deducción se derivan unas proposiciones de otras por medio de reglas de inferencia. Ejemplo es:

Pedro fuma

Pedro tose

Pedro fuma y Pedro tose

En la reducción se deriva el antecedente de un condicional de la afirmación del consecuente. Ejemplo es:

Si Pedro fuma, Pedro tose

Pedro tose

Pedro fuma..." (Ferrater Mora, 2004: 3026).

Sigue la correspondiente ampliación y ataque frontal a cualquier posibilidad de desvarío por parte del autor; trae por ejemplo a colación la reducción concebida desde cuatro sentidos (presente en algunas de las cuatro siguientes modalidades: progresiva, regresiva, inductiva y no inductiva), explicando superficialmente cada uno de estos:

“...Según Bocheński, la reducción puede entenderse en cuatro sentidos, agrupados en dos fundamentales: a) La reducción puede ser progresiva (y consiste entonces en la verificación), o regresiva (y consiste entonces en la aclaración). b) La reducción puede ser 
inductiva (y consiste entonces en una generalización), o no inductiva (y no consiste entonces en una generalización).

2) En psicología se llama reducción de las imágenes al hecho de que una imagen u otro fenómeno parezca real..." (Ferrater Mora, 2004: 3026).

Señala así José Ferrater Mora de modo histórico, la diversidad de apreciaciones más sobresalientes acerca del reduccionismo a lo largo del tiempo, linealidad donde hace paradas sobre diversidad de ramas del saber, con una profundidad milimétricamente ajustada a la relevancia de tal punto en relación a la filosofía, tal como se acaba de percibir con la ciencia de la psicología, tratamiento contrario al otorgado en las próximas oraciones donde se apreciará la necesaria visión y revisión de puntos revestidos de un mayor interés para el estudioso barcelonés:

“...3) La reducción tiene un significado central en la fenomenología. La reducción es aquí el proceso por el cual se ponen entre paréntesis todos los datos, convicciones, etc., a los que se refieren los actos, para volver sobre los actos mismos. La reducción puede ser eidética o trascendental. En la reducción eidética se ponen entre paréntesis todos los fenómenos o procesos particulares con el fin de alcanzarse la esencia (Véase). En la reducción trascendental (llamada también propiamente «fenomenológica») se ponen entre paréntesis las esencias mismas para alcanzar el residuo fenomenológico de la conciencia trascendental. Nos hemos referido a la reducción en el sentido de la fenomenología con más detalle en los artículos Fenomenología y Husserl (Edmund). Añadiremos aquí que, según Husserl, el método de la reducción fenomenológica permite descubrir «un nuevo reino de la experiencia»-y hasta «crear» una nueva experiencia desconocida a los hombres antes de la fenomenología(cfr. Erste Philosophie, 1923/1924. Zweiter Teil: Theorie der phänomenologischen Reduktion, 1959, ed. Rudolf Boehm [Husserliana, VIII, pág. 163])." (Ferrater Mora, 2004: 3026).

Continuarán apareciendo elementos fundamentales inevitables para pasar a configurar una visión elemental, panorámica de nociones como reducción y reduccionismo que el caso del integracionismo propuesto por Ferrater Mora, y, rigurosamente apegado a la fidelidad hacia el método operacional donde prevalece la integración de corrientes encontradas, no resaltan los elementos por su pomposidad sino primariamente por su valor objetivo, definido pragmáticamente hasta la fecha de la redacción ferrateriana:

“...4) La reducción es también un método admitido en todas las llamadas «ciencias neutrales» o en todas aquellas filosofías que de algún modo han intentado colocarse «sin supuestos» frente a «lo dado». Por ejemplo, Avenarius habla de la necesidad de reducir la introyección, de suspenderla o ponerla entre paréntesis con el fin de restituir el concepto natural del mundo y las coordinaciones principales empiriocríticas. Por su lado, Theodor Ziehen, aunque 
negando formalmente las influencias de Avenarius y de su escuela, considera las "partes integrantes de la reducción» (Reduktionsbestandteile) como elementos situados más allá -o más acá- de la oposición entre lo material y lo psíquico. Las partes integrantes de la reducción son, pues, a la vez, partes integrantes de lo dado regido por las leyes gignomenológicas...) (Ferrater Mora, 2004: 3026).

Asumida entonces como método de familiar adopción en las conocidas como ciencias naturales -en algunos casos también denominada como ciencias de la naturaleza- y con similar privilegio entre y ante filosofías colocadas sin supuestos ante lo dado, José Ferrater Mora citando al filósofo germano-suizo Richard Avenarius -formulador de la filosofía del empiriocriticismo-, bien acompañado por Georg Theodor Ziehen, filósofo y psicólogo germano, afirma que, cabe destacar que las "partes integrantes de la reducción son, pues, a la vez, partes integrantes de lo dado regido por las leyes gignomenológicas". Afirmación a la que adiciona:

“... 5) En un sentido más general, aunque en varios puntos emparentado con las últimas acepciones mencionadas, la reducción es el acto o el hecho de transformar algo en un objeto considerado como anterior o más fundamental. La reducción puede referirse tanto a un objeto real como a un objeto «ideal». En el primer caso es una forma de la recurrencia por la cual un estado más desarrollado se convierte en un estado menos desarrollado. Por eso la reducción es llamada entonces también, según los casos, regresión o involución. [Sic"] (Ferrater Mora; 2004: 3026-3027).

En un marco más general, sin intenciones de dejar fluir generalizaciones desmedidas, se atreve Jose Ferrater Mora a atisbar una inminente claridad, la reducción es un acto o hecho de la transformación dada, que ha pasado a ser considerado de anterior, previo, preexistente o sencillamente más general. Cerrado entonces el caso primero llega el turno para un segundo caso, el que anunciará radicales diferencias:

"En el segundo caso, la reducción equivale al paso de lo fundamentado a su fundamento. Dentro de este último concepto pueden incluirse las múltiples teorías reduccionistas que han proliferado a lo largo de la historia de la filosofía. La tesis según la cual una realidad determinada «no es sino» otra realidad que se supone «más real»o «más fundamental» es la expresión común de todas las actitudes reduccionistas. Éstas tienen, sin duda, una justificación en el postulado de la necesidad de simplificación de las leyes, pero al mismo tiempo topan con dificultades derivadas no sólo de la irreductibilidad ontológica que resulta de una pura descripción de las capas de lo real, sino de las mismas exigencias teóricas en las ciencias". (Ferrater Mora, 2004: 3027). 
Reducción como resultado de la acción generada entre lo fundamentado, decantado ahora en fundamento. Apartado donde es permitido el acceso a "las múltiples teorías reduccionistas" que han venido proliferando sobre la prolongación de la tradición filosófica hasta los usos aplicables en la actualidad. Donde alguna realidad en particular pasa a ser, comúnmente, una supuesta realidad más fundamental o real; hecho sustentable en "la necesidad de" efectuar simplificaciones valederas sobre las leyes existentes:

"En efecto, aun cuando algunas veces puede ser considerada la reducción como «teóricamente posible»-por ejemplo, la reducción de la psicología a fisiología, de está a química y de ésta a física-, resulta que tal posibilidad se abre sólo por el hecho de que la consideración se ha situado automáticamente en otro nivel distinto, precisamente en aquel nivel que tiende a descartar ciertos contenidos de las respectivas ciencias. La reducción, frecuentemente en la filosofía, de lo real a lo ideal, chocó, pues, con obstáculos parecidos a los encontrados en la reducción inversa, sobre todo vigente dentro del naturalismo". (Ferrater Mora, 2004: 3027).

Las variedad de teorías reduccionistas han demostrado que si en algunos casos una reducción se muestre como posible en teoría ello no pasa a establecer la inevitable certeza de tal afirmación, por el contrario se ha evidenciado el impacto entre realidad e idealidad en gran número de casos; recordando lo ocurrido en reiteradas ocasiones con los practicantes del naturalismo. Prosigue la reflexión ferrateriana:

\footnotetext{
"Ahora bien ni el racionalismo clásico ni el naturalismo moderno y contemporáneo pueden ser considerados como reduccionistas en principio. Dentro de ellos puede darse tanto un reduccionismo como una teoría de la irreductibilidad (ontológica o simplemente descriptiva). Así, el reduccionismo materialista es combatido no solamente por las ontologías antirreduccionistas (del tipo de la de Boutroux o de la de Nicolai Hartmann), sino inclusive por las nuevas corrientes naturalistas, las cuales, como ocurre con J. H. Randall, Jr., no consideran incompatible la admisión de los «procedimientos científicos» como los únicos justificados, y la admisión de la riqueza, variedad y multiplicidad irreductibles de lo real". (Ferrater Mora, 2004: 3027).
}

Establece Ferrater un recorrido por los puntos de frecuente estudio en las investigaciones reduccionistas, añadiendo a los ya citados autores otros más próximos a su tiempo como es el caso del francés Émile Boutroux y el alemán Nicolai Hartmann, o como representación de las novedosas corrientes naturalistas, al americano John Herman Randall, Jr., o también al brasileño Euryalo Cannabrava:

"Según indica E. Cannabrava refiriéndose a uno de los tipos de reducción más insistentemente defendidos por el viejo naturalismo -el de los procesos psicológicos a procesos fisiológicos-, «nada impide que el pensamiento, por ejemplo, se desenvuelva de acuerdo con sus 
propias leyes, que definen las relaciones entre las diferentes fases del acto de pensar»; lo contrario es caer en una pura especulación metafísica bajo apariencia de demostración rigurosa ; es «incurrir en el grosero error lógico de confundir las condiciones necesarias con las condiciones suficientes de un proceso cualquiera»". (Ferrater Mora, 2004: 3027).

Es menester aclarar qué es lo que se entiende como reducción, de cara a cada aplicación de tal noción sobre algún escenario, de qué tipo es tal reducción, precisando en lo posible la mayor cantidad de elementos que expresen su imparcial descripción y sus rasgos para ser afirmada integralmente como ineludible reducción. Ernest Nagel introduce para estos casos las distinciones ya frecuentes de "selectiva, característica, constitutiva, completa" entre otras:

“Cuando se usa el término 'reducción' hay que aclarar sobre todo si por él se entiende la reducción de unos objetos a otros (reducción ontológica) o la reducción de unos enunciados a otros (reducción semántica). En este último caso debe precisarse qué tipo de reducción se propone: incompleta, completa, formal, cognoscitiva, etc. Nagel ha distinguido entre reducción selectiva, característica, constitutiva, completa, formal y epistémica”. (Ferrater Mora, 2004: 3027).

No solamente asumirá Nagel las anteriores limitaciones, sino que también otorgará importancia a la consideración de ciertos enunciados entre un número de dos o más ciencias, confirmados empíricamente, donde preferiblemente para garantizar la eliminación de algunos de los problemas comunes en el reduccionismo en tiempos iniciales, establece los siguientes señalamientos:

"Según el mismo autor, el problema de la reducción en las ciencias debe ser considerado siempre «en términos de las conexiones lógicas entre ciertos enunciados empíricamente confirmados» de dos o más ciencias dadas, por lo cual no se trata de la posibilidad o imposibilidad de deducir las propiedades de un sujeto de las propiedades de otro, ni tampoco de negar la existencia de ciertos fenómenos declarándolos ilusorios (por ejemplo, la temperatura, por el hecho de «reducirse» a elementos moleculares). Así se eliminan, según Nagel, varios pseudo-problemas que habían sido planteados por el antiguo reduccionismo, el cual no tenía en cuenta ni la diferencia entre «reducción lógica» $y$ «reducción ontológica», ni tampoco el hecho de que todo problema de reducción en las ciencias es un problema concreto, que se refiere a un estado determinado de la ciencia considerada". (Ferrater Mora, 2004: 3027).

Para Nagel, quien es una voz autorizada en cuanto a la puesta en práctica y elaboración teórica de aplicaciones válidas en reducciones triunfantes, la necesaria incorporación de la fecha para laborar algunas reducciones será el principal aporte en el qué se enfatizarán las reflexiones, siempre que su aplicación se sujete a la normativa 
prefijada por las investigaciones de Nagel, autor de The Logic of Reduction in the Sciences publicado en el año 1935:

\begin{abstract}
"Por este motivo, Nagel ha insistido recientemente en que «la cuestión de si una ciencia dada es reducible a otra debe hacerse más explícita por la introducción de una fecha definida». Si tomamos como ejemplo la llamada reducción de la electrodinámica a la mecánica en la física moderna, nos encontramos -dice Nagel-con que la termodinámica puede reducirse a una mecánica posterior a 1866, pero no es reductible a una mecánica tal como esta ciencia era concebida hacia 1700. Y, del mismo modo, una cierta parte de la química es reductible a una teoría física posterior a 1925, pero no a la teoría física vigente hacia mediados del pasado siglo." (Ferrater Mora, 2004: 3027).
\end{abstract}

Despide su análisis el académico barcelonés afirmando que es necesaria la admisión de una fecha que referencie la aplicación de alguna reducción y cuya introducción explicite tal posibilidad, donde el apego a lo temporal asume vital protagonismo. Serán las principales consideraciones, rubricadas por el pensador norteamericano de origen checo Ernest Nagel en relación a la actualizada noción de reducción, se pasará así a la vinculación de este término con sus aledañas concepciones de lógica y realidad.

10.2. Lógica y realidad.

El 'integracionismo' como método y sistema filosófico, posee de acuerdo a José Ferrater Mora, una base empírica y dialéctica. Por algo definió el carácter a su forma de pensamiento en su obra El ser y la muerte: "para perfilar el integracionismo: el empirismo dialéctico. Sugiero con ello una forma de pensar que aspira a ser fiel tanto a la lógica de los conceptos como a la estructura de la realidad" (Ferrater Mora, 1979: 20).

Desde esta perspectiva, un análisis al problema de la lógica y realidad, desarrolladas por el filósofo puede dar luces que profundicen las características de su sistema filosófico ya enunciadas en la sección dedicada al 'integracionismo'.

De las razones adicionales es que José Ferrater Mora dedicó dos obras impresas a la lógica y por otra parte pasó muchos años ejerciendo la enseñanza de la misma. Se puede observar parte de su planteamiento como se expresa en el contenido:

"El problema. Se ha suscitado con frecuencia la cuestión de cómo es posible que las leyes y reglas lógicas, que no tratan de los contenidos de las proposiciones o de las fórmulas, sino de su pura estructura, 
sean, sin embargo, útiles, y hasta indispensables, para referirnos a la realidad. A veces se ha supuesto que tal cuestión está intimamente emparentada con otra de carácter más general: la del modo como se puede establecer una conexión entre la realidad y el lenguaje. En gran medida esta suposición es correcta si tenemos presente que la lógica es, según se dijo, un lenguaje, y, más precisamente, uno de los lenguajes científicos -el lenguaje científico "básico"-. Pero la cuestión de la conexión entre la lógica -o el lenguaje lógico- y la realidad no es simplemente un aspecto parcial, de la cuestión de la relación entre la realidad y el lenguaje" (Ferrater Mora, 1957).

Tiene Ferrater Mora un planteamiento retórico que busca relacionar. Será propósito de las premisas del integracionismo buscar las relaciones entre sistemas y formas de pensamiento. Incluso cuando se trata del lenguaje y en este caso del lenguaje científico, que puede estar equidistante de ciertas realidades, pero que también es parte de la realidad, ya que la ciencia observa los fenómenos a través de sus métodos y no escapa incluso a los lenguajes característicos de la filosofía o de cualquier lenguaje otro lenguaje, inclusive el literario. Sin embargo, el pensador integracionista no deja de lado la complejidad de la solución al problema lógica-realidad:

"La solución dada a ésta no puede pues engendrar automáticamente una solución para aquélla. Por una parte, el problema "lenguajerealidad" ofrece multitud de aspectos que no interesan directamente al problema "lógica-realidad". Por otra parte, la cuestión "lógicarealidad' suscita dificultades especiales que no plantea la cuestión "Lógica-realidad". Es pues forzoso considerar esta última teniendo en cuenta como trasfondo la primera, pero sin hacer intervenir a ésta directamente.

El problema "lógica-realidad" es fundamentalmente un problema de aplicabilidad. Aplicamos la lógica -los esquemas lógicos, las leyes lógicas, las reglas lógicas - a la realidad en el sentido de que ordenamos lógicamente los enunciados relativos a lo real. Los marcos lógicos como tales no dicen nada sobre lo real, pero nada es posible decir acerca de ello sin ayuda de los citados marcos" (Ferrater Mora, 1957).

A pesar de que las realidades puedan ir en marcha, indistintamente de las leyes y los esquemas de la lógica, José Ferrater Mora reconoce que de igual manera son necesarios para el acompañamiento de la realidad. Tomando en cuenta que muchas realidades parten de sistemas de pensamiento o de pensadores que usaron métodos específicos para plantear y desarrollar problemas y su resolución desde esquemas y leyes aprendidos o asimilados. Por eso hace una relación 'problema-aplicabilidad' en el sentido de que puede analizarse un problema de la realidad y reconocerlo desde un marco o leyes de la lógica: 
"El tipo de aplicabilidad no es, empero, el mismo cuando se trata de las leyes lógicas (o principios lógicos) y cuando se trata de las reglas lógicas (o, más exactamente, metalógicas). Las leyes establecen los modos como alojamos nuestros enunciados en frases lógicas. Las reglas prescriben las maneras como usamos las frases lógicas, es decir, regulan nuestro lenguaje lógico. Por tal motivo, la cuestión "lógica-realidad" se plantea con toda propiedad sólo cuando nos referimos a las leyes, por medio de las cuales manejamos de un modo, más directo -aunque siempre considerablemente remoto-la realidad. Tales leyes no se reducen a los principios presentados en las secciones 11, 12 y 13, pero el lector puede tenerlos en cuenta para comprender las diferentes doctrinas propuestas con el fin de solucionar nuestra cuestión" (Ferrater Mora, 1957).

Toda realidad tiene su aplicabilidad, sujeta a principios lógicos, pero las reglas también tienen su propia aplicabilidad. Por eso Ferrater Mora expone que de acuerdo a la resolución del problema lógica-realidad, doctrinas que puedan abarcar la amplitud de las grandes o pequeñas filosofías:

"Doctrinas propuestas: Las teorías forjadas para resolver el
problema anterior han sido tan abundantes que hay en este respecto
un verdadero em barras du choix. Cada una de las grandes -y no
pocas de las pequeñas- filosofías ha querido hacer oír su voz en el
debate. He aquí algunas de las doctrinas más destacadas y a la vez
más discutidas. El acuerdo entre la lógica y la realidad es posible,
porque la realidad es últimamente de índole lógica -o, mejor, lógico-
racional. Las descripciones no lógicas se refieren entonces sólo a las
apariencias de la realidad, pero no al "'verdadero ser" o "verdadera
substancia" de ésta. Basta pues desarrollar todas las implicaciones de
la lógica para aprehender conceptualmente las estructuras
fundamentales de lo real" (Ferrater Mora, 1957).

Este dogma indica que la lógica en sí misma está construida por una realidad, de aquí se desprende que para referirse a lo verdadero, desde la sustancia o el ser desde las descripciones de la lógica, serían entonces meras apariencias sobre todo si se parte de lo conceptual. La lógica tiene una percepción de lo real, pero no lo enteramente real. Considerando que quien aplica un marco lógico parte de su propia realidad. Observando la segunda doctrina propuesta, se verá otro panorama:

"El acuerdo se debe a que el pensar lógico (entonces frecuentemente identificado. Con "la Razón" o con "el Pensamiento") y la realidad (en tal caso equiparada con "el Ser") son dos aspectos de un mismo y único "Ente" el cual se manifiesta a veces como "pensar-lógico" y a veces como "ser real"," (Ferrater Mora, 1957).

Aquí hay una separación conceptual de la lógica que se asimila con la razón. La lógica en este sentido es relacionada al pensamiento y está delimitada ante la realidad, 
mientras que la realidad se asimila con el Ser, pero que equivale a que ambos aspectos se integran en el "ente", convirtiéndose en una sola manifestación. La tercera doctrina plantea una idea similar, pero desde una visión paradójica.

"Se debe a que cuanto llamamos realidad es simplemente una proyección de nuestro pensar. En la medida en que este pensar es lógico, se concluye que la realidad es también lógica. De hecho, el vocablo 'acuerdo' resulta harto inadecuado para referirse a una concepción que ha suprimido previamente uno de los términos del problema" (Ferrater Mora, 1957).

Pareciera que este dogma no sólo integra lógica y realidad, sino que además considera que las mismas son parte de un sólo concepto. Concepto que reduce las visiones y sistemas filosóficos que contemplan distancias ontológicas de la razón y el ser. Para la cuarta doctrina, el panorama analítico adquiere diversidad:

"El sujeto que conoce no es ni un mero espejo que refleja pasivamente la realidad ni un centro activo y creador que la engendra: es una conciencia que ordena el supuesto caos de las impresiones de acuerdo -con ciertas categorías-. Como estas categorías responden a ciertas estructuras lógicas, se puede decir que lo que hay de lógico en la realidad es lo que el sujeto en tanto que sujeto cognoscente ha extraído previamente de las normas lógicas, imponiendo la lógica $-y$, con ella, el orden- a lo real" (Ferrater Mora, 1957).

Esta tesis enuncia que hay normas lógicas, pero no hace delimitación de esas normas dentro de lo que se denomina real. Más bien afirma que la lógica puede imponerse y como impostura ordena a la realidad o lo real, ya que la realidad puede estar relacionada a un caos que puede ordenarse desde la conciencia del ser. En la próxima doctrina, se observa una variable que la distingue de las anteriores:
"La realidad no es de índole lógica, pero está articulada y ordenada de tal forma, que los principios pueden, y deben, seguir fielmente tales articulaciones. La lógica no depende enteramente de la realidad, ni es una imposición de la mente a la realidad, pero las leyes lógicas están de algún modo fundadas en la estructura de lo real" (Ferrater Mora, 1957).

La separación de la realidad ante la lógica es que la realidad es independiente de que existan leyes, normas y principios relativos a la lógica. La realidad tiene su propia dinámica, pero también eso permite a la lógica no tener dependencia de la realidad, teniendo ambas una relación que distingue a cada una según su naturaleza.

Partiendo de que desde ambas concepciones, aunque distintas se puedan complementar, la siguiente doctrina expresa una visión: 
"Los principios lógicos son generalizaciones de observaciones efectuadas sobre lo real. A medida que se van ejecutando abstracciones sobre la realidad se van obteniendo relaciones cada vez más generales: el límite de este proceso -o este proceso proyectado idealmente al límite- da lugar a las leyes lógicas" (Ferrater Mora, 1957).

Tal afirmación muestra que los principios de la lógica son meras observaciones y abstracciones de lo real. El proceso de aplicación en tales observaciones de la realidad en sí mismo parte a realizar delimitaciones. Esas delimitaciones alejan la lógica de la realidad por su generalización u objetivación. Situación que se vislumbra en la próxima doctrina:

"Los principios lógicos pertenecen a una clase especial de "objetos", de los cuales no puede predicarse la existencia empírica ni la existencia supraempírica (o "metafísica"), sino otro tipo de existencia: la existencia "ideal" la "subsistencia", la "consistencia", la "objetividad", etc.." (Ferrater Mora, 1957).

Este dogma en particular comienza a categorizar la lógica de los objetos. Categorización que aleja los principios de la lógica de lo real, ya que hablar de "ideal", "subsistencia”, "consistencia" y "objetividad", términos que en general se refieren a las abstracciones, básicamente tratando de establecer otra realidad existencial.

Por lo que se ve, los principios lógicos tienen sus rasgos característicos, incluso, de acuerdo con lo que se enuncia en la próxima doctrina, un lenguaje.

"Los principios lógicos son, en último término, reglas del lenguaje. Ahora bien: del mismo modo, que se supone que el lenguaje es un conjunto de convenciones por medio de las cuales hablamos acerca de lo real, se concluye que las leyes lógicas son asimismo convenciones -convenciones "estilizadas"-. No hay pues conflicto entre lógica y realidad, pero no hay tampoco identificación de la una con la otra o derivación de una partiendo de otra. De hecho, no hay una lógica, sino muchas lógicas posibles; la adopción de una de ellas depende de su capacidad para operar sobre ciertos aspectos de lo real" (Ferrater Mora, 1957).

De acuerdo a esta consideración, al haber reglas del lenguaje en los principios lógicos, siendo las reglas meras convenciones, entonces no existe una diferencia significativa entre lógica y realidad, ya que los principios de la lógico en sí constituyen una sistematización de la realidad, ya que hay variedad de lógicas, no siendo la lógica algo elementalmente reduccionista, sino de amplia aplicación y valoración. 
Aunque pudieran existir diferencias entre los dogmas considerados hasta ahora, también se observa que la diversidad conceptual en tales formas de pensamiento contiene expresiones conciliatorias.

En el caso de la siguiente doctrina, se evidencia una ruptura o distancia considerable: "Los principios lógicos son simples tautologías. No se puede hablar de su coincidencia con lo real, pues son fórmulas enteramente vacías” (Ferrater Mora, 1957).

En este caso, hablar de principios lógicos es hablar de tautología, lo que en lógica proposicional equivale a "una fórmula sentencialmente válida" (1957). Si la visión de la realidad no es equivalente a ningún tipo de fórmula, la lógica y la realidad son equidistantes desde lo conceptual, siendo las fórmulas lógicas convenciones abstractas.

Ahora se verá una posición que enuncia una diferencia entre fórmulas lógicas y la simple tautología:

"Es posible operar sobre la realidad mediante formas lógicas, pero
ello no significa ni que tales formas sean meras convenciones, como
las que adoptamos al jugar al billar, al tenis, al ajedrez, etc., ni
tampoco que sean simples tautologías o fórmulas vacías. A diferencia
de las leyes naturales y de modo semejante a las leyes convencionales
de los juegos, las leyes lógicas pueden no ser obedecidas. Pero
análogamente a las leyes naturales, y a diferencia de las leyes
meramente convencionales, las leyes lógicas se imponen de algún
modo, pues son usadas en relación con el conocimiento de la
realidad" (Ferrater Mora, 1957).

La última doctrina considerada, establece que observar la realidad desde los principios de la lógica o sus fórmulas no son simples convenciones, ya que las mismas se desprenden de las realidades consideradas. Aunque hay una separación de la lógica y la realidad, ambas pueden integrarse en el uso que se le dé en su convención análoga.

José Ferrater Mora se ocupó de analizar todas estas formas de pensamiento expuestas, no una a una, pero sí el bloque, como se observa de acuerdo a lo que él consideró las posibles soluciones a los problemas que se plantean desde esas doctrinas:

"Analizar o discutir en detalle cada una de estas concepciones nos llevaría muy lejos. Nos limitaremos a formular algunas observaciones críticas sobre cada una de ellas y a destacar lo que en varias de ellas nos parece plausible. Las soluciones 1, 2 y 3 exigen un número demasiado crecido de suposiciones, todas ellas incomprobadas $e$ incomprobables. Además, es difícil comprender lo que significa que la realidad sea de "índole lógica", qué sea ese "Ente" que puede ser a la vez lógico y real, o cómo el pensar es capaz de engendrar cualquier cosa -y menos que ninguna "la" realidad-. Por si estos 
inconvenientes fueran pocos, tales soluciones postulan lo que se trataba justamente de demostrar: afirman que la lógica y la realidad concuerdan, porque son en último término lo mismo, o porque son manifestaciones de lo mismo, o porque una produce a la otra" (Ferrater Mora, 1957).

Ferrater Mora en su análisis crítico observa que las tres primeras doctrinas, además de entrar en algún tipo de contradicción por su forma enunciada, llevan a resultados improbables. Y su mayor contradicción es que busca establecer que la lógica y la realidad aluden a ser lo mismo, cuando es de suponer que los problemas tratan de descifrar o resolver lo contrario. Persistiendo con el análisis crítico, el filósofo catalán sigue exponiendo:

"La, solución (4) se presta a menos críticas. Es un hecho que el sujeto cognoscente no es un espejo pasivo -y completamente fiel- de lo que llamamos la "realidad". Pero decir que el sujeto cognoscente utiliza ciertas categorías para entender lo real no explica aún cómo y por qué tales categorías son calcadas de los elementos lógicos. El problema de la conexión entre la lógica y la realidad se retrotrae entonces a la cuestión de la conexión entre la lógica y las categorías" (Ferrater Mora, 1957).

El pensador integracionista observa en ese dogma algo más palpable a las que le preceden al concluir que sin ser lo mismo, hay una conexión entre la lógica y la realidad, que tampoco considera que sea una mera fórmula o convención tautológica. En el siguiente análisis hay una división de la doctrina considerada:

"La solución (5) contiene dos aspectos: (a) la suposición de que hay en la realidad algo lógico que permite reseguir sus articulaciones; (b) la afirmación de que de algún modo la lógica está fundada en el ser de lo real. El primer aspecto es muy discutible, sobre todo en la medida en que se acerca a la solución (1). El segundo aspecto es plausible; por desgracia, la doctrina según la cual las leyes lógicas tienen "un fundamento en la realidad" es harto vaga. Si con ello se quiere decir que lenguaje de la lógica forma parte de los lenguajes informativos, a los cuales sirve de base, no hay inconveniente en admitirla. Si se pretende sugerir que la estructura de la realidad determina unívocamente el conjunto de leyes lógicas adoptadas, hay que reconocer que choca con los modos efectivos como se lleva a cabo, tanto en el lenguaje ordinario como en el científico, semejante aplicación” (Ferrater Mora, 1957).

La consideración pertinente en este análisis conviene en que hay en la realidad algo de lógico y viceversa. Aunque esto sí no constituye una tautología, tampoco renuncia a ser vaga, ya que no deja lugar a que se presenten las respectivas contradicciones que se establecen en los lenguajes, incluyendo el ordinario y el científico. Por lo tanto se sigue 
presentando una problemática al tratar de considerar una solución a la cuestión respectiva entre la lógica y la realidad. Esto también se puede observar con su obvia diferencia en el consiguiente análisis:

"La solución (6) puede explicar la génesis psicológica de ciertas leyes lógicas; poco o nada dice, en cambio, acerca de nuestro problema. Por otro lado, la observación empírica por sí sola no permite alcanzar nunca los principio lógicos ni, en general, ninguna proposición sobre los llamados por algunos "objetos ideales-' (lógicos, matemáticos, etc.). Así que la realidad sea de "índole lógica", qué sea ese "Ente" que puede ser a la vez lógico y real, o cómo el pensar es capaz de engendrar cualquier cosa -y menos que ninguna "la" realidad-. Por si estos inconvenientes fueran pocos, tales soluciones postulan lo que se trataba justamente de demostrar: afirman que la lógica y la realidad concuerdan, porque son en último término lo mismo, o porque son manifestaciones de lo mismo, o porque una produce a la otra. Así como las propiedades de los triángulos con los cuales operan los geómetras no pueden comprobarse jamás en la realidad, tampoco las leyes lógicas son comprobables por el mismo camino. Lo único que puede decirse en abono de dicha solución es que ciertas leyes lógicas y las relaciones matemáticas pueden concebirse como proyecciones ideales, pero ni esto sucede con todas ni, una vez obtenidos los límites buscados, sabemos por qué tales límites, que sobrepasan toda observación, pueden ser manejados para ser aplicados a ulteriores observaciones" (Ferrater Mora, 1957).

Aunque pareciera que el análisis al problema puede tener una concepción más compleja que los anteriores, hay un señalamiento simple por parte de José Ferrater Mora que sin pretender al reduccionismo, señala en sí que las leyes y principios de la lógica constituyen proyecciones ideales y nunca concluyentes. En el próximo análisis incorpora la ontología:

"Las diversas formas de la solución son respuestas al problema sobre el status ontológico de las -leyes ideales-; como la solución (6), la (7) dice pues poco acerca de nuestro problema. Puede alegarse que, puesto que los principios lógicos no "'existen", sino que "subsisten" $o$ "consisten"-, la cuestión de su aplicabilidad a lo real es idéntica a la cuestión de la relación entre la idealidad en general y la realidad, y que puede afirmarse, según los casos, su coincidencia última, su paralelismo, etc. Estimamos, empero, que una solución no puede consistir en plantear otro problema susceptible de diversas otras soluciones y que, a menos de ser refinada considerablemente, la doctrina de la "subsistencia" no es necesaria: la cuestión de las "descripciones" que no describen nada y que a pesar de, esto son lógicamente admisibles, puede resolverse $-y$ ha sido resuelta- de otros modos menos inútilmente complicados. Por desgracia, no podemos extendemos aqui sobre un problema que desbordaría el nivel elemental de nuestra exposición” (Ferrater Mora, 1957). 
Parece que Ferrater Mora complica la relación entre lógica y realidad al analizar y mostrar que las doctrinas consideradas en vez de dar respuesta o solución al problema planteado, procede es a elaborar un nuevo problema desde su concepción ideal. No puede haber solución si desde esa solución se plantea un problema que implicaría la creación de una nueva doctrina, sobre la cual sería una elaborada propuesta que conllevaría a un análisis y exposición mucho mayor al que de forma primaria se expone. En la solución siguiente, se expone otro análisis de lo que considera José Ferrater Mora un aspecto complejo referente al lenguaje:

"La solución (8) es correcta en tanto que destaca que las expresiones lógicas pertenecen a un lenguaje. Olvida, empero, que aun las reglas lógicas no son enteramente arbitrarias y convencionales, sino que están guiadas por ciertas exigencias, las cuales vienen determinadas, en último término, por el conocimiento de la realidad -o, si se quiere, por los grupos de teorías forjadas con vistas al conocimiento de la realidad-. La convencionalidad y "arbitrariedad", por lo tanto, además de manifestarse menos aún en las leyes que en las reglas, opera sólo cuando se manejan símbolos sin significación, pero no -o mucho menos- cuando los símbolos son interpretados. Es cierto que no hay un solo, sistema lógico, sino varios posibles sistemas lógicos. Mas la elección de un sistema, por convencional que éste sea, no es a su vez una operación convencional" (Ferrater Mora, 1957).

Según el filósofo español, al hablar de soluciones correctas en un lenguaje de expresiones lógicas, están estas expresiones signadas por la realidad, que esa lógica y esa realidad están relacionadas por un lenguaje en común, pero que no debe desconocerse que existen otros lenguajes o sistemas que pueden operar en conjunto.

Ahora se observa un cambio en el análisis por parte del pensador catalán:
"La solución (9) ofrece dificultades técnicas que no podemos desarrollar aquí. Apuntaremos sólo que los límites que se han descubierto para llevar a cabo una axiomatización completa de ciertos sistemas formales, impiden que la lógica entera sea una ingente tautología y abren el camino para el descubrimiento incesante de nuevas fórmulas y leyes" (Ferrater Mora, 1957).

Este cambio obedece a la consideración de que Ferrater advierte una contradicción en sí de que los sistemas lógicos son meras o simples tautologías, quizás pensando en sistemas o lenguajes de la lógica desarrollado de acuerdo a ciertas leyes que requieren un análisis riguroso o detallado, exponerlo significa considerar axiomas y formalidades que de ninguna manera obedecen a las tautologías que el problema en sí mismo enuncia. Esas 
consideraciones del pensador catalán se conectan de forma indefectible con la solución número diez, de la cual acota:

"La solución (10) es más sutil que las otras y contiene, a nuestro entender, mucho que debe ser admitido como válido. Sin embargo, no destaca los motivos fundamentales por los cuales se supone que las formas lógicas no son ni meras convenciones lingüísticas ni invariantes que tienen un fundamento objetivo sólo en la propia lógica. Además, aunque la solución reconoce la distinción entre leyes y reglas lógicas, no parece que la subraye suficientemente. Parece pues conveniente ensayar una solución de carácter más amplio" (Ferrater Mora, 1957).

Es evidente que José Ferrater Mora, a pesar de estar de acuerdo en la amplitud de esta solución al problema de la lógica y la realidad, de igual forma no deja de subrayar que ninguna es concluyente, que no se logra alcanzar una forma absoluta a pesar de las distinciones que hay entre las leyes y las reglas de la lógica sea cual fuere. Por eso dispone de un "Ensayo de solución" como ahora se verá expresado:

"Ensayo de solución: Muchas de las soluciones fallan, porque consciente o inconscientemente tienden a suponer que lógica y realidad son dos "cosas" que deben relacionarse de alguna manera, ya derivando una de la otra, ya encontrando un común fundamento para ambas. Otras soluciones son defectuosas, porque separan tan completamente la lógica de la realidad, que la aplicación de la primera a la segunda resulta luego inconcebible. Otras, finalmente, son inadmisibles, porque en vez de centrar la cuestión en la aplicabilidad mencionada prefieren explicar lo que son las leyes lógicas, o bien de qué modo se originan en el espíritu de quienes la usan" (Ferrater Mora, 1957).

Este párrafo inicial deja en evidencia que el problema de la lógica y la realidad no debe dejarse a consideraciones de carácter extremo. Pudiera observarse la aplicación de su sistema integracionista al exponer su visión en este tema tan amplio y complejo. No hay posturas absolutas, pero tampoco vagas o simplistas. Como se verá en los próximos párrafos de este ensayo, las acotaciones de Ferrater Mora obedecen a su visión de integrar incluso sistemas, leyes, reglas que a pesar de las diferencias, existen formas de ordenación, no solamente desde el lenguaje que les ha sido conferido, ya que de acuerdo a su análisis no todo lo que se considera desde las convenciones o desde las normas debe adecuarse a un sistema rígido, sino más bien encontrar una adecuación para lograr modos de ordenación, precisamente en la siguiente acotación se observa:

"Ahora bien: la lógica y la realidad no sólo no pueden ser dos "cosas" relacionadas entre sí, mas tampoco son respectivamente una forma y un contenido al cual aquélla se aplica. 'Lógica' es, por lo 
pronto, el nombre que se da a ciertas operaciones por medio de las cuales describimos ciertos modos posibles de ordenación de realidades, efectivas o meramente posibles. A su vez 'realidad' es, por lo pronto, el nombre que se da a ciertos modos posibles de comportamiento de lo dado, a nuestras percepciones o inferido mediante nuestras percepciones. Así consideradas, la lógica y la realidad constituyen dos órdenes-órdenes diversos, múltiples, cambiantes según las varias disposiciones de sus partes. Por este motivo no puede decirse que las expresiones de que se vale la lógica sean entidades "subsistentes" o "consistente", fórmulas vacías de todo, contenido, convenciones más o menos cómodas, normas lingüísticas, o idealizaciones de nuestras observaciones o experiencias. La adecuación de, lógica a la realidad es la adecuación entre dos modos de ordenación" (Ferrater Mora, 1957).

El filósofo barcelonés resuelve en este ensayo de solución, desarrollando a través del concepto de lógica y realidad, plasmando su visión. La lógica obedece a 'posibilidades' de ordenación de la realidad. En lo que respecta a la 'realidad' corresponde a modos de ‘comportamiento' de acuerdo a las percepciones y ambas a su vez son 'órdenes' sin que sean iguales, sino que obedecen a sus propias consideraciones, aunque ambas se complementen. Ahora se verá una posible forma de relación entre ambas 'órdenes' como se señala a continuación:

"Sucede de este modo que la lógica se relaciona con la realidad no en la forma de una copia ni siquiera en la de una analogía, sino de un modo isomórfico. Las operaciones lógicas, y en particular las leyes lógicas, se aplican pues al orden de la realidad -o a los distintos órdenes de la realidad de modo parecido a como "aplicamos" un mapa a la realidad para nuestra mejor orientación en ella. El mapa nos proporciona un cierto conocimiento de lo real, pero no nos dice lo que la realidad es, sino únicamente cómo se halla estructurada -o, si se quiere, los distintos modos como puede ser estructurada-. Mediante la lógica cuadriculamos, por así decirlo, lo real. A tal efecto usamos ciertas convenciones, por cuanto lo real puede cuadricularse de muy diversos modos. Pero el que unas convenciones sean más satisfactorias que otras depende en considerable medida de la propia realidad "(Ferrater Mora, 1957).

Este texto indica el modo de relación de la lógica y la realidad. La lógica no busca sustituir a la realidad dada, ya que no corresponde a una simple analogía. En todo caso, la lógica da una visión de esa realidad de acuerdo a unas reglas o convenciones. Pero a la vez esas convenciones van a depender de la misma realidad a considerarse. Ahora se deberá considerar cuál es el producto de esa enunciada relación isomórfica:

"Con ello obtenemos dos ventajas. En primer lugar, no tenemos que separar por completo las diferentes ordenaciones de hechos, del lenguaje lógico mediante el cual las describimos, o en el cual las 
alojamos. Las formas lógicas siguen refiriéndose a los hechos, aunque de modo indirecto, pues so limitan a ordenar las distintas estructuras en las que pueden presentarse los hechos. En segundo término, no nos vemos obligados a establecer ninguna identificación -empírica o metafísica- entre la lógica y la realidad. Ambas poseen su propio modo de "ser" y, junto, a ello, sus propios modos de ordenación. Por eso podemos hablar lógicamente acerca de lo real sin por ello suponer ni que imponemos -por convención o por necesidad-nuestro pensar lógico a la realidad, ni que nos limitamos a reflejar pasivamente las estructuras de esta realidad" (Ferrater Mora, 1957).

Se deduce que desde la relación de la lógica y la realidad no hay imposturas de algún tipo que delimiten ambas 'órdenes', fundamentado en que no hay una demarcación empírica entre la una y la otra, porque cada una tiene su estructura y lenguaje. Pudiera decirse que cada una tiene su dinámica y sus formas, pero de ningún modo una se impone a la otra. José Ferrater Mora agrega a modo de cierre:

"A las citadas dos ventajas se agrega otra: la de poder entender de un modo sumamente flexible el mencionado concepto fundamental de "aplicabilidad". En efecto, la lógica no es simplemente aplicable a lo real; es aplicable a los órdenes de lo real de muy distintas maneras y en muy varios niveles. Esto explica que la aplicabilidad de la lógica sea tanto mayor cuanto más susceptible de ordenación sea el orden al cual se refiere. Así, la aplicabilidad de la lógica es máxima en la matemática, menor en la física o en la biología, y escasa (aunque no inexistente) en el lenguaje de la vida cotidiana" (Ferrater Mora, 1957).

El tema de la aplicabilidad de la lógica en la realidad es definible en grados, de acuerdo a las disciplinas o áreas de estudio en las cuales pueden ser utilizadas. Y si bien es cierto que se usa de manera más amplia en las matemáticas o en el lenguaje de las ciencias que estudian la naturaleza y la materia, pero de forma menos aplicable en el lenguaje de la vida cotidiana. Considerando que en la filosofía hay diversos sistemas, métodos, corrientes y que en esa variedad hay diversos lenguajes, es de prever que existan modos estructurales no considerados en este ensayo de solución y en esta exposición que hace Ferrater Mora sobre la lógica y la realidad.

El "Integracionismo" como ya se ha establecido con anterioridad es el sistema aunque en algunas ocasiones presentado como método- filosófico creado por Ferrater Mora en el siglo XX. En muchas de sus obras lo expuso y a lo largo de los varias décadas lo fue extendiendo, modificando, reescribiendo y es así que alcanza su evolución descrita en sus últimas obras publicadas en vida. 
El presente trabajo de investigación analiza la entrada que José Ferrater Mora escribió en su obra enciclopédica Diccionario de filosofía. Sin embargo, este análisis se desarrolla en consulta y diálogo con varias de sus obras escritas, en las que expone -a través de puntualizaciones- el integracionismo, en su determinación de consolidar un método, que lo distingue en el vasto universo de la filosofía universal.

En la próxima sección que corresponde a la filosofía integracionista, se analizará los aspectos contenidos en el concepto elaborado por Ferrater Mora que está citado en su Diccionario de filosofía. Ese análisis permite observar la conexión de temas pertinentes entre el integracionismo, filosofía existencial, ontología y tanatología ferrateriana, que para los efectos de la presente tesis, servirá para reforzar los elementos de la filosofía existencial presentes en el pensador catalán y su método filosófico.

\section{Filosofía integracionista.}

\subsection{El método.}

Como ya se ha hecho mención José Ferrater Mora ha propuesto el término 'integracionismo' para expresar a la vez su método y su punto de vista filosófico. Éstos se han desenvuelto en tres distintas etapas.

"En la primera se trataba de evitar los escollos y las insuficiencias en que caen normalmente dos tipos de pensamiento: El que presta particular, si no exclusiva, atención al sujeto humano, a la existencia humana, a la historia humana etc., y el que presta particular, si no exclusiva atención a las realidades naturales dentro de las cuales se encuentran los sujetos humanos. Estos dos tipos de pensamiento se han manifestado en varias contraposiciones: conciencia-realidad; pensamiento de la realidad-realidad pensada o investigada, y de un modo general (aunque vago), sujeto-objeto" (Ferrater Mora, 2004: 1865).

Desde el comienzo Ferrater Mora puntualiza que su método filosófico no es exclusivista, que no se permite establecer excesos o tomar partido por un tipo de pensamiento. Incluso recalca que hay escollos o insuficiencias en otros tipos de pensamiento que divide en dos, haciendo referencia a la existencia humana (tópico abordado en las diversas corrientes filosóficas) y los sitúa contrapuestos a los pensamientos filosóficos que centran su atención a las realidades naturales. 
A este respecto se puede considerar una cita de Alain Guy:

"Dado su espíritu perpetuamente insatisfecho e hipercrítico, Ferrater Mora escapa a cualquier etiqueta, pero su meditación admite la denominación de «integracionismo». Su método es un «empirismo dialéctico» que se inscribe en el marco de un «completo relativismo» (El ser y el sentido, p. 319) y que humildemente se reconoce siempre susceptible de revisión, muestra de la especial aversión del filósofo hacia todo dogmatismo. Ferrater Mora se propuso muy pronto elaborar «una ontología general de la realidad» (El sentido de la muerte, p. 63) que integrará todos los conflictos de la existencia humana y todos los aspectos de lo real"' (Guy, 1985: 360).

De acuerdo a esta lectura, hay dos grandes bloques de pensamiento filosófico y ambos están en oposición. El primer bloque conciencia-realidad, el segundo bloque pensamiento de la realidad-realidad investigada, pero asoma un tercer bloque, quizás desde una perspectiva dialéctica, una síntesis que Ferrater denomina sujeto-objeto a modo general.

El concepto sigue ampliando los bloques en las categorías que se ven a continuación:

"Los contrapuestos movimientos filosóficos pertinentes han recibido varios nombres, más o menos adecuados: personalismo - naturalismo, antropologismo - fisicalismo, existencialismo - cientificismo, y de un modo también general (y no menos vago), idealismo - realismo. Es común a estos tipos de pensamiento y a estos movimientos partir de realidades que estiman absolutas, y es muy frecuente en ellos juzgar que las realidades que las concepciones opuestas colocan en primer plano son derivables de las primeras, explicables por las primeras o simplemente son pseudo - realidades" (Ferrater Mora, 2004: 1865).

José Ferrater Mora vuelve a reiterar sobre el común de los movimientos filosóficos, que en principio agrupó en dos grandes bloques, que tienen la tendencia a situarse en realidades o concepciones absolutas. Incluso los nombres que describen estas denominaciones son más o menos adecuados, es menester recordar que en su concepto del existencialismo Ferrater Mora denota que se ha abusado tanto del vocablo existencialismo que, como han indicado varios autores allegados a esta tendencia (entre ellos Jean-Paul Sartre), ya no significa apenas nada; como personalismo-naturalismo, antropologismofisicalismo, existencialismo-cientificismo y en modo general idealismo-realismo.

El filósofo dispone que todas estas tendencias tiendan a juzgar en su postura a quien se contrapone en su visión de la realidad y por lo tanto se constituyen en acreedores de la verdad. Aquel que tiene la verdad es quien expresa la "realidad" mientras que las tendencias juzgadas constituyen las "pseudo-realidades". 
Es desde este marco conceptual que José Ferrater Mora genera la tesis principal de su propio sistema filosófico como se ve en el siguiente fragmento:

"En una etapa ulterior, el integracionismo ha operado no con
doctrinas filosóficas, sino con conceptos o grupos de conceptos. Las
realidades que aparecen, o que se presentan, como primeras, o
primarias -conciencia, objeto; realidad humana, realidad natural,
etc.-, son expresables mediante conceptos que funcionan a modo de
conceptos-limites y que, por tanto, no aspiran a tener 'denotata",
(Ferrater Mora, 2004: 1865).

La referencia clave es que el integracionismo opera de forma marginal a las doctrinas filosóficas. En otras palabras, el integracionismo no es una doctrina. Como no es doctrina tiene como objeto ser referencial, ser constructiva y darle profundidad a las ideas. Trabaja con grupo de conceptos, y su funcionamiento obedece a conceptos límites. Al no constituirse en doctrina, no establece realidades absolutas.

Sin embargo, José Ferrater Mora reconoce que el integracionismo trabaja con las realidades que se aparecen o se presentan como realidades primeras o primarias, al igual que lo hacen las corrientes filosóficas ligadas al existencialismo.

Trabajar conceptos o grupos de conceptos no necesariamente ubica a un sistema filosófico particular en una corriente, pero sí es posible identificar las influencias de esos conceptos o grupos de conceptos en un método o concepción filosófica que no se denomine a sí misma como una corriente absoluta de pensamiento.

El integracionismo, al igual que todo sistema filosófico tiene sus aspiraciones como a continuación se lee en su consiguiente desarrollo:

"Consideremos, como ejemplo, los conceptos expresados en los predicados (o pseudopredicados) 'es real' y 'es ideal', donde 'es real' se dice de un objeto físico y 'es ideal' se dice de un significado de una proposición. Lo que el integracionismo aspira a hacer en este caso no es definir absolutamente la «entidad»-o mejor, el predicado (o pseudopredicado) - en cuestión mediante una serie de predicados «unilaterales», sino situarla (véase Situar) dentro de una cierta «línea» o dentro de un cierto «continuo», de modo que se describe como «oscilando» entre los dos polos de la idealidad y de la realidad." (Ferrater Mora, 2004:1865-1866).

En las palabras concretas de Ferrater Mora, su afirmación es que el integracionismo no tiene por objeto definir absolutamente la «entidad», así que se vuelve una vez más a su reiteración inicial al establecer el concepto de integracionismo, que es el no situarse en cuestiones o situaciones absolutas, el integracionismo es anti-absolutista. Lo sigue 
reafirmando al concebir el integracionismo como un sistema que oscila entre los dos polos de la realidad.

Al no existir una realidad absoluta en el sistema integracionista no existe por lo tanto una realidad unilateral, por lo cual el método integracionista pretende ser transversal o multilateral. Continuando con el desarrollo analítico conceptual del integracionismo, se observa que el mencionado sistema no deja por fuera ningún paradigma aunque se consideren contrapuestos:

"En general, podemos decir que todo lo que es, es en tanto que oscila entre polos opuestos, los cuales designan sus límites, pero en modo alguno paradigmas de dos distintas formas de existencia. Ello supone que toda sucesión de formas de ser no constituye una serie de etapas determinadas o por un momento inicial absoluto que sería su base (ontológica o cronológica o ambas a un tiempo) o por un momento final absoluto (que sería su causa última o su paradigma metafísico), sino que constituye una línea ininterrumpida. Cada punto de esta línea está cruzado por dos direcciones opuestas; el olvido de una de ellas conduce a cualquiera de las concepciones filosóficas extremas antes mencionadas" (Ferrater Mora, 2004:1866).

Nuevamente Ferrater Mora hace gala de la amplitud de su sistema filosófico, el cual al no constituirse en un dogma, tiene la posibilidad de cruzar una línea en dos direcciones que estén opuestas o extremas. Su carácter transversal no niega la pertinencia de cada corriente filosófica, ya que no se descarta el aporte que otorga conceptualmente una visión del pensamiento perteneciente a otro sistema o concepción filosófica, sino que la asimila en conjunto con cualquier otra, incluso opuesta.

Mención adicional a las bases ontológicas o cronológicas de los paradigmas sujetos a un concepto inicial que pueda obedecer a un concepto absoluto, pero que al encontrarse bajo sometimiento del sistema integracionista se diluyen los absolutismos contenidos. El integracionismo no busca negar, sino superar o eludir hacia la búsqueda intermedia, como lo afirma Ferrater:

"El tipo de filosofía propuesto no consiste simplemente en negar las oposiciones para buscar un tercer término que las supere, o en eludirlas para buscar una posición intermedia equidistante. Rasgo característico del integracionismo es tratar de aunar los polos antedichos -y las concepciones correspondientes a ellos-mediante el paso constante del uno al otro. El integracionismo considera, en efecto, que ésta es la única posibilidad ofrecida a un pensamiento que pretenda efectivamente morder sobre lo real en vez de evitarlo o de inventar realidades supuestamente trascendentes sólo expresables por medio de otros tantos conceptos-límites" (Ferrater Mora, 2004: 1866). 
Desde esta perspectiva, el integracionismo se sitúa en el contexto conciliador, buscando posiciones intermedias, y como todas las vías medias en el pensamiento universal se coloca equidistante de todos los opuestos, ya que se postula como no dogmática, tampoco se constituye en una doctrina ni se considera a sí misma una corriente filosófica.

Hasta aquí se observa su pretensión metodológica, en oposición a una definición apegada a un referente específico, que se alimenta de corrientes, pero no a objeto de que esta alcance algún tipo de trascendencia.

La aplicación del método integracionista puede estar enmarcada en diversas teorías de pensamiento, Ferrater Mora las describe en cinco bloques y procede a caracterizarlas, de este modo se expone una a la vez:

"De las esferas a las cuales puede aplicarse el tipo de filosofía propuesto, elegimos cinco.

La primera perteneciente a la teoría de los universales. Algunos autores se manifiestan partidarios del nominalismo; otros, del realismo. A causa de los inconvenientes con que choca cada una de estas posiciones, muchos prefieren adoptar posiciones intermedias, tales el conceptualismo o el realismo moderado. Ahora bien, desde el punto de vista integracionista, nominalismo y realismo designan concepciones extremas, a la vez falsas e inevitables. En efecto, el nominalismo, llevado a un extremo, choca con la dificultad de que no puede propiamente decir nada acerca de la realidad, pues sus supuestos conceptos son sólo términos y los términos son sólo inscripciones físicas (y, por lo tanto, objetos reales sobre los cuales habría que enunciar algo). A su vez, el realismo, llevado a un extremo, choca con la dificultad de que dice ciertamente algo sobre el ser que es, pero nada más: su decir es, en el fondo, un callar. Una concepción aparentemente intermedia (como, por ejemplo, la del conceptualismo) se impone. Pero debe tenerse presente que esta concepción no es el resultado de eludir nominalismo y realismo: es simplemente el punto -siempre transitorio- de detención en el paso incesante que la mente se ve obligada a dar entre las concepciones extremas. En vista de que el nominalismo se anula a sí mismo, hay que retroceder a una posición realista; en vista de que el realismo se anula a sí mismo, hay que retroceder a una posición nominalista. Nominalismo y realismo quedan de este modo integrados, no eliminados o eludidos" (Ferrater Mora, 2004: 1866).

El integracionismo supone un grado de complejidad, ya que también se ocupa de los rasgos intermedios en las teorías de los universales. Incluso, aquellas que se consideran concepciones amplias o abiertas, tienen caracterización extrema cuando en sí niegan otra concepción como es el caso del nominalismo y el realismo, ya que ambas suponen algún 
tipo de delimitación o dogma que tiende a anularse a sí mismo, ya sea desde la perspectiva nominalista o realista.

Es aquí donde ocurre el sistema integracionista, al no eliminarse o descartarse ninguna de las teorías, ambas logran una fusión conjunta sin negar o hacer desaparecer alguna de las dos. Ninguna logra trascender a la otra.

Se atisba hasta ahora una visión cercana a la dialéctica hegeliana, haciendo la salvedad de que la síntesis constituye una superación de la tesis-antítesis y la premisa del integracionismo es la no superación de dos conceptos o corrientes opuestas, sino su integración. Una integración que no constituye una búsqueda definitiva sino transitoria.

Se observará en el próximo bloque la evolución del sistema integracionista en materia de metafísica, dentro de la cual Ferrater Mora destaca el concepto del ser:

"La segunda pertenece a la metafísica. El concepto de ser parece
ineludible si quiere designarse cualquier realidad, pues lo que por lo
pronto puede decirse de ella es que es. Sin embargo, algunos autores
prefieren definir la realidad por medio de otro concepto opuesto: el
de devenir. En el primer caso, el devenir es concebido como una
manifestación del ser; en el segundo, el ser es estimado como una
detención del devenir. Ahora bien, dadas las dificultades con que
choca en ambos casos la derivación de una instancia a partir de la
otra (si el ser es, ¿cómo puede decirse que deviene sin ponerle cuando
menos entre paréntesis el ser?; si la realidad consiste en devenir
¿cómo puede decirse que es si jamás es algo determinado, salvo el
pasar continuamente de un estado al otro?, etc.), puede buscarse un
supuesto principio que constituya el fundamento común del ser y del
devenir o colocarse en una posición intermedia. Lo primero exige un
incomprobable postulado metafísico. Lo segundo parece plausible,
pero siempre que se obtenga por medio de la afirmación sucesiva y
ulterior integración de los dos supuestos. Así, se declara que
cualquier entidad dada pertenece al polo del ser o del devenir según
su mayoro menor cercanía a uno o a otro. Pero, en rigor, pertenece a
ambos -o, si se quiere, es integrada, aunque en diferente grado, por
ambos" (Ferrater Mora, 2004: 1866).

Aunque la base metodológica no es distante de la expuesta en el primer bloque, Ferrater Mora hace referencia a postulados metafísicos e indagaciones del lenguaje respecto al devenir, a la manifestación y la detención del ser. Tomando en consideración que los postulados metafísicos son incomprobables, no tomarlos en cuenta sería su negación. Partiendo del postulado plausible del devenir, se busca un principio que sirva de fundamento. 
Encontrar la vía media coloca a prueba las concepciones opuestas, ya que la praxis integracionista considera las particularidades de las concepciones en diferentes grados pasando a un grado ulterior.

El integracionismo aborda la realidad de manera holística, sin pretensión de convertirse en una escuela que propulsa la filosofía como búsqueda de verdad última, incluyendo sistemas y corrientes que siguen su curso en la historia de la filosofía y el pensamiento.

El tercer bloque corresponde a la teoría del conocimiento, de la cual Ferrater Mora hace la comparación de los conceptos opuestos, la realidad fenoménica y la nouménica:

"La tercera pertenece a la teoría del conocimiento. Según algunos, la realidad es sólo fenoménica. Según otros, es exclusivamente nouménica. Los primeros reducen el mundo a un haz de cualidades; con el fin de predicar algo de ellas hay que decir de ellas algo universal - o conformarse con una infinita predicación-; por lo tanto, hay que suponer algo que no es meramente fenoménico. Los segundos reducen el mundo a un "en sí», de él no puede decirse sino que es en sí; con el fin de predicar algo más hay que suponer que posee algunas propiedades; por lo tanto, admitir que hay en él algo que no es meramente nouménico. El conocer efectivo sigue esta doble y contrapuesta vía: pasa de uno a otro extremo y en el curso de este pasar los integra, sin por ello tener que declarar que uno u otro son absolutamente verdaderos" (Ferrater Mora, 2004: 1866-1867).

Para José Ferrater Mora, no existe una realidad fenoménica ni nouménica, ya que el integracionismo no se caracteriza por ser reduccionista como en efecto ocurre con ambos bandos opuestos de la teoría del conocimiento.

Pero tampoco se puede establecer que sea un sistema ambivalente, ni constituye una corriente sintetizadora o de carácter trascendental. No hay absolutos verdaderos y efectivamente ambas posturas al encontrarse dejan de ser extremas.

En el cuarto bloque, se observa el mecanicismo y el vitalismo. Ferrater Mora arremete contra los purismos:

"La cuarta pertenece a la filosofía de la naturaleza orgánica. Hay en ella, entre otras, dos concepciones opuestas: el mecanicismo y el vitalismo. La disputa entre ambas concepciones parece interminable. Pero es que cada una de ellas olvida que su validez depende de la dirección que se subraye (hacia lo mecánico; hacia lo vital) al examinar la realidad correspondiente. Pues, de hecho, no hay realidad puramente mecánica ni realidad puramente orgánica: cada realidad es definible por integración de ambos polos, y cada uno de estos polos se hace más o menos presente en tanto que dirección 
según la «situación» de la realidad o del conjunto de fenómenos de que se trate dentro de la "escala ontológica»" (Ferrater Mora, 2004: 1867).

Hay una clave de comparación filosófica en la concepción ferrateriana integracionista y es la presencia constante de ambos polos al intentar definir la realidad. Una presencia impregnada de la escala ontológica.

Desde aquí se desprende que el integracionismo tiene su propia ontología y que busca los principios ontológicos de cada corriente o concepción filosófica que puedan estar en oposición. Pero al no constituirse en síntesis de ambas, no las descarta, no las reafirma, no toma partido por ninguna, ni busca el detrimento de una y la aprobación de la otra.

Para los fines consiguientes, Ferrater aborda el quinto bloque clasificado como filosofía del lenguaje. El análisis contrapone lo pragmático de lo sintáctico:

"La quinta pertenece a la filosofía del lenguaje. Se puede estudiar
éste desde el punto de vista de la ejecución de actos lingüísticos, cuya
codificación muestra la estructura del lenguaje. Se puede estudiar el
lenguaje asimismo como una estructura en virtud de cuyas reglas un
determinado acto cuenta como acto lingüístico. La adopción del
primer punto de vista hace hincapié en la dimensión pragmática del
lenguaje, pero es deficiente en la dimensión sintáctica y en porciones
importantes de la dimensión semántica. La adopción del segundo
punto de vista puede proporcionar sólidos fundamentos sintácticos y,
con todas las modificaciones pertinentes, bases semánticas, pero
corre el peligro de dejar sin explicar muchos fenómenos que tienen
lugar en la dimensión pragmática. El lenguaje como ejecución -o
como función-y como estructura son dos modelos que operan como
ideas-límites, cada una de las cuales puede entrecruzarse e
integrarse, o complementarse, con la opuesta" (Ferrater Mora, 2004:
1867).

Nuevamente es expresado el carácter conciliador del sistema integracionista, ya que considera aspectos del lenguaje que las corrientes de orden lingüístico desde la ejecución, función y estructura operan con límites y esa delimitación desde el sistema integracionista no impide su complementación.

Pero el asunto primario del integracionismo no es constituirse en un árbitro de los debates y las corrientes filosóficas. Y como se observa en el presente análisis no es un bosquejo de síntesis de sistemas opuestos.

Es evidente que un sistema-método como el integracionista genera oposición u objeción, por considerar la probabilidad de contradicciones en su aplicación al análisis de concepciones que algunos consideran irreconciliables. 
El propio José Ferrater Mora atiende esa posibilidad al expresar:

"Una objeción obvia a la concepción integracionista bosquejada es la de que la teoría que se adopte en cada caso, o el concepto que en cada caso se subraye, con el fin de ligar mediante una especie de incesante dialéctica los «límites», puede llegar a ser una teoría vacía a menos de adoptar la arriesgada hipótesis de una síntesis de contrarios. Además de poder terminar en un eclecticismo, el integracionismo puede convertirse en una concepción muy general que no logre engranar con ninguna realidad" (Ferrater Mora, 2004: 1867).

Parece que el integracionismo no define una postura arriesgada, o más bien corre el riesgo de ser una filosofía ecléctica, de características generalizadas que no engranan en una totalidad, una teoría de cualidad vacía.

No obstante, Ferrater Mora aclara que el integracionismo constituye un sistema filosófico de vanguardia, pero no definido en corriente de postulados absolutistas:

"Tanto para evitar estos peligros como por su propio desarrollo, el integracionismo se ha manifestado en una más avanzada etapa de un modo distinto. Ha conservado su intención metodológica y ha acentuado inclusive el interés por el análisis de ciertos conceptos con el fin de mostrar que, en casos básicos, dos conceptos dados pueden contraponerse y, a la vez, complementarse. Ello ocurre cuando, tomando cada uno de estos conceptos como concepto-límite, se explotan todas sus posibilidades, es decir, se extiende al máximo su aplicabilidad. En modo alguno un concepto se transforma en su contrario, pero el procedimiento adoptado es como una maniobra que permite seguir dos direcciones que, al contraponerse, se entrecruzan. Ahora bien, ello tiene lugar dentro de un esquema conceptual ontológico, es decir, de una teoría filosófica. El propósito de ésta es mantener líneas de comunicación tanto entre tipos de realidades como entre teorías posibles sobre estas realidades. Un supuesto básico de la teoría es que las realidades forman un continuo. Ello parece difícil de admitir, puesto que las realidades de que se trata son de muy distinta índole: entidades y procesos físicos, orgánicos y mentales, acciones humanas, instituciones, sistemas de reglas, códigos morales, teorías, etc”. (Ferrater Mora, 2004: 1867).

Sin embargo para profundizar más a este respecto Ferrater Mora advierte:

"El continuo de que se trata no es, sin embargo, un continuo lineal; los distintos tipos de realidades se hallan entreveradas y no encadenadas. No hay por ello ningún tipo de realidad al cual se reduzcan todas las otras, si bien ninguna realidad se halla completamente desvinculada de un contexto material. Ello hace posible hablar de un materialismo, aunque no de un monismo, ontológico. Las realidades forman grupos ontológicos (Véase) y tienen rasgos estructurales, pero no propiedades, comunes; a ellas nos hemos referido en los artículos sobre las nociones de Haberes, 
Presencia, Confluencia e In-trascendencia" (Ferrater Mora, 2004: 1867).

La premisa básica del integracionismo es en palabras de José Ferrater Mora " $e l$ análisis de ciertos conceptos con el fin de mostrar que, en casos básicos, dos conceptos dados pueden contraponerse y, a la vez, complementarse" (Ferrater Mora, 2004: 1867). Aquí no hay una concepción ecléctica. No hay una síntesis ni trascendencia de conceptos. Complementación es la palabra clave.

Por esa razón, José Ferrater Mora mantiene el postulado de que el integracionismo tiene finalidad o intención metodológica, pero además su propia realidad y por consiguiente su propia estructura ontológica no reduccionista.

Y el carácter de esta afirmación sobre la ontología integracionista se verá analizado en la lectura pertinente plasmada en una entrevista de la revista Teorema a José Ferrater Mora de El ser y la muerte. Bosquejo de una filosofía integracionista.

“T.: En el prólogo a El ser y el sentido hablas de una «tetralogía» filosófica en la que, te propones «concentrar... lo más granado de mi producción filosófica». La primera parte de esta tetralogía lleva por título El ser y la muerte. Bosquejo de una filosofía integracionista. ¿Qué es, y en qué consiste, la filosofía integracionista?

F.: Ante todo, pido disculpas por hablar de «tetralogías filosóficas» y de cosas como «lo más granado de mi producción filosófica». Lo que quería simplemente decir era que había cuatro temas, a cada uno de los cuales deseaba dedicar un libro. Es cierto que usé al efecto el nombre de «filosofía integracionista» y que los libros en cuestión, junto con otras obras (o partes de otras obras) corresponden a un punto de vista filosófico que puede seguir llamándose «integracionista». Sin embargo, soy ahora mucho, más escéptico tanto con respecto al nombre como, con respecto a la cosa. Me extiendo sobre el asunto en un libro que estoy ahora escribiendo con el título de Cambio de marcha en la filosofía, y en el cual trato de poner en claro en qué consistió mi primera conjetura «integracionista» y cómo ésta se fue modificando, hasta llegar al estado actual, donde el integracionismo de referencia no debe ser entendido como un esfuerzo de combinar o superar tendencias filosóficas, sino como un método, o conjunto de métodos, que hacen uso de cierta trama conceptual donde desempeñan un papel capital los que llamo «conceptos límites»." (Teorema, 1972: 97-108).

El integracionismo es un método para hacer filosofía y constituye a su vez una filosofía una forma de pensar que se arriesga a tender puentes y manejar posiciones encontradas, sistemas en apariencia adversos. Una forma de pensar y razonar que no objeta 
que hay maneras y métodos que pueden usarse para lograr un objetivo, dar vida a las ideas y que ellas sean trascendentales en la posteridad.

11.2. La delimitación ontológica de lo real y la ontología de la doble dirección.

Carlos Nieto Blanco en las líneas introductorias de su obra La filosofía en la encrucijada: Perfiles del pensamiento de José Ferrater Mora, reseña "un mensaje filosófico propio de nuestro tiempo" (1985: 16) ello en referencia incuestionable a la síntesis del legado de intelectual catalán, para luego añadir en el mismo orden de ideas: "obra de múltiples perfiles" (1985: 9), entre los cuales Carlos Nieto Blanco distingue el perfil ontológico; dicho decantamiento resulta apropiado ante el análisis más sucinto de la obra ferrateriana, puesto el papel permanente que tomó la ontología a lo largo y ancho de toda su línea escritural.

De hecho, tal como se profundizará en páginas venideras, el intelectual catalán se concentró, primordialmente, en aspectos de carácter ontológico. Llamando a su posición ontológica "monismo sui generis" puesto que hace una unificación entre el 'monismo' y el 'pluralismo', que mediante el 'emergentismo' permiten que se auto-ensamblen los elementos en virtud de sus propiedades o funciones, o lo que también define como la dualidad 'propiedades-funciones'.

Quedará establecido que cada estructura, aunque depende para existir de los elementos que la componen, no es reductible a ellos porque adquiere nuevas propiedadesfunciones que no se pueden explicar en función de las del elemento. La estructura se torna a la vez en elemento para una nueva estructura. El auto-ensamblaje comienza desde el nivel físico hasta el punto en que las estructuras adquieren propiedades-funciones más complejas y de un orden diferente como para dar lugar a un nuevo nivel biológico y así permitir que avance el continuo trascendiendo al nivel social para transversalizar lo cultural. Dado que es un continuo irrompible y oscilante entre la materia a la razón. A fin de entender mejor la posición del intelectual catalán con relación a la mencionada cuestión, se incorporará a continuación, la trascripción del artículo correspondiente a la noción de "Real y/o realidad", extraída del Diccionario de filosofía:

'REAL, REALIDAD. Se pueden considerar las expresiones 'es real' $y$ 'realidad' desde varios puntos de vista: 1) Decir de x que es real o decir que $x$ es una realidad no es, en rigor, decir nada de $x$. $x$ puede 
ser azul, redondo (o aproximadamente redondo), duro, etcétera, pero no tiene sentido decir que es real (o no real); $x$, sin embargo, es cuantificable, de modo que puede decirse que hay o no hay un $x$ tal que tiene tal o cual propiedad. 2) Decir de x que es real se entiende sólo en relación con expresiones como 'autentico', 'genuino', 'verdadero', 'natural', etc. (como cuando se dice que una manzana es natural; esto quiere decir que es real, pero en el sentido de que no está hecha de cera o no es una imagen holográfica). 3) Decir de x que es real es decir que no es meramente aparente, o ilusorio, o que no es «sólo posible». 4) Decir de x que es real o decir que es una realidad equivale a decir que existe, o es «actual»; la llamada «realidad» es en este caso lo mismo que la existencia (Véase)." (Ferrater Mora, 2004: 3014).

Lo primero que advierte José Ferrater Mora sobre las expresiones real o realidad, es el hecho de tratarse de dos términos muy similares y cargados de una pluralidad de acepciones que van desde lo existente, a lo posible, o desde lo verdadero o autentico, hasta que es cuantificable, significando de este modo que es una realidad, pasada la presentación de estas vastas posibilidades de lo real o de la realidad José Ferrater Mora pasa a las caracterizaciones de cada caso:

“... 1) y 2) son modos como pueden entenderse 'es real' e inclusive 'realidad', sin por ello suponer que hay un predicado especial (y en alguna manera «más importante» que otros) que se titula «real», o que hay algo, sea lo que fuere, a lo que cabe llamar «la realidad». Es posible reinterpretar 'es real' y 'realidad' en cualquiera de los dos modos indicados. Esto quiere decir que no es estrictamente necesario admitir, pero tampoco proscribir, estas expresiones..." (Ferrater Mora, 2004: 3014-3015).

Profundizando en cada acepción en este caso se brinda atención a la primera y la segunda afirmando José Ferrater Mora que ambas ofrecen equivalentes posibilidades de comprensión: "modos como pueden entenderse", es la expresión que emplea para dar apertura a sus explicaciones, en aras de diferenciar tales modos, presentes en las expresiones real y realidad, ambas enraizadas a la ontología, materia ampliamente trabajada por el autor de El ser y la muerte:

“...Clásicamente, sin embargo, 'es real' y 'realidad' se han venido entendiendo en los modos 3) y 4), considerándose el primero como un enfoque «negativo» (bien que necesario) y el segundo como un enfoque «positivo».

3) y 4) han sido empleados por muchos filósofos. La mayor parte de éstos ha considerado que el «problema de la realidad»-la cuestión de lo que es, propiamente, «la realidad»-es un problema metafísico (u ontológico). Ello ha llevado a examinar la noción de realidad en estrecha relación con nociones como la de esencia (Véase) y de existencia (Véase). Algunos han supuesto que sólo la esencia es real, 
otros han proclamado que la realidad corresponde únicamente a la existencia. Otros, finalmente, han señalado que solamente una Esencia que implicara su propia existencia es verdaderamente real y que todos los demás entes son formas menos plenas (o más imperfectas) de realidad. Esta última concepción -sobre la que nos hemos extendido en el artículo sobre el argumento ontológico (Véase Ontológica [Prueba]) - equipara la idea de realidad con la de perfección (o, más exactamente, con la de perfección infinita). En todos estos casos la idea acerca de lo que es real ha dependido de previos supuestos metafísicos (u ontológicos) y ha tendido además a equiparar la realidad (o «realidad verdadera») con lo que trasciende necesariamente a la experiencia... (Ferrater Mora, 2004: 3015).

La consideración al devenir de la tradición filosófica "-estén o no en concordancia con las posturas ferraterianas sobre el tema- que se evidencia en las líneas anteriores, es muestra del hondo respeto tanto por el saber filosófico en general, como por la rigurosidad propia del academicismo en que se ha hallado imbuido durante décadas, se recuerda al mismo tiempo que es el autor de decenas de obras sobre tales cuestiones, desde las que ha venido desarrollando cada uno de estos tópicos:

"Ciertos filósofos, en cambio, han hecho constar que sólo en relación con la experiencia podemos adquirir una idea justa acerca de lo que es la realidad. Lo real es dado, como sugiere Kant, en el marco e la experiencia posible y por eso «lo que concuerda con las condiciones materiales de la experiencia (de la sensación) es real». En cuanto noción, la realidad puede convertirse en una de las categorías o conceptos puros del entendimiento: «El postulado para el conocimiento de la realidad de las cosas - escribe a este respecto Kant- exige una percepción; por consiguiente, una sensación acompañada de conciencia del objeto mismo cuya existencia ha de conocerse, pero es preciso también que este objeto concuerde con alguna percepción real según las analogías de la experiencia, las que manifiestan todo enlace real en la experiencia posible.»" (Ferrater Mora, 2004: 3015)

Como ya se realizó advertencia los otros también tienen cabida en el ejercicio reflexivo realizado por Ferrater Mora, amplió panorama desde el cual va dando forma y consistencia a su tejido de ideas o posturas que le permitan el fin último e inicial de toda investigación: la generación de saber. En José Ferrater Mora se hace visible la tesis de que el reconocimiento del otro cumple la tarea del autorreconocimiento:

“...Como la noción de experiencia no es siempre suficientemente clara y, además resulta a veces difícil distinguir entre la realidad en tanto que dada y la realidad en cuanto «puesta» (o categoría de la realidad), se han propuesto otras concepciones del ser real. Una de ellas hace de lo real algo que se presenta o puede presentarse a una conciencia. Otra muy difundida es la que equipara realidad a «objeto» (en el sentido amplio de este término, como aquello de que 
puede enunciarse algo). Todas estas concepciones eluden la dificultad que ofrecen las nociones referidas en el párrafo anterior, pero les es común a éstas el no poder distinguir entre las especies o formas de lo real. Con el fin de salvar este último obstáculo pueden adoptarse varias actitudes..." (Ferrater Mora, 2004: 3015).

Con énfasis en la ambigüedad o imprecisión de alguna que otra noción, la comparatividad facilita el autorreconocimiento y permite superar las barreras que hay en las dificultades que ofrecen las nociones distintas. Hasta llegar a las opciones que se muestran en lo inmediato:

“...de las que mencionaremos las siguientes: Una consiste en declarar que el ser real es lo que es común -sea lo que fuere- a todas las especies de realidad que pueden describirse y en proceder a clasificar estas especies. Tenemos entonces la realidad articulada en realidad subjetiva, objetiva experimentable, ideal, etc. Ello equivale substancialmente a erigir una teoría de los objetos y en encontrar por inducción lo que es común a éstos en tanto que objetos." (Ferrater Mora, 2004: 3015).

Se ubica así una concepción iniciática, consistente en una declaración de lo real como aquello sinónimo de común. Concepción generadora de una realidad adjetivada por distintas y muy amplias adjetivaciones, en la que tal acto tiene una equivalencia en el levantamiento de una necesaria teoría que se ocupe de atender a los objetos:

“... Otra se basa en la idea de que el concepto de realidad no es unívoco y de que hay, además, una serie de entidades que van de lo menos real a lo más real. Usualmente hay que agregar a esta concepción una metafísica que comience por adscribir realidad máxima a ciertas entidades. Éstas pueden ser lo material, lo personal, lo temporal, lo trascendente, lo espiritual, etc..." (Ferrater Mora, 2004: 3015).

Es la ocasión para una concepción secundaria, la cual plantea un concepto de realidad que no se presenta como univoco, poseedor asimismo de las posibilidades de entidades graduales; es decir, ofreciendo graduaciones entre lo más real hasta lo menos real y viceversa, lo que otorga las posibilidades de precisión contando en lo sucesivo con graduaciones específicas de la realidad:

“...Otra se funda en una fenomenología de la realidad (una fenomenología ontológica u ontología fenomenológica). Es lo que ha intentado hacer Nicolai Hartmann en el libro mencionado en la bibliografía. Según este autor, la realidad es una de las maneras primarias del ser. Así, es necesario ante todo distinguir esta forma de todas las que se adhieren equívocamente a ella. Hartmann distingue de este modo varios conceptos de lo real, que somete a crítica: 1) Lo real como opuesto a lo aparente. Esta significación no puede ser admitida, pues lo aparente es también real, ya que de otra forma «no sería una apariencia» (op. cit., pág. 54). 2) La realidad como 
actualidad (Wirklichkeit) puede equipararse a la realidad como existencia (Realität)." (Ferrater Mora, 2004: 3015).

Introduce Ferrater Mora a un autor clave para poder comprender en su justa medida el tema en cuestión, aunque en las próximas líneas el filósofo catalán guarde distancia en aspectos fundamentales expresados por el filósofo alemán. Se trata de Nicolai Hartmann, nombre clave si se pretende profundizar en las ideas anunciadas o discutidas por José Ferrater Mora, como se verá claramente:

“...Tal equiparación es doblemente errónea, pues lo real (Reale) posee en sí también los otros modos -posibilidad real, imposibilidad real, etc.-; además, podemos concebir una «realidad esencial o ideal» no menos que una «realidad lógica o cognoscitiva». La mencionada equiparación es un ejemplo de confusión de la esfera del ser con el modo de ser. 3) La realidad como actualidad puede equipararse con la efectividad (Tatsächlichkeit). Ahora bien, esta última es sólo «actualidad real»y excluye por principio las demás esferas. 4) La realidad como actualidad puede equipararse con la existencia. Se trata de una confusión difícil de desentrañar pues, como dice Hartmann, «el ser real es lo más esencial en la existencia». Ahora bien, esto representa una confusión del modo del ser con el momento del ser. Los modos del ser son del tipo de lo real y de lo ideal. Los momentos del ser son del tipo de la esencia y de la existencia. Y la esencia reclama asimismo el ser real." (Ferrater Mora, 2004: 3015-3016).

Ya se había advertido sobre la ubicación de diversos puntos de divergencia, donde se presentan los elementos yuxtapuestos entre las dos visiones escasamente conciliadas de ambos autores. José Ferrater Mora señala y argumenta acertadamente cada uno de los qué y por qué de las posiciones asumidas desde su experiencia investigativa y su ejercitar meditativo:

“...5) Lo real puede equipararse con lo activo o efectivo. Mas esto representaría convertir un modo de ser en una determinación suya. 6) Lo real puede ser definido como algo que designa la mayor o menor plenitud del ser (el organismo como algo más «real» que lo inorgánico, etc.). Tal concepto de realidad se aproxima al sustentado por los escolásticos, ya que hace depender la realidad de un ser de la suma de sus predicados positivos. Se confundiría en tal caso la Wirklichkeit con la realitas. En otros términos, habría confusión del modo con la determinabilidad. Pero mientras la determinabilidad varía, el modo permanece, según Hartmann, a través de todas sus posibles determinaciones. En el modo como tal no hay gradaciones. 7) Puede equipararse y confundirse la realidad con la actualitas en tanto que acto de ser. Más esto significa sólo la realización de un eidos o essentia. No afecta a lo modal y presupone un esquema

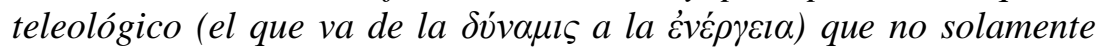
no es aplicable a todo lo real, sino que excluye lo imperfecto. 8) Puede confundirse realidad con «posibilidad de percepción de algo» 
y aún con «el hecho de que algo se dé a los sentidos» (como ocurre con el segundo postulado del pensamiento empírico en Kant)..." (Ferrater Mora, 2004: 3016).

Se distingue entonces entre polaridades como "activo" o "afectivo"; "mayor o menor plenitud del ser", en donde son reconocidas las proximidades con las teorías escolásticas; entre otras conjugaciones que confluyen en una determinabilidad variante acompañada de un modo caracterizado por la estabilidad. Obteniéndose así un eidos o

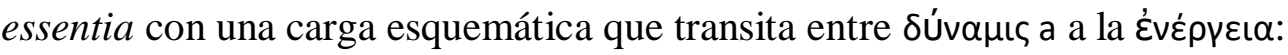

“...En este caso se hace de la realidad no una manera de ser, sino de conocer. Por este motivo una ontología crítico-descriptiva debe establecer claras distinciones entre los distintos conceptos de lo real: realidad lógica, realidad cognoscitiva, realidad esencial, etc., evitando aplicar a una forma de realidad categorías que correspondan exclusivamente a otra. La realidad como existencia puede ser, desde este punto de vista, uno de los momentos del ser, la realidad como algo distinto (u opuesto) a la idealidad, una de las formas del ser, la realidad como actualidad, uno de los modos del ser...” (Ferrater Mora, 2004: 3016)

La tercera y penúltima postura se ubica fortalecida por la presencia de la herencia filosófica alemana en manos de Immanuel Kant, tratase de una realidad como modo de conocer, dando pie desde las especificaciones de la ontología crítico-descriptiva de diferentes conceptos con sus correspondientes distinciones.

El siguiente párrafo inicia la exposición desplegada por Ferrater Mora sobre la cuarta y última postura o actitud integrante de este conjunto de ideas sobre las nociones de 'real' y 'realidad', anunciadas al principio las cuales continuaran en las próximas páginas de este y otros capítulos y subcapítulos en un necesario dialogo integracionista muy propio del estilo de redacción y exposición ferrateriano:

“...Otra actitud consiste en poner de relieve ciertas notas que posee lo real como real (notas, por tanto, que constituyen todo lo que es en cuanto que es real). Aunque esta actitud tiene algunas analogías con la anteriormente reseñada, difiere de ella en que se apoya en una descripción metafísica de lo real, o, si se quiere, en una descripción de lo real como objeto de una «filosofía primera». Mencionaremos dos ejemplos. Para Xavier Zubiri, las dimensiones de la cosa como cosa real son «la riqueza», «la solidez»y el «estar siendo». Se trata de «tres dimensiones estructurales» por las cuales se miden diferencias de realidad, esto es, el grado de realidad. Estas dimensiones se implican mutuamente, de modo que deben ser tomadas «a una», como «unidad estructural de la realidad simpliciter de algo: su constitución física individual». Para Laín Entralgo, los caracteres o notas de la realidad son el ser «ineludible», «resistente», «asombroso», «inteligible»y «poseíble»... “ (Ferrater Mora, 2004: 3016) 
Se añade a las posibilidades de acción, otra consistente en colocar en evidencia las notas que conforman aquello ciertamente real, posición de algún modo analógicamente emparentada con las anteriores posturas o actitudes; se subrayan así las características de lo real enunciadas por el filósofo español Laín Entralgo en contraste con las dimensiones posicionadas por el célebre pensador Xavier Zubiri:

“...Todos los análisis anteriores del concepto de realidad tienen un rasgo común: el de admitir que la expresión 'es real' es una expresión significativa. Los empiristas lógicos y muchos neorrealistas niegan este supuesto. A su entender, no puede enunciarse con sentido si ciertas entidades (como la materia, el yo, etcétera) son o no reales. Por lo tanto, el problema del concepto de realidad es para ellos un pseudo-problema; 'realidad' es un término que no debe ser hipostasiado en una entidad. En muchos casos los autores citados entienden 'es real' como equivalente a 'existe', y 'existe' como equivalente a 'está cuantificado' (lógicamente hablando)..”. (Ferrater Mora, 2004: 3016).

Obligado paréntesis donde José Ferrater Mora se detiene para realizar una necesaria puntualización retrospectiva, recordando el insistente rasgo entre cada una de la expresiones analizadas que han girado laboriosamente con diversidad de meditaciones sobre lo real y la realidad, donde todas ellas asumen cuasi al unísono el valor significativo de dicha expresión. Aunque asimismo recuerda aquí el intelectual catalán, los planteamientos de algunos empiristas lógicos y cierta cantidad importante de neorrealistas, dedicados a la negación del anunciado supuesto, pues según estos dos grupos no es posible la enunciación de ciertas entidades en aras de determinar su cualidad de real o no real:

“...Esta concepción tiene según otros autores, dos inconvenientes. El primero es que dentro de ella resulta imposible dilucidar si hay o no distintas formas de realidad. El segundo es que en ella no son admisibles expresiones tales como 'el hombre está volcado a la realidad', 'el hombre está implantado en la realidad', etc., que según algunos pensadores (por ejemplo, Zubiri) permiten entender la estructura de la vida humana $y$, con ella, la estructura del conocimiento (objetivo). Es difícil, pues, que el problema de la realidad pueda ser descartado de la filosofía. Algunos creen, por el contrario, que este problema es el problema filosófico por excelencia. Ahora bien, se trata de un problema que no puede dilucidarse aisladamente..." (Ferrater Mora, 2004: 3016).

De acuerdo al problema filosófico planteado y destacando algunas de estas consideraciones señaladas por Ferrater Mora en relación a Zubiri, se manifiesta la imposibilidad para establecer diferencias entre desiguales formas de realidad que incluyen estructuras de conocimiento, así como también la negación que da cabida a algunas de estas expresiones que son fundamentales para la comprensión de las estructuraciones 
inherentes a la vida humana, las cuales acompañan una estructura objetiva del conocimiento. Se especifica así la dificultad existente en descartar el problema de la realidad del fragor filosófico, indicando que según algunas creencias en muchas ocasiones representan el principal problema de filosofía:

“...Esto explica que en todas las ocasiones en que ha sido planteado se haya recurrido a otros conceptos para perfilarlo. Nos hemos referido ya a algunos de ellos: posibilidad, actualidad, existencia, esencia, efectividad, ser. Se trata de conceptos ontológicos (por lo menos en un sentido amplio de este adjetivo); no es extraño por ello que la ontología haya sido definida a veces como la ciencia de la realidad qua realidad" (Ferrater Mora, 2004: 3017).

Encuentra en estos espacios José Ferrater Mora la explicación al problema planteado desde el inicio en cuanto a la aparentemente imposible capacidad de aprehensión o estabilización conceptual de la noción de real o realidad, la cual al no conseguir una solidez que permita su firme posicionamiento transcurre entre uno y otro concepto que en la mayoría de los casos solamente consigue aproximarse levemente a el anhelo establecido en un principio:

"Uno de los problemas más importantes que se plantean acerca de la realidad (sea ésta la que fuere) es el de los modos de expresión de la misma. Este problema suele ser conocido con el nombre de «Realidad y lenguaje». Se trata de saber cómo es posible hablar acerca de lo real y cuáles son los marcos lingüísticos más apropiados para este propósito. Una dilucidación del problema del lenguaje (Véase) es necesaria antes de poder darse un respuesta a la cuestión de referencia. Ligado a este problema se halla el conocido con el nombre de «Lógica y realidad», sobre el cual nos hemos extendido en el artículo correspondiente." (Ferrater Mora, 2004: 3017).

Los modos de expresión de lo real o de la realidad, forman parte de los problemas de mayor significancia integrantes de tal problemática. Los mismos han sido atendidos por diferentes especialistas, en múltiples áreas del saber, agrupados frecuentemente bajo el rótulo de "Realidad y lenguaje", espacios donde se les otorga un abordaje inscrito dentro de la ciencia encargada de atender el lenguaje, al que se le anexan consideraciones de rigor filosófico, bajo el título de "Lógica y realidad", complementándose cada una de estas etiquetas desde su campo de acción y objeto de estudio específico, produciendo las consideraciones generales inscritas en la postura ontológica elaborada por José Ferrater Mora:

"Otro problema importante es el del conocimiento (posibilidades y límites de la aprehensión de lo real). Hemos tratado este punto y hemos presentado las diversas subcuestiones implicadas y las varias 
respuestas propuestas hasta ahora en el artículo sobre la noción de conocimiento (Véase)" (Ferrater Mora, 2004: 3017).

Concluye con estas líneas José Ferrater Mora, recalcando como problema, aunque de similar grado de importancia "el del conocimiento", pues este es la representación de las verdaderas posibilidades de éxito en la captación de la realidad. Profundización realizada en otro apartado del Diccionario de filosofía, aquí el académico catalán ofrece además la posibilidad reiterada de su familiar autorreferencialidad. Ha develado las conexiones que dan pie a una delimitación ontológica de lo real y erigen las posibilidades justamente reales de precisar una ontología de la doble dirección.

\subsection{Una lectura a El ser y la muerte. Bosquejo de filosofía integracionista.}

Ya el análisis acerca del Integracionismo, a través del concepto expresado por José Ferrater Mora en su Diccionario de filosofía, ha permitido identificar que el desarrollo del mismo sigue siendo sucinto, ya que reduce o es síntesis de un sistema filosófico que además constituye, de acuerdo al propio José Ferrater Mora, un método en sí mismo.

Ese método que compone su obra, de acuerdo al prefacio que José Ferrater Mora hace para su libro El ser y la muerte. Bosquejo de filosofía integracionista (1979) comenzó por 1947 con la obra El sentido de la muerte. En efecto, en este libro expresa abiertamente la perspectiva de la tanatología ferrateriana, que se puede remontar incluso a años anteriores.

En el año 1946, aparece publicado el libro La ironía, la muerte y la admiración, breve obra que recoge sus primeras indagaciones sobre uno de los temas que ulteriormente desarrollará con ímpetu, la muerte, pero la muerte como parte del ser, que representará la muerte como inductor de pensamientos y como combustible de la creación filosófica.

Parece evidente que la muerte en Ferrater Mora se alza como un elemento primordial, al que se le identifica como hilo conductor entre su obra temprana hasta su obra más tardía, pero que no por ello mantendrá en el tiempo una visión lineal.

La reescritura y revisión constante de sus pensamientos plasmados en sus obras escritas demuestran que se está ante la presencia de un filósofo que no es estático, en todo caso se mostrará tan dinámico como la vida misma. Eso sugiere que la filosofía 
integracionista puede pasar por diferentes momentos sin convertirse en un método no perfectible, libre de ejercicios dogmáticos y de constante transformación.

José Ferrater Mora en el prefacio ya citado, hace una pertinente referencia a la reescritura de sus obras y afirma:

"A menos de ser una momia intelectual, o de ser un testarudo al extremo, es comprensible que un autor vaya cambiando sus opiniones. El cambio se debe en parte a que en el curso del tiempo el autor va adquiriendo normalmente mayor, y mejor, información sobre los temas que ha tratado. Se debe asimismo a que, al crecer en edad, puede ir creciendo en madurez de juicio. Se debe, finalmente a cambios de época: en distantes épocas se ven cosas distintas, o se ven las mismas cosas de distintos modos" (Ferrater Mora, 1979: 7).

Pero todo eso no descarta, en lo absoluto, que el tema de la muerte, como el del ser, no esté impregnado de filosofía existencial, ello por más que Ferrater Mora pareciera 'querer alejarse' de estar identificado o que se le asigne la etiqueta de existencial. En el mismo prefacio, el pensador señala con relación al tema de la muerte:

"Que el tema de la muerte, especialmente como muerte humana, ha experimentado diversas vicisitudes en el curso de la época moderna. Las ha experimentado asimismo en las últimas décadas. Durante un tiempo fue tratado casi exclusivamente por autores afines a tendencias de carácter «existencial»" (Ferrater Mora, 1979: 8).

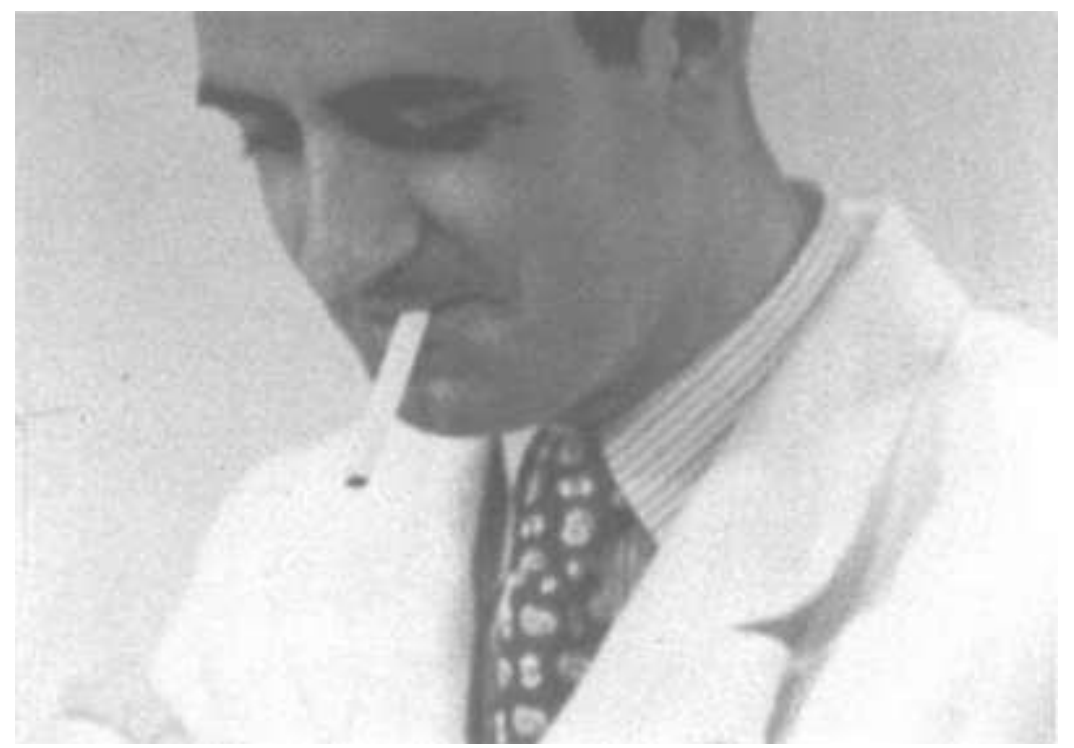

Ilustración 15: Reseña fotográfica en artículo: Variaciones de Ferrater Mora [Entrada en Blog] Lorem ipsum (dolor sit amet) (2007) Tomado de: http://condeduque.blogspot.com/2007_04_01_archive.html. 
Aunque el autor nunca se reconoce dentro de las tendencias de "carácter existencial", tampoco lo niega, representando así quizás algo típico de su método filosófico integracionista, que no niega, ni reafirma, sino que integra.

Lo que pudiera constituir un signo de distinción o distancia en torno al existencialismo en sí, es el aspecto que aborda en cuanto al tema de la muerte, en el mismo prefacio establece:

"He aludido oportunamente a ella en la presente edición, pero sin darle cabida excesiva, porque mi tema no es sólo el de la muerte humana, sino el de toda "cesación», y esto requiere un análisis filosófico de mayor alcance y generalidad" (Ferrater Mora, 1979: 8)

Es en este punto donde puede considerarse que el sistema integracionista parece que está en una situación distante del existencialismo, ya que para Ferrater Mora hay separación de la muerte humana y de la muerte del resto de las entidades no humanas como el resto de la vida orgánica. Pero esa distancia no es determinante si se considera que la cesación puede también constituir un elemento existencial desde la observación de la muerte humana. Este un tema también abordado en el Diccionario de filosofía, del cual hay un análisis en el presente trabajo de grado, particularmente en lo referido a la "cesación".

José Ferrater Mora en la sección introductoria de El ser y la muerte (1962) comienza esta obra no con el ser, sino precisamente con la muerte:

“Tan distintas son las «imágenes» que evoca la palabra 'muerte' que con frecuencia no parecen reflejar la misma realidad. La muerte es vista desde distintos modos según las culturas, las profesiones, las circunstancias personales y sociales. Es afrontada de modo distinto por el «primitivo» y por el «civilizado», por el hombre del agro y por el de la urbe, por el que vive en la estrechez y el que nada en la abundancia. Mientras el adolescente puede entreverla como liberación de un vago mal cósmico, el joven puede afrontarla como prenda de una acción heroica, o desesperada, y el hombre maduro puede divisarla asomando su rostro tras el tráfago cotidiano o en el trance de una enfermedad incurable" (Ferrater Mora, 1979: 9).

El comentario de Ferrater Mora respecto a la realidad diversa y puntos de vistas distintos en relación a la muerte no está tan distante de lo que consideran muchos filósofos existenciales, que también son diversos en sus postulados de acuerdo a la corriente filosófica con la que se identifican o se orientan. Y aunque José Ferrater Mora se propone en el resto del contenido de su libro a exponer el método integracionista, no puede dejar de lado que en sus postulados hay una influencia de discursos de filiación existencial, al situar 
en el pensar y el quehacer humano la relación intrínseca de su vida con respecto a la muerte partiendo desde el existir o lo existencial.

Y es desde la misma introducción, en la que José Ferrater Mora se plantea disertar sobre los enfoques existenciales, al exponer una serie de enunciados como problemas a las diversas formas de ver o percibir la muerte, de hecho incluso introduce una discusión de supuestos para complejizar el asunto:

"Para complicar las cosas, hablamos de 'muerte' y de 'morir' en varios contextos: 'Juan ha muerto', 'Hemos encontrado una ardilla muerta', 'El cubismo ha muerto', 'Se ha descubierto ahora que la Luna no es un astro completamente muerto'. En los dos últimos casos, podemos evitar el uso de 'muerto' diciendo por ejemplo, 'El cubismo ha pasado a la historia', 'Se ha descubierto que en la Luna tienen lugar procesos de carácter volcánico (u otros similares)' pero seguimos entendiendo lo que queremos decir por 'muerto'. Lo malo es que parece que queremos decir tantas cosas, que terminamos por concluir que sólo hay muy vagas similaridades en el uso de dichos términos" (Ferrater Mora, 1979: 9).

José Ferrater Mora es insistente en partir de un tema existencial y exponerlo en términos de indagaciones del lenguaje, de cómo se expresan las ideas a través de las palabras, de la interpretación de las realidades de acuerdo a su situación, de cómo se desarrollan en sus acontecimientos. Desde el lenguaje de pueden expresar ideas en diferentes modos queriendo decir lo mismo, aunque esa misma visión muy bien pudiera constituirse en una variable que permita ampliar el problema de qué es la muerte, que la muerte no es una sola cosa y que no es simplemente un término.

Ésta no es una discusión alejada en algún modo de los temas de carácter existencial que a su vez constituyen un conjunto de consideraciones que ya han tratado filósofos de tendencia existencial. Es así como el pensador catalán propone una discusión para trazar el camino:

"Propongo aquí, para empezar, que todas las «imágenes» de la muerte a que he aludido ante, se refieren a la misma realidad: el simple hecho de dejar de vivir. Presupongo asimismo que hay algo común entre la muerte de los seres humanos y la de otros organismos biológicos. Todos ellos dejan en algún momento de vivir. 'Dejar de vivir' significa a la vez «dejar de existir»o «cesar». En este caso, habrá que tener en cuenta otras realidades además de las orgánicas. Normalmente, se dice que todas las realidades, incluyendo las orgánicas y la humana, dejan de existir, o cesan, y que las realidades y la humana, además, dejan de vivir o mueren"." (Ferrater Mora, 1979: 9-10). 
Es interesante entrever que José Ferrater Mora se dispone a marcar una diferencia entre las consideraciones de las realidades, haciendo hincapié que las realidades no sólo corresponden a lo humano y orgánico. Hay cosas dentro de la realidad existencial que pueden considerarse no humanas y no orgánicas. En este contexto el pensador integracionista enuncia los elementos que van a ser considerados para luego profundizar sobre su metódica filosófica:

"Del subtítulo de esta obra se desprende que ésta aspira a desarrollar una posición que he llamado a veces «integracionismo». En esta posición se eliminan toda clase de «Absolutos», llámense «Naturaleza», «Conciencia», «Objeto», «Sujeto», etc. Los nombres de tales «Absolutos» son conservados en tanto que puedan expresar conceptos-límites. Mediante los términos que designan tales conceptos podría hablarse de semejantes «Absolutos» si los hubiera. No siendo admitidos, los conceptos-límites correspondientes lo son de «realidades-límites», que llamaré a menudo «polos» o «polaridades» y que no trataré como realidades. Es real sólo lo que es localizable entre polaridades, sin jamás congelarse en ninguna entidad «absoluta»" (Ferrater Mora, 1979: 15).

El pensador catalán es preciso al iniciar su "bosquejo de filosofía integracionista". Ya hemos visto que la filosofía integracionista no es una corriente de pensamiento que tributa o aspira a una verdad absoluta. No es sectaria ni dogmática, pero a la vez admite que para hacer un análisis filosófico los conceptos-límites, que a su vez pueden considerarse polos o polaridades, son necesarios.

Sin embargo, no considera que estos conceptos-límites o polos sean realidades y los delimita a su consideración primaria, dado que el concepto es una visión, no una realidad. En palabras del propio José Ferrater Mora "este libro trata de dar a cada cual lo que le pertenece" (Ferrater Mora, 1962), haciendo pertinente todo saber aunque ese saber pudiera ser sectario o dogmático, pero que en ningún modo deba ser excluido o apartado.

En este sentido, la filosofía integracionista no intenta superar o desplazar otras formas de pensamiento, puede alimentarse de ellas sin incurrir en una forma de sincretismo filosófico, entendiendo que el sincretismo es una manera de conciliar doctrinas encontradas o radicalmente adversas. En otras palabras, la filosofía integracionista no es una corriente de pensamiento fundada en asimilación o fusión para dar un carácter dual entre posiciones filosóficas diversas. Es un método de pensamiento que tiene sus propias acciones, que produce sus propios acontecimientos y que toma equidistancia de los absolutos. 
Ahora bien, de acuerdo a lo que José Ferrater Mora vislumbra o considera un bosquejo filosófico, que busca elaborar formas de pensamiento y asumir una posición ante el universo de corrientes filosóficas, que además pretende estar distante del conjunto de filosofías que tienen la tendencia a situarse en el espacio de las verdades absolutas, tampoco se sitúa en terreno del escepticismo y el agnosticismo. Esto lleva a situar el método integracionista a otra postura equidistante, no se ubica en temática nihilista de la no verdad o de negar alguna realidad sea humana, social, política o metafísica.

Hasta el momento se pudiera entrever que la filosofía integracionista no es absolutista, dogmática, sectaria, sin filiación al escepticismo filosófico, está lejos de ser nihilista, materialista, positivista, ninguna vertiente de sincretismo. No toma partido, no se adhiere a polos y conceptos-límites, pero sí los considera pertinentes. Reconoce que hay realidades y son diversas, que pueden evocarse desde distintos contextos.

Entonces, ¿Cuál es el horizonte estructural de la filosofía integracionista? José Ferrater Mora puntualiza aspectos que pueden ir mostrando un panorama, imágenes que sugieren su esencia:

"El punto de vista adoptado es, en cuanto a punto de vista, un método de conocimiento, pero uno que aspira a engranar con las estructuras de las realidades. La perspectiva aquí ofrecida es, pues, realista y no instrumentalista. Por eso es difícil, caso que sea posible, distinguir entre lo que en tal punto de vista es epistemológico y lo que es ontológico, entre lo que es método para comprender la realidad y lo que es hipótesis sobre la propia realidad. Las dos cosas marchan seguramente juntas: se abraza una determinada epistemología por corresponder a una ontología, y se abraza una determinada ontología por adecuarse a una determinada epistemología" (Ferrater Mora, 1979: 17).

Toda filosofía tiene su carácter y como tal su propia identidad, sus valores, su sustancia. La filosofía integracionista como método también reconoce que tiene identidad epistemológica y ontológica, sin enunciados que conlleven a una tautología, pero que tampoco se constituye en una dialéctica de orden hegeliano. No por esto, el integracionismo se encuentra lejos de estar influenciado por Hegel o las dialécticas que han nacido en la tradición filosófica anterior a Hegel. Ya que la dialéctica constituye una doble dirección, el integracionismo se alimenta de conceptos límites sin constituirse en una fórmula reduccionista, su búsqueda es el encuentro pero su meta no es la síntesis. Por ello, José Ferrater Mora sigue describiendo el carácter del método integracionista: 
"Toda realidad o tipo de realidad es definible por medio de una doble «tendencia»o, como se indica oportunamente (\$ 6), por medio de una «doble dirección». Se trata en suma de un «integracionismo nocional» a la vez de un «integracionismo real».

El uso de conceptos límites de índole «polar» no significa que el integracionismo propuesto sea una mera «filosofía de la polaridad», la cual corre a menudo el riesgo de convertirse en un eclecticismo inocuo. El integracionismo hace algo más que combinar más o menos automáticamente conceptos polares, o armonizar filosofías mutuamente hostiles. De hecho, no me importa gran cosa que una determinada tendencia filosófica pueda aparejarse o no con otra al parecer opuesta". " (Ferrater Mora, 1979: 17-18).

José Ferrater Mora consolida el carácter amplio de su sistema filosófico, sin considerarlo una corriente ecléctica, toma distancia de la dialéctica hegeliana ya que tampoco busca establecer una síntesis de la confrontación de una filosofía como tesis y otra como antítesis. Desde las perspectivas equidistantes que puedan estar contenidas en dos tendencias filosóficas opuestas no son de importancia a la hora de querer establecer un acercamiento, ya que busca integrar ideas, no unirlas o que una tendencia logre imponerse sobre otra, incluso si cada tendencia tiene su propia dialéctica o corresponde en todo caso a una tendencia filosófica absolutista. Sin embargo, el pensador catalán no descarta que el integracionismo tenga su propia dialéctica o una especie de "dialéctica de orientaciones", sin embargo advierte:

"Si el vocablo 'dialéctica' no hubiese sido mellado por el uso (y, sobre todo, por el abuso), no tendría inconveniente en adoptarlo para caracterizar, cuando menos en parte, el integracionismo. En efecto, la forma de pensar basada en la constante oscilación entre elementos contrapuestos, sin detenerse jamás en esta marcha, o doble marcha, incesante, es en parte de naturaleza dialéctica. Pero a diferencia de otras formas de pensamiento dialéctico, el que aquí propongo no pretende encerrar conceptualmente, y de una vez por todas, la realidad, sino justamente lo contrario: brindar un máximo de posibilidades para abrirse sin prejuicios a cualesquiera formas de realidad" (Ferrater Mora, 1979:20-21).

El integracionismo como método tiene elementos naturales contenidos en diversas filosofías, sus rasgos o lenguajes de expresión epistemológicos, una distintiva ontología y además una pertinente parte dialéctica. Y más allá de esos elementos o componentes, su carácter es libre de prejuicios, ya que no encierra la realidad dentro de un concepto, la realidad no es pura o impura, la realidad es tan sublime como sentida, sin la trampa de los enunciados doctrinarios o absolutistas. Para Ferrater Mora, la filosofía debe abrirse a la realidad, no postrarse a los prejuicios, siendo la realidad un tema importante en los temas 
de la filosofía existencial y que toda filosofía aunque tenga una tendencia polar siempre reflejará una realidad inherente a lo existencial.

Incluso, salvaguardando la opinión del filósofo sobre el abuso de los 'ismos' que muchas veces quieren significar todo y a veces no significan nada, igual son pertinentes dada su utilidad en el análisis de las realidades. Incluso se atreve a usar esa categoría para dar una especie de cierre a la caracterización de su método filosófico como a continuación se puede apreciar:

"He usado el término 'integracionismo'. Como casi todos los filósofos, desconfio de los «ismos»; dicen a la vez poco y demasiado. Pero no veo por qué no se puede usar un vocablo terminado en 'ismo' siempre que con ello no se crea estar al cabo de la calle. Aceptada esta cautela, los «ismos» no son excesivamente dañinos. Me decido, pues, a proponer todavía otro «ismo» para perfilar el integracionismo: el empirismo dialéctico. Sugiero con ello una forma de pensar que aspira a ser fiel tanto a la lógica de los conceptos como a la estructura de la realidad". (Ferrater Mora, 1979: 20).

Decir 'empirismo dialéctico' no constituye en sí una corriente filosófica, sino una forma de hacer filosofía, hacer filosofía comparando realidades de orden existencial, realidades que están contenidas en temas relacionados a la materia, a las estructuras de la razón. En lo existencial hay lógica y realidad. Concluyendo que el 'integracionismo' es una metódica, una forma de analizar y hacer lecturas de tópicos, que hace contraste de posiciones, acercamiento de diversas consideraciones, ese método también puede mostrar los elementos que describen o caracterizan a un filósofo. José Ferrater Mora concibe filosofía haciendo lectura, a través de su escritura describe a filósofos como José Ortega y Gasset y Miguel de Unamuno en particular, pero también se adentra a un vasto universo al describir y analizar a decenas de conceptos y corrientes filosóficas en su obra enciclopédica. Desarrolla amplias bibliografías en los artículos y conceptos que él expone, teniendo en cuenta que como especialista en la historia de la filosofía no toma distancia de los marcos referenciales a los cuales enuncia, pero tampoco suele tomar partido por una posición específica.

Es importante acotar que en el análisis hecho en este trabajo de grado del concepto de integracionismo que Ferrater Mora expresa en su Diccionario de filosofía, se encuentra también una idea similar a la lectura que se hace en El ser y la muerte, con la intención de comparar los cambios que acontecen en su sistema filosófico a lo largo del tiempo. La revisión y reescritura de sus ideas y sobre todo de su sistema filosófico muestra como lo 
vivencial y existencial hace que el integracionismo sea un método dinámico, un sistema filosófico que se renueva porque cada día de existencia hay nuevas experiencias y aunque el método tenga una estructura concreta, las ideas que la integran se alimentan de nuevas realidades, realidades que hacen cambios en lo humano, en lo existencial.

Siguiendo con la lectura de El ser y la muerte, hay elementos existenciales o que hacen referencias a las lecturas de obras sobre el existencialismo que disponen un posible acercamiento de José Ferrater Mora al existencialismo, indistintamente de que él marque distancia de cualquier corriente, pero que no puede obviarse la presencia de esos elementos que revisten importancia, dan un carácter contundente, tanto de desde lo bibliográfico como de enfoque. Tomando en consideración la presente lectura que se realiza de El ser y la muerte, se identifican varios elementos que abordan desde el criticismo para luego conducir al existencialismo, como se ve a continuación:

¿Por qué decir, pues, que la realidad no es, excepto en la razón, «en
principio»? Sólo porque de admitirse lo contrario se correrá el riesgo
de confundir la realidad con los esquemas mediante los cuales se
piensa. Pero los esquemas intervienen en la compresión de lo real al
modo como los andamios en la construcción de un edificio: en tanto
que armazones provisionales, siempre a punto de ser removidos y
reemplazados por otros. Los llamados «principios de la realidad»
son, a lo sumo, principios del conocimiento de la realidad. En este
respecto Kant - el Kant de la Crítica de la razón pura- comprendió
muy bien la naturaleza de este problema. Por desgracia, desarrolló, o
dio pie para que se desarrollase, la idea según la cual los principios
del conocimiento de la realidad son principios de la realidad. Si
seguimos hablando de estos será mejor convenir en que aparecen
como principios de su conocimiento, sin necesidad de suponer por
ello que hay efectivamente principios de la realidad distintos de ésta y
en los que la realidad «metafísicamente» consistía." (Ferrater Mora,
$1979: 46)$.

Habiendo reconocido José Ferrater Mora en una entrevista la influencia que Kant tiene en su pensamiento, el pensador tampoco toma partido indefectible por la filosofía kantiana. La toma (como suele suceder en otros casos) como referencia y a la vez hace crítica de la misma para luego contrastarla:

¿Qué es así, esa realidad de la que hablo? Si el realismo y el
idealismo no bastan, y si, por otro lado, nos negamos a regresar a
una posición pre-ontológica y pre-filosófica, ¿habrá que reconocer
como única ontología válida la desarrollada, o presupuesta, por el
empirismo?” (Ferrater Mora, 1979: 46).

Este tipo de preguntas que Ferrater Mora puntualiza son precisamente para implementar su método o sistema filosófico, que le permite ese acercamiento de ideas- 
límites y a la vez mostrar acercamientos posibles entre esas ideas. Es como se ve a continuación ese acercamiento-abordaje de ideas:

"En gran parte, sí. Y no cabe duda de que buena porción de los filósofos contemporáneos, desde los de confesión positivista, hasta los de tendencia fenomenológica e inclusive existencialista, se han propuesto seguir una vía semejante a la que aquí señalo. Común a estos filósofos es la idea de que la realidad no se escinde en dos - ella y su principio, o sus principios- sino que es lo que parece ser. Como indica Sartre, siguiendo a Husserl, la realidad es - no sólo parece ser - fenómeno, y «el fenómeno... es absolutamente indicativo de si mismo». Junto con el empirismo se afirma aquí cierto «fenomenismo». Ahora bien, que la realidad parezca o que parece ser no significa que sea siempre tal como nos aparece." (Ferrater Mora, 1979: 46)

En esta cita, José Ferrater Mora infiere que el acercamiento de ideas no es algo exclusivo de su método filosófico. No hay una sola realidad, no existe un único concepto que limite los análisis. Y es aquí cuando aparece la mención a Jean-Paul Sartre y la referencia específica al existencialismo. A lo largo de la escritura de El ser y la muerte, se irá observando varias menciones a Jean-Paul Sartre, en especial tomadas de El ser y la nada, que sin duda es una muestra significativa de los elementos existenciales en la filosofía de Ferrater Mora, como se enuncia:

“ ¿Propongo, pues, frente a la ontología tradicional, un empirismo y un ontologismo críticos? Sí, también, en gran parte. Mas sin considerar esta doctrina como la única posible. La ontología según la cual la realidad no es sólo "en principio», puede expresarse de varias maneras - como el realismo y el idealismo se manifestaron de múltiples formas sin dejar de ser fieles a su común orientación general ontológica-. Lo que propongo es, pues, un modo de considerar la realidad que, sin caer en la ingenua suposición, prefilosófica y pre-ontológica, de que es tal cual aparece, afirme que no hay ningún ser -o mejor principio- oculto tras ella que la haga ser y comportarse de diversas maneras. No inquiriré aquí, de consiguiente, por lo que la realidad es "en última instancia». No inquiriré siquiera en lo real presuponiendo que nihil est sine ratione. Aun admitida esta última fórmula, hay que hacerlo en tanto que suposición secundada, fundada, como todas las otras de carácter similar, en el reconocimiento de que la razón de la realidad es ella misma" (Ferrater Mora, 1979: 47).

Es aquí donde Ferrater Mora considera que hacer filosofía significa ser amplios y libre de prejuicios y dogmatismos filosóficos. Todo lo que existe en la filosofía puede usarse para aplicarla a una metodología que busca acercarse a las realidades de la existencia, sean estas humanas, orgánicas o incluso inorgánicas. Eso también quiere decir que aunque existan formas de pensamiento, sistemas y métodos filosóficos establecidos, 
eso de ningún modo representa que no puedan ser adaptados para hacer filosofía que tome cierta equidistancia y que incluso parece ser antagónica.

"Por tanto, aunque pueda haber una ratio cognoscendi, no hay por ello necesariamente una ratio essendi. Puede argüirse que la ratio essendi es justa y precisamente la ratio cognoscendi, es decir, que las razones por las cuales $X$ es lo que es y se comporta como se comporta, son exactamente las mismas por las cuales se explica que $X$ es lo que es y se comporta como se comporta. El primer argumento es típico de las filosofías idealistas, el segundo de las filosofías realistas. Ambos argumentos son, en el fondo, el mismo: el argumento que consiste en identificar el esse con su ratio.

Rechazo esta identificación porque niego que haya una ratio essendi, esto es, que haya ningún sedicente principio de la realidad distinto de ésta y previo a ella" (Ferrater Mora, 1979: 47)

Para el Ferrater no hay una realidad enteramente idealista y tampoco hay una realidad enteramente realista, ya que de tomarse postura dogmatica ambas convergen en ser absolutistas, con lo cual no existiría diferencia a pesar de ser puntos de vista que manifiesten diversidad. Ferrater Mora continúa su argumentación:

\footnotetext{
"Puesto que, en la misma forma, y por las mismas razones que no hay ninguna realidad que sea absolutamente (únicamente y sin otras posibilidades) material y ninguna realidad que sea absolutamente (únicamente y sin otras posibilidades) mental, no hay tampoco ninguna realidad que sea absolutamente externa o absolutamente interna. Los ejemplos dados anteriormente no son pues, enteramente correctos, ya que aun en los dos casos extremos citados hay en las realidades correspondientes al interno y algo externo respectivamente. Así, toda realidad está situada entre el polo externo y el polo interno, habiendo algunos tipos de realidades, como las orgánicas, que parecen ocupar el punto central en el continuo determinado por la doble dirección de que he hablado en la sección precedente." (Ferrater Mora, 1979: 60)
}

Según las consideraciones del autor, tanto las filosofías idealistas como las realistas, aunque sean antagónicas tienden a caer en argumentos similares. Esto es lógico considerando que cada corriente de pensamiento que de alguna manera esté enmarcada en lo doctrinal y por lo tanto tener sus respectivos dogmas o tener posturas dogmáticas, posturas que le imprimen un contexto absolutista y de carácter defensivo de su respectivo credo. Es desde esa perspectiva que José Ferrater Mora muestra abierta oposición.

Es preciso para Ferrater Mora mostrar sus argumentos atendiendo su premisa de "tender puentes" sin que ello excluya la consideración de la diversidad de los pensamientos que son manejados para el fin consiguiente, que es filosofar en dos aguas y que cada una 
conserve su sustancia, sus rasgos sin intención de ser convertidos en síntesis. Es como se verá plasmado en una de las menciones que hace a Jean-Paul Sartre y en este caso a Hegel:

"Retomando el hilo del examen de los conceptos de «externo»e «interno» tal como se llevó a cabo originalmente, desde un punto más decididamente «metafísico» $y$ «especulativo», puede afirmarse lo siguiente.

Algo es calificado primariamente de externo o exterior cuando aunque no enteramente reductible a extensión y a propiedades geométricas de la extensión, se comporta como si estuviese compuesto fundamentalmente de partes extensas, con sólo un mínimo de «interioridad». Tal mínimo es indispensable; la completa eliminación de todo aspecto interior puede oportunamente «exteriorizarse». No andaba del todo descaminado Hegel al decir la exterioridad es el elementos constitutivo de la Naturaleza. El ser-en-sí que ha descrito Sartre, opaco, compacto y tupido, ese ser que es, y es lo que es, resulta asimismo muy similar a lo que he llamado «lo externo». Pero cabe establecer ciertas diferencias entre as concepciones de estos filósofos y la aquí brindada. Para Hegel la Naturaleza como exterioridad es el ser fuera de sí de la Idea; es la Idea en tanto que enajenada. 'Exterior' es aqui el nombre de un concepto metafísico, no de una determinación ontológica." (Ferrater Mora, 1979: 60)

Esta forma integracionista de filosofar es expuesta por el pensador catalán al hacer las comparaciones del ser que hay entre Jean-Paul Sartre y Hegel, teniendo constancia de la distancia entre ambas ideas y formas de pensamiento, y se puede afirmar que en este caso puede hablarse de ideas o conceptos-límites en función a la aplicación que se pretende, siendo Jean-Paul Sartre un exponente de la filosofía existencial y la dialéctica de G. W. F. Hegel que también se desarrolla en Jean-Paul Sartre por su filiación al marxismo, sin obviar que esas ideas están contenidas dentro de un campo metafísico y no ontológico (en el caso de la naturaleza en Hegel).

Puede deducirse entonces que la finalidad del integracionismo de "tender puentes" entre ideas opuestas tiene una meta ulterior: Demostrar que los pensamientos antagónicos no son del todo irreconciliables.

Se puede comparar a un ateo y un creyente en un diálogo donde cada uno expone sus ideas. Cada uno tiene su verdad, su visión del universo y de lo que lo rodea. Cada uno es la negación del otro y cada uno se reafirma en sí mismo. Pero en ese diálogo se puede llegar a coincidir que ambos, tanto el ateo como el creyente, reconocen que hay en la naturaleza conceptos o ideas sobre la energía, la materia, el diseño que hay todo lo existente y eso sería tender un puente sin que eso constituya la claudicación de una idea por la otra. 
Volviendo a las consideraciones que José Ferrater Mora mantiene sobre Jean-Paul Sartre y Hegel, el filósofo catalán acota:

“Además, la exterioridad es un «momento»-no el polo ontológicode un proceso que tiene una sola dirección: la recuperación del ser en sí mismo. En cuanto a Sartre, el «En sí» se opone absolutamente al «Para sí»; por eso indica dicho autor que «el en sí no tiene un dentro que pudiese oponerse a un fuera y que sería análogo a un juicio, a una ley, a una conciencia de sí. El En sí no tiene secretos: es macizo». De ahí que mientras en Hegel domina un monismo absoluto del proceso, se imponga en Sartre un dualismo tajante: el del ser (como «ser en sí») y la conciencia. A diferencia de estas concepciones, lo externo para mí no es ni un paso hacia lo interno, ni tampoco una absoluta oposición a él: es la tendencia que ciertos seres vivos revelan hacia la exterioridad y, por tanto, implica la posesión a su vez de un cierto, bien que mínimo, «interior»." (Ferrater Mora, 1979: 61)

En las comparaciones que refleja José Ferrater Mora en los conceptos emitidos por Jean-Paul Sartre y G. W. F. Hegel el elemento ontológico no parece ser el primordial (sabiendo la importancia de la ontología en Jean-Paul Sartre como puede observarse en su obra El ser y la nada, a la que dedica un contenido significativo,) y es cuando Ferrater en las comparaciones que hace, realiza una afirmación pertinente en lo que él considera su visión integracionista del tema Sartre-Hegel: "lo externo para mí no es ni un paso hacia lo interno ni tampoco una absoluta oposición a él”. En José Ferrater Mora hay una dualidad que además acusa en Jean-Paul Sartre, pero que está alimentada de sus ideas y de otras con las que hace comparación. Esas comparaciones sobre las realidades que ahora menciona como "inorgánicas":

"Como ejemplo de realidades con fuerte tendencia hacia la exterioridad se mencionaron antes las llamadas «realidades inorgánicas». Los predicados 'tiende a ser externo' y 'tiende a ser interno'son relativos uno al otro; se dice de una realidad, o clase de realidad, que tiende a ser externa, en realidad con alguna otra realidad, o clase de realidad, de la que se dice que tiende a ser interna, y viceversa. Así, las realidad inorgánicas, tienden a ser externas en relación con las realidad inorgánicas. Ello plantea una dificultad: ¿qué ocurriría si solamente hubiese realidades inorgánicas? A nuestro entender, podríamos seguir diciendo que estas realidades inorgánicas seguirán tendiendo hacia la exterioridad, no respecto a realidades orgánicas existentes, sino respecto a posibles realidades orgánicas emergentes de las inorgánicas." (Ferrater Mora, 1979: 61)

José Ferrater Mora retoma nuevamente su posición respecto a lo que se considera opuesto, establecer que hay una distancia entre realidades, en este caso, las realidades 
orgánicas y las inorgánicas, las cuales una no convive sin la otra, sabiendo que cada realidad obedece a su respectiva concepción, incluso que unas realidades orgánicas pueden corresponder a ser emergentes de las inorgánicas. Se observa en esta afirmación el integracionismo o más bien el "empirismo dialéctico" del que hace gala el escritor. Ahora bien ¿Cómo se sitúan estás realidades con respecto a lo ontológico? José Ferrater Mora responde:

"De este modo, «situaríamos» (ontológicamente) las realidades inorgánicas con respecto a un posible «continuo de realidades». No necesitamos sin embargo, la idea de semejante posible «continuo», puesto que nos enfrentamos con un continuo real, en el que hay realidades inorgánicas y realidades orgánicas. Dentro del esquema de este continuo real, al decir que lo inorgánico tiende a ser externo presuponemos que no lo es absolutamente. Si algo es puramente externo, no es una entidad real, sino alguna identidad «ideal»." (Ferrater Mora, 1979: 61)

En esta respuesta, José Ferrater Mora que había minimizado el uso de la ontología en sus comparaciones de ideas sobre Jean-Paul Sartre y Hegel, ahora hace el uso de la misma para situar las realidades.

El ser y la muerte es una obra que está llena de elementos existenciales, a pesar de que el pensador catalán trata de situarse en un espacio que le distingue, pero si distinción es más metodológica y no deja de notarse las influencias que recibe de aquellos a quienes analiza (aunque eso también incluye sistemas de pensamiento no existenciales, como G. W. F. Hegel por ejemplo) tomando en cuenta que no es un caso único, ya que se ha expuesto que otros pensadores están en situaciones similares (la influencia de G. W. F. Hegel en Sören Kierkegaard o en Jean-Paul Sartre) como suele ocurrir con todo pensador que tiene como referentes a quienes le anteceden y a quienes menciona o del cual hace uso a la hora de hacer su propio ejercicio filosófico.

De las realidades orgánicas e inorgánicas, se podrá ver más en la lectura que se realizará en el presente trabajo sobre la obra de José Ferrater Mora titulada De la materia a la razón (1979). 


\title{
CAPÍTULO 3: LA ONTOLOGÍA DE LO EXISTENCIAL EN JOSE FERRATER MORA
}

En su artículo Ferrater Mora y la Ontología contemporánea (1984) Carlos Nieto Blanco sostiene:

\begin{abstract}
"La ontología es concebida por nuestro autor como un discurso sobre la realidad con pretensiones de establecer conjeturas sobre la misma, aún si ellas deben pasar por criterios lógico-semánticos. Tal y como lo entiende Ferrater Mora, el trabajo en ontología consiste básicamente en categorizar la realidad" (Nieto Blanco, 1984).
\end{abstract}

Nieto Blanco en su libro La filosofía en la encrucijada: perfiles del pensamiento de José Ferrater Mora (1985), ha permitido desde su publicación orientar el estudio del conocimiento ontológico ferrateriano. Allí, secciona su análisis en cuatro fragmentos, donde los tres primeros atienden a la trilogía de obras autoría de José Ferrater Mora, inscritas en dicha temática, estas son: El ser y la muerte (1962), El ser y el sentido (1967) y De la materia a la razón (1979), concluyendo con un apartado de apreciación de sus aportes en relación con sus coetáneos.

Caracterizando la ontología, Nieto (1984) explica que se debe entender que en la medida de que el mundo es bosquejado (no admitiendo duplicaciones platónicas) ésta se nutre de una concepción 'monista' que la circunscribe con el ámbito natural, con lo cual le conecta al 'naturalismo', pero que en la medida en que en ese mundo son admitidos diferentes tipos de realidades, van así emergiendo unos y otros, considerando una llamada ontología 'emergencista', se constituye además un nivel físico que se trasforma en básico dando paso a una concepción 'materialista'. Sin dejar de tomar en cuenta que en la medida en que los niveles guardan una relación entre sí, es posible definir entidades concretas conjeturando una llamada 'ontología continuista' que expresará una relación dialéctica entre lo uno, es decir, 'un solo mundo' y lo múltiple que representaría 'varios niveles'.

\footnotetext{
"Considero que en la ontología de Ferrater Mora existen ingredientes de la fenomenología, de la filosofía analítica y del naturalismo. Considero también que tales ingredientes se dan en diferente proporción y medida y con mayores acentos en una u otra obra, pero que, en cualquier caso, se dan en toda su obra si ésta la consideramos como una unidad. Añado -redundantemente- que la ontología de Ferrater Mora se alimenta de estas tres tradiciones" (Nieto Blanco, 1984: 210).
}

Carlos Nieto Blanco invita a identificar a la ontología de José Ferrater Mora como una ontología 'pluridireccional' propia de un filósofo que se autoidentifica como 
'integracionista'. Será José Ortega y Gasset la referencia directa con quien Nieto Blanco acople a Ferrater Mora, dado las implicaciones de su 'fenomenología mundana', la cual lo situará adelantado a su tiempo, y que como evidenciará en su obra Meditaciones del Quijote (1914) plasmará un combate con el idealismo.

\begin{abstract}
"El programa de Ferrater, en la medida en que va a acentuar también este punto de partida, guarda una filiación orteguiana y muestra también un parecido, más que con ningún otro fenomenólogo existencial, con Merleau-Ponty, cuyo Prólogo a su Fenomenología de la percepción, que data de 1945, se muestra similar con algunas tesis orteguianas" (Nieto Blanco, 1984).
\end{abstract}

José Ferrater Mora quien a reconocido su deuda con José Ortega y Gasset, en opinión de Carlos Nieto Blanco (1984) se alza como uno de los dos españoles, el otro será Xavier Zubiri, quienes han construido obras que se han convertido en autenticas creaciones alimentadas por la fuerza estimulante orteguiana.

En Ortega y Gasset: etapas de una filosofía (1973), José Ferrater Mora considera que no hay «realidad en cuanto a realidad» ni «ser en cuanto ser» lo que surge más específicamente es el ser que emerge como respuesta a lo humano, lo que relativiza el problema del ser, pues tal como lo expresa José Ferrater Mora en El ser y el sentido (1967) no existe una «realidad-ser» pues se estaría confundiendo «nombrar» con «significar», dado que para el filósofo el ser es el «simple hecho de que las realidades sean».

José Ferrater Mora al igual que José Ortega y Gasset mostrará una clara crítica a toda tesis idealista, sólo falta conectarse con las ideas compartidas en las primeras páginas de $E l$ ser y el sentido, lo que además será una explícita declaración de «no salirse del mundo, de la realidad de lo que hay». El hecho entonces será plantearse el ser como una expresión que se manifiesta no sólo como lo que está ahí, que representa la 'facticidad', es decir la actualidad, sino también como 'ir siendo', que conecta la realización de posibilidades de la realidad que deviene.

"La inserción del discurso ontológico ferrateriano con la tradición analítica tiene que ver, por el contrario, con aquellas posturas que en su seno han abogado por algo más que hacer metafísica lingüística, señalando que, a la postre, "no hay más que palabras», es decir, con aquellas tendencias que, si bien han privilegiado la perspectiva o el acceso lingüistico a la realidad, esto lo han hecho para establecer conjeturas sobre esa realidad, sobre el mundo y no sólo sobre el lenguaje. Del mismo modo que una ontología reviste, cuando menos, la forma de un discurso y en este sentido es lingüística, podemos decir que la lectura lingüística de Ferrater se hace en clave ontológica." (Nieto Blanco, 1984). 
Carlos Nieto Blanco en su trabajo "La filosofía en la encrucijada. Perfiles del pensamiento de José Ferrater Mora" (1985) expuso además que su impresión acerca de lo que consideró se trató de una de las principales inquietudes investigativas para José Ferrater Mora:

\begin{abstract}
"Una preocupación de primer orden por los temas ontológicos, un permanente esfuerzo por penetrar en el sentido de las más variadas tendencias del pensamiento contemporáneo, para cuya «coexistencia pacifica» ha reclamado constantemente el dialogo entre ellas, así como unas raíces en la cultura catalana mediante las que ha configurado su sentido de lo hispánico, ha ido definiendo la personalidad filosófica que lleva el nombre de José Ferrater Mora. En ella se cruzan los caminos por los que ha discurrido una buena parte del pensamiento filosófico contemporáneo." (1985: 16).
\end{abstract}

En el sistema filosófico de Jose Ferrater Mora, la ontología no se inscribe dentro de los idealismos más bien está incorporada en la realidad y por eso se puede hacer filosofía incluso usando recursos lingüísticos que no necesariamente tributan a una ciencia del lenguaje, ya que además la filosofía tiene su propio lenguaje, y se puede hacer filosofía a través de las indagaciones del lenguaje.

12. El existencialismo y la filosofía existencial en José Ferrater Mora.

Exponer elementos existenciales dentro de la filosofía de José Ferrater Mora, invita a realizar una rigurosa lectura de su visión sobre otros filósofos, de los cuales, se afirma han hecho contribución al existencialismo como corriente de pensamiento. Es posible partir en primer lugar de la amplia definición que José Ferrater Mora realiza en una de sus más célebres obras académicas, el Diccionario de filosofía. Tomando en consideración las calificaciones, caracterización y conceptualización de pensadores que usaron el vocablo existencialismo para delimitar su respectiva corriente o visión.

De igual forma es importante mencionar su concepción de la "filosofía de la existencia", plasmada en su Diccionario de filosofía, así como los términos existenciario equivalente a existenzial en referencia a la obra de Martin Heidegger que define la estructura ontológica de la existencia que se llamará entonces existenciaridad.

También se considera en este análisis el término existencia desarrollado por José Ferrater Mora en su obra, ya que desde lo lingüístico y filosófico hay una conexión indefectible entre existencialismo y existencia. 
Se comenzará por citar la definición de existencialismo en dos partes para luego proceder con las consideraciones pertinentes:

"Se ha abusado tanto del vocablo 'existencialismo' que, como han indicado varios autores allegados a esta tendencia (entre ellos Sartre), ya no significa apenas nada. Se han calificado de "existencialistas", en efecto, no sólo ciertas tendencias filosóficas contemporáneas, sino muchas de las tendencias filosóficas del pasado, antiguas y modernas. Se ha dicho, por ejemplo, que los jónicos, los estoicos, los agustinianos, los empiristas y muchos otros han sido de algún modo "existencialistas". Se ha dicho también que son "existencialistas" todas las filosofías en las que se ha afirmado, o se ha dado por supuesto, el llamado "primado de la existencia (...) sobre la esencia (...)". Por eso se ha hablado del "existencialismo" de Santo Tomás de Aquino, por lo menos a diferencia del "esencialismo" de Avicena.

Para combatir este abuso del término 'existencialismo' hay que limitar la aplicación del vocablo a cierta época y, dentro de ello, a ciertas corrientes o actitudes filosóficas.

Desde este punto de vista el origen del existencialismo se remonta solamente a Kierkegaard (...), el cual lanzó por vez primera el grito de combate: "contra la filosofía especulativa [principalmente la de Hegel], la filosofía existencial". Con ello abogó por un "pensar existencial" en el cual el sujeto que piensa -este hombre concreto y, como diría Unamuno, "de carne y hueso"- se incluye a sí mismo en el pensar en vez de reflejar, o pretender reflejar, objetivamente la realidad. Este pensar "existencial" que da origen al "existencialismo" es muy a menudo de tipo "irracionalista" (...), Pero puede ser, si es menester, racionalista. En efecto, un pensador racionalista que incluyera su propio ser en su pensar, pensaría asimismo "existencialmente". Esto es, por lo demás, lo que sucedió con Sócrates, a quien Kierkegaard tenía muy presente.

Por tanto, lo primero que hace la filosofía existencial -o, mejor dicho, el hombre que piensa y vive existencialmente- es negarse a reducir su ser humano, su personalidad, a una entidad cualquiera. El hombre no puede reducirse a ser un animal racional, pero tampoco a ser un animal sociable, o un ente psíquico, o biológico. En rigor, el hombre no es ningún "ente", porque es más bien un "existente"-y, en puridad, "este existente"" (Ferrater Mora, 2004: 1174-1175).

Esta respectiva cita es contundente en relación a establecer una delimitación de lo que es el existencialismo, ya que más allá de las concepciones e interpretaciones que estudiosos, académicos y filósofos tributarios del existencialismo han aportado, es Sören Kierkegaard quien da origen al término y lo define. Una definición generadora del establecimiento de su propio sistema filosófico, que lo lleva a convertirse en un antagónico de la filosofía entonces en boga, la de Hegel, a la que el filósofo danés considero una filosofía especulativa, que está lejos de la realidad cercana. 
José Ferrater Mora argumenta que Sören Kierkegaard trasciende la racionalidad de definir u objetivar la realidad a partir de algún tipo de sistematización o dicho de otra manera: se niega a una concepción absoluta o reduccionista de que el hombre es razón o entidad. Sin embargo, José Ferrater Mora reconoce la contradicción de esta filosofía, ya que si el mismo hombre a través de su pensamiento, sentimiento y experiencia se define, por lo tanto hay razón en sí mismo.

Será una ruta de desarrollo investigativo el análisis de forma somera de la filosofía de Kierkegaard, a partir de su obra El concepto de la angustia (publicada originalmente en 1844), la cual permite establecer el génesis de la cosmovisión sobre el existencialismo y la filosofía existencial en José Ferrater Mora.

Según Demetrio G. Rivero, estudioso de la obra del filósofo danés, en el prólogo de la obra, comparte:

"El concepto de la angustia y La enfermedad mortal representan
el origen fontal del existencialismo, que en esta su propia fuente,
se manifiesta como una filosofía personalista, concreta y, sobre
todo, cristiana. Por eso ningunos otros lugares más a propósito
para calar hasta el fondo metafísico que alcanzan los análisis
existenciales del pionero danés" (1984: 11).

Sören Kierkegaard desnuda la moral de la cristiandad, pero a su vez reafirma el ser cristiano como una justificación de la vida y la existencia. Los individuos o personas son la existencia y la vez lo son la especie o su conjunto. A su vez constituyen una "síntesis de lo temporal y lo eterno". Hay un cuestionamiento de la praxis del cristianismo de su época, pero a la vez se mantiene firme en los límites del dogmatismo del pecado original y de la salvación por la fe. En todo este universo "existencial", ya que de acuerdo a su creencia, es ser humano existe porque Dios le ha creado, Dios es la fuente y origen de todo, por lo tanto Dios también es existencia, siendo el ser parte de un todo. Ese Dios establece dictámenes, reglas, mandamientos, pese a que también dota de libre albedrío, pero hay límites de cómo vivir y estar fuera de esos límites es pecar.

Al pecar la perspectiva existencial cambia ya que emerge la angustia. La angustia define desde sus caracterizaciones la racionalidad del ser, sus acciones sean voluntarias o involuntarias. El pecado trae como consecuencia la desaprobación, la desaprobación conlleva a una redención o en su defecto a la muerte, la muerte que puede ser tormento, estar al margen del favor de Dios, lo que también significa angustia y sufrimiento eterno. 
Pero la fe sería el camino a la salvación de ese pecado original, de tal manera que la angustia tendría un fin.

Lo que no es fácil de descifrar o interpretar en la lectura de El concepto de la angustia, es si la angustia tiene fin antes o después de morir. Pero basado en la Biblia, la obra del pensamiento de Dios en concordancia a los dogmas cristianos, "la paga del pecado es la muerte" (Romanos 6:23. Versión Reina-Valera: 1960), por lo tanto la angustia habita existencialmente a lo largo de la vida de todo ser que existe, ya que existir cristianamente es reconocer que se nace pecador y que sólo la fe lo puede salvar. La fe que se manifiesta en obras, no sólo la creencia vana sin acción. La angustia es un habitante del pensamiento existencial.

Permitiéndose afirmar que de acuerdo al filósofo cristiano, la angustia es el leitmotiv de su propuesta filosófica, el fundamento de su sistema filosófico que además se ve plasmado en otras de sus obras como, Migajas filosóficas (1844) y Temor y temblor (1843), ésta última resume a la resignación o total confianza en Dios como antelación de la fe, la esperanza de los designios o señales divinas, que por muy absurda que pueda parecer esa realidad, Dios concederá la gracia siempre que exista la convicción absoluta y la creencia ciega en Él, que se ilustra a través del relato de Abraham contenido en el Génesis, donde Dios le pide que sacrifique a su hijo Isaac para probar la certeza de su fe absoluta.

Como se profundizará en la sección acerca de las influencias filosóficas que contribuyeron al perfil intelectual de José Ferrater Mora. Sin duda alguna, la obra de Kierkegaard es de vital importancia en su cosmovisión existencialista, dado que tras analizar las obras más representativas contenidas en una parte significativa de su bibliografía, darán un amplio panorama de su visión filosófica acerca del existencialismo.

Siguiendo el análisis del concepto de Existencialismo que Ferrater Mora plasmó en su Diccionario de filosofía, que además sigue dando luces acerca de su cosmovisión sobre el existencialismo y la filosofía existencial, se encuentra que:

\footnotetext{
"El hombre no es, pues, ninguna substancia, susceptible de ser determinada objetivamente. Su ser es un constituirse a sí mismo. En el proceso de esta su autoconstitución existencial, el hombre puede engendrar el ámbito de inteligibilidad que le permitirá comprenderse a sí mismo, y a su situación con los demás y en el mundo. Para el pensar existencial, el hombre no es "conciencia" y menos aun "conciencia de la realidad": es "la realidad misma".
} 
El existencialismo es, así, primariamente, un modo de entender la existencia en cuanto existencia humana. Se ha hablado por ello de "antropocentrismo existencial" o "existencialista". Ahora bien, partir de la existencia humana como un "existir" no significa siempre afirmar que solamente hay existencia humana. Tal afirmación no se encuentra ni en Kierkegaard ni tampoco en autores como Chestov, Berdiaex o Marcel. En otras palabras, el existencialismo a que da origen el citado "pensar existencial" no es necesariamente inmanentista. Pero aun cuando rechazan el punto de vista "antropocéntrico", los autores existencialistas -o llamados talesreconocen que la existencia, y en particular la existencia humana, es de algún modo algo "primario". Sólo desde ella es posible, y legítimo, filosofar.

Se ha intentado a menudo definir 'existencialismo' sin que se haya encontrado una definición satisfactoria, (entre otras razones, porque el existencialismo, especialmente en cuanto "actitud existencial", rehuye cualquier definición). A lo más que se ha llegado es a subrayar ciertos temas que aparecen muy a menudo en la literatura filosófica existencialista y paraexistencialista" (Ferrater Mora, 2004: 1175).

A partir de esta acotación que reconoce la existencia de corrientes sucedáneas del existencialismo, José Ferrater Mora enlistará como temas válidos del existencialismo propiamente dicho, una selección de tópicos que pueden considerarse como la definitoria temática de las indagaciones en principio abordadas desde su visión existencial; externa a lo expresado en el Diccionario de filosofía:

"Estos temas son, entre otros, la subjetividad, la finitud, la contingencia, la autenticidad, la "libertad necesaria", la enajenación, la situación, la decisión, la elección, el compromiso, la anticipación de sí mismo, la soledad (y también la "compañia") existencial, el estar en el mundo, el estar abocado a la muerte, el hacerse a sí mismo. Nos hemos referido a estos temas en varios artículos de la presente obra. Rozaremos asimismo algunos en este artículo al hablar luego con más detalle de varias corrientes existencialistas o consideradas tales. Se ha intentado asimismo a menudo clasificar las corrientes existencialistas. Se ha hablado en este sentido de existencialismo eológico, existencialismo cristiano, existencialismo ateo, y hasta existencialismo marxista. Se ha ensayado describir la genealogía del existencialismo contemporáneo en general y al efecto se ha traído a colación no sólo a Kierkegaard, sino también a Nietzsche, el pragmatismo, la fenomenología, etc." (Ferrater Mora, 2004: 1175).

En este fragmento se observa que hay un amplio panorama del significado del existencialismo que toma distancia de la visión kierkegaardiana, sin que este amplio horizonte deje de forma alguna de tributarle al filósofo danés.

José Ferrater Mora deja claro que si bien es cierto no es posible concebir una declaración definitiva del existencialismo, tampoco se puede establecer que sea del todo 
inmanente. $\mathrm{Y}$ es por ello que surgen varias corrientes existencialistas que se relacionan a diversos pensamientos y sistemas filosóficos tan diversos y en esencia tan opuestos como Friedrich Nietzsche al que se le considera un antihegeliano, como existencialismo marxista que le tributa indefectiblemente a Hegel. Se habla hasta de una fenomenología existencialista siendo la fenomenología una visión filosófica ampliamente desarrollada por G. W. F. Hegel a lo largo de toda su obra, aunque también por Immanuel Kant y David Hume, entre otros autores.

Volviendo a la consideración ferrateriana de que no existe una definición satisfactoria ya que el existencialismo en sí mismo rehúye a cualquier definición, el filósofo español busca describir la amplitud del mismo sin establecer un orden reduccionista como ocurre con otras obras académicas no especializadas en filosofía que intentan definir el existencialismo en una mínima expresión y para ello resulta útil recurrir a la definición que la Edición del Tricentenario del Diccionario de la lengua española de la Real Academia Española, que establece "Doctrina que trata de fundar el conocimiento de toda realidad sobre la experiencia inmediata de la existencia propia" (2014: pág). Pudiéndose afirmar que el existencialismo está lejos de ser una doctrina unilateral reducida, sino que la misma dispone de un carácter tan diverso como el número de pensadores autodefinidos existencialistas.

Otro tópico enunciado por José Ferrater Mora es su afirmación de que existe una literatura filosófica existencialista y paraexistencialista que aborda tan diversos temas que permite proponer la elaboración de una enciclopedia sobre el existencialismo. Al final del artículo sobre existencialismo, se observa una larga lista de obras citadas por nuestro filósofo que ocupa más de dos páginas y que hacen de ese artículo uno de los más elaborados y prolíficos en su obra académica.

Vale reiterar que José Ferrater Mora considera que hay tantos existencialismos como existencialistas se reafirman, ya que menciona en esa diversidad un existencialismo eológico, existencialismo cristiano, existencialismo ateo, existencialismo marxista que además llevaría a establecer una amplia genealogía existencialista contemporánea, que como se ha afirmado con anterioridad, constituye todo un universo que hoy se pierde de vista, que no sería una tarea fácil de catalogar. Ahondando en este interesante artículo de José Ferrater Mora, que para esta tesis constituye una bitácora de la cosmovisión existencial, se atina: 
"En vista de la dificultad tanto de definir el existencialismo como de dar cuenta de sus contenidos o de clasificarlo en forma aceptable para la mayor parte de autores o historiadores de la filosofía contemporánea, presentaremos en este artículo varias clasificaciones propuestas, al hilo de las cuales se puede dar cuenta de algunas tendencias existencialistas o semi-existencialistas contemporáneas. A base de estas clasificaciones discutiremos luego algunas formas básicas de existencialismo y algunas de las reacciones suscitadas por "el movimiento existencialista" en general.

Según Emmanuel Mounier (Introduction aux existentialismes [1947], pág. 11), el existencialismo puede compararse a un árbol alimentado en sus raíces por Sócrates, por el estoicismo y por el agustinismo. Estas raíces producen filosofías como las de Pascal y Maine de Biran. El tronco del árbol representa a Kierkegaard. Desde el tronco se extiende una ancha copa en la cual se hallan representados, en una ramificación harto compleja, la fenomenología, Jaspers, el personalismo, Marcel, Soloviev, Chestov, Berdiaev, la teología dialéctica (sin olvidar el "judaismo trascendental" de Buber), Scheler, Lansberg, Bergson, Blondel, Laberthonnière, Nietzsche, Heidegger, J.-P. Sartre (terminal "izquierdo" del "movimiento")" (Ferrater Mora, 2004: 1175-1176).

De acuerdo a lo enunciado por José Ferrater Mora, al inicio de la consideración del concepto sobre existencialismo, él mismo expone claramente que se alude muchas veces con abuso, la asignación del término para designar diversas corrientes de pensamiento, las cuales de acuerdo a su caracterización no necesariamente obedecen a la clasificación de existencialista, así prosigue explicando en el siguiente fragmento:

"Siguiendo el mismo símil se podrían incluir en esta copa el pragmatismo, Unamuno, Ortega y Gasset y otros muchos autores.

Esta clasificación de Mounier peca por exceso. Mounier califica de "existencialistas" a no pocos autores que, como Bergson, no han sido tales, y a otros que, como Heidegger y Ortega y Gasset, han rechazado legítimamente ser considerados tales. Jacques Maritain ha propuesto otra clasificación: según ella, hay por un lado un existencialismo propiamente existencial y un existencialismo meramente académico. El primero es "el existencialismo en acto vivido o ejercido". El segundo es "el existencialismo en acto significado" como máquina de ideas y aparato para confeccionar tesis. Nicola Abbagnano ha indicado que hay diversas formas de existencialismo según el modo como se establezca la "relación" entre la existencia y el ser. Siendo fundamental en todo existencialismo la idea de que la existencia no es ser, sino relación o rapporto con el ser, tal relación puede ser interpretada de tres maneras. La primera se refiere al punto de partida: A la nada de la cual se supone que emerge la existencia. La segunda se refiere al punto de llegada: Al ser hacia el cual "se dirige" la existencia. La tercera se refiere a la unidad del punto de partida con el de llegada: A la relación misma. En el primer caso, se define 'existencia' como 'imposibilidad de no ser nada'. En el segundo caso, se define 'existencia' como 'trascendencia' 
y ésta como 'imposibilidad de ser un ser'. En el tercer caso se define 'existencia' como 'posibilidad de ser la relación misma con el ser'. Abbagnano dice que el primer tipo de existencialismo es propio de Heidegger; que el segundo ha sido representado especialmente por Jaspers, y que el tercero es el del propio Abbagnano. La insistencia en la "posibilidad" excluye, según Abbagnano, retrotraer la existencia al modo de ser propio de las cosas. En efecto, la existencia puede relacionarse o no con el ser, acentuar o debilitar su rapporto con él. Otras clasificaciones presentadas son del tipo de la ya aludida antes: Existencialismo "ateo" (Heidegger, Sartre) y existencialismo "cristiano" (Jaspers, Marcel, Lavelle)" (Ferrater Mora, 2004: 1176).

José Ferrater Mora coloca en evidencia la insuficiente consistencia argumental, para demarcar un territorio tan vasto número de corrientes en una misma delimitación, aunque tengan similitudes discursivas o que parezcan definibles de forma ontológica. El filósofo barcelonés advierte:

"Todas estas clasificaciones ofrecen inconvenientes. Por lo pronto, se incluye en ellas con frecuencia a Heidegger. Pero si la filosofía de Heidegger es un "existencialismo", lo es sólo en el sentido de una preparación para una ontología: "sólo en este sentido ontológico -ha escrito Fritz Kaufmann- figura el hombre como centro de la metafísica de Heidegger" (Philosophy and Phenomenological Research [...]). Se ha dicho por ello que una filosofía es existencialista sólo cuando se apoya en lo óntico (...), pero no cuando se apoya en lo ontológico. Es cierto que algunos críticos han declarado que Heidegger no ha podido pasar, muy a pesar suyo, del campo del "análisis existencial" a la ontología, y que, en general, tal paso no es posible. Pero lo estimamos dudoso. Por otro lado, las clasificaciones en cuestión no tienen siempre en cuenta la diferencia entre "actitud existencial" y "pensamiento existencial". Sólo este último merece ser llamado "existencialismo". En efecto, el existencialismo no es, no debe ser, una mera "actitud" o inclusive una simple "toma de posición". El existencialismo es, o debe ser, una filosofía" (Ferrater Mora, 2004: 1176).

Este fragmento reitera la distinción acerca de los análisis que enmarcan o delimitan la filosofía existencialista, los cuales no deben definirse por cuestiones insustanciales como una toma de posición, ya que se erra por etiquetar cualquier expresión de pensamiento, que por simples enunciados puedan descontextualizarse. José Ferrater Mora continuaría argumentando:

"Ciertos autores niegan que tal filosofía sea posible. Manifiestan que desde el momento en que se adopta una actitud existencial se excluye toda posible "racionalización" de la existencia, y que sin tal "racionalización" no es posible, o no es legítimo, hablar de filosofía. Otros autores niegan la posibilidad de tal filosofía alegando que los análisis de la existencia humana en que son pródigos los autores existencialistas son, a pesar de lo que dichos autores pretenden, de 
carácter empírico-psicológico y no tienen ningún carácter propiamente "existencial".

Los autores que admiten la posibilidad de una filosofía existencial no están siempre de acuerdo en las bases de tal filosofía. Según ha indicado José Gaos (...) el existencialismo más difundido sufre de una "falsa unilateralidad exclusiva de sus bases". Tal carácter negativo se debe en gran parte a que para estas filosofías el cristianismo es visto desde fuera, como un juego filosófico; se toma, por lo tanto, uno de sus extremos -Pascal, Kierkegaard, experiencias de la angustia, de la nada, etc.-, y se olvidan otros extremos -los Evangelios, el franciscanismo, etc.-, donde, en vez de la inquietud angustiada, hay una inquietud esperanzada y una serie de vivencias -amor, alegría, etc.- que el existencialismo usualmente desatiende o desestima" (Ferrater Mora, 2004: 1176-1177).

Si se tratará de hacer una delimitación por los asuntos que autores como Sören Kierkegaard que van ligados a la teología, entonces cualquier autor o filósofo que se considere cristiano estaría metido en la misma clasificación, a sabiendas de que lo que se considera existencialismo tiene una génesis reciente, sin descartar que se alimenta de referentes anteriores a lo definido por el filósofo francés en El concepto de la angustia (1844). Prosiguiendo con la lectura, José Ferrater Mora sigue manifestando un audaz análisis:

"Como señala ya Louis Lavelle, consistiendo primariamente la
existencia en emoción de existir (la cual nos proporciona un acceso al
ser), tal emoción no puede ser simplemente reducida a la angustia:
tiene, dice Lavelle, una fase positiva que es el émerveillement
d'exister, es decir, el "encontrar en mí una participación en una
realidad que no cesa de constituirme" (Curso en el Collège de France
sobre Los fundamentos de la metafísica, 1945-1946). Podríamos decir
inclusive que la mencionada unilateralidad es debida a un factor
fundamental y realmente único: A que se insiste en que el trascender
de la existencia no tiene otra finalidad que la constitución de la
propia existencia. Cuando así no ocurre, la unilateralidad
desaparece, y entonces todos los modos de la finitud existencial son
posibilidades y condiciones, pero no el constitutivum metaphysicum
de la existencia. Por eso se ha subrayado también que el inevitable
trascender de la existencia humana se descubre en el hecho de que
esta existencia no puede "vivir por sí". No todos los autores, sin
embargo, están de acuerdo en el significado de esta última
restricción" (Ferrater Mora, 2004: 1177).

Se habla de restricciones al marco de un pensamiento que puede tener características de unilateralidad como es el caso de Louis Lavelle, que según su apreciación lo que constituye al ser no es algo que solamente deba ser reducido a la angustia, que en lo metafísico pasa a lo trascendental. En cuanto a los fundamentos de la existencia, José Ferrater Mora atiende lo siguiente: 
"Algunos sostienen que si el fundamento de la existencia no es la propia existencia, entonces debe necesariamente recurrirse a Dios. Otros sostienen que basta con reconocer un reino trascendente de valores. Otros, finalmente, encuentran el fundamento de la existencia en la Naturaleza. Con ello las cuestiones acerca de la existencia vuelven a suscitar los problemas tradicionales y representan, en cierto modo, una reformulación de estos problemas.

Ha habido por lo menos tres actitudes en el pensamiento actual frente al existencialismo: la completa indiferencia; la oposición cerrada; y el esfuerzo por "superar" el existencialismo desde dentro.

La indiferencia se ha manifestado a veces mediante el simple desdén; a este efecto ha sido corriente decir que las tendencias existencialistas son o puro patetismo o puro verbalismo (o ambas cosas a un tiempo). La oposición cerrada ha partido a veces de los que en otras ocasiones han manifestado indiferencia; tal es el caso de no pocos autores de tendencia "analítica". Se ha dicho (por ejemplo, A. J. Ayer, cuando menos en una cierta fase de su pensamiento) que el existencialismo es simplemente un "abuso del verbo 'ser'". Otros filósofos hostiles al existencialismo lo han combatido desde posiciones consideradas por ellos como firmemente establecidas (como marxismo o neoescolasticismo)" (Ferrater Mora, 2004: 1177).

Una de las claves -en este fragmento del artículo-, es la mención por parte de José Ferrater Mora de un movimiento existencialista, al que él mismo coloca entre comillas, pero que en definitiva marca un hito, ya que generó innumerables obras en torno al existencialismo que son influyentes en la filosofía contemporánea, que permiten visualizar formas básicas y tendencias existencialistas, semi-existencialistas o filo-existencialistas, lo que seguramente justifica que por esa razón cite al filósofo cristiano francés Emmanuel Mounier, fundador del movimiento personalista, corriente filosófica de la cual se afirma que Immanuel Kant y Sören Kierkegaard constituyen sus precursores.

Emmanuel Mounier asevera, citado por José Ferrater Mora (2004: 1176), que: Kierkegaard representa el "tronco" del árbol del existencialismo y que sus raíces se remontan a Sócrates, los estoicos y San Agustín. Entonces el existencialismo entronca con la filosofía griega en primer término y luego al más destacado pensador de la cristiandad, San Agustín.

Emmanuel Mounier menciona la vasta copa de la que se desprenden diversas orientaciones, incluso indica a Jean-Paul Sartre como terminal izquierdo del movimiento, corrientes filosóficas que hacen del existencialismo uno de los movimientos filosóficos más reconocidos en la contemporaneidad. Sin embargo, José Ferrater Mora vuelve a señalar la observación que hace al principio de su magistral artículo, al decir que Mounier 
peca en exceso al clasificar a muchos pensadores con la etiqueta existencialista, pensadores que en vida negaron pertenecer a ese movimiento y que jamás consideraron sentirse existencialistas. Pero no sólo Emmanuel Mounier reconoce en el existencialismo un infinito cosmos del logos, término griego considerado aquí desde la perspectiva de Heráclito o incluso desde la consideración freudiana. Además de Emmanuel Mounier se encuentra Nicola Abbagnano, filósofo italiano que se definió a sí mismo en la corriente del existencialismo positivo, demarcándose de otros pensadores como Karl Jaspers y Martin Heidegger, a los que consideraba dentro del entorno del existencialismo negativo.

Es importante hacer mención del filósofo católico francés Jacques Maritain que propone clasificar el existencialismo en dos grandes bloques, por un lado el existencialismo propiamente existencial y el existencialismo meramente académico. Antes de seguir avanzando en este análisis de la concepción del existencialismo según José Ferrater Mora, se puede hacer la interrogante de si el intelectual podría ubicarse en uno de esos dos bloques, una pregunta considerable para reflexionar en el epítome de esta tesis, considerando la filosofía existencial en José Ferrater Mora, si era un existencialista existencial o un existencialista académico. Pudiera ser que su obra obedezca a ambos aspectos, la amplitud de la misma es prolífica.

Considerando además que en la Enciclopedia de obras de filosofía de Franco Volpi (2005: 679-681) en el artículo dedicado al ilustre filósofo, se describe que el método usado por Ferrater Mora es el integracionismo o empirismo dialéctico, dominando los temas existenciales, método que determina que su obra obedezca a ambos aspectos, ya que el integracionismo trata de construir un sistema abierto.

Recordando que José Ferrater Mora expone que algunos oponentes del existencialismo afirman que es simplemente un "abuso del verbo ser" y también alude a que es "puro patetismo" o "puro verbalismo" en el artículo desarrollado en el Diccionario de filosofía. Estas afirmaciones no sólo vienen de los detractores y opositores del existencialismo, sino también de autores que han desarrollado sus tesis existencialistas y que convienen que el existencialismo debe ser superado desde dentro. Los opositores más hostiles simplemente lo desdeñan.

Con este análisis sobre el existencialismo de acuerdo al extenso artículo de José Ferrater Mora, se procederá a exponer su contenido final, pero con acotaciones pertinentes en varios puntos: 
"En cuanto a los esfuerzos por superar el existencialismo "desde dentro", se han llevado a cabo por varios existencialistas. A modo de ejemplo mencionamos a Roberto Giordani, el cual en su obra sobre el "transexistencialismo" (...) se ha propuesto superar no sólo el "existencialismo" de Heidegger (o "procedente de Heidegger"), sino también el derivado de la dialéctica hegeliana. Según Giordani, la dialéctica debe ser sustituida por la apodíctica, la cual va de lo negativo a lo positivo absoluto en todas las esferas: de lo material a lo espiritual a través de lo corporal; del ser al existir por el devenir; de la no-temporalidad a la eternidad por la temporalidad; de la particularidad a la personalidad por la individualidad; de lo inconsciente al estado de vigilia absoluto por la conciencia; de la exterioridad a la interioridad por la ambigüedad de ambas. Giordani pretende que su paso de lo negativo a lo positivo no puede ser equiparado a la dialéctica hegeliana, en la cual dos entidades indeterminadas (como el ser y la nada) dan origen a una entidad determinada (como el devenir)" (Ferrater Mora, 2004: 1177).

Las consideraciones de las diversas formas de existencialismo han sido tópico de encarnizados debates, que incluso buscan trascender el existencialismo desde adentro (aquellos autores que tributan al mismo, que se autodefinen existencialistas, pero con intención de superarlo), por eso lo enunciado por Roberto Giordani, quien sugiere pasar de lo negativo a lo positivo, pero nuevamente José Ferrater Mora cuestiona esas posturas por su considerable ambigüedad. Siguiendo el curso de la parte final del artículo, se procede a dar lectura sobre los acontecimientos del pensamiento existencialista, en las posteriores interpretaciones generadas:

"Entre las discusiones que ha suscitado el existencialismo en las últimas décadas mencionaremos dos: una es la interpretación de esta tendencia desde el punto de vista histórico; la otra es su relación -o falta de relación - con otras filosofías contemporáneas.

En lo que toca al primer punto, las respuestas dadas han solido depender de posiciones filosóficas $-y$ a veces político-socialespreviamente adoptadas. Así, por ejemplo, el existencialismo es interpretado por los marxistas como la filosofía de la burguesía en su estado de degeneración y descomposición; por muchos "tradicionalistas" (en el sentido de "partidarios de la tradición filosófica" y en particular de una philosophia perennis), como una de las más peligrosas manifestaciones del ateísmo moderno; por los racionalistas, como una explosión antirracionalista, hostil a la ciencia y a toda sana razón humana; por muchos individualistas, como una reacción saludable de la persona contra las amenazas de esclavitud suscitadas por todo género de totalitarismos. En todos estos casos, la interpretación se refiere más a la función que el existencialismo tiene, o se pretende que tenga, dentro de la sociedad contemporánea, que a los contenidos mismos de tal filosofía, a los que nos hemos referido en el resto de este artículo. 
En cuanto al segundo punto, el existencialismo sostiene relaciones muy matizadas con otras direcciones contemporáneas" (Ferrater Mora, 2004: 1177-1178).

José Ferrater Mora expone las consideraciones de autores existencialistas, en interpretaciones que parten desde sus influencias en la sociedad contemporánea como función, pero sin una profunda referencia de los contenidos del existencialismo, lo que lleva a considerar otros temas, como se verá a continuación, referido a la "cosificación" del ser existencial:

"Ya hemos visto antes que su tendencia a rechazar la "cosificación" de la existencia humana es compartida por otros movimientos filosóficos, inclusive por algunos que son en otros respectos declaradamente antiexistencialistas. También hay, como ha visto E. $W$. Beth, alguna relación entre el existencialismo y la crisis de la razón (cuando menos de la razón tradicional) que se ha manifestado en algunas de las direcciones de la lógica y de la filosofía matemática. Finalmente, no pueden negarse ciertos puntos de contacto entre el existencialismo y algunas manifestaciones del pragmatismo. Con las únicas filosofías con las que el existencialismo parece estar en completo desacuerdo es con el positivismo lógico, la filosofia analítica y direcciones afines. No obstante, una posibilidad de comunicación mutua no está excluida. Que tal comunicación choca con obstáculos, es evidente" (Ferrater Mora, 2004: 1978).

José Ferrater Mora presta interés a las relaciones entre escuelas, ya es parte de su método de análisis extender puentes entre corrientes opuestas o similares, ejercicio comparativo que le permitirá evidenciar la necesidad de integrar corrientes; procedimiento impensable para muchos pensadores ortodoxos. Luego avanza en su concepción:

"Walter Cerf, en «Logical Positivism and Existentialism» (...), ha señalado que los principales son: la renuncia del positivista lógico a considerar otro «horizonte» que el del "hombre como animal racional", y la renuncia del existencialista a comprender siquiera el lenguaje analítico y científico del positivista lógico. Tales obstáculos podrían, con todo, reducirse si: (a) el existencialista abandonara su tendencia a lo irracional, evocativo y emotivo, y (b) el positivista lógico comprendiera que su análisis se basa en una previa decisión que, corno tal, es de carácter "existencial"." (Ferrater Mora, 2004: 1178).

A partir de aquí, el filósofo establece un diálogo entre el lenguaje del positivismo lógico y el existencialismo que se distancia del cientificismo. Continuando el desarrollo de la cita anterior:

"Siendo tanto el existencialismo, en las formas descritas, como el positivismo lógico, cosas del pasado -aunque sea un pasado reciente, el problema de sí, y hasta qué punto, es posible una comunicación o, 
por lo menos, un diálogo filosófico entre existencialismo y positivismo lógico no se plantea ya. Más sentido tiene plantearse la cuestión del diálogo entre las últimas direcciones de la llamada, para abreviar, $<<$ filosofía analítica >>, y varias tendencias que en parte entroncan con el existencialismo y en parte con Heidegger." (Ferrater Mora, 2004: 1178).

Ferrater advierte sobre los lenguajes distintos dentro de las consideraciones y diversas tendencias existenciales. Incluso se hace gala del antiexistencialismo desde el positivismo lógico, pero que también acercan al existencialismo con ciertas características del pragmatismo. Ahora bien, hay un punto enunciado por Walter Cerf respecto a su obra Logical Positivism and Existentialism: Philosophy of Science, en la que se considera de acuerdo a la afirmación de José Ferrater Mora que puede haber punto de acuerdo o intermedio. Esto pudiera estar relacionado de algún modo a la filosofía integracionista, ya que éste busca conciliar sistemas opuestos, más no negar o trascender los mismos. Sin embargo, José Ferrater Mora no descarta que los pensadores existencialistas mantengan al margen sus respectivas parcelas de pensamiento.

Para continuar con el análisis sobre el existencialismo, se procederá a citar el Diccionario de filosofía de bolsillo (1999) de José Ferrater Mora, el cual tiene un desarrollo pertinente para este agregado:

"Ahora bien, es probable que ni él existencialista ni el positivista lógico acepten semejante entendimiento. El primero declarará seguramente o bien que el discurso meta-racional es el que él ya emplea, o bien que tal discurso tiene que someterse a supuestos que no son demostrables por medio del lenguaje científico. El segundo argüirá o bien que el discurso metaracional carece de significación o bien que no es más que un término inapropiado para designar los instrumentos de expresión descubiertos por la semiótica" (Ferrater Mora, 1999: 616).

José Ferrater Mora reiteradamente propone de cara a los resultados de sus estudios, reflexiones, lecturas y demás actividades formativas, la necesidad de conjunción según expresa entre posturas, corrientes, instrumentos, conceptos, como se leerá a continuación:

"En vista de ello, parece que lo único que cabe hacer es mostrar la efectiva conjunción parcial del existencialismo y del positivismo lógico mediante la demostración de que ambos parten de supuestos comunes, de los cuales hay unos de carácter negativo -como el hecho de rehuir como principio las doctrinas tradicionales del "ser"-, y otros de carácter positivo -como la fuerte tendencia común a aceptar el fenomenismo-. Probablemente sólo en el futuro podrá verse con suficiente claridad si se trata de dos movimientos completamente opuestos -hasta el punto de que sólo equívocamente puede incluirse a ambos dentro del campo de la filosofía-, o bien de dos distintas 
manifestaciones de supuestos comunes a la mayor parte de las doctrinas vivas de nuestro tiempo" (Ferrater Mora, 1999: 616).

Aquí el Ferrater Mora se ocupa de enderezar lo que el aprecia como desaciertos o equívocos, perturbaciones varias que han afectado el desarrollo de algunos conceptos:

"Lo que parece, en todo caso, problemático es sostener que dichas doctrinas son enteramente peculiares de ciertos países o tipos psicológicos (por ejemplo: él positivismo lógico, de los países anglosajones; el existencialismo, de Alemania o de los países latinos). Esta afirmación toma lo que sucede actualmente en filosofía por lo que ha sucedido siempre; es un caso de "presentismo" del cual no están exentos ni los existencialistas ni los positivistas lógicos" (Ferrater Mora, 1999: 616).

Considerar que tanto el existencialismo como el positivismo lógico tienden a asumir posturas absolutistas, ninguna puede negar que hay rasgos que las acercan y en la que no hay una extrema distancia, por eso José Ferrater Mora hace caso omiso a la banalización que algunos filósofos hacen de ambas tendencias del pensamiento:

"Tampoco pueden admitirse los argumentos habituales: el existencialismo es puro verbalismo y emocionalismo; el positivismo lógico es una manifestación de sequedad de espíritu. Estos últimos argumentos son más propios del lenguaje polémico que del descriptivo; es tanto más sorprendente que a ellos se hayan dejado arrastrar filósofos simpatizantes con el positivismo lógico, que se han dedicado a atacar el existencialismo a base de puros estallidos de indignación o con insistentes afirmaciones acerca del carácter superior de la ciencia. Como ha señalado A. de Waelhens en su libro sobre Heidegger, puede acusarse a este autor de muchas cosas menos de "ingenuidad" filosófica. Finalmente, es dudosa la frecuente equiparación que algunos adversarios del existencialismo hacen de esta corriente con ciertas tendencias políticas: por ejemplo, el irracionalismo totalitario. Según $F$. H. Heinemann, hay al respecto muchas diferencias entre los diversos filósofos, y lo que puede decirse de Heidegger no corresponde, por ejemplo, a Jaspers. Esta crítica política de las tendencias existencialistas es, por supuesto, tan errónea y, sobre todo, tan desencaminadora como la que algunos autores (por ejemplo, C. E. M. Joad) han hecho del positivismo lógico, condenado frecuente -y erróneamente- como conducente a una sociedad totalitaria" (Ferrater Mora, 1999: 616).

En conexión con los fragmentos ya analizados y expuestos que permiten tener una visión más clara de la posición sobre el existencialismo y la filosofía existencial en José Ferrater Mora, vuelve a retormarse que no sólo existe el existencialismo, sino también un transexistencialismo propuesto por Roberto Giordani, que además afirma que el existencialismo debe ser superado desde sus diversas corrientes, ya sea la que procede de Martin Heidegger o incluso aquella que está impregnada de la dialéctica hegeliana. 
Superación que inicia desde la apodíctica, que va de lo negativo a lo positivo absoluto en todas las esferas. Desde lo material a lo metafísico. Se observa que además de las corrientes existencialistas mencionadas, destaca que hay un existencialismo positivista.

El existencialismo es trascendente a medida que no sólo causa la aparición de sus diversas corrientes, incluso las corrientes antiexistencialistas y que desde ciertos críticos marxistas la consideran una filosofía burguesa, ya que también ciertos puntos de la filosofía existencialista se conectan con el pragmatismo. Abarca entonces desde los creyentes como el filósofo y teólogo Sören Kierkegaard, hasta profundos ateos y filosofías de carácter nihilista.

Finalmente, precisa ser mencionada aunque sea en breve representación, la filosofía de la existencia, así como el término existencia, que permite dar cierre al tema de la cosmovisión existencial. Para este punto, se toma como fuente el artículo del Diccionario de filosofía abreviado de José Ferrater Mora citado desde una fuente electrónica:

"Existencia” quiere decir "lo que está ahi”; y en este sentido es
igualable a la realidad. Hay que diferenciar la naturaleza o esencia,
de la existencia, de las distintas entidades existentes. Para Aristóteles,
la existencia es la substancia como entidad; la substancia primera,
porque es de lo que puede decirse algo y donde se encuentran las
propiedades. La existencia junto a la esencia es un ser. Solamente
podemos saber qué es algo, cuando es. Aristóteles utiliza los
conceptos de materia y forma y de potencia y acto, que constituyen las
bases para los posteriores debates filosóficos sobre la relación entre
la existencia y lo que hace que la existencia sea; es decir, la relación
entre la esencia y la existencia. Los filósofos medievales muestran
algunas diferencias básicas, entre algunas concepciones griegas,
sobre la existencia. La tendencia de los griegos es concebir la
existencia como cosa, pero la de los filósofos cristianos proponen que
hay existencias que no son cosas pero que no obstante tienen más
existencia que otros entes, por ejemplo: Dios, los seres humanos, etc.
En la filosofía medieval hay dos concepciones fundamentales sobre la
relación entre esencia y existencia: en una de ellas prima la esencia
sobre la existencia y en la que la existencia incluso se concibe como
un accidente de la esencia, por ejemplo, Avicena. En la otra prima la
existencia sobre la esencia, en la que la esencia es la inteligibilidad
de la existencia, por ejemplo, San Buenaventura, Santo Tomás, etc.
Algunas veces se equipara existencia y ser, pero surge la dificultad de
si se puede predicar de algo que existe el existir mismo. Otros autores
piensan que la existencia es el primer predicado de toda entidad
existente y todo lo demás es secundario. Significa que la existencia no
existe pero sí existen todas las demás entidades. Para Kant, la
existencia no es un predicado real como por ejemplo: es azul, es
liviano, porque decir que es un predicado es redundante. Si fuera un
atributo, las proposiciones existenciales afirmativas serían
tautologías (lo mismo repetido de distinta forma) mientras las 
proposiciones existenciales negativas serían contradicciones." (Ferrater Mora, 1970).

Es importante señalar que José Ferrater Mora expone existencia sin hacer conexión con existencial, existencialismo y filosofía de la existencia, situación que deja en evidencia que no debe en ningún caso colocar en correlación la consideración de la existencia como posible vertiente del existencialismo como corriente filosófica, para lo cual el filósofo barcelonés sigue agregando:

"Por otra parte, decir que algo es, no quiere decir que existe. El es, se refiere siempre a la forma en que es algo, porque no puede subsistir por sí mismo. Si el predicado es que algo es existente faltaría el cómo, el cuándo y el dónde de la existencia. De manera que el ser existente no tiene significado fuera de un contexto, lo que supone que el concepto que describe algo existente y el que describe algo que no existe no son conceptos distintos. En el existencialismo, la doctrina de Kierkegaard dice que la existencia es antes que nada un existente, el existente humano cuyo ser es la subjetividad, en la pura libertad de elección. No se puede hablar ni de la esencia ni siquiera de la existencia, sólo se puede hablar de "este o aquel existente", porque su verdad es la subjetividad. Existir, para Kierkegaard es tomar una decisión última relacionada con la trascendencia divina; y esa decisión determina el momento. Por esta razón la filosofía no es descripción de esencias, es decisión, afirmación de existencias. En Kierkegaard prima la existencia sobre la esencia, así como en Nietzsche, Dilthey, Bergson, Sartre y hasta en cierto sentido Heidegger, aunque todos ellos partan de supuestos distintos. Heidegger utiliza la palabra "dasein" que no significa existencia en el sentido tradicional, sino el ser hombre como el único que se pregunta por el sentido del ser; de manera que lo que distingue a esta existencia es su poder ser y no lo que ya es." (Ferrater Mora, 1970).

Se puede observar en este artículo el por qué algunos de los filósofos y académicos que tributaron al existencialismo quisieron abarcar y atribuir esa filosofía a filósofos antiguos, que más que desarrollar el existencialismo lo que hicieron fue pensar en la existencia desde diversas visiones, que nada tienen que ver con un sistema o doctrina que para los fines de esta tesis quiere establecer como cosmovisión del existencialismo. En la filosofía de la existencia se observarán a muchos autores que se identifican o fueron identificados con el existencialismo, incluyendo aquellos que afirmaron no ser existencialistas ya que sus sistemas de pensamiento abarcan territorios mucho más amplios como lo afirma José Ferrater Mora. El concepto sobre la filosofía de la existencia es tan complejo como el existencialismo, pero en sí mismo no constituye una corriente o corrientes filosóficas como el existencialismo ha demostrado ser. 
Respecto al término existencia, José Ferrater Mora hace referencia a que su profundidad debe ser analizada desde la historia de la filosofía, ya que su significado va más allá de la entidad o existencia real o ideal. Se desbordaría desde considerar la historia primaria de la filosofía griega, pasando por los clásicos de filosofía moderna y su vanguardia.

Tal situación, ubica considerar que la cosmovisión sobre el existencialismo y la filosofía existencial en José Ferrater Mora en su visión sobre el integracionismo, abarca una filosofía de la existencia, un análisis de lo existencial como parte de las realidades orgánicas e inorgánicas que dio entre sus resultados plasmar en sus primeras obras un sistema que lo distingue y le destaca en la filosofía contemporánea y universal.

\section{Tanatología y Existencia en Ferrater Mora.}

¿Y la verdad? ¿Se vive o se comprende?

Miguel de Unamuno

Para ahondar en entendimiento deberá puntualizarse en las consideraciones que giran en torno a la referencia con respecto a la tanatología, la cual en momentos también ha sido llamada "ciencia de la muerte". En relación a ella, José Ferrater Mora afirmaría que el uso del vocablo es más corriente como referencial al estudio o a los grupos de estudios, vinculados a la muerte (Ferrater Mora, 2004: 3441). De modo que resulta propia de médicos y demás profesionales del área de la salud, pese a ello, será utilizado en ocasiones ignorando su uso en oficios insertos en las ciencias sociales. La tanatología, se comprende entonces, se encarga de variadas complicaciones relacionadas al final de lo que 'existe'. Es por ello que la muerte es un tema recurrente en las filosofías de carácter existencial, ya que la muerte es una experiencia que se observa desde lo trágico, relacionada al dolor, la angustia y causa una curiosidad por lo desconocido y por eso también surgen conjeturas de orden metafísico, que vinculan la muerte con otra existencia, que hay o pudiera haber otra cosa más allá de la muerte.

$\mathrm{Al}$ ingresar en la concepción de la muerte sostiene José Ferrater Mora, iniciando por los antecedentes más remotos, que: "Platón afirmó que la filosofía es una meditación de la muerte. Toda vida filosófica, escribió después Cicerón, es una commentatio mortis" 
(2004:2472). Luego de Grecia y Roma, llega en su reconstrucción cronológica a España veinte siglos más tarde, atestiguando:

"Santayana dijo que «una buena manera de probar el calibre de una filosofía es preguntar lo que piensa acerca de la muerte». Según estas opiniones, una historia de las formas de la «meditación de la muerte» podría coincidir con una historia de la filosofía. Ahora bien, tales opiniones pueden entenderse en dos sentidos. En primer lugar, en el sentido de que la filosofía es o exclusiva o primariamente una reflexión acerca de la muerte. En segundo término, en el sentido de que la piedra de toque de numerosos sistemas filosóficos está constituida por el problema de la muerte. Sólo este segundo sentido parece plausible” (Ferrater Mora, 2004: 2472).

Desde aquí José Ferrater Mora establece firmes relaciones entre la filosofía y la muerte, hallando en la noción de muerte o cesación, un aspecto que trasciende más allá del fenómeno humano y pasa a darle espacio como noción filosófica. Continúa su exposición: "Por otro lado, la muerte puede ser entendida de dos maneras. Ante todo, de un modo ambiguo, luego, de una manera restringida. Ampliamente entendida, la muerte es la designación de todo fenómeno en el que se produce una cesación” (2004: 2472). La muerte pensada de dos modos: de un modo ambiguo, o, de un modo restringido, lo que quiere decir:
"En sentido restringido, en cambio, la muerte es considerada exclusivamente como la muerte humana. Lo habitual ha sido atenerse a este último significado, a veces por una razón puramente terminológica y a veces porque se ha considerado que sólo en la muerte humana adquiere plena significación el hecho de morir. Esto es especialmente evidente en las direcciones más «existencialistas» del pensamiento filosófico, no sólo las actuales, sino también las pasadas. En cierto modo, podría decirse que el significado de la muerte ha oscilado entre dos concepciones extremas: una que concibe el morir por analogía con la desintegración de lo inorgánico y aplica esta desintegración a la muerte del hombre, y otra, en cambio, que concibe inclusive toda cesación por analogía con la muerte humana" (Ferrater Mora, 2004: 2472).

Al seleccionar los elementos que pasan a reconstruir la formación del concepto, se hace necesario advertir: que el reconocimiento de la muerte es reconocimiento del ser en cuanto es: "Una historia de las ideas acerca de la muerte supone, en nuestra opinión, un detallado análisis de las diversas concepciones del mundo -y no sólo de las filosofíashabidas en el curso del pensamiento humano" (Ferrater Mora, 2004: 2472).

Además, sostiene Ferrater Mora junto al necesario análisis de las distintas interpretaciones del mundo, el ser y la muerte, refiere que son y deben ser planteamientos 
naturales relativos a lo existencial y que reportan un problema filosófico, sobre el sentido del ser y el sentido de la vida en conjunto:

"Supone un análisis de los problemas relativos al sentido de la vida y a la concepción de la inmortalidad, ya sea bajo la forma de su afirmación, o bien bajo el aspecto de su negación. En todos los casos, en efecto, resulta de ello una determinada idea de la muerte. Nos limitaremos aquí a señalar que una dilucidación suficientemente amplia del problema de la muerte supone un examen de todas las formas posibles de cesación aun en el caso de que, en último término, se considere como cesación en sentido auténtico solamente la muerte humana. Hemos realizado en otro lugar este examen (cfr. El sentido de la muerte, 1947, especialmente cap. I). De él resulta, por lo pronto, que hay una distinta idea del fenómeno de la cesación de acuerdo con ciertas últimas concepciones acerca de la naturaleza de la realidad" (Ferrater Mora, 2004: 2472-2473).

Lo humano no es lo único que cesa, entendiendo así que no es lo único que existe desde las concepciones filosóficas de lo que es vida. A este planteamiento José Ferrater Mora complementa otros conceptos:

"El atomismo materialista, el atomismo espiritualista, el
estructuralismo materialista y el estructuralismo espiritualista
defienden, en efecto, una diferente idea de la muerte. Ahora bien,
ninguna de estas concepciones entiende la muerte en un sentido
suficientemente amplio, justamente porque, a nuestro entender, la
muerte se dice de muchas maneras (desde la cesación hasta la muerte
humana), de tal modo que puede haber inclusive una forma de muerte
específica para cada región de la realidad. La analogía mortis que
con tal motivo se pone de relieve puede explicar por qué -para citar
casos extremos- la concepción atomista materialista es capaz de
entender el fenómeno de la cesación en lo inorgánico, pero no el
proceso de la muerte humana, mientras que la concepción
estructuralista espiritualista entiende bien el proceso de la muerte
humana, pero no el fenómeno de la cesación en lo inorgánico"
(Ferrater Mora, 2004: 2472-2473).

Aunque en apego a estas palabras, especifica a continuación pormenores sobre el sentido, que considera más aptos ante esta propuesta integracionista de su concepción de la realidad mortal, advirtiendo la verdadera sustancia formativa de esta 'cesabilidad':

"No se trata, pues, de adoptar una determinada idea del sentido de la cesación en una determinada esfera de la realidad y aplicarla por extensión a todas las demás esferas (por ejemplo, de concebir la muerte principalmente como cesación en la naturaleza inorgánica y luego de aplicar este concepto a la realidad humana; o, a la inversa, de partir de la muerte humana y luego concebir todas las demás formas de cesación como especies, por acaso «inferiores», de la muerte humana). Se trata más bien de ver de qué distintas maneras «cesan» varias formas de realidad y de intentar ver qué grados de 
"cesabilidad» hay en el continuo de la Naturaleza" (Ferrater Mora, 2004: 2472-2473).

Ante ello José Ferrater Mora se sumerge en los recovecos del 'ser', de ese ser que existe y que tiene sus propiedades o fenomenología como se puede leer a continuación:

"En El ser y la muerte (1962), el autor de la presente obra ha formulado varias proposiciones relativas a la propiedad «ser mortal», donde la expresión 'ser mortal' resume cualquier modo de dejar de ser: «1) Ser real es ser mortal; 2) Hay diversos grados de mortalidad, desde la mortalidad mínima a la máxima; 3) La mortalidad mínima es la de la naturaleza inorgánica; 4) La mortalidad máxima es la del ser humano; 5) Cada uno de los tipos, de ser incluidos en 'la realidad', es comprensible y analizable en virtud de su situación ontológica dentro de un conjunto determinado por dos tendencias contrapuestas: una que va de lo menos mortal a lo más mortal y otra que recorre la dirección inversa» (op. cit., § 9). Lo que se llama «muerte» es entendido aquí como un fenómeno, o una «propiedad», que permite "situar» tipos de entidades en el citado "continuo de la Naturaleza»" (Ferrater Mora, 2004: 2472-2473).

Sobre el problema general de la muerte, José Ferrater Mora reconoce aquí tanto los elementos pre-existentes como lo que se asoman como aportes de necesaria consideración. No obstante terminaría calificándoles como conceptos-limites, admitiendo a su vez el hecho de no poseer tal propiedad como completa:

"Ha sido común estudiar filosóficamente el problema de la muerte como problema de la muerte humana. En la actualidad abundan los estudios biológicos, psicológicos, sociológicos, médicos, legales, etc., sobre la muerte, con atención a casos concretos, a los modos como en distintas comunidades y en diferentes clases sociales se hace frente al hecho de que los seres humanos mueren. Estos estudios son importantes, porque ponen de manifiesto que la muerte humana es un fenómeno social, a la vez que un fenómeno natural. Por eso se tienen en cuenta no solamente los «moribundos» y los «fallecidos», sino también los sobrevivientes. La investigación propia a que antes nos referimos no deja de lado los citados estudios, pero atiende a la noción de «muerte» (o de «cesación») como noción general filosófica y no solamente como un fenómeno humano. En lo que toca al último se han contrapuesto dos tesis extremas: según una de ellas, la muerte es simple cesación; según la otra, la muerte es «la propia muerte», irreductible e intransferible" (Ferrater Mora, 2004: 2473).

Se expresa que la muerte es un fenómeno social, una manifestación de lo humano, por tanto está contenida dentro de lo existencial. Pero es importante la mención de que la muerte o la cesación del ser es un fenómeno natural que se expresa en la vida orgánica, incluso en la vegetal. Los seres humanos mueren, pero la muerte tiene su significado para los que 
le sobreviven, en referencia a sus deudos, ya sean familiares o personas cercanas. Para esas personas, la muerte es un tema de su existencia.

Desde la observación del fenómeno de la muerte José Ferrater Mora considera que se pueden aplicar conceptos:

“Estimamos, por nuestro lado, que la llamada «mera cesación» y la muerte «propiamente humana» funcionan a modo de conceptoslímites. De la muerte humana se puede decir que es «más propia»que otras formas de cesación, pero, a menos de cortar por completo la persona humana de sus raíces naturales, debe admitirse que tal propiedad no es nunca completa" (Ferrater Mora, 2004: 2473).

José Ferrater Mora da fin a la muerte, remitiendo a la diversidad de estudios -de las fuentes- que han desarrollado acertadas investigaciones a lo largo del tiempo, reconociendo así:

"Junto a una investigación filosófica de la muerte, puede procederse a una descripción y análisis de las diversas ideas que se han tenido acerca de la muerte en el curso de la historia, y en particular en el curso de la historia de la filosofía. Puede entonces examinarse la idea de la muerte en el naturalismo, en el estoicismo, en el platonismo, en el cristianismo, etc. También pueden estudiarse las diversas ideas de la muerte en diversos "círculos culturales» o en varios períodos históricos. En la mayor parte de los casos este estudio va ligado a un examen de las diversas ideas acerca de la supervivencia y la inmortalidad" (Ferrater Mora, 2004: 2473).

La mención de las diversas ideas de la muerte a lo largo de la historia y en este caso en la historia de la filosofía, el pensador catalán expresa que esas ideas también se desarrollan en círculos culturales. La cultura como hecho existencial que desde su accionar evoca nociones y estudios sobre temas más allá de la muerte, como la supervivencia y la inmortalidad, que son del contexto existencial.

En textos como El hombre y la muerte (1970) José Ferrater Mora va tejiendo la significación existencial de la muerte, en El sentido de la muerte (1947) se posiciona el sentido de la vida y ésta, finalmente, brinda sentido al ser. Diversos textos en forma de artículos enlazados a sus lectores en general, como a sus vinculaciones al ámbito universitario que desde su largo hospedaje en los Estados Unidos de América le sirvieron para la mejor propagación de sus ideas.

En muchas de estas reflexiones de naturaleza existencial, un problema de todos se aborda en correspondencia a ese carácter irrenunciable, la metafísica como la ontología son aplicadas sobre el individuo, como problema indivisible y natural, es como reza el titulo 
ferrateriano El hombre y la muerte, el hombre y sus pasos hacia la muerte, donde el eco de este encuentro permite un boceto en continua construcción sobre el problema de ser sujeto, todo sujetado a la muerte desde lo existencial y enteramente humano.

El término inmortalidad, no escapa a esta discusión, pues rebasa en antigüedad al concepto de hombre moderno y su mortalidad. Reflexiones en vida sobre la expiración, artículos de interdisciplinarios intelectuales que establecen este dialogo analítico, seriamente cruzado entre varios autores en amplitud de número y pensamiento; filosofía profunda y delicada, la tocante a la muerte; metafísica en un todo personal y existencial.

Antropología de la muerte, metafísica y ontológicamente hablando, la problemática filosófica de la muerte, el ser en su respuesta siempre aproximada, se precisa la muerte como conjunto de la evolución biológica, responsabilidad ante el final; problemas todos, donde la amplitud del enciclopedista permite exponer las principales conclusiones de brillantes estudiosos e intelectuales, que a su vez han venido recabando, compilando las más variadas aportaciones del ser humano y su insaciable sed de comprensión un intrincado ir y venir, existir, pensando cada vez más claramente sobre la muerte y su inferencia en lo existencial.

El hombre ante la muerte, plasma a la muerte como ese espectador permanente, desde la vida, espectadores existenciales dan forma a esta presencia, que cuestiona cada día más cerca, acerca de la naturaleza humana y sus escasas posibilidades de supervivencia personal, la filosofía de la muerte es la evidencia de la vida, enriquecida en un después de la muerte, lo que contempla la metafísica de la muerte, naturaleza de la vida, sentido del ser.

Ha aportado José Ferrater Mora una amplia bibliografía, sobre la muerte, lo existencial y temas vecinos a éste. En profundidad por su variedad, similar al texto sobre muerte, que le dedicara el barcelonés a lo largo de la entrada correspondiente a dicho concepto en su Diccionario de filosofía. Comparable al acceso hacia un enorme almacén el tema en cuestión-, resulta la lectura de estas páginas, donde las posibilidades de riqueza contenidas en la obra ferrateriana se reconocen a simple vista; pues a dónde este excelente guía dirige el viaje, en este caso a las profundidades históricas y de la historia de la filosofía, sobre el fin de la vida humana y sus existencia, como ejemplo paradigmático de la implicación del ser mortal, es decir, del ser que cesa, posibilidad no exclusiva del ser humano sino de todo cuanto posee existencia y que no poseen desperdicio. 
José Ferrater Mora en lo tocante a la muerte aprehende sus meditaciones en distintas direcciones; una de estas es el sentido biológico, sintetizando en él muchas de ellas y ampliando un poco las de mayor interés, para continuar incorporando herramientas que le permitiesen robustecer, tanto su trayectoria profesional como enciclopedista, como para su postura filosófica existencial, o un poco más adelante ante su proyecto integracionista. Las investigaciones sobre el llamado 'problema de la inmortalidad de la célula', la disputa contra la muerte, haciendo referencia a investigaciones sobre fisiología, las contrariedades entre la vida y la muerte, la ética médica, el cerebro, los criterios de la bioética, el angustioso fin de la vida. Finalmente otro gran estudio y análisis de conceptos desde su bien afinada observación filosófica.

Sobre las complicadas relaciones entre el envejecimiento y la muerte, José Ferrater Mora presta peculiar atención a dicha cuestión, sabiendo además que son tópicos abordados por las filosofías de carácter existencial, deteniendo su estudio obsequioso a las complejidades éticas, biológicas y médicas.

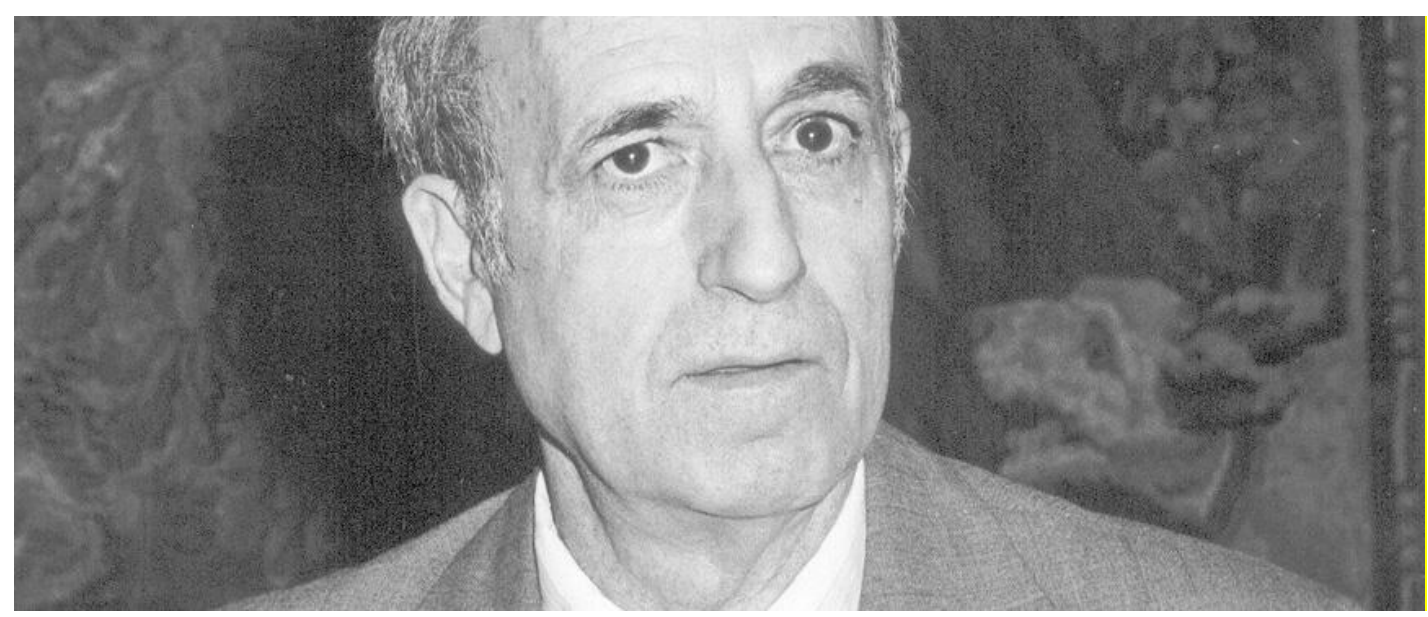

Ilustración 16: José Ferrater Mora Premio Príncipe de Asturias de Comunicación y Humanidades 1985. (Fuente: Fundación Princesa de Asturias - reseña de premios. Tomado de: http://www.fpa.es/es/premiosprincesa-de-asturias/premiados/1985-jose-ferrater-mora.html?texto=acta\&especifica=0).

En José Ferrater Mora el problema de la muerte es observado con la integridad metodológica acostumbrada en el pensador, reflexionando sobre diversas culturas, épocas $\mathrm{y}$ autores, partiendo de los griegos y romanos, para luego incorporar al dialogo a ejemplares aportes de autores ya clásicos, como las realizaciones de Epicuro, Miguel de Unamuno -fundamentalmente con el ensayo filosófico: Del sentimiento trágico de la vida 
(1913)-, Karl Jaspers, Jean-Paul Sartre, Carlos Marx, Martin Heidegger; llegando de este modo a autores más inmediatos como por ejemplo Sigmund Freud o Jean Jacques Lacan.

Para continuar profundizando en la tanatología ferrateriana y sus implicaciones con lo existencial se analizará el concepto de muerte desde la perspectiva integracionista.

\subsection{Muerte e inmortalidad: la ilusión integracionista.}

La muerte es un tema que plantea un lugar común en la filosofía, especialmente en el existencialismo. Desde Sören Kierkegaard, pasando por Miguel de Unamuno, Jean-Paul Sartre, también José Ortega y Gasset y Albert Camus (en su planteamiento sobre el absurdismo y el suicidio en El mito de Sísifo).

En José Ferrater Mora es un tema imprescindible, un tópico que nutre de manera significativa su sistema filosófico. Es fácil darse cuenta de ello en su concepto sobre la muerte plasmado en el Diccionario de filosofía:

\section{“MUERTE.}

Platón afirmó que la filosofía es una meditación de la muerte. Toda vida filosófica, escribió después Cicerón, es una commentatio mortis. Veinte siglos después Santayana dijo que «una buena manera de probar el calibre de una filosofía es preguntar lo que piensa acerca de la muerte». Según estas opiniones, una historia de las formas de la «meditación de la muerte» podría coincidir con una historia de la filosofía. Ahora bien, tales opiniones pueden entenderse en dos sentidos. En primer lugar, en el sentido de que la filosofía es o exclusiva o primariamente una reflexión acerca de la muerte. En segundo término, en el sentido de que la piedra de toque de numerosos sistemas filosóficos está constituida por el problema de la muerte. Sólo este segundo sentido parece plausible." (Ferrater Mora, 2004: 2472).

En el empirismo dialéctico tanto la muerte como la inmortalidad son equivalentes de ilusión. Ya Platón había discurrido sobre la primera, considerando el amor a la sabiduría como una meditación con la muerte. Este planteamiento ya constituye en sí una comparación integracionista.

Por eso, el pensador catalán se plantea el concepto de la muerte en dos direcciones o dos maneras:

"Por otro lado, la muerte puede ser entendida de dos maneras. Ante todo, de un modo ambiguo, luego, de una manera restringida. Ampliamente entendida, la muerte es la designación de todo 
fenómeno en el que se produce una cesación. En sentido restringido, en cambio, la muerte es considerada exclusivamente como la muerte humana. Lo habitual ha sido atenerse a este último significado, a veces por una razón puramente terminológica y a veces porque se ha considerado que sólo en la muerte humana adquiere plena significación el hecho de morir. Esto es especialmente evidente en las direcciones más «existencialistas» del pensamiento filosófico, no sólo las actuales, sino también las pasadas. En cierto modo, podría decirse que el significado de la muerte ha oscilado entre dos concepciones extremas: una que concibe el morir por analogía con la desintegración de lo inorgánico y aplica esta desintegración a la muerte del hombre, y otra, en cambio, que concibe inclusive toda cesación por analogía con la muerte humana. " (Ferrater Mora, 2004: 2473).

Precisamente es la muerte la que da vida al integracionismo porque en su tema se encuentran "concepciones extremas". Y esas concepciones no solo obedecen a la epistemológico, terminológico y las diversas indagaciones sobre el lenguaje. Obedece a conceptos que trascienden la muerte humana, ya que incluso puede hablarse de la muerte de un pensamiento o doctrina o la muerte de un objeto inanimado (ejemplo, las caseteras han muerto, ya no se usan) o que la modernidad ha muerto por el surgimiento de la posmodernidad.

Ahora bien. ¿Qué supone en el propio José Ferrater Mora su opinión y consideración en torno a las ideas de la muerte? El autor responde:

"Una historia de las ideas acerca de la muerte supone, en nuestra opinión, un detallado análisis de las diversas concepciones del mundo -y no sólo de las filosofías- habidas en el curso del pensamiento humano. Además, supone un análisis de los problemas relativos al sentido de la vida y a la concepción de la inmortalidad, ya sea bajo la forma de su afirmación, o bien bajo el aspecto de su negación. En todos los casos, en efecto, resulta de ello una determinada idea de la muerte. Nos limitaremos aquí a señalar que una dilucidación suficientemente amplia del problema de la muerte supone un examen de todas las formas posibles de cesación aun en el caso de que, en último término, se considere como cesación en sentido auténtico. Solamente la muerte humana. Hemos realizado en otro lugar este examen (cfr. El sentido de la muerte, 1947, especialmente cap. I). De él resulta, por lo pronto, que hay una distinta idea del fenómeno de la cesación de acuerdo con ciertas últimas concepciones acerca de la naturaleza de la realidad. El atomismo materialista, el atomismo espiritualista, el estructuralismo materialista y el estructuralismo espiritualista defienden, en efecto, una diferente idea de la muerte." (Ferrater Mora, 2004: 2472, 2473).

Atendiendo precisamente a su primera obra que marcará el camino inicial del integracionismo, el primer capítulo de El sentido de la muerte demarca una concepción 
fenomenológica distante de las visiones materialistas, espiritualistas, estructuralistas, pero sin embargo no hace mención específica de las ideas existenciales en el tema expuesto. Con respecto a esas visiones enunciadas por José Ferrater Mora, el pensador catalán afirma la falta de integralidad (una visión menos amplia) de las ideas de la muerte contenidas en la previa historia de la filosofía:

\begin{abstract}
"Ahora bien, ninguna de estas concepciones entiende la muerte en un sentido suficientemente amplio, justamente porque, a nuestro entender, la muerte se dice de muchas maneras (desde la cesación hasta la muerte humana), de tal modo que puede haber inclusive una forma de muerte específica para cada región de la realidad. La analogía mortis que con tal motivo se pone de relieve puede explicar por qué -para citar casos extremos- la concepción atomista materialista es capaz de entender el fenómeno de la cesación en lo inorgánico, pero no el proceso de la muerte humana, mientras que la concepción estructuralista espiritualista entiende bien el proceso de la muerte humana, pero no el fenómeno de la cesación en lo inorgánico." (Ferrater Mora, 2004: 2473).
\end{abstract}

Como lo indica el intelectual, la muerte no es una sola cosa, la muerte no corresponde solo a una situación de la vida humana, sino que supera fenómenos orgánicos e inorgánicos. Es así como José Ferrater Mora impulsa su sistema filosófico de integrar ideas opuestas, concepciones antagónicas con respecto a la muerte, ideas que encierran un grado de dogmatismo o reduccionismo. El empirismo dialéctico está en la búsqueda de "tender puentes" en la percepción de una temática que forma una constante en la existencia.

Son estas ideas la que dan estructura funcional, sobre todo para los fines del integracionismo, en el sentido común de estudio filosófico del fenómeno de la muerte:

"No se trata, pues, de adoptar una determinada idea del sentido de la cesación en una determinada esfera de la realidad y aplicarla por extensión a todas las demás esferas (por ejemplo, de concebir la muerte principalmente como cesación en la naturaleza inorgánica y luego de aplicar este concepto a la realidad humana; o, a la inversa, de partir de la muerte humana y luego concebir todas las demás formas de cesación como especies, por acaso «inferiores», de la muerte humana). Se trata más bien de ver de qué distintas maneras «cesan» varias formas de realidad y de intentar ver qué grados de «cesabilidad» hay en el continuo de la Naturaleza." (Ferrater Mora, 2004: 2473).

Como es usual en José Ferrater Mora, cada realidad corresponde a una concepción particular. Por eso, la muerte no es un concepto único sino diverso, debido a las diversas esferas del quehacer humano y existencial, pero sin dejar a un lado al resto de las especies 
existentes en la naturaleza, que incluso puede poseer sus particularidades en distintos "grados" o maneras de muerte.

Esto lleva a considerar que la muerte tiene sus "propiedades" inherentes a sus procesos, como lo indica José Ferrater Mora:

"En El ser y la muerte (1962), el autor de la presente obra ha formulado varias proposiciones relativas a la propiedad «ser mortal», donde la expresión 'ser mortal' resume cualquier modo de dejar de ser: «1) Ser real es ser mortal; 2) Hay diversos grados de mortalidad, desde la mortalidad mínima a la máxima; 3) La mortalidad mínima es la de la naturaleza inorgánica; 4) La mortalidad máxima es la del ser humano; 5) Cada uno de los tipos, de ser incluidos en 'la realidad', es comprensible y analizable en virtud de su situación ontológica dentro de un conjunto determinado por dos tendencias contrapuestas: una que va de lo menos mortal a lo más mortal y otra que recorre la dirección inversa» (op. cit., §9). Lo que se llama «muerte» es entendido aquí como un fenómeno, o una «propiedad», que permite «situar» tipos de entidades en el citado «continuo de la Naturaleza»." (Ferrater Mora, 2004: 2473).

En las proposiciones enunciadas por José Ferrater Mora, corresponde a la visión evolucionada que registra El ser y la muerte (continuación de El sentido de la muerte), son cinco las ideas que engloban una visión amplia, integral desde una propuesta metodológica en la que "ser mortal" en correspondencia al ser humano es la máxima expresión de los grados de mortalidad. Y es desde el desarrollo de la integralidad del concepto en la que el escritor sigue exponiendo la importancia de la muerte en la existencia humana:

"Ha sido común estudiar filosóficamente el problema de la muerte como problema de la muerte humana. En la actualidad abundan los estudios biológicos, psicológicos, sociológicos, médicos, legales, etc., sobre la muerte, con atención a casos concretos, a los modos como en distintas comunidades y en diferentes clases sociales se hace frente al hecho de que los seres humanos mueren. Estos estudios son importantes, porque ponen de manifiesto que la muerte humana es un fenómeno social, a la vez que un fenómeno natural. Por eso se tienen en cuenta no solamente los «moribundos»y los «fallecidos», sino también los sobrevivientes. La investigación propia a que antes nos referimos no deja de lado los citados estudios, pero atiende a la noción de «muerte» (o de «cesación») como noción general filosófica y no solamente como un fenómeno humano. En lo que toca al último se han contrapuesto dos tesis extremas: según una de ellas, la muerte es simple cesación; según la otra, la muerte es «la propia muerte», irreductible e intransferible. Estimamos, por nuestro lado, que la llamada «mera cesación» y la muerte «propiamente humana» funcionan a modo de conceptos-límites. De la muerte humana se puede decir que es «más propia» que otras formas de cesación, pero, a menos de cortar por completo la persona humana de sus raíces 
naturales, debe admitirse que tal propiedad no es nunca completa" (Ferrater Mora, 2004: 2473).

Una de las claves expuestas es que no solo la filosofía ha hecho un estudio del fenómeno de la muerte, sino que además diversas ramas del saber humano, desde las ciencias sociales hasta la medicina y asuntos legales. Por esta razón no debería la muerte tratarse en sentidos absolutistas, sino que debe hacer un carácter amplio en las dilucidaciones de la muerte:

"Junto a una investigación filosófica de la muerte, puede procederse a una descripción y análisis de las diversas ideas que se han tenido acerca de la muerte en el curso de la historia, y en particular en el curso de la historia de la filosofía. Puede entonces examinarse la idea de la muerte en el naturalismo, en el estoicismo, en el platonismo, en el cristianismo, etc. También pueden estudiarse las diversas ideas de la muerte en diversos «círculos culturales» o en varios períodos históricos. En la mayor parte de los casos este estudio va ligado a un examen de las diversas ideas acerca de la supervivencia y la inmortalidad." (Ferrater Mora, 2004: 2473).

Las diversas ideas que se han venido tejiendo sobre tal tópico, son capaces de coexistir armoniosamente en el territorio integracionista, señala José Ferrater Mora "puede entonces examinarse la idea de la muerte en el naturalismo, en el estoicismo, en el platonismo, en el cristianismo, etc." (Ferrater Mora, 2004:2473). Ilusión llevada a cabo desde la peculiar rigurosidad de este método filosófico:

"El tipo de filosofía propuesto no consiste simplemente en negar las oposiciones para buscar un tercer término que las supere o en eludirlas para buscar una posición intermedia equidistante. Rasgo característico del integracionismo es tratar de aunar los polos antedichos -y las concepciones correspondientes a ellos- mediante el paso constante del uno al otro. El integracionismo considera, en efecto, que esta es la única posibilidad ofrecida a un pensamiento que pretenda efectivamente morder sobre lo real en vez de evitarlo o de inventar realidades supuestamente trascendentes sólo expresables por medio de otros tantos conceptos-límites" (Ferrater Mora, 2004: 1866).

Considerando que la muerte ha sido un tema desarrollado en una peculiar parte de la obra de José Ferrater Mora, se hace pertinente abordar el tema de la inmortalidad. Sobre todo por el componente dialéctico que posee el integracionismo, que si bien no concluye en determinaciones absolutas, al menos hace las comparaciones debidas en los conceptoslímites. Tal y como se ha venido aplicando en el presente trabajo, es imperante analizar el concepto de inmortalidad que el pensador catalán elaboró en su Diccionario de filosofía: 


\section{“INMORTALIDAD.}

El problema de la inmortalidad equivale a la cuestión del destino de la existencia después de la muerte, es decir, al de la supervivencia de tal existencia. Muchas respuestas se han dado al problema por parte de las diversas religiones, filosofías y concepciones del mundo. (Ferrater Mora, 2004: 1849).

Es así como José Ferrater Mora plantea el concepto, como un problema filosófico amplio, lleno de respuestas, de concepciones, incluyendo las culturas que el mundo occidental considera primitivas. Sin embargo, a lo largo del desarrollo del concepto, hace más alusión a las consideraciones que Platón emitió, incluso, expresando que es poco lo que él expone por lo denso y prolífico que fue Platón al hablar de la inmortalidad y del alma:

La concepción de Platón antes aludida es clara: hay una vida después de la muerte. Esta vida no es la semi-existencia en el pálido reino de las «sombras», sino una existencia más plena, sobre todo cuando el alma ha sido purificada. La reencarnación puede, pues, ser necesaria, pero tiene un término: el que alcanza el alma cuando reposa en su verdadero reino, que para algunos es el de las ideas, para otros el de los astros y para otros el de los espiritus puros." (Ferrater Mora, 2004: 1850).

Las ideas de Platón respecto a la inmortalidad pueden estar presente en el integracionismo, no como una verdad sobre la cual José Ferrater Mora profesa adhesión (como si es el caso de Miguel de Unamuno, que considera la inmortalidad una necesidad vital), sino sobre la cual considerar como tema para exponer. Ocurre que el pensador catalán hace una comparación conceptual en referencia a la inmortalidad con Immanuel Kant como se verá a continuación:

"Kant ha proclamado que la razón teórica o especulativa es incapaz de proporcionar ninguna «prueba» y que, en general, no hay pruebas o argumentos decisivos en favor de la inmortalidad, sean racionales o empíricos, podemos tener una certidumbre moral de que somos inmortales, pero no una lógica." (Ferrater Mora, 2004: 1852).

Considerando que la concepción de inmortalidad en Immanuel Kant no está cercana a los elementos platónicos e inclusive los aristotélicos, José Ferrater Mora sigue considerando que la posición de Kant es en ningún modo extrema:

"Ahora bien, que no haya tales pruebas -o que las llamadas tales no lo sean propiamente- no significa, según Kant, que el alma no sea inmortal; sólo ocurre que lo es por «motivos» muy distintos de los que suelen aducir las pruebas o los argumentos: porque la inmortalidad es un postulado de la razón práctica (Kant) o porque es 
un resultado del «hambre de inmortalidad» (Unamuno)." (Ferrater Mora, 2004: 1852).

Considerando algo ya expuesto: José Ferrater Mora reconoce la influencia que ejerce Kant en su pensamiento, finalmente considera una filiación entre el pensamiento kantiano y el unamuniano que es reconocido como existencialista. Nuevamente el filósofo aplica su premisa de acercar formas de pensamiento que pueden considerarse antagónicas y el resultado es que hay tópicos donde se tienden puentes. La visión de Kant respecto a Platón es distinta, pero la forma en cómo Miguel de Unamuno concibe la inmortalidad está cercana a Kant y por supuesto a Sören Kierkegaard. Son elementos existencialistas presentes en la elaboración de un concepto que es indefectible a temas como el ser y la muerte.

En los análisis de la obra de José Ferrater Mora se encuentra que en El ser y la muerte: bosquejo de una filosofía integracionista (1962) a diferencia de en El sentido de la mиerte, el concepto central era el de muerte, ahora lo es el de ser, pues el problema de la muerte exige tratar las cuestiones acerca del ser, sentido, existencia, esencia, persona o valor. Por ello, supone José Ferrater Mora, hay que desarrollar una ontología del ser real subordinada a una ontología del ser mortal. Aunque el título El ser y la muerte, denota cierta influencia existencial, ésta no es decisiva en su contenido, pero muestra de manera categórica elementos existenciales por los sistemas de pensamiento a los que hace comparaciones y análisis.

Sostiene Carlos Nieto Blanco (1985: 42) que en la ontología de José Ferrater Mora, ser real es igual a ser mortal, aunque mortal se entiende como cualquier modo de dejar de ser o de cesación. La muerte se dice de muchas maneras, con lo que en lugar de una analogía entis se tendrá una analogía mortis.

Muchas filosofías, a causa de tener una concepción de la realidad limitada, no han entendido que la muerte tiene un sentido amplio, a lo que José Ferrater Mora responde proponiendo un método -el integracionismo- que prescinde de entidades absolutas como «naturaleza», «espíritu», «objeto»o «conciencia», para dejar paso al uso de conceptoslímite opuestos pero complementarios. A cada modo de realidad le corresponde un modo de ser mortal y, aunque la muerte humana es la forma máxima de mortalidad, la noción de muerte no queda circunscrita a ella. 
Existe una gradación de mortalidad; de la mínima a la máxima: inorgánica, orgánica y humana; y la muerte es la propiedad que sitúa tipos de identidades dentro del continuo de la naturaleza. Aplicando aquí su método integracionista, José Ferrater Mora defiende la existencia de un continuo como el resultado de dos direcciones inversas pero complementarias: lo externo y lo íntimo. Estos son conceptos-límite a los que las cosas tienden, pero en sí mismos son absolutos inalcanzables.

En lo inorgánico se localiza la máxima exterioridad, por lo que el morir de las cosas físicas es más bien una cesación o muerte mínima. En lo orgánico aumenta la intimidad y, con ella, la individualidad, de modo que morir es más propio cuanto mayor es la intimidad y la individualidad. En el hombre se alcanza en grado máximo la individualidad interiorizada y en él la muerte se da como algo propio y constitutivo de su ser, ya que alcanza lo más íntimo. La muerte pertenece al hombre antológicamente, porque en él llega a lo más interior y da sentido a toda su vida.

En el hombre culmina la analogía mortis, pues en él se llega a la plenitud del hecho de morir. Aunque la muerte no da su ser a la vida humana, sí le da su ser en cuanto sentido, pues, en cuanto potencial, pasa a ser un factor decisivo de nuestra vida; la muerte carece de sentido, pero lo otorga a la vida.

La muerte como concepto está ligada íntimamente al ser. El ser se concibe como una entidad finita, que va transformándose desde su nacimiento y luego de su posterior desarrollo alcanza la cesación. Pero al ser lo rodean otras realidades inherentes a la naturaleza, a lo orgánico e inorgánico, a la materia y la razón. Razones éstas que llevaron a considerar a Carlos Nieto Blanco respecto a José Ferrater Mora ubicándolo en el perfil de una filosofía en la encrucijada, aportes que José Ferrater Mora hace desde su cosmovisión sobre el existencialismo y la filosofía existencial, sus consideraciones no solo en el campo de lo filosófico, sino desde lo enteramente humano.

\section{Existencia y libertad.}

Los elementos existencialistas o existenciales en el pensamiento de José Ferrater Mora pueden estar insertos en su método o sistema filosófico. Se analizan y se hace una lectura de su obra donde se destacan esos elementos, al igual como se expone en este apartado. En este caso, es posible detectar si hay alguna corriente o bloque específico 
dentro del existencialismo donde se pueda orientar las ideas de José Ferrater Mora en el ámbito existencial.

Si bien es cierto que es sumamente complejo establecer una definición concreta sobre lo que es el existencialismo, incluso sobre lo existencial, especialistas como André Comte-Sponville y Jacques Maritain han hecho propuestas. ¿Qué dice el filósofo francés Comte-Sponville? En su Diccionario filosófico hay una respuesta:

"Toda filosofía que toma como punto d partida la existencia individual, y no el ser o el concepto (en este sentido, Pascal o Kierkegaard se consideran, a menudo, como los precursores del existencialismo), y especialmente, según la fórmula de Jean-Paul Sartre, toda doctrina según la cual «la existencia precede la esencia». ¿Qué quiere decir? Que el hombre no posee de antemano una esencia que le preexista y de la que estaría prisionero, sino que existe «antes de poder ser definido por ningún concepto» y que sólo será (cuando se pueda hablar de su esencia en pasado) lo que haya elegido ser". (Comte-Sponville, 2003: 214)".

André Comte-Sponville, a pesar de que su idea en cierto modo trata en lo posible de establecer una forma concreta de dar una caracterización del existencialismo, ocurre que sigue siendo muy amplia y no logra posicionar una concepción definitiva. Quizás porque el existencialismo no puede sintetizarse en una caracterización reduccionista, debido a lo complejo que resultan en sí las ideas de todos los pensadores que son tributarios de esta corriente filosófica. Razón para que el filósofo francés siga ampliando su idea:

"Es decir, que es absolutamente libre: "Qué es lo que significa que la existencia preceda la esencia? Significa que, en primer lugar, existe el hombre, se encuentra, surge en el mundo y, después, se define. Si el hombre, tal como lo concibe el existencialismo, no es definible es porque, en primer lugar, no es nada. Sólo será más adelante, y será tal como él se haya hecho. Por eso, no existe la naturaleza humana, puesto que no hay Dios que pueda concebirla.[...] El hombre no es otra cosa que lo que hace consigo mismo» (El existencialismo es un humanismo). Por eso el existencialismo es una filosofía de la libertad, en el sentido metafísico del término, y una de las más radicales que se haya dado nunca". (Comte-Sponville, 2003: 214).

Teniendo en cuenta la premisa de Jean-Paul Sartre a la que hace referencia André Comte-Sponville, el existencialismo es una condición de libertad, que de algún modo el existencialismo es equivalente a tener plena consciencia de lo que se es y de su propia existencia o situación existencial. De igual manera hay referencia a que no es definible el existencialismo salvo cuando el hombre es consciente de lo que hace consigo mismo. En el existencialismo de Jean-Paul Sartre, se existe por lo que se hace, eso es lo que define al ser 
humano, el existencialismo es un humanismo porque permite que el hombre deje de ser un ser abstracto y sea en sí un ser consciente con sus respectivas dinámicas y acciones. Volviendo a Jean-Paul Sartre, el hombre es libre porque no está sujeto en su acción a la creación de un Dios que le da el destino, sino que el hombre al tener libertad es quien rige y forja su destino. Ahora bien, tomando en consideración que el hombre tiene la capacidad de ser libre una vez que toma consciencia de sí mismo y no sujeto a una esencia que le da razón de existir, André Comte-Sponville sigue desarrollando su tesis sobre lo existencial:

"Falta aún por saber si podemos hacerla nuestra. ¿Cómo existir, cómo hacer o elegir cualquier cosa, cómo inventarse o proyectarse antes de ser algo o alguien? ¿Quién diría de un recién nacido que no es nada? ¿Y cómo pensar que el hecho de ser lo que se es sea sólo una situación, que tendríamos la misión de trascender, y no, al menos en parte, una determinación, de la que se excluye que podamos salir nunca (ya que cambiar es siempre cambiarse)? "Cada persona es una elección absoluta de sí mismo», escribe Sartre en El ser y la nada; es lo que yo nunca he podido creer ni pensar. ¿Cómo elegir sin ser previamente? O más bien, qué sentido tiene distinguir, en el presente, entre lo que yo hago o quiero y lo que soy? Existir es ser en acto y situación: la esencia y la existencia, en el presente, son una sola y misma cosa". (Comte-Sponville, 2003: 214).

De acuerdo a las consideraciones de Jean-Paul Sartre que están enunciadas, al nacer no hay plena consciencia de lo que se es. Eso quiere decir que es una existencia no definida, no categorizada. Pero, ese nacimiento luego dará un giro, respecto a las experiencias, vivencias y conocimientos que se van adquiriendo, lograr la "misión de trascender". Esa misión se vuelve una determinación que puede tener rasgos marcados por la situación del ser, pero desde la cual se toma una elección o determinadas elecciones basadas en decisiones.

Cada persona, aunque haya recibido una formación de tipo conductista y que su cosmovisión esté en interacciones con el entorno que solo conoce, tiene la capacidad de decidir aunque el medio en el que se desenvuelva lo obligue a ciertas cosas. Incluso aquellas convenciones sociales en las que cualquier ser está obligado a obedecerlas (por ejemplo, aunque un hombre o mujer quiera estar desnudo en medio de una ciudad occidental, hay normas, reglas o leyes que no lo permiten) puede luego adaptarse para hacer un cambio de situación, que de seguro lo harán tomar una decisión que se acerque a su visión de libertad.

Se puede nacer católico, ya que en una sociedad o comunidad católica simplemente la conversión ocurre cuando los padres deciden bautizar al niño o niña. Luego viene la 
primera comunión y la confirmación, que a pesar de que se realiza durante la niñez, forma parte de una decisión propia, de una opción autónoma, aunque se debe reconocer que hay parámetros para un niño de 8 o 10 años en los que su entorno lo obligan a tomar esa decisión por él. Pero más allá de la niñez, ese hombre o mujer tomará la decisión de seguir bajo los valores y prácticas que le exige la iglesia católica de acuerdo a su decisión o libre albedrío. Entonces no se es católico o protestante o musulmán por nacimiento, sino por decisión, una decisión que puede ser condicionada, pero en ningún caso obligada per se.

Nacer está condicionado a decisiones que un ser humano no determina, ya que vivir en los primeros años es una dependencia obligada, los padres conducen la sobrevivencia de acuerdo a su formación, instinto y valores obtenidos. Esos factores están siendo transmitidos al niño o niña, que luego formarán parte de su carácter. Pero también son su esencia, ya que las especies y su supervivencia están condicionadas a leyes y factores que pueden o no considerarse naturales, sujetos a los cambios de entorno y situación que estén bajo la condición física. Pero el tema de la existencia o consciencia de la misma es la consideración de la libertad de ser, de elegir, de trascender.

André Comte-Sponville sigue dando argumentos sobre el significado del existencialismo amparado bajo la senda de Jean-Paul Sartre:

"Desde luego, no es así como lo vivimos o imaginamos: tenemos el sentimiento de ser lo que el pasado ha hecho de nosotros, y de elegir lo que haremos con el porvenir. "La esencia es lo que ha sido", escribe Sartre en El ser y la nada; la existencia, al contrario, es lo que no es todavía, lo que se lanza hacia el futuro, lo que será, si yo lo quiero o lo hago. "La libertad huye hacia el futuro, se define por el fin que ella proyecta, es decir, por el futuro que ella tiene que ser» (...). Pero esta distinción, entre la esencia y la existencia, sólo tiene sentido entonces para la conciencia, que se da un pasado y un porvenir, y no para lo real mismo, que sólo existe en presente, y del que la conciencia, lo quiera o no, forma parte. Un recuerdo solo existe en el presente. Un proyecto solo existe en el presente." (Comte-Sponville, 2003: 214).

Al tomar en cuenta lo expuesto por Jean-Paul Sartre, el existencialismo no es algo que se describa materialmente ni que se pueda palpar con el tacto o con el resto de los sentidos de orden biológico. Más bien lo caracteriza lo que no puede percibirse en estado presente salvo ser proyectado o recordado. El pasado y el porvenir van de lo esencial a lo existencial. Es esencial porque se recuerda. Es existencial porque se proyecta. En el caso de Kierkegaard, la angustia puede considerarse una proyección, basada en un creo o dogma. La angustia por saber si se va o no al cielo, la angustia por el destino y voluntad divina, 
sobre todo si esa angustia viene causada por el pecado o por la facultad de asumir el libre albedrío. Esto lleva considerar que hay un elemento imaginario en la concepción existencialista de la vida, el existencialismo es imaginación o idea de lo que se era y lo que será. Es una paradoja de acuerdo a lo que interpreta André Comte-Sponville y expone a continuación:

\begin{abstract}
“¿Y cómo podría el presente no ser lo que es o ser diferente? Sartre, coherentemente, explica que la libertad sólo es posible como nada, no como ser, lo que siempre me ha parecido una refutación suficiente: la libertad, en este sentido absoluto, sólo es posible a condición de no ser. El existencialismo no es más que un humanismo imaginario. ¿Es necesario entonces volver a caer en un existencialismo que nos encerraría para siempre en lo que somos, por lo cual la existencia no sería más que un efecto de la esencia? De ninguna manera. En el presente, la esencia y la existencia se confunden, y no podrían precederse mutuamente. $\mathrm{Ni}$ existencialismo, pues, $\mathrm{ni}$ esencialismo: la existencia no precede a la esencia, del mismo modo que la esencia no precede a la existencia. Sólo existen juntas, en un mismo mundo, en un mismo presente, y eso es lo que significa existir". (Comte-Sponville, 2003: 214, 215).
\end{abstract}

De acuerdo a lo dispuesto por Comte-Sponville, Jean-Paul Sartre expuso un existencialismo equivalente a un humanismo imaginario. Un existencialismo que pareciera estar enmarcado en una contradicción, un problema no resuelto y que esa libertad que se persigue en la existencia se alcanza fuera de ella. Sin embargo hay una situación expuesta en torno a la esencia: no hay una negación de lo existencial por lo esencial. Dicho de otro modo, la esencia y la existencia son un conjunto que tiene sentido en comunión total. Ni la esencia precede a la existencia ni viceversa. Más bien son un conjunto dialéctico, que conlleva a considerar que no hay un esencialismo separado del existencialismo, son parte indivisibles, aunque tengan elementos de particularidad o singularidad, que en todo caso se complementan.

Teniendo en cuenta este análisis, su visión está condicionada básicamente en las propuestas de Jean-Paul Sartre y su definición toma poca consideración por otras visiones sobre el existencialismo o de la filosofía existencial que en el caso de José Ferrater Mora, en su visión sobre el existencialismo y la filosofía existencial es mucho más amplia aunque compleja.

Como ya se precisó en el apartado dedicado a la visión sobre el existencialismo en José Ferrater Mora y tomando en cuenta el presente análisis del concepto sobre existencialismo que expone André Comte-Sponville, es importante considerar si los 
elementos existenciales presentes en la filosofía de Ferrater Mora tienen una marcada tendencia en algún contexto o corriente específica. Si es que existe una clasificación del existencialismo, se hace referencia Jacques Maritain, al que José Ferrater Mora evoca en su concepto sobre existencialismo:

"Jacques Maritain ha propuesto otra clasificación: según ella, hay
por un lado un existencialismo propiamente existencial y un
existencialismo meramente académico. El primero es $\ll e l$
existencialismo en acto vivido o ejercido». El segundo es «el
existencialismo en acto significado» como máquina de ideas y
aparato para confeccionar tesis". (Ferrater Mora, 2004: 1176).

Si la tesis de Jacques Maritain se da por el todo acertada, dos grandes bloques estarían clasificados en el universo del pensamiento existencialista. La interrogante que surge es saber la pertinencia que cada corriente existencialista suscite o que según la obra de cada filósofo o sistema filosófico cercano a lo existencial pueda caracterizarse en algún bando delimitado por la tesis de Maritain. Más allá de la obra escrita dejada por algún filósofo o especialista en el existencialismo, cabe preguntar ¿es posible que un filósofo existencialista no esté orientado y formado en una academia, usando los métodos y conocimientos adquiridos y más allá de eso sea un existencialista que ejerce su visión sobre la existencia más allá de lo académico?

El existencialismo que parte desde Sören Kierkegaard, Miguel de Unamuno, Martin Heidegger, Jean-Paul Sartre, Karl Jaspers, entre otros, está impregnado de academia. En el caso de Kierkegaard y de Unamuno, se cuentan como filósofos creyentes, influenciados por lo religioso y sin embargo sus obras están en una categoría erudita, además de poseer sus propios sistemas filosóficos.

Según José Ferrater Mora, "algunos críticos han declarado que Heidegger no ha podido pasar, mиy a pesar suyo, del campo del análisis existencial a la ontología, y que, en general, tal paso no es posible" (Ferrater Mora, 2004:1176). De ceñirse a este criterio, Heidegger pudiera estar clasificado en el existencialismo académico. ¿Dónde estaría Kierkegaard? El sistema filosófico del pensador danés descrito en su obra El concepto de la angustia es sin duda caracterizado por su visión teológica, de filiación a la cultura de la cristiandad, desarrollada bajo el tema del pecado, la angustia que se manifiesta en el pecador, la culpa que lleva por el hecho cometido una transgresión a sus valores doctrinarios y el deseo por la obtención del perdón. 
No puede negarse en el caso de Kierkegaard que hay una condición de "acto vivido o ejercido", consciente de que siendo un cristiano, es un pecador que busca el perdón y eso es causa de su angustia. La angustia de no caer en el descrédito de Dios, de la posibilidad de un castigo como el fuego eterno por no ser perdonado, o la angustia del creyente que duda, bajo la premisa de que la duda o la omisión también es pecado. La angustia de saber si se es perdonado. En este caso lo académico no es lo que resalta en las consideraciones existenciales de Kierkegaard.

Pero en el caso de los existencialistas no creyentes, o aquellos que como Jean-Paul Sartre se declaran ateos y más el filósofo francés que está influido por una formación materialista marxista, pudiese considerarse, si se parte de su obra escrita, que su existencialismo es académico. $\mathrm{O}$ al menos hay un componente significativo de la academia en sus ideas sobre el existencialismo.

¿En qué contexto pudiera estar José Ferrater Mora y sus elementos existenciales? Es importante recordar que el pensador catalán señala su método filosófico como empirismo dialéctico. En José Ferrater Mora destaca sin duda alguna lo académico. Su obra filosófica y enciclopédica hace gala de ello. Pero se debe considerar que José Ferrater Mora no consideró estar incluido en ningún movimiento o corriente existencial (que tampoco negó que sus ideas o sistema filosófico puedan estar impregnado por elementos existenciales) y que se distancia de cualquier etiqueta que lo describa dentro de alguna convención específica en el universo del pensamiento filosófico.

Es posible situar a José Ferrater Mora de acuerdo a las consideraciones que él mismo emitió sobre su "filosofía integracionista". En su obra "Cambio de marcha en la filosofía" (1974), el pensador catalán hizo un ejercicio de filosofía comparada para dar muestra de su método y sistema para filosofar. Desde este plano, puede haber algún tipo de señal que permita establecer si hay o no una filiación categórica de los elementos existenciales considerados dentro del existencialismo académico o existencialismo existencial o si en definitiva el integracionismo o empirismo dialéctico no puede ser catalogado en ninguno de los bloques propuestos por Maritain.

\section{“Filosofia «integracionista»}

Por varios motivos -determinada formación intelectual, intereses variados (en ocasiones, curiosidad), exigencias impuestas por 
trabajos de orden enciclopédico, espíritu tolerante (en el mejor de los casos) o blando (en el peor de ellos)- me sedujeron durante tiempo las posibilidades de combinar o, mejor, integrar ciertas orientaciones, o grupos de orientaciones, filosóficas que parecían contraponerse, o marchar cada cual por su lado; orientaciones que podrían llamarse «humanistas», por un lado, y «científicas»o «cientificistas», por otro. Las primeras se interesaban sobre todo por la vida humana y sus problemas; las segundas atendían primordialmente a la Naturaleza o, mejor, a ciertos conceptos y métodos de las ciencias naturales. Las orientaciones «humanistas» a que aludo no eran necesariamente idealistas, ni tampoco «subjetivistas»". (Sitio electrónico oficial de José Ferrater Mora).

Es pertinente la afirmación de José Ferrater Mora sobre los diversos motivos que lo llevaron a desarrollar e implementar un método que le permite analizar orientaciones o grupos de orientaciones consideradas contrapuestas. Es en ese orden de ideas donde nace el integracionismo. Más adelante, el pensador catalán alude al existir:

"Las más interesantes destacaban que la vida humana es una manera de existir en el mundo, incluyendo el mundo natural, de modo que este último no era simplemente descartado -aunque en la práctica poco, se alcanzaba a decir sobre él salvo la vaga tesis de que era un ingrediente del tándem «sujeto-objeto»-. Además, la vida humana en cuestión no era vista sólo desde el punto de vista del conocimiento; un importante, y decisivo, elemento de ella era la acción, tanto individual como colectiva. Así entendidas, las orientaciones «humanistas» en cuestión no tenían por qué ser la expresión, de lo que William James llamaba «un espíritu delicado», a diferencia del «espíritu fuerte»; filosóficamente, y hasta, o sobre todo, politica y socialmente, muchos adeptos de, orientaciones «humanistas» han sido de una firmeza ejemplar. En cuanto a las orientaciones «cientificistas», no eran necesariamente siempre «objetivistas»o, como, algunos han dicho ( $\sin$ que sepa bien si es una observación profunda o una frase hecha), «fríamente calculadoras»". (Sitio electrónico oficial de José Ferrater Mora).

En cierto modo, la disposición del método integracionista es ubicarse en un ámbito que equilibre las posturas cientificistas, objetivistas, racionalistas, que de acuerdo a sus condiciones materialistas no contemplan "una manera de existir en el mundo". Aquí se nota un rasgo existencial en las comparaciones de José Ferrater Mora al usar el integracionismo para mostrar que no necesariamente lo físico y metafísico sean fenómenos que estén indefectiblemente alejados. A lo que luego agrega el pensador catalán:

"No eran tampoco necesariamente reduccionistas, ni aspiraban a que todo lo que pudiera decirse fuera «científico»; se limitaban a poner de relieve que, cuando de conocimiento se trata, hay que prestar atención a las ciencias, y especialmente a las ciencias naturales, en, donde pueden encontrarse métodos rigurosos y enunciados verificables, o falsables. 
Cada una de estas orientaciones parecía fallar en algunos respectos y acertar en otros. Por más que hablaran, del «mundo», y hasta del mundo natural, las orientaciones «humanistas» tenían poco que decir sobre él, y en particular sobre las cuestiones que su conocimiento científico suscita. Y las orientaciones «cientificistas» no contenían mucho que tuviese gran interés sobre la vida y historia humanas. En vista de lo cual estimé que valía la pena sopesar los respectivos méritos y limitaciones de las orientaciones de referencia, con el fin de integrarlas de algún modo. A ello llamé «integracionismo», vocablo no muy afortunado, pero no mejor ni peor que otros que han sido más favorecidos por la suerte". (Sitio electrónico oficial de José Ferrater Mora).

Nuevamente Ferrater Mora reafirma el carácter del integracionismo al "tender puentes" en las realidades que se contemplan desde el saber científico que no es del todo "reduccionista". Incluso lo que se considera desde el rigor de la ciencia no necesariamente el objeto de lo que se investiga a través de métodos e instrumentos comprobables no llegan a conclusiones determinantes. Por eso las orientaciones consideradas pueden fallar o acertar. Y es desde esta estimación que el escritor hace la respectiva denominación de "integracionismo", ya que busca integrar las referencias que son o pudieran ser de orden contradictorio. Ahora bien. ¿Desde dónde nace el carácter primigenio del integracionismo? José Ferrater Mora afirma:

"Mi primitiva intención era consecuencia del interés citado por muchas y muy diversas tendencias filosóficas, y a la vez contribuía a intensificar tal interés. Observaré que interesarse por, y discutir con, tendencias filosóficas diversas, tanto del presente como del pasado, no es, en principio, ningún mal. El mal estaría en interesarse en ellas porque sí, por mera curiosidad arqueológica o enciclopédica, y también en perderse en un laberinto y contribuir a aumentar la confusión. No veo nada malo en una pluralidad de intereses, y no sólo filosóficos, si ello contribuye a evitar el pensar a marcha-martillo; lo malo sería perder de vista los problemas que se quieren dilucidar. Si en medio de un «inclusivismo» se repara en que sólo cierto «exclusivismo» puede evitar que perdamos el hilo, o que se nos entienda mal, o que no logremos circunscribir con un módico de precisión la cuestión en cada caso tratada, entonces el exclusivismo, como señalaba al principio de este libro, será bienvenido". (Sitio electrónico oficial de José Ferrater Mora).

A pesar de su destacado trabajo recopilador, el sistema filosófico de José Ferrater Mora no es un método (de acuerdo a sus propias consideraciones) de tipo arqueológico y enciclopédico, cabe destacar entonces que su forma de aplicar su análisis tiene también su carácter existencial. Y Ferrater tiene otra consideración de base al respecto:

"Pero no veo por qué debería seguirse siempre el exclusivismo; espero que no sea por un temor al qué dirán (¿qué dirán los amigos?, 
¿y qué dirán los «duros»?). Admito que se vapulee a alguien que nada logra hacer por el mero hecho de interesarse por diversas opiniones, o por debatir con ellas, pero no lo admito porque se interese, o debata. Este es uno de los casos donde la mejor -acaso la única-crítica es ad hominem: dime lo que haces y te diré lo que vale". (Sitio electrónico oficial de José Ferrater Mora).

La importancia de orden filosófico no tiene fundamento sobre algún tipo de debate crítico al que pudiera ser sometido. No es un capricho académico o la búsqueda de un reconocimiento por parte de especialistas o "duros" en la materia. Es filosofar por el gusto de hacerlo. Pero luego se ve y en este sentido alguna vez se dice desde la voz del pensador catalán que su método filosófico tiene influencia kantiana:

"Tampoco es un mal el deseo de tender un puente filosófico entre «las dos culturas», aunque sea sólo bajo forma de un «ideal» (o de una «idea regulativa» en sentido más o menos kantiano), ya que esto nos pone en guardia contra ciertas doctrinas que, a fuerza de ser unilaterales, acaban por ser dogmáticas. Esto no basta, porque hay casos de interés por «las dos culturas» que fallan, pero es o por insuficiente información o por un mal uso de la crítica. Como ha escrito Javier Muguerza, "ahí están los casos... de la teoría de la ciencia de algunos frankfurtianos o la teoría social de algunos popperianos» ambos han hecho lo posible para «tender un puente», pero sólo uno de los tramos -el de la teoría de la ciencia de algunos popperianos o el de la teoría social de algunos frankfurtianos- puede considerarse como respondiendo a las exigencias de una crítica racional, y hasta de una información suficiente. Tender un puente es un buen programa, pero si es sólo programa no se pasará nunca a la otra orilla". (Sitio electrónico oficial de José Ferrater Mora).

A pesar de su influencia, José Ferrater Mora señala que ese "tender un puente" está basado en una forma de un ideal (sin llegar a ser un idealista) estableciendo el "más o menos" de su carácter kantiano, precisamente buscando evitar la unilateralidad de las ideas (a las que también llama "culturas") que las lleva a convertirse en un conjunto de pensamientos dogmáticos. Hasta este punto puede comprenderse que hay una distancia de las ideas de orden existencial en la influencia filosófica, pero de ningún modo hay una negación a lo existencial. Cabe la interrogante de si esta forma de hacer filosofía es acaso una metodología "eclébctica":

"Por otro lado, aceptar simplemente métodos o resultados de una orientación filosófica, o partes de ella, para combinarlos con otros procedentes de orientaciones filosóficas distintas, y generalmente contrapuestas, lleva con frecuencia a un eclecticismo inane. Esta es seguramente la impresión que daba mi propósito de integrar orientaciones contrarias, y esta impresión quedaba confirmada por un empleo de un vocabulario filosófico no siempre idóneo. 
Cuando se traen a colación, aunque sea para discutirlas, doctrinas muy diversas se tienden a usar términos y expresiones que contentan a quienes deberían desilusionar y dejan perplejos a quienes deberían satisfacer. Así, tanto en mi libro El ser y la muerte como en El ser y el sentido empleé términos como 'ontología', 'ontológico', 'real', 'realidad', 'ser', etc., pero una cosa era el sentido que les daba, y otra el que tenían en doctrinas a las cuales me refería, generalmente para oponerme a ellas. Nada de extraño que surgieran malentendidos". (Sitio electrónico oficial de José Ferrater Mora).

Esa forma de hacer filosofía de acuerdo al análisis del mismo Ferrater Mora, da pie a considerar que sí hay carácter ecléctico, aunque ese no sea el fin que persigue el integracionismo. Sin embargo deja acotado que esa consideración pueda ser más bien un malentendido quizás por ciertos hilos discursivos y el uso o aplicación de categorías filosóficas que pueden contribuir a considerar que se trata de un método ecléctico de hacer filosofía, cuando en realidad no lo es. Razón por la cual el pensador catalán coloca el ejemplo de la expresión "el ser" para dar luces al respecto:

"Uno de los mayores procede de los propios títulos. La expresión 'el ser' remitía seguramente a muchos lectores a títulos de libros como 'El ser y el tiempo', de Heidegger, 'El ser y la nada', de Sartre, acaso 'El ser y la esencia', de Gilson -Y hubiera podido remitirles a otros «similares», como 'El ser y el trabajo', de Jules Vuillemin, y no sé si a 'El ser y el decir', de Marcel Reymond (si bien en este último caso se trata de estudios de crítica literaria, con las inevitables gotas de filosofía «estructuralista»). Y confieso que algunos de los mencionados títulos, y en particular los dos primeros, influyeron en la elección de la dudosa expresión el ser', aunque luego resultara que su sentido, era muy distinto del que tiene en cualquiera de los autores citados. En El ser y la muerte, el ser' era una abreviatura para "el continuo de la Naturaleza"; en El ser y el sentido era el nombre de un concepto-límite que expresaba una de las allí dilucidadas «disposiciones ontológicas». En ningún caso la expresión aspiraba a ser designativa. Esto ocurría con todos los términos «ontológicos», incluyendo 'lo que hay', que no era más designativo de lo que es en un autor como Quine, y que era empleado, además, en una acepción muy similar a la de Quine -con el cual podría relacionarse asimismo el uso, de 'ontología' y 'ontológico' (u 'óntico')". (Sitio electrónico oficial de José Ferrater Mora).

Se destaca nuevamente que el uso de "el ser" no obedece necesariamente a una concepción de carácter existencial (o por lo menos relativa en este caso en exclusividad a Jean-Paul Sartre o Martin Heidegger), pero José Ferrater Mora sí reconoce que las obras de los filósofos existencialistas y en el caso de Martin Heidegger se puede hacer la consideración sobre la filosofía existencial, influyeron en la elección nominal de los títulos correspondientes a dos de sus obras destacadas por ser las que exponen en orden primario 
su sistema filosófico. Luego, José Ferrater Mora seguirá describiendo el carácter del método integracionista:

"En vista de ello, y para evitar a cada paso enfadosas aclaraciones, habría sido mejor cortar por lo sano y situarse dentro del contexto filosófico más apropiado al tipo de investigación emprendida. Especialmente en El ser y el sentido tal contexto era analítico, y muchas cosas, habrían resultado más claras de haber planteado los problemas dentro de él.

Más razón había para ello si se tiene en cuenta que el «integracionismo» de referencia no consistía en ninguna combinación de doctrinas, sino en un análisis de conceptos destinado a mostrar primero su contraposición y luego, su posible complementariedad. Se trataba de poner de manifiesto que cada uno de los conceptos de un determinado par funciona como un concepto-límite en la medida en que pueden mostrarse los confines de su aplicación y a la vez su complementariedad con el otro concepto. El «integracionismo» es en este sentido un método de integrar conceptos por medio de un análisis de sus funciones". (Sitio electrónico oficial de José Ferrater Mora).

El intelectual nuevamente insiste en afirmar que su método integracionista es la integración de conceptos por medio de un análisis de orden funcional y que no obedece a una combinación o síntesis de ideas, no es un "sincretismo" filosófico. Es la búsqueda de la "complementariedad" y no la fusión o contraposición de un concepto sobre otro. A este respecto, José Ferrater Mora sigue aclarando:

"En ello se siguen los procedimientos de un análisis filosófico o crítico, lo que es distinto de seguir un punto de vista «oficial» en tales o cuales círculos. Es cierto que aun entonces no es posible despejar todos los malentendidos, los cuales desaparecen solamente cuando se pertenece a un determinado "grupo» o «escuela». Lo último tiene indudables «ventajas ideológicas», incluyendo la de poder decir cosas que no parecen estarles permitidas a los francotiradores. Si se pertenece a un grupo que hace profesión de fe antimetafisica, cabe formular proposiciones metafisicas sin grandes temores de ser mal interpretado por los miembros del propio grupo, y hasta con el beneficio suplementario de ser jaleado por miembros de grupos adversarios. «Si hasta el propio F lo dice, debe de ser cierto.»Y lo mismo, aunque a la inversa, cuando se pertenece a un grupo con propensiones metafísicas; si se adopta alguna actitud anti-metafísica, los «metafísicos» no protestan (o no demasiado) y los «antimetafísicos» se regocijan. Hasta ocurre que uno de los secretos del «éxito» en filosofía reside en empezar por adoptar posiciones bien establecidas dentro de un grupo o escuela, y luego proceder a modificarlos, por radicalmente que sea". (Sitio electrónico oficial de José Ferrater Mora).

Hay otro elemento de caracterización relativo al integracionismo que puede observarse y es en torno a los procedimientos del método, que está compuesto de un 
"análisis filosófico o crítico" y que se distingue de las posturas dogmáticas, de los puntos de vistas "oficiales" respecto a un tema, idea o concepto. Pero el pensador catalán deja en claro que no es posible del todo que las interpretaciones respecto a sus consideraciones sean motivo de especulaciones o posiciones de acuerdo al grupo o escuela a la que pertenezca el analista, crítico, especialista o estudioso de los fenómenos filosóficos en mención. A lo cual José Ferrater Mora añade:

"No se habla entonces de confusiones, sino de «la evolución filosófica del autor». Creo, sin embargo, que no todo debe sacrificarse a evitar malentendidos, y que a menudo hay que resignarse a éstos, con la esperanza de que oportunamente se disuelvan.

Por este motivo, aunque conviene situar una indagación filosófica dentro del contexto que le sea más adecuado, no es necesario prescindir totalmente de referirse a otros contextos, especialmente si ello contribuye a precisar el propio, a la vez que a impedir que prosperen demasiado las tendencias «provincianas». Lo que entonces se hace no es cotejar orientaciones filosóficas para elegir 'lo mejor de ellas', a la manera del ecléctico, sino ver en qué medida una posición filosófica dada tiene supuestos, o desarrolla tendencias, que llevan a plantearse problemas que otras posiciones filosóficas hayan podido tratar". (Sitio electrónico oficial de José Ferrater Mora).

José Ferrater Mora conviene otra vez en señalar que no hay una intención metodológica relacionada a lo ecléctico, que son inevitables los "malentendidos", pero que luego podrán aclararse. Nuevamente Ferrater Mora da una consideración respecto al existencialismo en medio de un marco fenomenológico y el orden de ideas que le anteceden y le preceden:

"Así, se puede discutir si Walter Cerf tiene o no razón al proponer que las investigaciones de Austin constituyen la contrapartida «en modo formal» de la «fenomenología mundana» de Husserl no sólo en virtud de la expresión acuñada por el propio Austin -«fenomenología lingüística»-, sino también porque sus análisis parecen ir por el camino de una dilucidación del «acto, lingüística total» en la «situación lingüística fenomenológica total». Se puede discutir inclusive si, como sugiere Cerf, el paso de la fenomenología mundana al existencialismo, tal como lo bosquejó, malgré lui, Heidegger en las primeras cien páginas de Sein und Zeit, no presagia un paso similar de la fenomenología lingüística a una especie de «antropología filosófica descriptiva» del tipo de la que se rastrea en Stuart Hampshire. O se puede discutir si el paso del construccionismo reduccionista defendido por varios positivistas lógicos al pluralismo de marcos conceptuales elaborado por varios post-wittgensteinianos no representa un cierto paralelo al paso ya clásico de Hume a Kant." (Sitio electrónico oficial de José Ferrater Mora). 
Es preciso en señalar, en el caso de lo que el propio José Ferrater Mora considera una discusión, lo que la "fenomenología lingüística" influye o interviene en los debates y análisis filosóficos. O más bien, como lo señala más adelante, son ejemplos de confrontación filosófica:

\begin{abstract}
"En todo caso, se dan aquí ejemplos de tipos de confrontaciones filosóficas que pueden resultar iluminadoras -siempre que no se abuse de ellas-. No por ello la fenomenología lingüística de Austin deja de ser lingüística. Estas «confrontaciones» resultan apropiadas sólo cuando se establecen entre orientaciones filosóficas «en marcha»; poco, o nada, se sacaría aduciendo similaridades, analogías o contrastes entre un modo de hacer filosofía que se está efectivamente haciendo y otros modos ya hechos y que, sea cual sea el número de sus adeptos, no van ya a ninguna parte. Esto ocurre con todos los "escolasticismos»; con ellos ni siquiera el eclecticismo es admisible". (Sitio electrónico oficial de José Ferrater Mora).
\end{abstract}

Ejemplos que el filósofo destaca como iluminadores porque precisamente permiten "tender puentes", incluso cuando en estas confrontaciones se suman disciplinas no filosóficas como el caso de la fenomenología lingüística, que no necesariamente debe ser el centro de debate en una discusión de orden filosófico, o en palabras del mismo pensador catalán "confrontaciones filosóficas que pueden resultar iluminadoras -siempre que no se abuse de ellas-" no para establecer dogmas o concepciones reduccionistas, que como también señala José Ferrater Mora, los dogmatismos y reduccionismos ocurre lo mismo que con los "escolasticismos" que hacen parecer más admisible el eclecticismo, considerando que confrontar ideas dentro del integracionismo tiene una connotación dialéctica con su debida parte empírica. En este contexto, no es posible establecer si el método integracionista puede estar enmarcado en el existencialismo (aunque estén presentes elementos indefectibles) o en la filosofía propiamente existencial. Sin embargo, se puede hacer un análisis que extiende la lectura realizada en el apartado respectivo a la obra De la materia a la razón, básicamente en tres conceptos, de los cuales dos de ellos más o menos se relacionan al ámbito de la filosofía existencial y también al existencialismo.

El primero de ellos es el concepto de "Criterios" que de alguna forma permite abordar a profundidad el sistema integracionista, con el fin de establecer el acercamiento que pudiera o no tener sobre el existencialismo existencial o el existencialismo académico:

\title{
“Criterios
}


Los fines supersuficientes que propondré no son cosas valiosas o bienes que, por así decirlo, terminan con alcanzarlas. No son, pues, términos en el sentido en que el dar en un blanco es término de la acción de disparar. Aunque sólo se alcanzan cuando se actúa, e interactúa, de ciertas maneras, no son acciones determinadas y aisladas, sino series bien trabadas de acciones e interacciones. Representan, así, modos de vivir y, en la medida en que se juzgan deseables, modelos de existencia”. (Ferrater Mora, 1979: 168).

Hay una clave en el final de la cita anterior: "modelos de existencia". José Ferrater Mora reconoce que modos de vivir corresponden a modelos de existencia, destacando que hay acciones e interacciones, lo que permite dilucidar elementos de carácter ya sea existencialista o existencial. Sin embargo, en el contenido posterior hace alusión a lo racional:

"Cumplir estos fines es estar cumpliéndolos. Para alcanzarlos hay que acudir a ciertos medios, los cuales deben ser racionales, no con una racionalidad parcial, sino con una racionalidad completa, que permita salvar las dificultades que puede suscitar la aplicación de métodos racionales parciales e insuficientes (Mosterín, 1977). Los fines son, a su vez, medios para alcanzar muchos otros fines con la única condición, ya indicada antes, de que ninguno de éstos sea incompatible con aquéllos. En tanto que nos inclinamos en favor de ciertos fines supersuficientes, consideramos que son objeto de un sistema de preferencias, con un concomitante, aunque no forzosamente explicito, sistema de rechazos y repugnancias". (Ferrater Mora, 1979: 168).

El uso del análisis racional o de una racionalidad completa, no indica de modo alguno que el integracionismo sea un método del todo racional. Lo racional obedece a un uso instrumental, incluso como herramienta empleada en un marco metodológico, pero en conclusión no definitorio. Así parte el pensador catalán para definir no el criterio, sino los criterios:

"Empezaré por sentar varios criterios de acuerdo con los cuales adopto el proyectado sistema de preferencias o, si se quiere, de acuerdo con el cual formulo una serie de valoraciones. De los criterios sentados no se derivan necesariamente las preferencias expresadas, ni las que efectivamente se expresan son todas las que podrían expresarse. Cabría, en principio, expresar otras preferencias y, desde luego, expresar otras además de las brindadas. Pero es inevitable que haya una estrecha relación entre criterios para sentar fines y fines sentados, al punto que en algunos casos los criterios mismos pueden valer ya como expresión de preferencias. Sin embargo, para mayor claridad seguiré distinguiendo entre fines (o preferencias, o valoraciones) y criterios. El numerar éstos no quiere decir que se admita sólo una cantidad fija de criterios ni que cada uno de ellos sea perfectamente distinguible de cualquier otro ni que los primeros que se mencionan tengan prioridad sobre los últimos. La numeración y la 
distinción tienen por fin principal la claridad”. (Ferrater Mora, 1979:

168-169).

El método empleado por José Ferrater Mora para hacer referencia a las preferencias que va a emplear no son expresiones que puedan calificar su sistema filosófico. Simplemente las dispone para el fin de exponer y no una plena determinación que las haga distinguibles en la concepción integracionista. El uso de una herramienta o instrumento en primer o segundo orden no dispone una prioridad de uno sobre el otro. Ahora se exponen términos de uso:

"1. He insistido en usar términos como 'fin', 'preferencia', 'valoración' $y$ otros similares en vez de expresiones como «principios morales», «normas morales», etc. Puede alegarse que no hay diferencias básicas entre un sistema de preferencias -presentado, además, como un conjunto de fines- y un código moral, ya que en el sistema se expresa lo que se juzga más valioso, y esto equivale a declararlo inequívocamente "bueno», que es ni más ni menos lo que hace un código moral. Sin embargo, hay ciertas diferencias de «tono» que no me parecen desdeñables.

En esta obra he empleado el vocablo 'moral', pero muy a menudo en expresiones como 'titulado moral', 'juzgado moral', 'considerado moral', 'reputado moral', etc. Varias razones para ello constan en el capítulo sobre la noción de «deberes», especialmente en la sección en la cual he hablado de deberes «morales» como forma, o extensión, de deberes sociales. Pero hay otra razón, que es a su vez manifestación de una preferencia (así como, evidentemente, de una repugnancia). En numerosos casos, lo que muchos seres humanos han considerado moral -o inmoral- ha sido determinado por alguna serie de mandatos en forma de prohibiciones. En este sentido tenía razón Bergson al hablar del «fruto prohibido» como «algo muy antiguo tanto en la memoria de cada uno de nosotros como en la de la humanidad» (Bergson, 1932, pág. l)”. (Ferrater Mora, 1979: 169).

El tema moral es tratado desde los inicios del existencialismo por Kierkegaard en $E l$ concepto de la angustia y aunque José Ferrater Mora cita a Bergson, hay presente un elemento que trasciende lo enteramente académico, ya que refiere a la humanidad. El integracionismo en este caso se ocupa de un tema relativo a la humanidad partiendo de establecer "criterios". Más adelante se observará si es algo meramente casual o determinante. Siguiendo con el tema moral, el pensador integracionista prosigue:

"¿Qué no habríamos hecho de habernos dejado hacer! : «Pero he aquí que un obstáculo surgía, ni visible ni tangible: una prohibición.» No es sorprendente que la palabra 'moral' en muchas de sus formas "esto es (o no es) moral», "éste es un código moral», etcétera, y no digamos «la» moral-pueda causar una impresión que el adjetivo inglés forbidding, con su doble sentido de "prohibitivo» $y$ «repulsivo», expresa vívidamente. 'Preferible', 'valioso' y vocablos semejantes 
tienen, cuando menos por el momento, otro «tono», menos áspero y engolado. Puede seguir hablándose, si se quiere, de criterios morales. Pero entonces éstos tienen el aspecto «funcional» que Xavier Rubert de Ventós (1971, pág. 42) ha encontrado en ellos y que le ha conducido a hablar de "valores» que se siguen de ciertos criterios morales o principios de aprobación. En rigor, sin embargo, no son «valores» que se siguen de «principios», sino más bien «cosas»-actos, disposiciones, situaciones, modos de ser y obrar, modos de interactuar, estilos de vida, etc-valiosas, o juzgadas tales, que sirven de guía y que funcionan como «criterios»o «principios»". (Ferrater Mora, 1979: 169-170).

Los criterios en torno a la moral, sus principios, sus valoraciones se refieren actos, disposiciones, situaciones y modos de "ser". Hay una relación de los criterios con el vivir que está indefectiblemente relacionado al existir, a la existencia y en este caso a lo existencial. En este contexto, el término moral desemboca brevemente en otro autor al que suele mencionarse, a José Ortega y Gasset:

"Reconozco que el carácter poco atractivo del vocablo 'moral' puede atenuarse. Al comentar un texto de Ortega ( [1930] 1947, pág. 72) donde éste declaró que le irritaba dicho vocablo, Aranguren introduce una distinción fundamental entre la moral como estructura y la moral como contenido y manifiesta acto seguido que la segunda se monta sobre la primera. Ello le permite sostener que el hombre es constitutivamente moral (Aranguren, 1958, pág. 73). Pero con esto se abre, espero, el camino para arraigar las disposiciones tituladas «morales» en las estructuras biológicas y sociales del ser humano. La distinción propuesta por Aranguren es tanto más plausible cuanto que, al disertar, algunos años después, sobre el «contenido de la moral», hace emerger éste de la cultura, especialmente de las culturas «abiertas». Es, pues, un «contenido moral que va decantando la experiencia de la vida en el desarrollo histórico» (Aranguren, 1968, pág. 42) y que constituye la fuente de los «códigos morales». Estos pueden resultar entonces menos prohibitivos y repulsivos". (Ferrater Mora, 1979: 170).

En un segundo término, después del análisis inicial sobre la moral en el establecimiento de "criterios", José Ferrater Mora sigue describiendo su sistema de preferencias:

"2. El sistema de preferencias propuesto es fundamentalmente antidogmático. Admite la posibilidad, y aun la necesidad, de crítica y, por supuesto, la posibilidad y la probabilidad de revisión. Admite, y desea el diálogo con otros sistemas posibles, con la condición de que estos se reconozcan asimismo como criticables y revisables. En términos de Jesús Mosterín (1973, pág. 475), el «sistema» de referencia es un programa y no un conjunto de mandamientos. Esto no quiere decir que no haya, por parte del proponente, un compromiso serio con respecto a su programa. Al fin y al cabo, el que propone una teoría científica, que admite y sabe revisable, no por ello la declara 
desde el comienzo falsa, y no por ello carece de interés para buscar hechos y razones que permitan apoyarla. En el caso de un sistema de preferencias por fines supersuficientes, el compromiso es aún mayor, porque, sin descuidarse la aspiración a un conocimiento máximo de los «hechos» pertinentes, se desliza inevitablemente una cierta sensibilidad en las preferencias y en las valoraciones". (Ferrater Mora, 1979: 170).

Antidogmático es parte de los “criterios” que José Ferrater Mora establece tanto para el análisis como para su propuesta metodológica. Es ante todo un diálogo, una posibilidad y una necesidad. Hay un enfoque científico, cierto, pero de ningún modo establece dogmas o como lo expresa Mosterín en la cita anterior mencionada por el pensador catalán un “conjunto de mandamientos". Y ahora se sigue señalando el tema moral:

"No es menester adoptar ninguna de las llamadas "teorías del sentimiento moral» para reconocer el peso que puede tener cierta sensibilidad estimativa o, según los casos, desestimativa. Como sugiere Aranguren (1968, pág. 61), aunque todo contenido moral sea cuestionable -sea en épocas de inseguridad y transición, como apunta el mismo autor, sea, como es probable, en todo momento- queda en pie algo vago, pero perfectamente concreto, que es una «actitud ética». Por ejemplo, un sistema de preferencias que diera cabida a las cámaras de exterminación de Auschwitz, al Gulag o a la tortura, bastaría, a mi entender, para descualificarlo. Creo que hay otras razones para esta descualificación además de una cierta sensibilidad moral. Un «sistema» de esta índole sería muy probablemente uno dogmático y estaría en contra de hechos suficientes conocidos respecto a la naturaleza de todos los seres humanos que no son biológicamente divisibles en razas maestras y en razas esclavas, pero la sensibilidad a la que aludo no es ajena a la formulación de valoraciones, aunque sólo sea porque permite emprender el camino más corto en el momento de proponerlas". (Ferrater Mora, 1979: 170171).

El filósofo integracionista usa un ejemplo histórico para la consideración del dilema moral, incluso establece una valoración respecto al significado de lo que representa el exterminio, la tortura, que son descualificables. Y eso lo atribuye en parte a una sensibilidad moral. Además de antidogmático, Ferrater describe otra preferencia dentro de su sistema integracionista:

"3. Siendo antidogmático, el sistema de preferencias es, a la vez, antiabsolutista. ¿Quiere esto decir que es relativista? Lo es, si por 'relativismo' se entiende la oposición a cualquier absolutismo. Es, desde luego, relativo a una situación, por global y amplia que ésta sea. ¿Quiere esto decir que hay que abandonarse a un escepticismo completo? Se ha visto ya que una teoría científica puede ser aceptada y definida, aun si se sospecha que no va a ser permanente. ¿Por qué asustarse entonces del carácter no permanente de un patrón práctico? Se ha equiparado a menudo el «absolutismo» con el «objetivismo», el 
cual ha sido presentado, además como lo contrario del y la necesaria corrección a todo «subjetivismo». No veo por qué una teoría o un patrón práctico han de dejar de ser objetivos tan pronto como dejan de ser absolutos. Pero si se insiste en que 'absoluto', 'permanente' y 'objetivo' son términos intercambiables, entonces cabe sugerir una posición «intersubjetivista». El intersubjetivismo, expresa simplemente el hecho de que una teoría, lo mismo que un programa práctico que contenga fines supersuficientes, son propuestos a la consideración de todos los sujetos humanos con la aspiración a producir un consenso, incluyendo, una vez más, el consenso de admitir su carácter provisional y su revisabilidad". (Ferrater Mora, 1979: 171).

Su pensamiento lo califica de Antiabsolutista, con su respectivo relativismo siempre que se oponga al absolutismo, pero no es un sistema de preferencias relativistas. El integracionismo tampoco es escéptico. En todo caso es intersubjetivista, con el fin de establecer un consenso. Esto muestra que José Ferrater Mora a pesar de ser un pensador ligado a la ciencia (recordando su Lógica Matemática) no es un cientificista. Otros elementos intervienen en su sistema de preferencias:

"Así, el relativismo y el intersubjetivismo de que hablo testimonian más bien una posición de apertura. Se abren a la posibilidad de considerar otros patrones prácticos y otros sistemas de preferencias futuros, de los que por el momento no tenemos ni siquiera sospecha, porque no sabemos en qué condiciones podrán manifestarse o elaborarse.

Por ser antidogmático y antiabsolutista, el sistema en cuestión no es «deontologista». ¿Será por ello «naturalista»? Si por 'naturalismo' se entiende lo opuesto al deontologismo, así es. Pero 'naturalismo' es un vocablo demasiado amplio para que pueda usarse sin precauciones. No me parece admisible si por él se entiende la afirmación de que hay «hechos morales», objeto de "descripciones» del mismo género que los «hechos»y las «descripciones de hechos» naturales. Me parece, en cambio, admisible si consideramos que los titulados «hechos morales» son, en forma similar a la que había sugerido Nietzsche, interpretaciones de hechos. Al mismo tiempo, estas interpretaciones son hechos humanos y, como tales, hechos que tienen lugar dentro del contexto de sujetos humanos en cuanto individuos biológicos que se desarrollan en un continuo social-cultural (e histórico)". (Ferrater Mora, 1979: 171-172).

El sistema integracionista niega además del dogmatismo y el absolutismo el deontologismo. Esto conduce a pensar en situar al integracionismo en un naturalismo. Pero no es un naturalismo en toda la amplitud del concepto. El pensador catalán es cuidadoso de situarse dentro de las etiquetas o patrones que suponen juicios que hagan una delimitación de su sistema filosófico. Por eso, él seguirá expresando lo que interpretara por naturalismo: 
"Como puse de relieve en otro lugar de esta obra, no entiendo por 'naturalismo' una doctrina según la cual hay una naturaleza humana completamente invariable y, en principio, enteramente cognoscible, ya que si tal ocurriera, tendríamos, según también apunté, un patrón absoluto, no muy distinto del postulado por el deontologismo. La llamada «naturaleza humana»es, a la vez, una naturaleza «social»e «histórica», y cualquier «naturalismo» comporta a la vez un cierto «culturalismo»y un cierto «historicismo»". (Ferrater Mora, 1979: 172).

Apegarse a un término determinante, sobre todo si este término ejemplifica muchos sistemas de pensamiento que hasta pueden tener profundas contradicciones, es lo que procura a toda costa evitar José Ferrater Mora. Los "ismos" para él representan una condena y no un espacio de libertad. Por eso reporta el uso de los ismos en su carácter instrumental más no esencial. Ahora prosigue estableciendo las pautas de sus preferencias:

\begin{abstract}
"4. Lo dicho en varias páginas anteriores permite colegir que hay un número muy grande (en principio, infinito o, cuando menos, indefinido) de fines suficientes. En tanto que estos fines se valoran positivamente, son objeto de preferencias, o pueden serlo dadas las circunstancias apropiadas. Sin embargo, no incluyo tales fines en el «sistema» porque éste concierne sólo a cosas valiosas de índole muy básica o, como he dicho reiteradamente, «supersuficiente», es decir, a fines que, dada la situación de la cual. Partimos, se estiman valiosos en todas las circunstancias hasta el momento previsibles. En vez del «maximalismo» de las valoraciones relativas a fines suficientes, adopto, para los fines supersuficientes, un «minimalismo». Me parece que conviene, en efecto, reducir a un mínimo su número. De este modo cabe admitir como posibles y legítimos muchos actos y muchos modos y estilos de vivir que una gran mayoría de códigos morales insisten en declarar reprobables. Al ser tan pocas las valoraciones introducidas en el sistema de preferencias, y al ser, además, tan generales, se corre (y acepta) el peligro de incurrir en la vaguedad". (Ferrater Mora, 1979: 172).
\end{abstract}

En sus preferencias hay un inequívoco carácter minimalista. Ese minimalismo expresado en sus preferencias evita los peligros de la superficialidad y la vaguedad. Y eso lo precisa en lo analizado por los códigos morales es sus debidas estimaciones y valoraciones. A esto se agrega las situaciones concretas y las relaciones concretas:

"Sin embargo, cabe reducir ésta considerando que la precisión se obtiene no mediante la aplicación de «fines» $o$ «principios» a casos y a situaciones particulares, sino más bien ejecutando una operación inversa: considerando qué casos y situaciones particulares pueden permitir oportunamente precisar y especificar qué sentidos cabe dar a las valoraciones que se formulen. De este modo pueden ponerse de relieve las dificultades que van apareciendo, y cuando éstas resultan insuperables puede procederse a introducir revisiones, mayores o menores. No podré, en esta obra, tratar debidamente este aspecto 
importante de la cuestión que sólo puede afrontarse al examinar con algún detalle «situaciones concretas» $y$ «relaciones concretas». Me limitaré a indicar que la parquedad de las valoraciones presentadas tiene asimismo otra razón: los fines supersuficientes oportunamente mencionados son lo bastante arduos de alcanzar para que nos abstengamos por el momento de aumentar su número". (Ferrater Mora, 1979: 172-173).

El asunto de las "situaciones concretas" y las "relaciones concretas", que en su aplicación hay "fines" y "principios", puede también observarse el carácter dialéctico del sistema integracionista. Una dialéctica no hegeliana, pero tampoco distante a Hegel. Una dialéctica que según se lee en la siguiente cita está impregnada de la experiencia cotidiana:

"5. El mejor conocimiento posible de la situación en que nos encontramos requiere el conocimiento de los hechos integrantes de esta situación. A este conocimiento contribuyen muy diversas fuentes: el saber científico -tanto de las ciencias naturales como de las sociales-, la experiencia y el conocimiento históricos -que es experiencia y conocimiento de «ensayos y errores»-, lo que llamamos «experiencia cotidiana»-que es la experiencia personal y la que deriva de lo que sabemos de la experiencia de otras personas-, etc. Si llamamos a todo esto, para abreviar, «razón teórica», diremos que lo que, también para abreviar, llamamos «razón práctica», está montada sobre o, como mínimo, es concordante con la razón teórica. La primera no se deriva lógicamente de la segunda, pero se encuentra simplemente en el aire si no apela a ésta”. (Ferrater Mora, 1979: 173).

Se puede ver una descripción en resumen del sistema de preferencias ferrateriano, los diversos elementos que componen el integracionismo, como lo son el saber científico, que incluye ciencias sociales y naturales, la experiencia y el conocimiento histórico y la experiencia personal. También tiene un "mínimo" de razón teórica y razón práctica. Todo este conjunto sin duda alguna permite ver que hay una presencia de la filosofía existencial cuando se menciona la experiencia cotidiana o la experiencia personal. Al no considerarse José Ferrater Mora un cientificista (a pesar de tener un evidente saber científico), se permite valorar que lo humano, lo biológico y lo metafísico tiene un peso significativo en su propuesta filosófica. En síntesis ¿Qué propone todo esto? El filósofo integracionista responde:

"Así, en vez de retrotraernos a una supuesta «situación originaria», partimos de una situación «postoriginaria»; en vez de tender un «velo de ignorancia» (Rawls, 1971, § 24, págs. 136-42), presuponemos una masa de conocimientos y experiencias. La situación "postoriginaria» de la que hablo es la que resulta de la serie de situaciones en las que se han encontrado los seres humanos en el seno de sus diversas sociedades, a través de la historia y en el curso de su evolución biológica". (Ferrater Mora, 1979: 173-174). 
En este párrafo, José Ferrater Mora dispone en torno al desarrollo de sus ideas la necesidad de trascender la "situación originaria" para no presuponer y quedar atado a una situación estática. Presuponer es en cierto punto quedarse plantado en lo histórico de una situación y lo ideal en este caso es seguir el curso de la evolución biológica a lo que esto se denomina una situación "postoriginaria". Eso conduce a una integralidad del conocimiento, ampliar el saber más allá de lo que origina una situación vista desde su sistema de pensamiento, como lo sigue expresando:

\begin{abstract}
"Por supuesto que nadie puede pretender poseer tan vasto conocimiento. Pero cualquier sistema de preferencias que se establezca y cualquier conjunto de fines que se juzguen deseables no están desligados de lo que podría llamarse «una idea del mundo». Esto explica por qué he dedicado una parte sustancial de la presente obra a las que he llamado «realidades». El sistema (mínimo) de preferencias que sentaré está encuadrado en esta concepción de las «realidades» y forma, además, parte de éstas. Es posible que preferencias análogas puedan ser propuestas partiendo dé una concepción de las «realidades» y de una «idea del mundo» distintas de las ofrecidas. Pero me parece que puede encontrarse un encaje máximo entre mi primer examen -el de las «realidades»- y mis últimas sugerencias las «valoraciones»-, sobre todo si se tienen en cuenta los puentes tendidos concernientes a las «acciones» y a los «deberes»". (Ferrater Mora, 1979: 173-174).
\end{abstract}

Sistema de preferencias para un fin específico no indica una idea de totalidad o absolutismo metodológico para hacer filosofía y sobre todo para abordar realidades. Eso puede conllevar que se expongas ideas que puedan ser inconexas, distintas desde su factor originario y por esto el integracionismo no es necesariamente un sistema de pensamiento que establezca "una idea del mundo". El integracionismo puede afirmarse como una forma de filosofía existencial para analizar las situaciones y realidades sin que eso conforme una visión de mundo que esté ligada a algún tipo de reduccionismo. José Ferrater Mora sigue dando pautas sobre los criterios de su filosofía:

"6. El último criterio que mencionaré puede resumirse con el vocablo «anti-antropocentrismo». De varios de los puntos desarrollados en esta obra puede colegirse la idea de que la importancia que se ha concedido a menudo al ser humano en el régimen general del universo, ha sido exagerada, deformada por un ideal antropocéntrico según el cual el mundo ha sido hecho para el hombre o, lo que viene a ser lo mismo para nuestros efectos, según el cual el mundo ha evolucionado física y biológicamente -y luego, social, cultural $e$ históricamente- de tal modo que el hombre ha terminado por «imponerse» a la Naturaleza, dominándola y apropiándosela. Rechazo este ideal por estimar que haya mediado una creación o, como lo conjeturo, un desarrollo físico y biológico, ello no justifica 
que el hombre deje de ser una parte de la Naturaleza o, si se quiere, que su realidad sea continua, y se halle coordinada con el resto de la Naturaleza. El que en ciertos respectos el ser humano esté mucho más desarrollado que otras especies, inclusive algunas biológicamente muy próximas a él, no le otorga derechos para imponer sus apetencias de dominación sin límites.” (Ferrater Mora, 1979: 174).

A pesar de que José Ferrater Mora considera no ser afecto a posiciones extremas, considera que su sistema filosófico es "antiantropocéntrico", ya que rechaza la idea de que lo existencial gira únicamente en torno al ser humano y que el ser humano debe ejercer dominio y poder sobre todo lo existente. Es digna la mención del amor que el filósofo expresaba por los animales. Él estaba en contra de esas consideraciones que justifican el que hombre es superior a todas las especies biológicas conocidas. Respecto a lo humano y cultural sigue disertando:

"Por el contrario: las estructuras culturales que ha ido creando en el curso de la historia y el desarrollo de sus potencias racionales le imponen «obligaciones». La cláusula «Para nosotros, los seres humanos...», que hasta ahora ha sido repetidamente usada, consciente $o$ inconscientemente, puede reformularse del siguiente modo: «Para nosotros, los seres humanos, en tanto que coexistimos, y convivimos con el resto de la Naturaleza...» El cumplimiento de la «obligación» aludida no es incompatible necesariamente con el desarrollo máximo de las estructuras culturales -las cuales incluyen la invención y uso de recursos tecnológicos. No es necesario, ni conveniente, que el hombre vuelva a la Naturaleza en el sentido de hacerse menos civilizado o más «primitivo», y, sobre todo, de hacerse menos «racional». Una vez más, los posibles males de la cultura y de la racionalidad pueden curarse con una cultura y una racionalidad aún más completas". (Ferrater Mora, 1979: 174).

Lo que en sí mismo constituye el declarado "antiantropocentrismo" de José Ferrater Mora, equivale precisamente a tener una postura en exceso racionalista, incluso el exacerbado culto al desarrollo tecnológico, lo que en palabras del autor son los posibles males de la cultura y la racionalidad, entendiendo que a través de la aplicación de un pensamiento basando en la integralidad de las relaciones, situaciones y criterios de amplitud puedan sugerir una cura a estos males, males que la misma cultura y racionalidad pueden ser usados para curar aquello que le causa flagelo, referente al malestar en la cultura.

Considerando los "Criterios" que permiten caracterizar al integracionismo, José Ferrater Mora luego pasa a otras categorías que pudieran más o menos ubicarse en lo existencial, como a continuación se apreciará: 


\section{"Vivir}

La primera preferencia en el «sistema mínimo» propuesto es tan básica que parece demasiado simple: vivir es preferible a no vivir. El que sea simple no es, sin embargo, argumento para rechazarla. Tiene razón John Kenneth Gailbraith (1977, pág. 16) al escribir que "cuando las cosas son simples, hay que evitar complicarlas, ya que hay otras maneras de exhibir la sutileza». ¿Habrá que reconocer que, en todo caso, la idea es trivial? En rigor, no lo es tanto, ya que podría argüirse contra ella. Por ejemplo, Schopenhauer mantuvo que hay una «Voluntad de vivir» que anida en todas las realidades y que constituye inclusive «la realidad misma». Esta Voluntad se impone irresistiblemente al punto que no se puede hacer nada contra ella. En consecuencia, los seres humanos creen que se trata de una cosa valiosa, y, por tanto, de un objeto de inequívoca preferencia. Pero si Schopenhauer tiene razón, se trata (de un impulso ciego e irracional que no produce más que dolor. Mejor es, pues, eliminarlo. Un modo radical y efectivo sería suprimir la vida misma o, en todo caso, autoaniquilarse. Los animales no lo hacen así, porque no están dotados de razón." (Ferrater Mora, 1979: 174-175).

Es precisa la referencia de José Ferrater Mora al tema de la voluntad relacionado con Arthur Schopenhauer cuando establece que la voluntad es un impulso ciego e irracional que produce dolor. Es allí donde hay un símil con categorías relativas a la filosofía existencialista e incluso las de carácter existencial. Dolor y angustia (es pertinente recordar la obra del filósofo danés Sören Kierkegaard sobre la angustia) y es aquí donde el pensador catalán refiere a la no dotación de la razón en los animales. Aunque los animales tienen la capacidad de sentir dolor y de seguro de estar en alguna situación extrema pueden padecer angustia. Siguiendo esta analogía sobre el humano y el animal, el filósofo integracionista sigue disertando:

\footnotetext{
"Pero si el ser humano es un animal, es, dice Schopenhauer, un «animal metafísico», que debería darse cuenta de la última inanidad de todo esfuerzo con el fin de conservar la vida o, en todo caso, conservar, propagándola incesantemente, la especie. Si la autoaniquilación parece, por paradoja, poco civilizada, siempre queda la posibilidad de sumergirse en el arte o de entregarse a la compasión. Para Schopenhauer, por tanto, y para todo pesimista convencido, no es cierto que vivir sea, sin más, preferible a no vivir. La preferencia por la vida es la preferencia por una ilusión”. (Ferrater Mora, 1979: 175).
}

Nuevamente otro tópico existencial, aparece la compasión que tiene indefectible relación a esas realidades hondas del ser que se expresan por haber experimentado dolor y angustia. Cuestiones que pueden generar un espíritu de autoaniquilación que también se relaciona a un estado de conciencia pesimista, indicando que no tiene sentido el vivir, aunque también esa voluntad que tiene dualidad haga que el hombre, como está expresado 
en la Biblia, desee la eternidad en su corazón. Entonces hay una voluntad de vivir, como puede haber una voluntad de no querer vivir. A todo esto José Ferrater Mora agrega:

"Si se prefiere vivir a no vivir es, pues, porque se supone que vivir es una realidad positiva, que merece impulsarse y respetarse.

El vivir de que aquí se habla es primariamente el vivir humano, pero no se reduce a él; el respeto a la vida humana se da dentro del horizonte del respeto a, y del impulso de, toda vida. En efecto, la vida humana resulta empobrecida si no va acompañada de otras vidas y, a la postre, del conjunto de la naturaleza orgánica, articulada en ecosistemas. La inteligencia y la conciencia son formas de vida, que tienen sus soportes naturales y que se han desarrollado a partir de éstos. Puede abusarse de la inteligencia y de la conciencia para destruirlos, pero con ello se destruye la vida misma de la cual emergen". (Ferrater Mora, 1979: 175).

Importante lo que José Ferrater Mora considera respecto a la conciencia humana y es que la vida no depende únicamente de que un ser humano tenga la certeza de que vive, sino que para sentirse vivo debe estar rodeado de otras vidas (humanas y no humanas) pero también en un plano metafísico, considera que la inteligencia y la conciencia son formas de vida, ya que hacen vida dentro de un organismo, es lo inorgánico en lo orgánico. ¿A qué más se refiere el pensador catalán respecto al vivir? Él responde:

El vivir de referencia no es pura y simplemente un subsistir, como si de lo único de que se tratara fuera seguir existiendo. Los seres orgánicos se caracterizan por un impulso de «sobrevivencia», cuando menos en lo que afecta a la propia especie. Se caracterizan asimismo por un constante despliegue de una energía que, a falta de mejor vocablo, llamaremos, redundantemente, y más o menos nietzscheanamente, "energía vital». Sin la energía vital y su dispendio, la vida no es muy vividera. Ello explica, dicho sea de paso, por qué aun en ausencia de grandes fines a realizar, y aun en presencia de numerosas aflicciones, depresiones y desalientos, hay en la mayor parte de los casos una indudable preferencia por el vivir, o el seguir viviendo. Se ha dicho a veces que la vida (cuando menos, la vida humana) es absurda, y que no tiene sentido. Pero ello sólo quiere decir que no hay nada «más allá de la vida», ningún sentido que no radique en la vida misma. Afirmar que vivir es preferible a no vivir es decir que el vivir se basta, y que no es menester buscar algo en virtud de lo cual se vive". (Ferrater Mora, 1979: 175-176).

Además de que el ser humano está consciente del vivir, está el sobrevivir, cuestión que también caracteriza a otras especies o seres orgánicos. Es un impulso que también puede considerarse estar inmerso en el tema de la "voluntad". Tema que también puede referirse a Nietzsche (tributario de Schopenhauer en lo que respecta a la voluntad) por su concepto de “energía vital”. ¿Qué implica además el vivir? José Ferrater Mora dice: 
"Una vez sentado lo anterior, es preciso reconocer que para que el vivir sea preferible a no vivir es necesario que haya en la vida cualidades que la hagan merecedora de ser aceptada. Pienso en rasgos como los siguientes: un cierto goce, o impulso, de vivir, aun en los momentos de mayor desaliento; ciertas expectativas o posibilidades de realizar proyectos, desde los más exaltados hasta los más humildes; el respeto a sí mismo; la ausencia del temor de que la vida individual tiene, como así ocurre, un término inevitable. Puesto que la muerte es el fin de la vida, y ésta es preferible a su ausencia, la muerte no es, propiamente hablando, objeto de preferencia. Sin embargo, en tanto en que la muerte individual forma parte del programa de la vida orgánica, es aceptable como un ingrediente de esta vida". (Ferrater Mora, 1979: 176).

Nuevamente, el pensador catalán suscribe las cualidades que hacen del vivir un impulso deseable: el goce o placer y los posibles proyectos que puede desarrollar a lo largo de su existencia en el plano orgánico y material. Pero luego hace referencia a otro tema con rasgo existencial: la muerte. La muerte como elemento inevitable en el proceso de la vida orgánica, incluso la muerte que le da sentido a la vida. ¿Qué otro elemento de carácter existencial está implicado en el vivir? José Ferrater Mora describe:

"Las limitaciones de la preferencia por el vivir sobre el no vivir no son ignoradas en virtud de lo que acabo de enunciar. Supongamos que, con el fin de seguir viviendo, hay que sufrir, por lo pronto, físicamente. Estimo que no sufrir es preferible a sufrir. Pero hay muchas maneras, grados e intensidades de sufrimiento. ¿Qué ocurre cuando el sufrimiento es intolerable? Casi todas las doctrinas morales, salvo la estoica, predican o que hay que aguantar el sufrimiento supuestamente intolerable, o que hay inclusive que darle la bienvenida, porque de este modo nos hacemos dignos de una mayor y ulterior recompensa. A ello se debe que muchas doctrinas morales rechacen el suicidio o la eutanasia. Me parece que en este respecto los estoicos tenían razón. Por supuesto que no recomendaban ni el suicidio ni la eutanasia salvo como remedios extremos; en puridad, mantenían que debemos fortalecernos tanto como podamos con el sufrimiento con el fin de no tener que sucumbir al menor infortunio. Algo similar podría decirse cuando, por alguna razón, más o menos justificada, una persona se siente envuelta en la ignominia. La cualidad de la vida puede entonces descender a tan bajo nivel que el vivir no sea ya objeto de preferencia". (Ferrater Mora, 1979: 176).

Sufrimiento. Sufrir como proceso, como lo es el goce, el placer, sufrir en el dolor, sufrir en la angustia y sufrir ante la posible llegada de la muerte. Se presenta el dilema de vivir preferible a no vivir. No sufrir preferible a sufrir. No angustiarse preferible a angustiarse. Gozar preferible a no hacerlo. Hay en esta consideración de orden existencial un componente dialéctico. A este respecto, el pensador integracionista expone: 
"Así, puede cualificarse la preferencia: "Es mejor vivir que no vivir» de varios modos sin desecharla. La vida tiene un valor superior a la no vida en condiciones especificadas, aunque nunca completamente y absolutamente especificables. No obstante, ninguna de estas condiciones hace que la ausencia de vida como tal sea preferible a su presencia. Si sacrifico mi vida por otra persona, si la sacrifico por una causa que estimo justa, no por ello tengo que concluir que «no vivir» es, sin más, preferible a vivir. Si pudiera salvar a la otra persona, o si pudiera defender la causa que estimo justa, sin sacrificar mi propia vida, ello sería mejor aún; al fin y a la postre, terminada mi vida, puedo hacer muy poco, o nada, por nada. Cuando se ha dicho que morir de pie es preferible a vivir de rodillas, se ha dicho, en rigor, que vivir de rodillas no es vivir; que el vivir de rodillas no tiene la cualidad que hace el vivir preferible al no vivir". (Ferrater Mora, 1979: 177).

La preferencia respecto al vivir tiene implicaciones éticas, morales y de juicios de valor. Vivir, de acuerdo a las circunstancias en las que se pone a riesgo o se viven situaciones extremas, es una decisión. Defender una causa, defender otra vida, defender la vida puede implicar que se dé la vida misma de la cual se tiene por preferencia el vivirla. A este respecto José Ferrater Mora continúa disertando:

"A la preferencia por el vivir sobre el no vivir, agrego la siguiente: es mejor convivir que aniquilarse. Como la primera, esta segunda preferencia tiene un aspecto demasiado simple. Parece, además, lo mismo que la primera, o equivocada o, en el mejor de los casos, trivial”. (Ferrater Mora, 1979: 177).

Vivir además implica tomar la decisión de no querer aniquilarse. Vivir implica convivir, que puede ser considerado soportar, tolerar, o sentir lástima, compasión o conveniencia. Hay otro ingrediente que el pensador integracionista señala en lo que respecta a la existencia:

"Para empezar, tanto en el mundo orgánico como en el mundo social y cultural, un ingrediente básico de la existencia parece ser la lucha lo que se llamó antaño, más o menos patéticamente, «la lucha por la vida»-. Un ser orgánico no parece poder subsistir sin una cierta dosis de agresividad, la cual comporta a menudo la eliminación de obstáculos, incluyendo a otros seres vivientes. Se ha hablado por ello de un proceso en el curso del cual unos seres vivientes -miembros en una especie, o especies dentro de otras especies- caen y otros siguen en pie, siendo los últimos los que Spencer, en su extravagante mescolanza de progresismo, reaccionarismo y «darwinismo social» llamó «los más aptos». El proceso parece reiterarse, con las modificaciones pertinentes, en el mundo social e histórico, donde ni la convivencia, ni la tolerancia mutua ni la paz han sido normas que hayan regido invariablemente la constitución y el desarrollo de las sociedades humanas o de grupos e individuos dentro de estas sociedades". (Ferrater Mora, 1979: 177). 
El factor de lucha, un factor que puede tener una serie de implicaciones, que tanto la ciencia evolucionista como la tradición filosófica positivista y también ciertas consideraciones de orden racionalista y progresista llaman a los que sobreviven en la lucha "los más aptos". La lucha implica agresividad (y por lo tanto violencia), que pudiera ser determinante cuando un individuo o ser puedan establecer un sistema de preferencias donde decida que es preferible no vivir al vivir. Al igual que el vivir implica momentos de goce, de placer, de paz, es indefectible que haya sufrimiento, dolor, angustia, violencia, agresividad, intolerancia y aniquilación. Nuevamente, los factores de carácter existencial vuelven a toparse con una situación de orden dialéctico. Por eso el pensador integracionista añade:

\begin{abstract}
"Que, en el mundo orgánico, la agresión y la lucha son hechos, es innegable. Que sean los únicos hechos dignos de tenerse en cuenta, es dudoso. Entre los miembros de diversas especies animales tienen lugar luchas del tipo de las llamadas «luchas rituales», las cuales representan una forma, por primaria que sea, de «convivencia». Ha podido observarse una especie de «cooperación ecológica» en el hecho de que una especie animal no destruye por completo a otra especie animal. Convivencia y cooperación no son, pues, forzosamente «innaturales», como no lo son tampoco ciertos impulsos de ayuda mutua. El comportamiento de seres naturales no da pie, por tanto, a rechazar la, convivencia. ¿Será ésta más bien la víctima del desarrollo social y cultural humano? En cierta medida, así es: al aumentar en proporción gigantesca su poder sobre la Naturaleza, los seres humanos han aumentado asimismo en gigantesca proporción el poder de unos sobre otros, desencadenándose de este modo ese tejido de matanzas y crueldades que ocupa una buena porción de la historiografía y que es tanto más deplorable cuanto que es en muchos casos perfectamente gratuito. El poder es, desde luego, un hecho y a la vez una necesidad, como lo es, y no menos, la rebeldía contra el mismo. Parece, pues, completamente utópico hablar de convivencia." (Ferrater Mora, 1979: 177-178).
\end{abstract}

El pensador integracionista reconoce que la lucha, la agresividad y la violencia componen un hecho en la existencia. En la vida orgánica, las especies antagonizan, unas viven de la energía de las otras, pero ello no necesariamente implica aniquilación. La convivencia es un factor clave para supervivencia, incluso es un factor de equilibrio. Los leones no pueden aniquilar a todos los antílopes o cualquier mamífero al que esa especie tenga como posible alimento. El león toma la vida de la cebra porque necesita que su especie sobreviva, pero esa violencia que ejerce no implica el querer matar a una manada completa de cebras. A diferencia de lo señalado, el hombre comete actos de maldad y crueldad que no se comparan en lo absoluto con la violencia en el reino animal. Pero es 
preciso acotar que los humanos pueden ejercer bondad, altruismo, consideración por alguien en alguna situación en desventaja, compasión, solidaridad, que hacen posible la convivencia incluso pacífica. Pero debe reconocerse que sigue el problema del dominio de unos sobre otros, causando en el sistema de preferencias de muchos humanos condiciones pesimistas, de angustia, dolor y la no preferencia de vivir. Hay además otras consideraciones que el pensador catalán expone:

"Sin embargo, no es así, especialmente si no entendemos por ella una especie de blando y vago acuerdo. Hasta cabría afirmar lo opuesto: el acuerdo es muchas veces resultado de una especie de conformismo y, con ello, consecuencia de alguna violencia ejercida por la sociedad entera, o por los miembros de ella que han logrado imponer su voluntad al resto.

La convivencia de que hablo es simplemente la tolerancia, dentro de la cual puede haber, e inclusive debe haber, todos los desacuerdos, disputas y luchas que se quieran. 'Tolerancia' es, por descontado, una palabra pasada de moda, usada para acribillar las supuestas ingenuas esperanzas de los «ilustrados». Pero de la «ingenuidad» de los «ilustrados» hay todavía mucho que hablar. Es posible que algunos, o hasta muchos de ellos, promovieran el ideal de tolerancia sólo para la protección de sus particulares intereses. Pero esto no disminuye un ápice las virtudes de la tolerancia; indica únicamente que se trataba de una tolerancia parcial”. (Ferrater Mora, 1979: 178).

A pesar de que la convivencia es en este caso equivalente a la tolerancia, José Ferrater Mora señala que los humanos suelen convenir de acuerdo a sus intereses la parcialidad o la no totalidad de la aplicación de la tolerancia, entendiendo que si se ejerce la violencia en su contra puede conllevar a su respectiva aniquilación. Está implicado un tema de voluntad, la voluntad que puede imponer una sociedad sobre otra, sean o no minorías, o élites de poder. Por eso José Ferrater Mora infiere que la tolerancia para el mejor desarrollo de la convivencia no debe ser aplicada en términos medios, como se aprecia a continuación:

"Una radicalización de la tolerancia puede, en cambio, ayudar a curar sus propios vicios. Varios autores han manifestado que no se puede -o, mejor, no se debe- tolerar el error, de modo que la tolerancia tiene sus límites. Para con el «error», hay que ser intolerante. Esto es, sin embargo, sólo uno de los disfraces que la intolerancia adopta. Supone que se sabe, o se puede saber (y a menudo que alguien sabe), con completa certidumbre lo que es «el error»y, por tanto, lo que es «la verdad»: lo que es injusto y lo que es justo, lo que es inaceptable y lo que es aceptable, lo que es punible y lo que es recompensable. «La verdad» cubre aquí una gran variedad de asuntos: a veces son ideas religiosas o ideologías politicas; a veces, ciertas clases sociales o ciertas razas. Por lo demás, el hablar de «la 
verdad» y del «error», como hacían los tradicionalistas del pasado siglo contra los detestados «ilustrados», indica ya bien por dónde van los tiros: van todos ellos hacia blancos sospechosos". (Ferrater Mora, 1979: 178-179).

Un rechazo de la cultura, ese malestar que implica el conflicto con el otro, conflictos que nacen por considerar al otro inferior por motivos de raza, clase social, ideas religiosas, orientaciones políticas o de carácter ideológico, hacen parecer que la intolerancia es una condición natural, que la tolerancia tiene sus límites, que en todo caso puede ser enfrentada la intolerancia con la radicalización del bienestar, el bienestar que confiere la aplicación de la tolerancia, el no querer imponerse sobre el otro, conscientes del poder de la voluntad. El integracionismo no deja por fuera de la vida estas características que relacionan a lo orgánico con lo inorgánico. Elementos de carácter existencial que suponen una dialéctica entre el ser, la vida y la muerte y en todo esto, el vivir.

Ahora bien, vivir se expresa en elegir, en tomas decisiones, en ejercer su propia voluntad. ¿Cómo aborda el integracionismo este tópico? José Ferrater Mora lo sugiere de esta forma:

\section{"Ser libre}

La segunda preferencia en el "sistema mínimo» de fines dignos de perseguir, o de seguir manteniendo, reza como sigue: "Ser libre es preferible a ser esclavo.»

Esta es una preferencia que prácticamente todo el mundo estaría dispuesto a mantener-especialmente si se formula del modo indicado, con el término 'esclavo', que arrastra toda clase de connotaciones ingratas. Sin embargo, el acuerdo dura sólo hasta el momento en que se solicitan detalles.

Antes de entrar en ellos, quiero poner de relieve que la preferencia por la libertad frente a la esclavitud (y, como se verá luego, contra toda especie de sumisión o servidumbre) es resultado de un proceso histórico". (Ferrater Mora, 1979: 179).

Lo existencial es inherente a la forma en cómo se vive, en cómo se expresan las acciones de la convivencia y sobre todo en las relaciones de poder. Ser libre tiene esa significación existencial que contiene todo un espectro complejo y que el pensador catalán dispone en desarrollar:

"La esclavitud pudo haber sido un «mal menor» en épocas en las que, en el curso de una guerra, los prisioneros tenían sólo dos alternativas: ser matados o convertirse en esclavos. En este caso, la esclavitud era preferible a la muerte; al fin y al cabo, el esclavo puede pensar que le será posible escapar, o que, andando el tiempo, será manumitido. Pero una vez la esclavitud establecida, se presenta ya la alternativa 
entre ésta y la libertad, y la última tiene la preferencia sobre aquélla. La tiene en todos los casos, inclusive cuando suponemos que el esclavo llega a la conclusión de que quiere seguir siendo esclavo. Esta es una conclusión a la que se puede llegar sólo dentro de una sociedad esclavista, pero resulta que en este tipo de sociedad el esclavo no puede decidir libremente; lo que decide es su conciencia de esclavo y no de ser libre. Ampliando la noción de esclavitud a la de sumisión, cabría decir lo propio de ésta: en una sociedad sometida, la decisión de ser sometido no es una decisión libre". (Ferrater Mora, 1979: 179).

En el sistema de preferencias, José Ferrater Mora analiza el factor de la esclavitud como elemento histórico donde la convivencia y la sobrevivencia están contenidas. Esclavitud en contraposición a la libertad. Pero la esclavitud puede estar contrapuesta a la muerte. Preferible ser esclavo que estar muerto, o como se expresa en el Eclesiastés, "mejor perro vivo que león muerto". Pero ser esclavo no es una decisión de voluntad propia. Es una impostura, ya que la decisión de permanecer vivo, pero como esclavo es una medida extrema para el que está sometido. Hay detalles por considerar:

"Los detalles que se solicitan cuando irrumpe el desacuerdo respecto a la preferencia por la libertad suelen ser importantes. Algunos estiman, con buenas razones, que de poco o nada le sirve el ser libre a alguien que no tenga donde caerse muerto, y que en esta situación es una farsa asegurarle que goza de libertad. No solamente no puede hacer prácticamente nada para expresar esta libertad, sino que inclusive ha de sacrificarla en aras a la mera supervivencia física. Otros consideran, sensatamente, que la oportunidad que se les ofrece en ciertas sociedades a sus ciudadanos de parecerse todos unos a otros, es una mofa de la libertad. Esta supuesta libertad no es sino una manifestación de conformismo, a menudo acompañado de irritantes desigualdades. Resulta, pues, que desde el momento en que expresamos una preferencia por ser libres, topamos con la dificultad de que no sabemos muy bien lo que esto pueda querer decir.

Como es improbable que pueda jamás dilucidarse este asunto cabalmente, tomaré el sendero más corto, y sugeriré tres ingredientes constitutivos de la libertad". (Ferrater Mora, 1979: 179-180).

El tema de la libertad tiene su relatividad. Ser libres en una sociedad puede también ser considerado estar envuelto en una serie de convenciones que más bien indican una adaptación o aceptación que pueden estar condicionados por factores que relativizan la libertad. Por eso José Ferrater Mora sugiere ampliar el concepto de libertad categorizándola en tres ingredientes:

Uno es que la libertad es tanto «negativa» como «positiva», es decir, es tanto una libertad «de» como una libertad «para». En tanto que libertad «de», gozar de libertad es estar liberado del temor, de la opresión, del hambre, de la injusticia, etc. En tanto que libertad 
«para», la libertad es libertad para llevar a cabo proyectos, ninguno de los cuales debe oponerse a la «libertad de».

El otro es el carácter indivisible de la libertad. Como la sociedad es como un modelo del que pueden dar una representación una serie de vasos comunicantes, la supresión de la libertad en un sector, que puede parecer al principio insignificante o ventajosa sólo para algunos, lleva, tarde o temprano, a la supresión de todas las demás libertades. En este sentido, consideremos un aspecto de libertad bien claro: el de la libertad de expresión, esto es, el de la libertad que debe tener todo miembro de una comunidad para manifestar sin temores sus opiniones sobre los modos cómo funciona la comunidad, sobre los modos como a su entender debería funcionar, sobre las reformas que habría que introducir para que funcionara como leal y sinceramente entiende que debería ser, etc. Se han alegado varios argumentos contra este tipo de libertad”. (Ferrater Mora, 1979: 180).

La libertad expresada desde el ejercicio de las facultades humanas, libertad de temor o del miedo, libertad de acción y libertad de pensamiento, que se traduce en libertad de expresión. Pero es entendido que todos estos aspectos son relativos. Si se ejerce la libertad de expresión es porque hay una situación que puede estar oprimiéndola. $\mathrm{O}$ hay el peligro de que la libertad sea oprimida. La libertad de expresión que se ejerce no implica que haya plena libertad de acciones. Ser libre es un ejercicio de la voluntad sobre las imposturas:

"Uno, aludido antes, el de que es una libertad espúrea en una comunidad que puede acaso otorgar libertad de expresión a cada ciudadano, pero que hace inefectiva esta libertad. Otro, también señalado, el de que se trata de la libertad sólo de algunos, a menudo los llamados «intelectuales», y que lo que importan son cosas más sustanciales, como el mantener una vida decorosa, el protegerse contra la violencia, contra la enfermedad, etc". (Ferrater Mora, 1979: 180).

Un dilema que expresa José Ferrater Mora es quién o quiénes pueden hacer ejercicio de su libertad de expresión. ¿Privilegio de intelectuales? Hay preferencias que pueden estar sujetas a cuestiones que otros consideran más pertinente, de vida o muerte o la evasión de la violencia. El pensador catalán ahora advierte:

"No niego que estos argumentos pueden ser importantes, pero sigo creyendo que en cualquier caso la libertad de expresión es fundamental. Para empezar, esta libertad no es incompatible con las cosas sustanciales antes apuntadas. Pero, en todo caso, si empieza por negarse tal libertad, las demás peligran. Supongamos un régimen que con el fin de proteger a los miembros de la comunidad contra el hambre o la desigualdad económica, reprime la libertad de expresión. Las consecuencias se hacen sentir pronto: o el régimen en cuestión se convierte en un «elitismo» de nuevo cuño, con pretensiones liberadoras que ocultan la protección de intereses particulares, o bien se corta toda posibilidad de ulteriores cambios, que la libertad de 
expresión puede, con todas las dificultades que se quieran, ayudar a introducir”. (Ferrater Mora, 1979: 180-181).

Si bien es cierto que la libertad de expresión es un factor clave en las preferencias, sobrevivir quizás imponga las otras libertades, sobre todo aquellas relativas a factores de índole material, como el acceso a alimentos y el poder satisfacer necesidades fisiológicas. Entonces puede darse el caso de la represión de la libertad de expresión porque hay intereses de poder que imponen su voluntad en deterioro del ejercicio de la libertad plena. Es pertinente considerar el tercer ingrediente en la caracterización de las libertades que expone el pensador integracionista:

"El tercero de los ingredientes constitutivos de la libertad es el que la libertad es siempre libertad de posibilidades. Estas son de muchas clases: económicas, políticas, artísticas, religiosas, intelectuales, etc. Este tercer ingrediente se halla estrechamente unido a los demás; en rigor, los tres ingredientes citados están imbricados.

Desde estos puntos de vista, podemos plantearnos el problema de cómo «medir» el grado de libertad en una dimensión dada: consiste en escrutar hasta qué punto está cerrado o abierto el horizonte para posibles cambios. Lo que se opone a la libertad es, en efecto, no sólo la servidumbre o la conformidad, sino también el estancamiento". (Ferrater Mora, 1979: 181).

La libertad de posibilidades es una libertad integral. Una libertad que explora cambios o al menos permite soñarlos, planificarlos, una libertad con un entorno ideal, una libertad de movimiento y acción. Sin embargo no puede decirse que esta libertad está por encima de las dos enunciadas anteriormente. ¿Se puede determinar si una libertad está por encima de las otras? José Ferrater Mora responde:

"Cabe alegar que si nos empeñamos en proporcionar algo así como una «lista de libertades», advertiremos pronto que algunas parecen ser más importantes que otras. Advertiremos asimismo que ciertas libertades requieren condiciones sin las cuales son ilusorias; que para alcanzar ciertos fines se necesitan regulaciones que son otras tantas limitaciones de la libertad, etc. Aunque todo ello es cierto, sólo muestra que los términos 'libertad' y 'libre' son usados o en un sentido demasiado laxo o en un sentido demasiado estricto. Para cruzar una calle con mucho tráfico es menester regular la circulación y con ello prohibir el paso de vez en cuando, sea a vehículos, sea a peatones. ¿En qué medida representa esto una limitación de la «libertad», en este caso «libertad de cruzar la calle» o de «circular por la calle» en todo momento? Para instituir un sistema de seguridad social es menester asignar números a personas, especificar fechas determinadas que establecen cuando empieza a regir el sistema para cada personal considerar que, por ejemplo, una persona tiene derecho a los beneficios de la seguridad social en el año en que 
cumpla los sesenta y cinco, sea el primero de enero o el 31 de diciembre, etc". (Ferrater Mora, 1979,:181).

El pensador integracionista enfatiza que algunas libertades parecen más importantes que otras, pero añade que todas están condicionadas, por lo tanto se vuelve al espacio de la relatividad. La libertad de acuerdo a ciertas convenciones, está limitada. Hablar de límites pareciera o sugiere que aparentemente no hay libertad total, ser libres no es condición plena. En todo caso la plenitud puede alcanzarse si no se observa el ejercicio de la misma en el más irrestricto de los sentidos. Hay leyes que regulan el ejercicio de las libertades, a lo que José Ferrater Mora hace un interrogante que él mismo responde:

\begin{abstract}
¿En qué medida la burocratización del sistema, o el hecho de que el propio sistema sea de índole burocrática, coarta la libertad de cada uno? Mi opinión al respecto es la siguiente:
\end{abstract}

En primer lugar, se coarta la libertad cuando una regulación da por consecuencia la invasión de la existencia privada de cada individuo, esto es, la parte de la existencia del individuo cuya actividad, sea cual fuera, no perjudica la existencia y la actividad de otros individuos. Las ventajas o inconvenientes que puede deparar tal libertad recaen entonces sobre el individuo mismo. No es legítimo despojarle de ventajas, si las hay, y no es legítimo coartar su libertad en nombre de posibles inconvenientes si es conocedor de éstos y los acepta. Desde luego, si las acciones de un individuo perjudican a otro de un modo efectivo e irremediable, hay razones para limitar su supuesta libertad, ya que la libertad no es entendida como libertad de perjudicar, a menos que el perjuicio sea asimismo aceptado. Estimo que soy libre de fumar cincuenta cigarrillos de marihuana al día, pero no de llenar de humo de marihuana una habitación en la cual haya otros individuos que consideren el humo pernicioso. (Ferrater Mora, 1979: 181-182).

Es clave la afirmación del filósofo al expresar que la libertad es una libertad libre de inconvenientes, pero siempre que esa libertad no se ejerza en perjuicio de otro u otros individuos. Entonces la libertad pasa a limitarse, regularse para que el ejercicio de esa libertad no coarte la libertad del otro. Eso incluye libertades de orden biológico y fisiológico:

"Soy libre de procrear, pero si el estudio de mis condiciones fisiológicas da por resultado la presunción, demostrable al máximo, de que nacerán hijos mongoloides, hay razones para que no se me permita semejante actividad. Es obvio que, dado el fuerte componente social en los seres humanos, hay numerosos casos en los que hay que tener en cuenta dónde, cómo y hasta qué punto la libertad de uno afecta o no la existencia, el bienestar, y hasta la propia libertad de otro. Sin embargo, en los casos en los que hay dudas, la eliminación de coacciones es la mejor apuesta". (Ferrater Mora, 1979: 182). 
Ser libres implica ser responsables. Ser conscientes, cuando decir libertad no significa libertinaje o ser libres es inherente a que los demás también sean libres, libres de elegir, de tener posibilidades y de poder expresarse. Y todo eso implica regulaciones:

"En segundo lugar, aun en los casos en los que se consideren
necesarias regulaciones que, al parecer, limitan la libertad, ésta es
efectivamente limitada sólo cuando se supone que las regulaciones
adoptadas son la única solución posible y definitiva a un problema, en
vez de ser, como lo son todas las soluciones, condicional y provisional.
La libertad de cruzar la calle cuando a uno le venga en gana es una
libertad poco importante. Lo importante, sin embargo, en éste y en
otros casos más serios, es que se permita ofrecer la posibilidad de
otras soluciones. Es posible que en las condiciones de las urbes
modernas, la única solución razonable para cuestiones que afectan al
tránsito rodado y, al de los peatones sean los semáforos. Pero no veo
por qué no se puede disputar la solución siempre que se presente otra
que parezca más adecuada que la vigente”. (Ferrater Mora, 1979:
182).

Aunque José Ferrater Mora muestra el ejercicio de la libertad en el marco de una sociedad que regula las acciones en beneficio de una sociedad, se toma en cuenta la importancia de la libertad de todos los sujetos y no la de un sujeto. La libertad es social, es colectiva, pero a la vez se plantea que el individuo se sienta protegido en el marco de esas regulaciones o de las soluciones que son de bien común, lo que permite que haya una sociedad abierta como lo señala a continuación:

"El grado de libertad de una sociedad es, en último término, el grado de apertura de esta sociedad con respecto a sus propias posibilidades. Lo mismo ocurre con la libertad del individuo. Libertad es, pues, siempre libertad respecto a un futuro, no realizado pero que se espera realizable. En la libertad hay una dosis, inevitablemente muy crecida, de indeterminación. Por eso a medida que la libertad se va determinando y precisando, se le van cerrando sus caminos. Para que el futuro sea libre es menester que ni la sociedad ni el individuo se cierren, ni siquiera en nombre de específicas libertades. Puesto que me he metido en la ruta de algunas furiosas generalizaciones, terminaré produciendo una que es abstrusa, críptica y, sin embargo, sobradamente razonable: la libertad es libertad para la libertad". (Ferrater Mora, 1979: 182-183).

La libertad es sin duda inherente a lo existencial. La libertad es una construcción y se construye con acciones, con la interacción social y el factor humano. La libertad del individuo debe significar la libertad del otro y la libertad de los otros. Ser libres para que los demás sean libres. 
15. Concepción existencial del hombre.

15.1. Lo inorgánico, lo orgánico y lo humano.

Según su contraportada De la materia a la razón se trata de un libro "que expresa adecuadamente el viaje conceptual que emprende". De acuerdo al prefacio que hace el autor, José Ferrater Mora tenía varios nombres, muy distintos al título que se está considerando. Dichos nombres guardan cierta relación con otras elaboraciones del pensador catalán que contienen la esencia de su sistema filosófico.

El primer nombre en ser considerado por el autor barcelonés fue: Ser, hacer y deber ser:

"Por desgracia, el término 'ser' es poco de fiar. En El ser y la muerte $y$ El ser y el sentido, 'ser' (con el artículo determinado) es usado como un comodín. En el primer caso es empleado como una abreviatura de 'todo lo que hay' y a veces como una abreviatura de 'la Naturaleza' - de todo lo cual se afirma que cesa o, en un vocabulario más «humano», que «es mortal»-. En el segundo caso es usado para designar un rasgo ontológico de cualquier cosa que haya -lo que es tal y cual, o tiene tales o cuales rasgos o propiedades-. Introducir de nuevo la expresión 'El ser', aunque fuera simplemente a modo de título, hubiera aumentado aún más la confusión”" (Ferrater Mora, 1979: 13).

Partiendo de las consideraciones del ser, se pretende analizar de forma sucinta a través de una lectura de los diversos contenidos en De la materia a la razón, la maduración del sistema filosófico integracionista y que constituye de manera excepcional: el ejercicio de su metodología en forma práctica, que a su vez revela el uso de lo que José Ferrater Mora también denominó "empirismo dialéctico", obrando de acuerdo a sus postulados en diversos ámbitos, en lo profundo y cotidiano, aunque sin descuidar aspectos "triviales" que conforman estructuras en las particularidades del ser.

¿Hablar de lo orgánico e inorgánico puede definirse en algún modo desde el integracionismo? Ante tal interrogante será el propio José Ferrater Mora quien afirmará:

"En la concepción que ha llegado a ser por antonomasia clásica se ha distinguido entre dos «mundos»: el mundo natural y el mundo moral. Se supone que el primero está constituido por hechos y que éstos se hayan regidos por leyes naturales, sean causales o estadísticas. Se supone que el segundo está constituido por acciones e intenciones, que son en principio libres y que deben conformarse con ciertas máximas, imperativos, prescripciones o normas" (Ferrater Mora, 1979: 122). 
Aunque José Ferrater Mora establezca cierta distinción entre dos mundos, el natural y el moral, no hace ninguna sentencia para reducir a exclusivamente dos conceptos no relacionados en forma determinante, no necesariamente existe así una separación absoluta, pero en todo caso puede caracterizarse, tal y como seguirá acotando:

"No todas las acciones conformables según normas, e inclusive constituidas por normas, son necesariamente morales. Las acciones que se ejecutan al jugar al golf, y las normas de acuerdo con las cuales se llevan a cabo las jugadas -o inclusive de acuerdo con las cuales determinadas acciones son consideradas como jugadas- no tienen por qué ser morales, o inmorales" (Ferrater Mora, 1979: 122).

Se percibe en su análisis respectivo a actividades como las profesionales o las deportivas en este caso, a pesar de ser reglas o convenciones, no se obedece en rango absoluto al tema moral, sino que son meras disposiciones para reglamentar una forma de ejecutar un juego o dinámica determinada. A este respecto sigue observando:

"Las preferencias que se emiten cuando se habla una lengua, y las reglas de acuerdo con las cuales se habla -o inclusive de acuerdo con la cuales determinadas expresiones son consideradas como preferencias de la lengua- no tienen tampoco por qué ser morales o inmorales. En cambio puede considerarse como inmoral una jugada en la cual se engaña al contrario haciéndole creer que se cumple, sin que efectivamente se cumplan, las reglas del juego; y puede considerarse como inmoral una preferencia en la cual se promete algo a alguien sin la menor intención de cumplir la promesa (sic)" (Ferrater Mora, 1979: 122-123).

Como se puede apreciar, José Ferrater Mora establece que en un determinado juego las reglas no conforman una actividad moral en sí misma, pero si se actúa de forma indiferente respecto a la ejecución de una regla determinada, se pasa al plano moral, hallándose una violación a la norma del juego establecida de antemano, ya que es una actividad reglamentada y es de suponer que al jugarse se somete moralmente al cumplimiento de la norma. Introduce a este respecto el engaño como consideración de la violación de la norma, ya que la norma en sí no constituye una consideración, pero en cambio la artimaña o violación a la norma o a las reglas establecidas sí lo son.

Así se tiene que existe la libertad de obedecer o no la norma, de ejecutar de acuerdo al "libre albedrío" el cumplimiento de una regla que puede valorarse desde la moral o quizás desde algún principio ético. Por esta razón, José Ferrater Mora relaciona al ser con la acción o intención, el ser orgánico que actúa de acuerdo a criterios establecidos, normas, 
regulaciones, leyes y convenciones que bien pueden o no obedecerse o ser transgredidas de acuerdo a una forma de actuar. Siguiendo con el carácter moral, José Ferrater Mora apunta:

"En la concepción que nos ocupa, se tiene en cuenta exclusivamente acciones o intenciones $-y$ a veces inclusive solamente intenciones-, así como normas, prescripciones, máximas e imperativos de carácter juzgado moral. Concomitantemente, la libertad de que se habla es una libertad moral, y hasta se estima que solo esta última es propiamente parte del mundo moral. En la medida que los actos humanos son considerados como hechos naturales, no son libres, trascienden las leyes naturales" (Ferrater Mora, 1979: 123).

Para Ferrater Mora, hablar de libertad es hablar del mundo moral, mundo que se considera inmaterial o inorgánico, a pesar de que la moral es parte del ser que ejecuta acciones desde sí, pero con la particularidad de que hay una decisión que no corresponde necesariamente a una ley natural que lo conduzca a una acción que pueda o no controlar.

Desde el integracionismo, José Ferrater Mora dispone de una especie de "comodín" para las respectivas caracterizaciones que realiza desde los aspectos correspondidos a concepciones, en este caso del mundo natural en comparación al mundo moral. En relación a este señalamiento, el pensador catalán prosigue:

"Así, el mundo natural es equiparado a menudo con el mundo de la libertad, pudiendo afirmarse alternativamente o que hay libertad por exigirlo el mundo moral o que hay mundo moral en la medida en que haya libertad" (Ferrater Mora, 1979: 123).

El integracionismo aplicado a esta dialéctica del mundo moral y mundo natural, puede distinguirse en las siguientes apreciaciones:

“'Moral' es un vocablo de muy dilatado sentido y cualificable muy diversamente. Por ejemplo, si llamamos «morales» a un conjunto de prescripciones, el sentido de 'morales' será muy distinto según se sea más o menos rigorista o más o menos carismático, según si se cumple lo que se considera como un deber por el propio deber o por razones distintas del deber, según se insista más o menos en la idea de autenticidad o se manifieste una mayor o menor hostilidad a ella, según se esté dispuesto a subordinar la religión a la moral, o ésta a aquélla, etcétera" (Ferrater Mora, 1979: 123).

Precisamente, el término moral, que muy bien puede estar definido de acuerdo a consideraciones de orden teológico o religioso, no siempre precisa una caracterización rígida o determinante. Hay diversidad interpretativa y quizás facultativa, que va de acuerdo al uso o acción, donde la moral no equivale a religión o viceversa, pero sí puede en todo caso haber una conexión que pudiera considerarse o no indefectible según sea el caso. 
El integracionismo, como empirismo dialéctico, o como sistema que busca integrar tipos de pensamiento o sistema antagónicos, persigue una resolución o acercamiento sin que haya una delimitación que haga que un sistema sea absorbido por otro. Siguiendo con el tema moral, José Ferrater Mora añade:

"Las diferencias entre diversas clases de doctrinas morales no son desdeñables, porque unas se prestan más que otras a tender o no un puente entre el mundo natural y el mundo moral y, en general, entre el título «ser»y el llamado «deber» («deber ser»o «deber hacer»)" (Ferrater Mora, 1979: 123).

En este caso no busca reducir, delimitar, desdeñar, descartar, enlazar de algún modo las cualidades en las consideraciones respectivas. Pero todo esto no quiere decir, que no se presenten situaciones, que de acuerdo a las comparaciones de rigor en ideas consideradas disimiles, no existan separaciones de algún modo irreconciliables:

"Sin embargo, en la medida en que se siguen manteniendo dicotomías del tipo «causal-libre»o «natural-moral», se concluye que el «reino moral», en cuanto reino del «deber» es independiente del, e inclusive incomparable con él, reino del «ser»" (Ferrater Mora, 1979: 123).

Hasta ahora, en la lectura realizada se puede distinguir que José Ferrater Mora ha mantenido una relación discursiva en torno a lo moral como parte de un mundo distinto al natural, sin referir en ningún momento sus respectivas correlaciones, sobre todo porque él seguirá más adelante haciendo consideraciones que van de lo moral a lo natural como sigue en lo expuesto por el escritor:

"Es común reconocer que para alcanzar ciertos fines deben
ejecutarse ciertos actos. Si se quiere que un gas en un recipiente
cerrado aumente su temperatura habrá que hacer algo para que las
moléculas del gas se muevan más rápidamente. En rigor, el moverse
las moléculas del gas más rápidamente y el aumentar su temperatura
son lo mismo, de modo que puede decirse similarmente que si se
quiere que las moléculas de un gas se muevan más rápidamente hay
que calentar el recipiente que las contiene y con ello aumentar su
temperatura" (Ferrater Mora, 1979: 123-124).

Este ejemplo se diferencia al exponerse un tema sobre la física, que forma parte del mundo natural, de lo orgánico. Se realiza una determinada actividad que luego conlleva a un determinado fin, incluso este fin se verá ejecutado de acuerdo al tipo de respuesta que se dé de acuerdo a la acción que se considere pertinente. A partir de este momento se verá involucrado un factor distinto al ser, que interviene desde la acción:

“'Hay que', 'se tiene que', 'es menester', 'se debe', etc., expresan aquí el modo con que se dan las instrucciones necesarias para 
alcanzar el fin deseado. No hay ninguna razón para que el fin perseguido «deba» ser perseguido. Pero ¿no ocurre lo mismo en muchos otros casos? Si Ricardo no se enamora de Catalina, ésta se sentirá defraudada. Por tanto, si se quiere que ésta no se sienta defraudada habrá que recomendar a Ricardo que se enamore de Catalina. Sin embargo no hay ninguna razón por la cual Ricardo deba enamorarse de Catalina. Si lo hace, es solo para no defraudarla. Bertoldo tiene que demostrar un teorema matemático si quieres ser admitido en la Academia de Ciencias Exactas. Pero no hay razón por la que Bertoldo deba ingresar en tal Academia. Antonio debe frenar su automóvil si no quiere estrellarse contra un muro; etc." (Ferrater Mora, 1979: 124).

Desde estos ejemplos parte el 'deber' como fórmula intrínseca del ser. No siendo la razón lo único que opera en el deber, también operan situaciones y consideraciones que conllevan a acciones. Acciones que en algunos casos puedan ser de carácter activo o pasivo, que dependerá de la circunstancia. El debe como 'deber', deber por necesidad o no, puede que el deber sea impulsado por una cuestión moral o un impulso emocional. O por la necesidad extrema como en el último caso, para salvaguardar la vida. José Ferrater Mora prosigue considerando:

“HHay algunos fines de tal naturaleza que «deban» ser perseguidos? Si los hay, entonces 'debe' no indica solamente lo que hay que hacer con el fin de alcanzar un fin; indican que el fin mismo debe ser perseguido. Supongamos que salvar la propia vida, sea uno de tales fines, y que Antonio está a punto de estrellarse contra un muro cuando conduce un automóvil. Habrá aquí dos «deberes» de tipo distinto. Según uno, Antonio debe frenar su automóvil si no quiere estrellarse contra un muro, poniendo con ello su vida en peligro, pero si quiere realmente estrellarse contra el muro y poner con ello su vida en peligro es mejor que no use los frenos. Según el otro, Antonio debe salvar su propia vida. Este es un deber-frecuentemente llamado «deber moral»o, simplemente, «el deber»-, y Antonio deberá cumplirlo. Para cumplir con él, deberá entonces, en la circunstancia indicada frenar su automóvil. Paradójicamente Antonio será libre de no cumplir con el deber de salvar su propia vida, pero sólo si es libre podrá perseguirlo, no se dice entonces que deben ejecutarse tales o cuales actos para alcanzar tal o cual fin, sino que decimos que deben ejecutarse tales o cuales actos, sin más" (Ferrater Mora, 1979: 124).

Conforme a la lectura realizada, el deber no es una sola cosa. El 'deber' y 'el debe' tienen distintos ángulos, tópicos y consideraciones que están caracterizados de acuerdo a las circunstancias, que además pueden desencadenar diversas acciones. Las decisiones desde el 'deber' y 'el debe' van a ser puntuales de acuerdo a factores de necesidad, de obligación o del simple deber (moral o no) relativo a la voluntad del ser. Desde esa consideración José Ferrater Mora dispone a continuación de los sentidos del deber: 
“Tenemos entonces dos sentidos de 'deber': uno es el «deber para»o el «deber con el fin de»y otro pura y simplemente «el deber». Este último sentido de 'deber' ha llevado a muchos autores a separar el deber, en cuanto «deber moral», no solo de todo «ser», sino también de todas otras formas, meramente condicionales, de «deber». El «deber moral» de referencia ha sido considerado a veces como "necesario», pero se ha entendido 'necesario' como 'obligatorio'. Esta necesidad no es, en efecto, una necesidad «física» en virtud de la cual sucede lo que tiene que suceder de acuerdo con alguna ley natural" (Ferrater Mora, 1979: 124-125).

Posterior a la concepción del deber desde los dos sentidos arriba anunciados, José Ferrater Mora complementa, ejemplificando mediante las reflexiones del francés Henri Bergson:

"Bergson (1932, págs. 19-20), adujo el ejemplo de una sociedad de hormigas, cuyas actividades se suponen determinadas enteramente por los otrora llamados «instintos» y los que ahora consideraríamos estructuras genéticas (más condiciones ambientales). En una sociedad de este tipo, afirmó dicho autor, podría haber una hormiga que, antes de ejecutar una acción biológicamente determinada, tuviese durante una fracción de segundo una lumbre de inteligencia. Entonces esta hormiga se diría a sí misma con respecto a su acción: "Es necesario porque es necesario», lo cual podría ser igualmente la formulación de un imperativo categórico de tipo kantiano. Pero aunque es cierto que para un ser completamente racional el imperativo adopta la forma de una necesidad, se supone que esta necesidad no es natural, sino moral. Puede discutirse si de hecho hay alguna diferencia entre estas dos necesidades, y si un ser racional moral es libre si está obligado a actuar moralmente. Si se afirma que hay alguna diferencia, es solo porque se mantiene que «ser libre»y «obrar moralmente» son una y la misma cosa, y que ésta es completamente opuesta a «no ser libre»y $a$ «estar determinado causalmente»" (Ferrater Mora, 1979: 124-125).

Debe acotarse que en los sentidos del deber interviene el uso de la inteligencia y no lo meramente instintivo. Entendiendo que ser humano forma parte de un grupo de seres biológicos y muchas de sus acciones están determinadas por las estructuras orgánicas y por el entorno, hay decisiones que se apoyan en la voluntad y por ende en la inteligencia. Aunque no por esto la decisión es indefectiblemente basada en alguna razón o argumentación sólida. Se puede considerar en este caso una razón empírica o una razón dialéctica o la simple decisión de acuerdo a un estado de ánimo. Pero también la razón puede obedecer a una necesidad que concede obligatoriedad. La voluntad en este caso se ve sometida a la causalidad o al devenir que la sujeta. Los sentidos del deber hablando de cómo obrar en determinado momento por determinados factores, aunque sujetos a necesidad, son decisiones relacionadas al "ser libre" y al "obrar moralmente", pudiendo ser 
el caso de un deber sujeto a una acción obligatoria por situación extrema o no. El filósofo sigue ahondando al respecto:

"Si se estima que se debe hacer algo simplemente porque se debe (moralmente) hacer, entonces obviamente hay que las dos antedichas clases de «deberes». Cuando se contrapone el «ser» con el «deber», se entiende este último en las segundas de las acepciones mencionadas. En este sentido, el deber es primariamente, si no exclusivamente, un deber moral. No se afirma entonces que se debe hacer tal o cual cosa para alcanzar un determinado fin-si se quiere, además alcanzar tal fin-, sino que se afirma que debe hacerse porque es moralmente obligatorio hacerla" (Ferrater Mora, 1979: 125).

En las estimaciones consideradas por José Ferrater Mora, los sentidos del deber, están contrapuestos al ser. El deber se enmarca dentro de lo moral, incluso desde una obligación ética, es allí donde se pudiera mencionar el "sentido del deber", sobre todo para alcanzar ciertos o determinados fines. El ser puede o no considerar involucrarse en una acción determinada y por voluntad propia negarse o reafirmarse, pero no es indefectiblemente enmarcado en el mundo moral, mas desde las clases de deberes, hay un deber manifiestamente moral, que es el que permite alcanzar un fin.

Por lo pronto, el intelectual seguirá haciendo gala de sus análisis bajo la metódica integracionista, ya que desde el lenguaje, prosigue con sus consideraciones, ahora con el tópico de la costumbre:

"El término latino mos se traduce habitualmente por «costumbre». Podríamos, según ello, considerar como moral todo lo que afecta a costumbres o en general a modos de comportarse. La moral ha sido considerada a veces como una «doctrina de las costumbres», de modo que sabemos algo de moral cuando sabemos algo sobre costumbre. Sin embargo, el modelo de separación entre el «deber» (moral) y otros «deberes», presta escasa o nula atención a la mencionada etimología. Una costumbre es un hábito adquirido en el curso del trato social. Ciertas costumbres son socialmente aceptables, y otras socialmente inaceptables, pero en cada caso las razones que se dan son sociales y no morales. Se verá oportunamente que muchas costumbres que han sido consideradas morales han mostrado ser sociales, al punto que la historia de las llamadas «sociedades», y específicamente las tituladas «sociedades civilizadas» se ha caracterizado por la proliferación de normas relativas a costumbres sociales convertidas en morales" (Ferrater Mora, 1979: 125).

Entre el ser y el deber se inserta no solamente lo moral, sino también lo social. Y en la inserción de lo social es considerada la costumbre -"hábito adquirido en el curso del trato social"-, ante lo que en el acto aconseja: 
"Ello sugiere ser más cautos de lo que es habitual en la calificación de un «deber» (o de una norma) como moral, y hasta sugiere negar que haya deberes o normas específicamente morales. Por el momento, sin embargo, estoy tratando de comprender por qué se ha establecido una separación entre las dos indicadas clases de «deberes» y por qué, o cómo, una de estas clases de deberes es considerada como última. Una de las principales razones de adoptar este punto de vista es el admitir que una costumbre puede ser socialmente aceptable y ser en cambio, moralmente repudiable; y también, concomitantemente, que una costumbre puede ser socialmente inaceptable, y también (aunque mucho más raramente) moralmente loable. Al adoptarse semejante punto de vista, la dimensión social queda, en principio, separada de la moral. Lo que se hace no es necesariamente lo que se debe hacer, y lo que se debe hacer no es necesariamente lo que se hace. Se hace lo que se hace, y se debe hacer lo que se debe hacer. No se niega que pueda haber «incentivos» para hacer lo que se debe hacer, pero lo que se debe hacer debe hacerse, aun en el caso de que no haya tales «incentivos»" (Ferrater Mora, 1979: 125-126).

A pesar de ello, José Ferrater Mora aclara a qué está haciendo referencia, así como en qué niveles o zonas serán focalizadas sus apreciaciones, advirtiendo además la oposición a las ideas de Immanuel Kant presentes en sus teorizaciones:

\begin{abstract}
"Aunque no me refiero a ellas explícitamente, y menos aún en detalle, es obvio que algunas de las opiniones aludidas han sido expresadas con gran fuerza, y con gran acopio de poderosos argumentos por Kant (K. p. V., passim; Grundlegung, passim). Será oportunamente obvio que en los puntos aquí dilucidados, las opiniones que se expresarán serán casi siempre opuestas a las de Kant. Ello no significa: 1) Desconocer el interés permanente de las tesis kantianas de las fuerzas de sus argumentos en defensa de las mismas; 2) Suponer que la ética kantiana es siempre, y sin más, trivial, vacua, unilateral o imposiblemente rigorista. Es justo reconocer que Kant se anticipó a muchas de las objeciones que se han formulado luego contra sus doctrina morales. Se ha dicho inclusive que muchas, si no todas, las objeciones de referencia son, a la postre, interpretaciones defectuosas de su tesis (por ejemplo, Lewis White Beck, 1959, págs. XVI-XX). Si se parte de ciertos supuestos, resulta imposible, o cuando menos sumamente difícil, "refutar» a Kant. Lo que ocurre es que en este libro se parte de supuestos distintos de los kantianos, y ello lleva a consecuencias asimismo distintas" (Ferrater Mora, 1979: 126).
\end{abstract}

Evitando malas interpretaciones, con la clara intención de transmitir con la mayor claridad, admitiendo los tan distintos, como válidos o legítimos modos de hacer filosofía. Basado en este razonamiento prosigue su consideración:

"Se ha planteado a veces el problema de si merece considerarse que es posible o no hacer lo que se dice que se debe hacer. Unos pocos autores han parecido dispuestos a afirmar que deben hacerse ciertas cosas aun si es imposible hacerlas, e inclusive que deben hacerse justa y precisamente porque es imposible hacerlas. No es menester, 
sin embargo, ir tan lejos en ese camino. El propio Kant -que en manera alguna descuidó el papel que desempeñan los deseos, las inclinaciones y los intereses- estimó que si debe hacerse algo, tiene que poder hacerse. Pero sea cualquiera la opinión sustentada al respecto, sigue manteniéndose la diferencia no sólo entre el «deber»y el «ser», sino también entre varias formas de «deber». Unas son condiciones para alcanzar ciertos fines y son, por tanto, «meramente hipotéticas», mientras que hay una forma de «deber» que está ligada a un fin último, el cual es (moralmente) obligatorio perseguir" (Ferrater Mora, 1979: 126-127).

Por ello José Ferrater Mora indica ante la presencia de dicotomías, internadas en los paradigmas empleados, la aparición de imposibilidades y las diferencias entre las posibilidades presentes:

"Dentro del paradigma en el cual se han presentado las varias dicotomías indicadas, la separación de referencia resulta ineludible. No se puede pasar de las realidades y de los actos, de las situaciones o estados de hecho, de las costumbres y modos de comportarse, etc., a los deberes, porque se ha empezado por hacer los primeros relativos y los segundos absolutos" (Ferrater Mora, 1979: 127).

Para sostener posteriormente, sin ánimo reduccionista, que la conclusión de muchos de estos senderos ya es conocida por el intelectual catalán, informando sobre los antagonismos a encontrar en tal empresa:

"Por tanto, cualquier intento de ser y deber ser desemboca a menudo en la absorción de uno por el otro. La absorción del deber ser por el ser conduce a un «naturalismo». La absorción del ser por el deber ser conduce, mínimamente, a un "deontologismo» y máximamente a un «idealismo»-un idealismo a la vez ético, epistemológico y metafísico-. En el primer caso, eliminamos todo deber ser en cuanto «absoluto deber ser», esto es, en cuanto deber ser «incondicional», pero en la medida en que suponemos que una moral se funda en tal deber ser incondicional, eliminamos la posibilidad de una moral. En el segundo caso, hacemos del llamado «ser», como al parecer quería Fichte, una serie de obstáculos que el sujeto moral interpone en su propio camino con el fin de derribarlos. Así, sólo dos posibilidades parecen ofrecerse cuando se empieza por distinguir entre el ser y el deber ser, o entre el mundo natural y el mundo moral, según la concepción tradicional esbozada: o se mantiene esta distinción de un modo tajante, o si se aspira a eliminarla se lleva a cabo mediante la reducción completa de un término al otro" (Ferrater Mora, 1979: 127).

Para José Ferrater Mora entonces será posible el alegato de que existe otra posibilidad: la de admitir que 'el ser' y el 'deber ser' coexisten en estado de tensión constante. A lo que considera: 
"Ello puede querer decir dos cosas. Una, que hay un conflicto dialéctico entre ser y deber ser que se expresa posiblemente en el curso de la historia humana. La otra, que, dado un estado de cosas por ejemplo, una sociedad regida por ciertas normas-, puede siempre preguntarse si no podrían y, en rigor, si no deberían introducirse modificaciones que dieran por resultado otro estado de cosas -por ejemplo, ciertas normas o ciertos modos de comportarse- estimado preferible al existente y a cuyo efecto el efecto de cosas existente representa un obstáculo que debe franquearse" (Ferrater Mora, 1979: 127-128).

Por tales razones presentes en dicho "conflicto dialectico", conflicto verdaderamente histórico y las consideraciones a tomar frente a estas situaciones, el catedrático considerará que:

"La primera de las dos cosas mencionadas me parece demasiado vaga y espectacular, tanto si la tensión de referencia es constante y no queda nunca resuelta como si se procura resolverla con una especie de reconciliación más o menos metafísica. En virtud de ésta, acaba por reconocerse que todo lo que «es» en un momento pertinente, dentro del curso de la historia, y acaso del cosmos entero, debe ser justa y precisamente lo que es, o como es. Esto equivale a sostener que todo lo que debe ser, es en su debido momento -o, hegelianamente, que todo lo real es racional y que todo lo racional es real-. La segunda de las dos cosas mencionadas me parece más aceptable, pero entonces no es menester introducir ningún marco dramático o ningún escenario grandioso. En rigor, no es menester hablar entonces ni siquiera de «ser»y de «deber ser», con el consiguiente peligro de reificar estas expresiones. Por este motivo, introduciré de nuevo la cuestión de la «separación» de referencia en forma menos aparatosa: la forma hoy asimismo también ya clásica, de la relación, of falta de relación, entre 'es' y 'debe'”, (Ferrater Mora, 1979: 127-128).

Para continuar ampliando el panorama sobre la influencia del existencialismo y la filosofía existencial presente en el sistema de pensamiento de José Ferrater Mora, es importante seguir explorando los conceptos, tópicos $\mathrm{y}$ temas que demarcan la caracterización de su obra, si se entiende que él propulsa su sistema filosófico integracionista a partir de sus respectivas consideraciones sobre el "ser", abordado en al menos una decena de sus libros publicados, y, más expresamente en su Diccionario de filosofía, en este caso la lectura del concepto de "Ser", no en su totalidad, pero sí de forma integral, abarcando la evolución del término desde lo etimológico, ontológico y existencial:

"SER. 1) Nombre y concepto. El concepto de ser, que ha ocupado un lugar central en el pensamiento de muchos filósofos tiene muy diversos aspectos, entre otras razones por los modos en que se ha expresado lingüisticamente. Algunos hablan de 'ser', otros de 'el ser' ( o el Ser), otro de 'es'. Gran parte de los análisis y especulaciones en 
torno al "concepto de (l) ser" a partir de Grecia giran en torno a usos de 'ser' y 'es' en griego Eival es el infinito del verbo 'ser' y se traduce por 'ser' en español, correspondiendo en otras lenguas a essere (latín), être (francés), sein (alemán), to be (inglés). Los griegos usaron asimismo la sustantivación verbal tò őV (literalmente 'el siendo', 'el que es'), traducida frecuentemente al español por 'ser' o 'el ser', correspondiendo en otras lenguas a essere y, según los casos, a ens (latín), a être (francés), a das Sein (alemán), a Being [literalmente, 'siendo'] (inglés). Se usó ćot'́, que se traduce por 'es', $y$, en otras lenguas, por est (latín), est (francés), ist (alemán), is (inglés)" (Ferrater Mora, 2004: 3245).

Estas descripciones completamente etimológicas sobre el concepto del ser permiten la ubicación en las consideraciones del lenguaje que luego dan propiedades a la ontología del ser, ya que los conceptos filosóficos en muchos casos parten de enunciados lingüísticos, José Ferrater Mora consiente de tales implicaciones inquiere: “¿Qué pueden decir los filósofos sobre el lenguaje que no lo hayan dicho, o puedan decirlo, los lingüistas, psicólogos, sociólogos, antropólogos, etc.?” (2004).

Esta pregunta es una variante de muchas otras: “QQué pueden decir los filósofos sobre el hombre que no puedan decirlo los biólogos, arqueólogos, economistas, historiadores? ¿Qué pueden decir los filósofos sobre el mundo físico que no puedan decirlo los físicos, químicos, geólogos, astrónomos?” (Ferrater Mora, 1970: 9).

Sin embargo, la consideración expresada en el Diccionario de filosofía, en lo que respecta al lenguaje, lo etimológico y lingüístico es somero y por lo tanto José Ferrater Mora concede más amplitud a lo ontológico y existencial como se observa a lo largo del desarrollo del concepto que está en análisis:

"Desde muy temprano se planteó la cuestión de si hay que entender 'ser' en el sentido de la cópula o en el llamado «sentido existencial». $\mathrm{Si}$ 'ser' es entendido como cópula entonces requiere la mención de alguna propiedad, cualidad, relación, etc. En 'x es blanco', 'es' expresa el hecho de que $x$ es blanco (como algunos dirían, «la blancura» de $x$ ). No se puede entonces decir simplemente 'es', porque como se ha advertido a veces, cabe preguntar «¿qué?» (si se dice 'x es' se puede preguntar «¿qué es?», y responder, por ejemplo, 'blanco'). Si 'es' es entendido en sentido existencial, entonces se entiende por 'es' algo así como "existe»; ' $x$ es' quiere decir en este caso 'x existe'. Pero para decir que x existe no es menester decir que es; se puede decir, por lo pronto, que existe, y se puede decir asimismo que "hay $x »$, esto es, cuantificar $x$ existencialmente (o particularmente). Si se parte del sentido existencial de 'es', entonces parece que cabe pasar a un sentido existencial de 'ser'. Es justamente lo que ocurre cuando se habla de «el ser» (o hasta de «el Ser»), 
significándose con ello lo que existe, el «siendo»o «ente»" (Ferrater Mora, 2004: 3246).

José Ferrater Mora hace la transición de lo etimológico a lo lingüístico abarcando lo sintáctico y semántico al citar a Charles H. Kahn, considerando pertinente el carácter lingüístico para ahondar en la naturaleza de un concepto ampliamente usado en la filosofía, sobre todo en las corrientes existenciales:

"Charles H. Kahn (cfr. bibliografía infra) ha expresado la opinión de que, lingüisticamente hablando, es inadmisible la dicotomía tradicional entre los usos predicativos (el 'es' de la cópula) y existencial de 'ser' (del verbo 'ser') porque ello equivale a confundir una distinción sintáctica legítima (la que se da entre las construcciones absoluta y predicativa del verbo) con un contraste semántico entre el significado 'existir' y algún otro significado o ausencia de significado. "Esta fusión del criterio sintáctico y del criterio semántico en una antítesis simple podría justificarse únicamente si hubiera una correlación directa entre los dos, es decir, sólo si 1) el uso absoluto del verbo fuera siempre existencial en significado, y 2) el verbo 'ser' en la construcción predicativa estuviese siempre desprovisto de significado, sirviendo de recurso meramente formal o gramatical para enlazar el predicado del sujeto»" (Ferrater Mora, 2004: 3246).

Sin embargo, no se detiene en abarcar su fundamentación sobre los postulados en torno al lenguaje, ya que prosigue su abordaje desde la ontología, incluyendo inicialmente la ontología aristotélica:

"Por otro lado, sin embargo, Aristóteles habla de la filosofía primera como aquella que se ocupa de «el ser», y aunque ello puede entenderse también como la ciencia que se ocupa de los diversos modos como se puede entender 'es', ha habido distintas interpretaciones del 'ser como ser' o 'es como es' aristotélico. A estas interpretaciones nos referimos luego. Por el momento, nos confinaremos a dos puntos. Uno es que aunque la distinción entre el 'es' predicativo y el 'es' existencial puede no tener su origen en los usos griegos, una buena parte de la tradición filosófica ha partido de estos usos, o supuestos usos, de modo que no hay más remedio que reseñarla. El otro es que dentro de esta tradición filosófica ha habido numerosos modos de entender lo que se ha venido a llamar «el ser»: el ser como ente, el ser como la substancia" (Ferrater Mora, 2004: 3246).

La peculiaridad de José Ferrater Mora respecto a la forma en la que se interpreta la tradición filosófica incluyendo la aristotélica, ha sido objeto de múltiples interpretaciones. Entendiendo que lo señalado no demarca ningún territorio o corriente filosófica en sí, las interpretaciones que suelen hacerse se orientan a fundamentar algún tipo de corriente partiendo de una génesis ontológica, que tiene sus referentes en estas tradiciones y que 
reconoce tributar a Aristóteles, referencialmente a los sistemas filosóficos que se orientan al pensamiento de "el ser", entendido como ente, "el ser" como substancia, desde donde parten las raíces de la diversidad de corrientes existencialistas y por qué no expresarlo, también los antiexistencialistas y como lo menciona José Ferrater Mora en su concepto sobre existencialismo, los que desde el existencialismo pretenden superarlo.

Volviendo al desarrollo del artículo sobre "Ser", José Ferrater Mora insiste en hacer la invitación a seguir con la lectura los clásicos griegos -su óptica integracionista le permite la interacción de pensadores destacados de la antigüedad helénica, sin diferenciar entre socráticos o presocráticos-:

"Pasemos ahora al concepto del ser. Este concepto está por lo menos implícito en el primitivo preguntar griego del cual hablaremos en la segunda sección del presente artículo. Explícitamente se manifiesta en la interrogación tí tó öv, que se traduce ¿¿Qué es el ser?', pero que podría más justamente traducirse en este caso por '¿Quién es el ser?', esto es ‘¿Cuál es la cosa que propiamente es?'. Con esto pensaron que el ser es un atributo que pertenece a todo lo que es en el mismo sentido. Se ha dicho que con ello se confunden proposiciones del tipo ' $x$ es', pero no es justo siempre suponer que habia en la mente de los griegos semejante confusión. En efecto, algunos pensaron que el ser del que se hablaba era algo más general que ninguna substancia determinada, tan general, en rigor, que no era posible decir de él otra cosa que 'es'. Es el problema de Parménides. Fue dilucidado a fondo por Platón y luego, sobre todo, por Aristóteles cuando estos filósofos advirtieron que el hecho de que «ser» sea un concepto general no significa que sea el más elevado de todos los géneros" (Ferrater Mora, 2004: 3247).

Se observa entonces que la naturaleza del concepto "ser" no era un tema que se sitúa sobre los diversos géneros de concepto que los griegos consideraban en sus tradiciones filosóficas, al menos como se ve expresado desde los presocráticos y posteriormente en Platón y Aristóteles. No se encuentran discusiones o exposiciones de corrientes filosóficas exclusivistas en el concepto "ser", o al menos si tiene un carácter que lo distingue, no era preminente, ya que al parecer estaba colocado junto a los otros géneros sin estar por encima de ellos:

"Aristóteles sobre todo percibió claramente que concebir el ser como la clase de todas las clases conduce a contradicciones (la contradicción sobre las clases a que nos hemos referido en Paradoja [VÉASE] y que ha sido puesta de relieve por la lógica contemporánea). Por lo tanto, parece que haya que adoptar sobre el ser un punto de vista distinto del cosmológico y del lógico: el «punto de vista metafísico». Con la «filosofía primera» Aristóteles inició la discusión en torno al problema del ser. El «ser como ser», őV ஸ़ őV, aristotélico puede ser interpretado de dos maneras. En la primera, el 
ser es el ser más común de todos, válido para todos los entes y poseyendo, por consiguiente, la extensión máxima. En la segunda, el ser es el ser superior a todos y principio de todos" (Ferrater Mora, 2004: 3247).

Es Aristóteles quien demarca desde su filosofía primera, una adopción a la concebida por sus antecesores griegos quienes habían desarrollado sus visiones del ser desde la cosmología y la lógica. Esto conduce a dos interpretaciones como se ve expresado al final del fragmento que se está considerando, mostrando así que la ontología aristotélica marca un antes y un después en la percepción filosófica griega de "ser" y "el ser".

Entre los capítulos que integran De la materia a la razón, resulta llamativo por lo contenido en sus diferentes partes más de un subcapítulo; a continuación será abordado del Capítulo 1. Titulado "Realidades"; el subcapítulo número quinto, denominado: "E1 continuo físico-orgánico", ubicado entre las páginas 38 y 41.

Entre las primeras afirmaciones de José Ferrater Mora se encuentra: la improbabilidad de la existencia de alguna materia orgánica -significando bajo este adjetivo: "viva", con capacidades y propiedades biológicas- "distinta de la inorgánica" (1979: 38), informando que hasta la fecha -año 1979- además de improbable, se muestra imposible tal materia. Sostiene José Ferrater Mora con esto, que ambos opuestos constituyen de este modo un continuo, pasando a aclarar la equivalencia de tal concepción: “a) que la materia llamada inanimada es sede de actividades que, organizadas de ciertos modos, dan lugar a reacciones químicas; dadas ciertas condiciones, y específicamente “ciertos procesos de autoensamblaje” (1979: 39), se suscitan procesos orgánicos; "b) los organismos equivalen a entidades físicas con sus respectivas "propiedades-funciones", aunque organizados en correspondencia a "otro sistema de propiedades-funciones" (1979: 39) y por último “c) donde se enfatiza la consideración a los modos operacionales interorgánicos. Sentenciando más adelante sobre la "continuidad de lo físico con lo orgánico" manifiesto "en el de la producción de lo que se llama «la vida» a partir e la «materia inorgánica»" (1979: 39). Expresando así por la interrelación de dependencia, entre la existencia de un determinado ente o nivel y otro de similares características.

José Ferrater Mora observa la vida desde sus diversas realidades, y esas realidades que están conectadas con lo orgánico e inorgánico, que transitan de la materia a la razón, sin duda alguna poseen elementos académicos, ya que la academia contiene un saber que responde a una historia del pensamiento. Sin embargo, en el escritor catalán también 
prevalecen los elementos existenciales como primordiales a la hora de hacer o exponer su método filosófico, siendo el integracionismo una forma existencial de percibir las realidades, entre ellas la vida y la muerte.

15.2. Historia y drama de la existencia humana: la muerte que da sentido a la vida.

La vida -escribió Aristóteleses aquello por lo cual un ser se nutre, crece y perece por sí mismo.

José Ferrater Mora.

La muerte se dice de muchas maneras.

José Ferrater Mora.

La concepción ferrateriana acerca de la historia y el drama de la existencia humana es entendida como una muerte o cesación que otorga sentido a la vida. En su título El ser y la muerte (1962), ya el autor profería, claras formulaciones relativas al ser "mortal", enumerando las siguientes proposiciones:

“1) Ser real es ser mortal; 2) Hay diversos grados de mortalidad,
desde la mortalidad mínima a la máxima; 3) La mortalidad
mínima es la de la naturaleza inorgánica; 4) La mortalidad
máxima es la del ser humano; 5) Cada uno de los tipos, de ser
incluidos en la realidad', es comprensible y analizable en virtud
de su situación ontológica dentro de un conjunto determinado por
dos tendencias contrapuestas: una que va de lo menos mortal a lo
más mortal y otra que recorre la dirección inversa» (op. Cit., p.
9). Lo que se llama «muerte» es entendido aquí como un
fenómeno, o una «propiedad», que permite «situar« " tipos de
entidades en el citado «continuo de la Naturaleza»” (Ferrater
Mora, 1979: 2473).

Multiplicidad de direcciones sirven de base teórica a esta construcción integral de la noción de muerte legada por José Ferrater Mora. Reelaboración incesante a lo largo del tiempo, desde aproximadamente los años treinta y cuarenta, hasta su repentina muerte a principios de los años noventa, la muerte representaba otro importante acceso al profundo ser existencial, pensador inagotable y de igual modo lector, que atento a los detalles más variados, se atrevió a concluir sobre este tema, diciendo:

"Ahora bien, ninguna de estas concepciones entiende la muerte en un sentido suficientemente amplio, justamente porque, a nuestro entender, la muerte se dice de muchas maneras (desde la cesación hasta la muerte humana), de tal modo que puede haber inclusive 
una forma de muerte específica para cada región de la realidad"

(Ferrater Mora, 1979:2473).

De esta manera José Ferrater Mora ratifica finalmente en su Diccionario de filosofía, la concepción de la muerte desde el aspecto histórico y dramático. Es preciso atender las consideraciones ferraterianas en relación al otro lado de su propuesta, es decir a la vida que ha captado su sentido de la cesación. Al acudir nuevamente al célebre Diccionario de filosofía, se hallarán las siguientes reflexiones:

"Muchos filósofos antiguos distinguían entre la vida como vida «orgánica», entendida asimismo como el principio vital o «vitalidad»; y la vida como la manera en que vive el hombre. A la primera

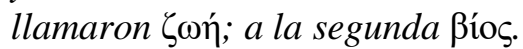

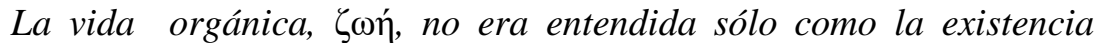
biológica. En la medida en que la Naturaleza está «animada», es «viviente»y, en este sentido, es «orgánica». Dentro de la vida orgánica, entendida en este amplio sentido, se halla el ímpetu, $\theta 0 \mu$ ós, y también el alma, $\psi v \chi \eta ́$, como principio del movimiento de cada ser viviente." (Ferrater Mora, 2004: 3689).

Entre las diferenciaciones introductorias presentadas por José Ferrater Mora, se

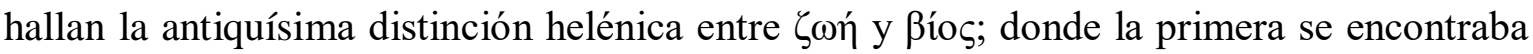
relacionada con lo orgánico de la existencia, sinónimo de "vitalidad", y, en el término segundo como modus de vida:

"La vida como modo humano de ser era principalmente la vida «práctica». Esta incluía asimismo a la vida «moral», entendida como el vivir de acuerdo con las mejores costumbres y normas de convivencia social. El término, Bíos puede entenderse hasta

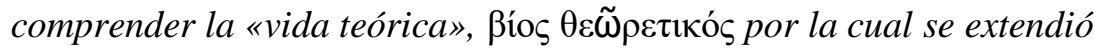
la más alta forma de vivir." (Ferrater Mora, 2004: 3689).

Aclarada esta concepción de vida como inclusiva de la existencia en su carácter plenamente pragmático, aunque acompañada de los aspectos morales, tales: "costumbres", reglas de coexistencia derivan en altas y paradigmáticas formas de vida:

"A despecho de la mencionada distinción, los filósofos antiguos no separaban, como se hizo luego, la vida biológica de la vida «mental». «La vida-escribió Aristóteles- es aquello por lo cual un ser se nutre, crece y perece por sí mismo» (De anima, II, 1, 412 a, 10-20). El estudio de la vida no pertenece, según ello, a la física ni a la historia natural, sino a la «psicología». Pero, a la vez, la psicología no era, como para nosotros, una ciencia e cierta realidad o de unos ciertos comportamientos, sino el saber acerca de lo que es forma y principio de realidad en los seres vivientes. Por eso desde el primer instante la vida aparece bajo dos aspectos: es vida del cuerpo -de un cuerpo más «psíquico» que el puramente material- y es vida del alma -de un alma más «corporal que el puro espíritu-. Por eso el alma, escribe 
Aristóteles, es «el primer grado de actualidad de un cuerpo natural que posee en él, potencialmente, la vida». La vida es, en suma, algo que oscila entre un «alma»y un «cuerpo»y, además, lo que hace posible crear el ámbito dentro del cual se da la unidad de ambos «extremos»." (Ferrater Mora, 2004: 3689).

Encuentros y desencuentros etimológicos iluminan el sendero por donde han transitado las distancias reflexiones acerca de la vida, desde sus diferencias fundacionales, hasta las relaciones reverberantes que a partir de su genealogía más profunda, han logrado soportar el desafío del tiempo para persistir hasta la actual conceptualización. Ejemplo de ello es la interiorización:

“La noción de «vida» experimenta, especialmente en ciertas tendencias, un proceso de «interiorización»: ya en Plotino la vida «asciende» hacia lo espiritual. En los neoplatónicos sucesores de Plotino esto es todavía más evidente. Recogiendo algunas insinuaciones de Platón, según el cual la vida caracteriza también lo Uno, Plotino habla de una relación entre lo Uno, la vida y el nous. Y en Proclo la Vida es ya el segundo término (lo Uno, la Vida, el Nous) de una triada correspondiente a la segunda hipóstasis. "Todas las cosas que participan de la Inteligencia -escribe Proclo- son precedidas por la Inteligencia no participada. Las que participan en la Vida, son precedidas por la Vida, y las que participan del Ser, son precedidas por el Ser. De estos tres principios no participados, el Ser es anterior a la Vida, y la Vida es anterior a la Inteligencia» (Institutio Theologica, prop. 101).” (Ferrater Mora, 2004: 3689-3690).

Ascensión a lo espiritual desarrollada por Plotino, línea continuada por los neoplatónicos, quienes desde sus doctrinas asumen tales tesis; luego intervendrá Proclo con la tríada: Inteligencia, Ser y Vida. De modo que laborará sobre las diferentes posibilidades de interrelación de dichos elementos:

"Lo que participa de la Inteligencia, participa, pues, de la Vida, pero no a la inversa, ya que hay, dice Proclo, muchas cosas vivas, pero vacías de conocimiento. "Todo lo que vive -sigue diciendo Proclotiene movimiento propio a causa de la vida primaria» (prop. 102). Y «todas las cosas están en todas las cosas, pero en cada una según su propia naturaleza. Pues en el Ser hay Vida e Inteligencia; en la Vida, Ser e Inteligencia, en la Inteligencia, Ser y Vida. Pero cada uno éstos existe sobre un nivel, intelectualmente; sobre otro, vitalmente; sobre el tercero, existencialmente» (prop. 103). La Vida queda aquí decididamente hipostasiada de modo que puede hablarse inclusive de una «Vida primaria». Lo mismo, y a mayor abundamiento, ocurre con los últimos neoplatónicos. La Vida como dynamis fue en Porfirio, en Jámblico, en Siriano, el segundo término de una tríada situada entre el Ser y la Inteligencia en un sentido parejo se expresó el PseudoDionisio. Y algo análogo habían enunciado los sistemas del gnosticismo, especialmente cuando hablaron de la Vida como algo engendrado, junto con el Logos, por la conjunción de la Verdad y de 
la Inteligencia. Desde el punto de vita terminológico, tenemos aquí la Vida como una, a diferencia del sentido antiguo y casi puramente orgánico-viviente de este vocablo. El uso del término en los escritos neotestamentarios se mueve dentro de un horizonte que, aunque inevitablemente distinto, se acerca más a los supuestos anteriormente enunciados que a los que corresponden a las primeras fases de la concepción griega de la vida. La vida es entendida muchas veces como vida eterna, como «vida de espíritu» y del «cuerpo espiritual». Pues cuando la Vida resucita finalmente, reaparece no sólo el

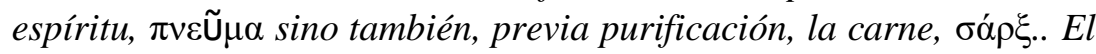
Camino, la Verdad y la Vida son las hipóstasis del Logos en el cual estaba la Vida «como la verdadera Luz que ilumina a todos los hombres» (S. Juan, I, ix). Y en un pasaje de San Pablo (Heb., IV, 12)

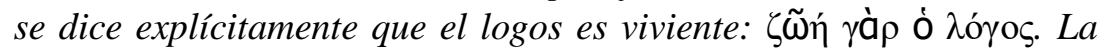
vida puede ser, así, no sólo el principio de todo lo viviente, sino lo que salva a lo viviente de la aniquilación y de la muerte." (Ferrater Mora, 2004: 3690).

Concluidas las apreciaciones espirituales sobre el Logos, es de esperar una relación dialéctica entre cada periodo o etapa histórica, llegando de este modo la oportunidad para que la Edad Media ejerza su labor, con sus respectivos desafíos reflexivos sobre tal cuestión:

"Durante la Edad Media persistió este sentido hipostático de 'Vida', pero, especialmente bajo la influencia de Aristóteles, volvió a considerarse la noción de «vida» desde un punto e vista orgánico entendido en un sentido bastante amplio-. Santo Tomás afirma que llamamos «vivir» a lo que posee por sí mismo un movimiento o sus correspondientes operaciones ( $c f r$. De veritate, $I V$, 8). Vida es lo que puede moverse por sí mismo, es decir, la sustancia a la que conviene, según su naturaleza, moverse a sí misma. (S. theol. I, q. XVIII, arts. l, 2). La vida orgánica es concebida a menudo como la vida entendida «en acto segundo» a diferencia de la actividad del alma, que es vida entendida «en acto primero»." (Ferrater Mora, 2004: 3690).

En un primer nivel la perdurabilidad del sesgo hipostático, enmarcada en la fuerte e inmediata influencia aristotélica, que conllevarían a una reconsideración de la noción de "vida" desde una óptica orgánica, aunque esta vez de mayor amplitud, serían algunas de las tantas ideas potenciadas entre otros pensadores:

"En el Renacimiento se desarrolló el concepto de «vida en un sentido muy amplio, correspondiendo a la idea de un principio que mueve todas las realidades, e inclusive el mundo entero concebido, como lo había sido ya por los estoicos y algunos neoplatónicos, como «un gran animal» o «gran organismo». Vida orgánica y vida psíquica fueron con frecuencia identificadas. Se desarrollaron numerosas corrientes panvitalistas y al mismo tiempo pampsiquistas." (Ferrater Mora, 2004: 3690). 
Gran efervescencia caracterizó al ciclo renacentista, el concepto de vida no escapará a tales cambios y en consecuencia experimenta su mayor esplendor, asumiéndose como gran rector de realidades. Planteamientos que cuentan con claros precedentes en el estoicismo y el neoplatonismo, más no con el alcance o irradiación experimentado en este nuevo contexto, resplandor que encuentra su ocaso:

"Estas corrientes perdieron influencia cuando, con Descartes, se procedió a distinguir entre el pensamiento y la extensión. Los seres vivientes no tienen otras propiedades que las propiedades mecánicas. El «vitalismo» (Véase) fue arrumbado en gran parte en favor del mecanismo. Se ha hablado por ello de la «concepción mecanicista de la vida» como concepción predominante en la época moderna, desarrollada no sólo por dualistas -para quienes hay, por una parte, el «mentalismo» de la subsistencia pensante y, por la otra, el «mecanicismo» de la substancia extensa-, sino también por materialistas -que trataron de reducir todos los fenómenos vitales a fenómenos físicos, y especialmente mecánicos-. Max Scheler ha descrito -y, de paso, criticado- esta concepción moderna mecanicista de la vida. Para la época moderna a partir de Descartes, afirma Scheler, la vida no es ya un «fenómeno primario» sino sólo un complejo de procesos mecánicos y psíquicos. «En la concepción mecanicista de la vida -escribe Scheler-el ser viviente es concebido bajo la imagen de una 'máquina'; su 'organización' es considerada como una suma de instrumentos útiles, que sólo se diferencian por su grado de los producidos artificialmente. Si esto fuera exacto, la vida ya no podría tener, naturalmente ningún valor substantivo, distinto de los valores utilitarios, esto es, de la suma de los valores utilitarios que corresponden a estos 'órganos'; y la idea de una técnica vital substantiva, distinta en principio de la técnica mecánica, resultaría absurda, ya que exigiría el desarrollo de facultades opuestas a la que sirven para la técnica mecánica." (Ferrater Mora, 2004: 3690-3691).

La irrupción de René Descartes brindará el vuelco necesario para la natural evolución teórica. Mecánica versus biología maquina versus ser:

"Paralelamente a esto va el principio -triunfante en la biología moderna hasta el punto de parecer ya evidente- de que todas las exteriorizaciones, movimientos y acciones del ser vivo, así como los órganos y mecanismos inervadores, sólo se desarrollan y transmiten, en cuanto son 'útiles', esto es, en cuanto tienen un cierto valor para la conservación de la máquina humana» (El resentimiento en la moral, trad. J. Gaos, 1938 pág. 213). Esta descripción y valoración -negativa- de la «concepción moderna» (mecanicista) de la vida (orgánica) se ha resumido a veces con los rasgos siguientes: 1) El conjunto viviente es una suma de sus partes, 2) el órgano es representable en forma de instrumento fabricado con lo inerte, 3) los procesos de crecimiento y desarrollo se reducen a tendencias de conservación; 4) el organismo corporal no es sustentáculo de fenómenos vitales, sino que la vida es una propiedad de las materias y 
fuerzas las que componen el organismo." (Ferrater Mora, 2004: 3691).

Llegado el siglo veinte, se tendrá que definir una postura en relación a tan ineludible reflexión. Ferrater Mora en base a los cuatro rasgos anteriormente descritos enunciará una concepción moderna, que profundiza en dialogo con el fílósofo germano Max Scheler:

"Aunque, como se indicó, las concepciones mecanicistas arrumbaron en las concepciones «vitalistas», ello no tuvo lugar con el radicalismo que Scheler describe, ni tuvo las desastrosas consecuencias que proclama. Por un lado, hubo numerosas investigaciones biológicas. Floreció también la llamada «historia natural», con importantes trabajos de clasificación de animales y plantas. Por otro lado, hubo filósofos que, como los platónicos de Cambridge y Leibniz, propusieron y desarrollaron sistemas conceptuales distintos de, o no completamente subordinados al, mecanicismo. Finalmente, la filosofia natural de autores como Schelling, Oken, Steffens, Baader y otros exhibió fuertes rasgos «organicistas». Algunos de estos desarrollos -como sucede con el último mencionado-tuvieron para la filosofía y, en la medida en que la alcanzaron, para la ciencia las desastrosas consecuencias que Scheler adscribe a un supuesto imperio completo del mecanicismo; trataron de sustituir éste por un dudoso vitalismo especulativo. Otros, como los trabajos biológicos y las investigaciones de «historia natural», fueron llevados a cabo sin por ello perjudicar el desenvolvimiento del mecanismo y del corpuscularismo. No es seguro que se produjera, como Whitehead ha proclamado, y lamentado, una «bifurcación de la Naturaleza»." (Ferrater Mora, 2004: 3691).

Max Scheler a diferencia de los tres pensadores citados con anterioridad, distanciará igual número de aspectos, en aras de establecer sólidas relaciones entre valores "vitales" y valores "espirituales", con el propósito de ubicar los factores de superioridad e inferioridad enfrentados entre cada uno de estos extremos:

"Scheler distingue entre lo psíquico, lo vital y lo espiritual, que forman tres órdenes de la existencia humana dispuestos en jerarquía: hay que reconocer los valores vitales y admitir que son distintos de los espirituales, pero a la vez hay que admitir que los últimos son superiores a los primeros. En todo caso, lo vital es para Scheler siguiendo en esto a Nietzsche, una realidad ascendente, un valor irreductible a la utilidad, a los valores de lo agradable $y$ desagradable. Whitehead manifiesta defender una doctrina según la cual «ni la naturaleza física ni la vida psíquica pueden ser entendidas a menos que las fusionemos como factores esenciales en la composición de cosas 'realmente reales' cuyas interconexiones y caracteres individuales constituyen el universo» ("Philosophy of Life, en Dagobert D. Runes, ed., Twenty Century Philosophy, 1943, pág. 142)." (Ferrater Mora, 2004: 3692). 
Scheler al parecer continuador de los preceptos nietzscheanos, afirmará como vital al valor en ascenso. Whitehead abogará por la fusión de la naturaleza en aras de la constitución del universo posible gracias a tal conjunción. Concluyendo José Ferrater Mora sobre tal conjunto de filosofías:

"Las filosofías precedentes son a veces caracterizadas, o clasificadas, como «filosofías de la vida»; incluyen temas de filosofía orgánica, pero también, y a veces sobre todo, una teoría de los valores. Aunque ocasionalmente rozan las cuestiones planteadas en las disputas entre mecanicistas y vitalistas, son de tipo distinto de las reflexiones sobre la vida como objeto de las ciencias biológicas, del tipo de las que encontramos por ejemplo, en Ervin Schrödinger cuando afirma que la dificultad, sino la imposibilidad, de reducir los fenómenos biológicos a un determinismo mecanicista se debe principalmente a dos hechos: a que el gene contiene un número relativamente escaso de átomos para poder ser sometido a las leyes estadísticas de las estructuras físico-químicas y a que posee un alto grado de estabilidad. Por eso, dice Schrödinger, mientras el orden de la físico-química es «el orden del desorden» (de naturaleza estadística), el orden de la biología es «el orden del orden» (de naturaleza dinámica) (What is life?, 1946 [2. ed., 1956], trad. Esp.: ¿Qué es la vida?, 1947).” (Ferrater Mora, 2004: 3692).

Filosofías de la vida, corriente filosófica en la que se agrupa a mecanicistas y vitalistas, con por ejemplo reflexiones biológicas que abarcan territorios alejados de la ciencias de la naturaleza, ordenativas sobre el orden y el desorden (estadísticas y/o dinámicas):

"Hay otras corrientes filosóficas, a menudo agrupadas bajo el rótulo "filosofía de la vida», que entienden 'vida' en sentidos a veces similares a algunos de los mencionados y a veces muy distintos. Un ejemplo es el de Dilthey, que trata de superar por medio de una «filosofía de la vida» el relativismo a que parecen conducir las distintas concepciones del mundo. Subyacente a estas concepciones es la vida misma, la actitud que ésta adopta ante el mundo y ante sí misma. La vida es, según Dilthey, el tema capital de la filosofía. Para Simmel la vida es un paso necesario para llegar a una interpretación del ser. Heidegger, que tiene presentes estas formas de Lebensphilosophie, indica, sin embargo, que Simmel advierte la diferencia que se percibe de algún modo ya en Dilthey: la que hay entre el aspecto biológico-ontológico y el aspecto ontológico-existenciario." (Ferrater Mora, 2004: 3692). 


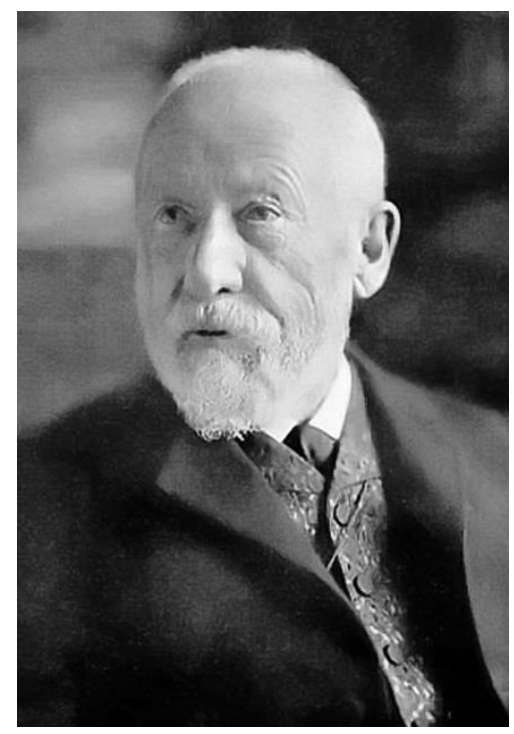

Ilustración 17: Wilhelm Dilthey. Tomado de: https://www.thefamousbirthdays.com/people/wilhelm-dilthey

Corrientes del pensamiento denominadas por sus intereses comunes, aunque trabajen sus enfoques desde posturas y métodos contrarios, como el de Wilhelm Dilthey destacado por José Ferrater Mora, recordando que para el pensador alemán, la vida pasa a ser posicionada como el tema capital de la filosofía, planteamiento que lograría influenciar otras tendencias filosóficas, identificadas como "filosofía de la vida" o la "filosofía del espíritu”. El mismo que es tomado en otros sentidos, aspirando a evolucionar sobre los preceptos ya establecidos:

"En muchos casos la vida se entiende como «vida humana», pero se da a 'vida' un sentido metafisico que no se encuentra en las ciencias humanas. Para Ortega y Gasset, la idea de la vida, especialmente como «mi vida», aspira a superar el nivel en que se movían las anteriores concepciones acerca de la vida y tiende a hacer de ésta el objeto metafísico por excelencia. Según Ortega y Gasset, vivir es encontrarse en el mundo, hallarse envuelto y aprisionado por las cosas en cuanto circunstancias, pero la vida humana no es sólo este hallarse entre las cosas como una de ellas, sino saberse viviendo." (Ferrater Mora, 2004: 3692).

Vivir pasa con José Ortega y Gasset por reconocerse dentro del mundo, sabiéndose vivo, asumiéndose ser viviente, visión exclusivamente orientada -y a raíz de la postura asentada- en la perspectiva de una vida individual, "mi vida", consideración existencialista, con profundidades ontológicas, pero resultante de la experiencia vital, señalando en base a ello:

"De ahí que siendo el vivir un verse vivir, la vida humana sea ya un filosofar, esto es, algo que la vida hace en el camino emprendido para llegar a ser sí misma. La inserción de la filosofía y del pensamiento en la vida no es, pues, algo que acontece en virtud de una supuesta 
consubstancialidad de la vida con la razón, sino el resultado de una experiencia de la vida. Ésta es algo anterior y previo a lo biológico y aun a lo psíquico, que son circunstancias que se hallan en la vida humana. La vida no es ninguna substancia; es actividad pura. No tiene una naturaleza como las cosas que están ya hechas, sino que tiene que hacerse constantemente a sí misma. Por tal motivo, la vida es elección. En esta elección inevitable se halla el fundamento de la preocupación, del ser de la vida como quehacer, de su proyección al futuro. La vida es también, en el fondo, como la Existencia de Heidegger, tiempo, mas en un tiempo que sólo analógicamente tiene que ver con el tiempo del mundo, de las cosas, de las circunstancias. Por eso la vida no es nunca algo determinado y fijo en un momento del tiempo, sino que consiste en este continuo hacerse, en esta marcha hacia lo que ella misma es, hacia la realización de su programa, es decir de su mismidad." (Ferrater Mora, 2004: 3692).

José Ferrater Mora decide la oportuna incorporación al dialogo de otros autores, quienes ofrecerán su valioso auxilio con consideraciones que vinculan al existencialismo, la filosofía de la existencia con la filosofía de la vida, asumiendo esta última como derivada de la fenomenología:

"Según algunos autores (por ejemplo, Georg Misch, en op. cit. En bibliografía) la llamada «filosofía de la vida» (Lebensphilosophie), tal como ha sido elaborada por Dilthey, pero también por otros autores -como Simmel, Ortega y Gasset, Scheler, etc.-, es una corriente distinta tanto de la fenomenología (que, por otro lado, puede haberle prestado valioso auxilio, como sucedió con Scheler) como, y sobre todo, del existencialismo y de toda filosofía de la existencia." (Ferrater Mora, 2004: 3692-3693).

Prepara su conclusión José Ferrater Mora reconociendo la valía de las indagaciones de sus connacionales Julián Marías y José Ortega y Gasset, junto a Otto Friedrich Bollnow y Martin Heidegger en los siguientes términos, apuntan hacía la relación directa entre el existencialismo filosófico o "filosofía de la existencia" relacionado con la "filosofía de la vida"; que figuran como los conceptos colocados en comparación por José Ferrater Mora:

\footnotetext{
"Puede inclusive concluirse que en ciertos respectos la filosofía de la vida alcanza a otros estratos más básicos que la filosofía de la existencia (lo último es lo que opina Julián Marías en relación con el «racio-vitalismo» de Ortega y Gasset). Según otros autores (por ejemplo, Otto Friedrich Bollnow), la filosofía de la vida puede ser considerada como una preparación para la filosofía de la existencia y para el existencialismo. «La problemática analítico-existenciaria desarrollada por Heidegger y su escuela -escribe Bollnow en Die Lebensphilosophie, 1958, pág. I [Verständliche Wissenschaft, 16]-, con la clara elaboración de los conceptos, parece más propia [para alcanzar los fines propuestos] y aprehender con mayor agudeza lo que la filosofía de la vida había dejado sumido en una cierta falta de claridad conceptual»." (Ferrater Mora, 2004: 3693).
} 
Como se lee claramente, la filosofía de la vida, alcanza "estratos más básicos que la filosofía de la existencia", además de ser posible considerarse como preparatoria de la filosofía de la existencia. Es menester el establecimiento de conceptos, que con su uso reflexivo den pie a reflexiones históricas detalladas. Revelándose en este caso, según el uso de su método discursivo y el reconocimiento oportuno de tal variación. Sintetiza y recapitula el catedrático catalán para cerrar con lo expuesto asumiendo un trio de enunciados elementales:

"Resumiendo los diversos aspectos con que se ha presentado el tema de la vida a la consideración filosófica, tenemos: (I) La vida como entidad biológica, tratada por la ciencia y por la metafísica de lo orgánico; (II) la vida como vida práctica o como existencia moral, tema de la ética; (III) La vida como el objeto metafísico por excelencia; como aquella realidad que propiamente no es ni vale, pues constituye, el dato primario y radical en cuyo ámbito se encuentran el valer y todas las especies de ser." (Ferrater Mora, 2004: 3693). 


\section{CONCLUSIONES}

La filosofía existencial, o filosofía de la existencia, los problemas existenciales y ciertos rasgos de carácter existencialista, tienen un espacio importante en el sistema de pensamiento de José Ferrater Mora, impronta identificada diáfanamente mediante cada una de las influencias que se perciben en los análisis hechos a su obra y sus ideas a lo largo de los apartados correspondientes en este presente trabajo de grado.

Asimismo, los elementos de esa corriente de pensamiento están impresos de manera indefectible en su obra, sobre todo desde el desarrollo de sus temáticas, no es de poca valía el grupo de temas de interés del intelectual catalán agrupados en los capítulos dedicados a el Existencialismo y la filosofía existencial en José Ferrater Mora, lo que se expone sobre Existencialismo Existencial o Existencialismo Académico, también se incluye un análisis del término existencia; los cuales apuntan inequívocamente hacia ese campo filosófico denominado filosofía de la existencia, filosofía existencial y el existencialismo, e incluso, por ciertos rasgos que caracterizan a varios pensadores a quienes los especialistas califican de filósofos existenciales y existencialistas, donde hay presente similitudes y cercanías.

Desde la introducción realizada sobre el Existencialismo, se puede observar algo evidente y es lo significativo que fue y sigue siendo como movimiento filosófico. Tanto los temas que definen al existencialismo, como las diversas corrientes relativas al pensamiento existencial y sus destacados exponentes, sin duda reflejan una situación común y esta es la existencia individual (Comte-Sponville, 2003: 214). José Ferrater Mora a través de su trabajo enciclopédico y académico ha sido permeado por estas corrientes interesadas en el ser, dedicando parte importantísima -tanto desde el punto cuantitativo como cualitativode sus faenas a reflexionar y establecer comparaciones entre los elementos que configuran el corpus existencial.

Su componente biológico, poseedor de conciencia y además con capacidad para recrear o crear aquello que pasa por su pensamiento -o lo que su imaginación puede ingeniar y luego materializar. Tal existencia individual tiene un principio y un fin o "cesación". Una existencia individual que va cambiando y donde sus cambios no sólo obedecen a lo biológico, también a lo metafísico, a lo racional. Existencia ante la cual también es apto el cambiar la realidad que le rodea.

Sin embargo, no todos los pensadores ven esa existencia individual del mismo modo. En el existencialismo y en la filosofía existencial se observa tantas formas de ver la 
existencia como pensadores hay. Resulta permisible decir que cada pensador es una tendencia e incluso que cada uno de ellos puede constituir movimientos y sistemas filosóficos que alcanzan hasta parecer contradictorios, solo por mencionar un ejemplo, un creyente y religioso como Sören Kierkegaard o un supuesto ateo y marxista como JeanPaul Sartre. A pesar de ese "abismo", Sartre no se sentía tan distante de Kierkegaard, como tampoco lo era Miguel de Unamuno al que se refirió como un "hermano".

Miguel de Unamuno habló en este sentido de ser cercano a otro filósofo que no era de su misma religión o siquiera pariente lejano en lo carnal. Probablemente, de Unamuno se refiere a la cercanía de pensamiento, a la cercanía filosófica, cercanía que también le pertenece al "hombre de carne y hueso" y que indefectiblemente es la cercanía que da el ser consciente de la existencia, de tener presente en la mente la existencialidad, la de tener en común el tema existencial.

Dicho "lugar común" puede distinguirse en los escritos de José Ferrater Mora, obra que a pesar de tener un carácter evolutivo, como ya se ha expuesto, -a Ferrater le gustaba revisar y reescribir sus libros-, no dejó de tener presente los elementos del existencialismo, y de forma indefectible, consideraciones de carácter existencial, donde priva la no negación de las oposiciones sino por el contrario la identificación de los polos opuestos y su consecuente confluir.

Tomando en consideración que el "integracionismo" no es un movimiento filosófico y que José Ferrater Mora jamás pretendió que lo fuera, su método para hacer filosofía no consiste en la negación o superación de un movimiento filosófico y tampoco de un sistema filosófico. Su idea es "integrar", "aunar", pero tampoco consiste en "sintetizar" o en todo caso, exponer su método como una dialéctica hegeliana. En este sentido, el experto Julián Marías en su obra Historia de la filosofía apuntó acerca del integracionismo de José Ferrater Mora que el mismo proponía tender un puente sobre el abismo con "demasiada" frecuencia abierto en el pensamiento que toma como eje la existencia humana y el que toma como eje la naturaleza, entendiendo que dicho puente no requiere una "nivelación" de las doctrinas ni un "compromiso" entre sus extremos, sino por el contrario un transitar de ambas direcciones (Marías, 1998).

A esto se agrega que José Ferrater Mora le colocó apellido a su sistema filosófico denominado "integracionismo", ya que en su obra El ser y la muerte lo enuncia como "empirismo dialéctico", cuestión que pudiera parecer contradictoria, pero desde su 
perspectiva no lo es. Precisamente de eso se trata, de tender un puente entre aquello que es opuesto o de dos corrientes o sistemas que se oponen.

En las lecturas y análisis expuestos en el presente trabajo sobre las dos obras que representan el núcleo del pensamiento del autor, como lo son El ser y la muerte: bosquejo de una filosofía integracionista y De la materia a la razón, está expresamente expuesto lo que el intelectual José Ferrater Mora afirma, pero también en lo que respecta al resto de su obra, como la lectura que se hace a su exposición sobre Lógica y Realidad.

La visión de Ferrater Mora acerca de la existencia se verá impregnada por su sistema filosófico incluso cuando está caracterizando un concepto o cuando expone un tema como el de la muerte. Su luengo exilio y las experiencias individuales que le toco sortear se harán sentir en las reflexiones ferraterianas, que marcaran la impronta en su visión en torno a la filosofía existencial, en la cual Ferrater dejará por sentado que lo que priva es el hombre que piensa y vive existencialmente y el cual se negará a reducir su ser humano o su personalidad, a una entidad cualquiera. Ferrater destaca que el ser humano no puede reducirse a ser un animal racional, pero tampoco lo hará a ser un animal sociable, o en un ente psíquico, o incluso biológico. Dado que el hombre no es ningún "ente", sino más bien un "existente" con lo cual el ser humano no es por tanto ninguna substancia, susceptible de ser determinada objetivamente (Ferrater Mora, 2004).

El pensador catalán describe lo existencial sin absolutismos. Lo define en todo caso como algo que va más allá de la simple lógica. Aunque para dar su explicación lo hace de forma tautológica, no trata de establecer una caracterización de tipo axiomática. Para ello Ferrater Mora describe varios procesos y logra integrar diversas ideas, en coincidencia con el integracionismo y el uso de los conceptos-límites, con lo cual se establece la presencia de elementos existenciales en su filosofía.

Acercar una filosofía como el "empirismo" con la "dialéctica" constituye en sí una suerte de reto, ya que desde los conceptos establecidos en cada una de esas formas de pensamiento también se observa que hay distancias entre los propios empíricos y aquellos que se identifican con la dialéctica.

Hablar sobre la base de la experiencia, hacer filosofía desde lo que se observa para luego usar la dialéctica para respaldar cualquier visión que se tenga sobre algún aspecto de la vida, pudiese constituir una experiencia existencial, aunque esa experiencia tenga sus rasgos académicos con el uso de métodos científicos. Hacer ciencia con el pensamiento 
racional, la observación empírica, filosofar sobre la muerte que le da sentido a la vida, sin duda deja una marca y efecto considerable en lo que respecta al tema existencial.

No sería atrevido afirmar que el "integracionismo" o "empirismo dialéctico" puede ser catalogado como una especie de dialéctica existencial, o una dialéctica de carácter existencial. Ciertamente el conjunto de su obra es en sí un vasto compendio enciclopédico, que contiene una historia de la filosofía y de la que el mismo José Ferrater Mora forma parte. No es por lo tanto extraño ni ajeno que la filosofía existencial esté presente, como ya se ha demostrado con los análisis de esta investigación, basada en el método bibliográfico y por lo amplio del discurso ferrateriano respecto a los temas y autores existenciales.

Vale destacar que Ferrater Mora en sus escritos deja por sentado la diferenciación que prevalece entre la filosofía de ayer y la de hoy, en la que que privan diversos significados de existencia que a su vez se distinguen entre sí, pero que necesariamente se enclavan en la interpretación de ésta como raíz del existir o en su defecto como fundamento de una ontología. Por ello, Ferrater seguirá mostrando su importancia, la cual alcanza hoy en día un significado común y es el que deriva de concebir la existencia como un modo de "ser" que nunca es "dado" pero que tampoco es "puesto", con lo cual se hace a sí mismo, ya que la existencia forja su propia esencia y crea su propia inteligibilidad e incluso la del mundo en la que se halla sumida (Ferrater Mora, 2004).

Entonces es posible entrever que se cruzan visiones, métodos y sistemas de pensamiento que tienen como fin hacer una filosofía de la existencia. Desde esa filosofía existencial se abordan los temas del ser, tanto desde su lado material como desde su lado metafísico. Rasgos que están impresos de forma expresa en la filosofía y en la más destacada obra de la bibliografía de José Ferrater Mora.

Considerando que el marco metodológico empleado es el método de investigación bibliográfico, son precisamente los argumentos expuestos los que conducen a exponer, que la obra del filósofo a lo largo de los análisis y lecturas pertinentes, dan evidencia de que su filosofía y método o sistema filosófico es sin duda existencial. Los elementos existenciales están presentes cuando hace comparaciones de sistemas opuestos. Se observa que cuando elabora sus conceptos-límites, los temas de orientación existencial son los más resaltantes. La presente investigación deja expuesto que José Ferrater Mora es un pensador que si bien fue un destacado especialista en hacer una historia y fenomenología de la filosofía (sin ser un historiador de la filosofía) y de producir una obra enciclopédica de envergadura, es un 
filósofo que hizo una aportación considerable a la filosofía española y universal, además de haber escrito un impresionante Diccionario de filosofía.

Tanto en su obra filosófica como enciclopédica hay muestras claras de su dedicación a los temas existenciales, y nunca se manifiesta distante a ellos ni asume un papel detractor. De lo que se asume distante el pensador catalán es de las etiquetas, los absolutismos, los fanatismos, las posturas dogmáticas y de considerarse a sí mismo un propulsor de una secta o de haber fundado una corriente de pensamiento. No es importante para él tener seguidores que realcen su figura intelectual y mucho menos que se haga culto a su personalidad por su legado y obra.

Finalmente, es el pensamiento de José Ferrater Mora tan rico como diverso, el que convoca a través de sus elementos existenciales, con su propia lógica y su propia visión de la realidad las que colocan a la filosofía en una encrucijada -evocando a Carlos Nieto Blanco- en la que no está todo dicho ni escrito, todavía faltan voces y páginas en el pensamiento filosófico que están por escribirse, las cuales siguen inscribiéndose en cada línea sobre la historia de las ideas y de los procesos intelectuales de el ser y la existencia. 


\section{BIBLIOGRAFÍA Y RECURSOS ELECTRÓNICOS.}

ABAD, Francisco. (2012). “Semblanza de José Ferrater Mora (1912-1991)”. ISSN: 11308508 RLLCGV, XVII págs. 255-258. Universidad Nacional de Educación a Distancia.

ABELLÁN, José Luis. (1979) “Historia crítica del pensamiento español”. Madrid. Espasa Calpe.

ALER GAY, Trinidad. (1986). "Sobre el libro de José Ferrater Mora, 'Unamuno. Bosquejo de una filosofía'”. Anales del SM (Madrid), no XXI págs. 242-243 103311/R17A. Madrid: Alianza Editorial.

ALONSO-FUEYO, Sabino. (1949). "Existencialismo español. Ortega y Gasset, Unamuno y Xavier Zubiri”. Saitabi Revista de la Facultad de Geografía e Historia.

BONETE PEBALES, Enrique. "La teoría ética de José Ferrater Mora”. Universidad Pontificia de Salamanca, en: summa.upsa.es/high.raw?id=0000000846\&name $=00000001$.original.pdf...pdf Consultado el 17 de enero de 2017

BUNGE, Mario. (2011). “100 Ideas”. Buenos Aires: Penguin Random House.

CAMPOS OCAMPO, Melvin. (2009) "Métodos y técnicas de investigación académica. Fundamentos de investigación bibliográfica”. Pág. 17, Universidad de Costa Rica. Sede de Occidente. Sistema de Educación General. Curso Integrado de Humanidades, en:

http://www.icomoscr.org/m/investigacion/\%5BMETODOS\%5DFolleto_v.1.pdf Consultado el 17 de enero de 2017

CAMUS, Albert. (2006). "El mito de Sísifo". Madrid: Alianza Editorial.

CHANTA, René (2014) "Reflexiones sobre el ser humano en la filosofía de José Ferrater Mora”. TEORÍA Y PRAXIS No. 24, Enero-Mayo.

COMTE-SPONVILLE, André. (2003). “Diccionario filosófico". Traducción: Jordi Terré. Barcelona: Paidós.

COPLESTON, Frederick. (2003). "Logical Positivism and Existentialism. A History of Philosophy". Volume 11. Logical positivism and existentialism. New York: Continuum. 
DALLA MORA, Roberto. (2015a) "Aproximación a la presencia de José Ferrater Mora en España tras la Guerra Civil (1952-1980)". [Actas I Congreso internacional de la Red española de Filosofía] ISBN 978-84-370-9680-3, Vol. XIV 29-35. Universidad Autónoma de Madrid

DALLA MORA, Roberto. (2015b). "La resistencia amable de José Ferrater Mora". TALES. Revista de Filosofía. № 5. Universidad Autónoma de Madrid.

DÍAZ, Carlos. (2002). "Breve historia de la filosofía”. Diecisiete lecciones. Madrid: Encuentro Ediciones.

DÍAZ, Lola. (21 de octubre, 1985). "Ferrater Mora: paseo por el amor, la filosofía y la muerte". Cambio 16, 725, en:

http://www.ferratermora.org/biog_interviews_cambio.html

Consultado el 30 de diciembre de 2016

DRU, Alexander. (1938). “The Journals of Søren Kierkegaard”. Londres - NY - Toronto. Oxford University Press.

ECO, Umberto. (2001). “Cómo se hace una tesis”. Traducción: Lucía Baranda y Alberto Clavería Ibáñez. Barcelona: Editorial Gedisa.

EDITORIAL CRUZ DEL SUR, (1942). Colección Tierra Firme, prólogo. Santiago de Chile.

“EL ASILO CONTRA LA OPRESIÓN. Los refugiados españoles en Chile (1939)". Temas: Demografía y migración. Memoria Chilena, Biblioteca Nacional de Chile (DIBAM), en: http://www.memoriachilena.cl/602/w3-article732.html\#presentacion

Consultado el 30 de mayo de 2016

FERRATER MORA, José. (1942). “España y Europa”, Santiago de Chile: Cruz del Sur.

FERRATER MORA, José. (1944) "Las formas de la vida catalana”, Santiago de Chile: Agrupación Patriótica Catalana.

FERRATER MORA, José. (1944) "Unamuno: Bosquejo de una filosofía”, Buenos Aires: Losada.

FERRATER MORA, José. (1947) "El sentido de la muerte”, Buenos Aires: Sudamericana.

FERRATER MORA, José. (1946) “La ironía, la muerte y la admiración”, México. 
FERRATER MORA, José. (1958). “Eugenio d'Ors (1882-1954)”. Diccionario de filosofía. Buenos Aires [cuarta edición] páginas 1010-1011. Editorial Sudamericana.

FERRATER MORA, José. (1962). "El ser y la muerte: bosquejo de una filosofía integracionista". 1a ed. Madrid. Aguilar, en:

http://www.ferratermora.org/spec_muerte_intro.html

Consultado el 04 de enero de 2017

FERRATER MORA, José. (1969). “La filosofia actual”. Madrid: Alianza Editorial.

FERRATER MORA, José. (1970). “Indagaciones sobre el lenguaje”. Madrid: Alianza Editorial.

FERRATER MORA, José. (1973). “Ortega y Gasset. Etapas de una filosofía”. Barcelona: Seix Barral.

FERRATER MORA, José. (1979). “De la materia a la razón”. Madrid: Alianza Editorial.

FERRATER MORA, José. (2004). "Diccionario de Filosofía”. Nueva edición -3a reimpresión- actualizada por la Cátedra Ferrater Mora, bajo la dirección de JosepMaría Terricabras. Barcelona: Editorial Ariel.

FERRATER MORA, José. (2015). “Diccionario de Filosofia”. 4 vols. Barcelona, Ariel.

FERNÁNDEZ DE LA MORA, Gonzalo. (1962) "El Ser y la Muerte, de José Ferrater Mora”. Ed. Aguilar, Madrid 1962, 294 págs. Reproducido por: ABC diario ilustrado. Año 56, número 17.896 páginas 41-42 Madrid, jueves 25 de julio de 1963 en: http://filosofia.org/hem/dep/abc/9630725.htm

Consultado el 29 de diciembre de 2016

FUNDACIÓN GUSTAVO BUENO SÁNCHEZ (2012). "José Ferrater Mora en su centenario". [Conferencia] Oviedo, 10 de diciembre de 2012. Escuela de Filosofía de Oviedo, en:

https://www.youtube.com/watch?v=AguYDr8cr18

Consultado el 20 de febrero de 2017

GALÁN AMADOR, Manuel. (2011). “La investigación documental”. [Entrada en Blog] Metodología de la investigación. en: http://manuelgalan.blogspot.com/2011/09/la-investgacion-documental_1557.html Consultado: 10 de enero de 2017

GÓMEZ MOLLEDA, María Dolores. (1989). "Actas del Congreso Internacional Cincuentenario de Unamuno”. Ediciones Universidad de Salamanca. 
GRACIA, Jordi. (2012a). “Burguesos imperfectes. L'etica de l'heterodoxia a les lletres catalans del segle XX”. Barcelona: La Magrana.

GRACIA, Jordi. (2012b). "El compromís d'un pensador o la vocació de Ferrater Mora". Via. Valors, Idees, Actituds: Revista del centre d'estudis Jordi Pujol, 49, pp. 52-68.

GRACIA, Jordi. (2013). "Ferrater Mora o la gracia de la razón”. Claves de razón práctica, 227, pp. 158-165.

GRACIA, Jordi. \& RÓDENAS, Dámaso. (2009). "El ensayo español: siglo XX”, Barcelona, Crítica.

GUY, Alain. (1985). “Historia de la filosofía española”. Anthropos Editorial.

HEGEL, Georg Wilhelm Friedrich. (1999). "Fenomenología del espiritu” -6 reimpresión en España-. Madrid: Fondo de Cultura Económica.

HERNÁNDEZ, Laura. (2001) “Ironía y Método en la Filosofía de Wittgenstein”. Signos filosóficos, núm. 6, julio-diciembre. Iztapalapa. Universidad Autónoma Metropolitana, en: http://www.redalyc.org/html/343/34300606/

Consultado el 4 de marzo de 2017.

HORTA, Óscar (2010) "Un reino de este mundo: las aportaciones en ética de Ferrater Mora” Enrahonar 44, 35-49. Fundación Española para la Ciencia y la Tecnología. Rutgers University

JASPERS, Karl. (1932). “Philosophie”. Vol. II: Existenzerhellung. Berlin: Springer.

JOLIVET, Regis, (1953). "Las doctrinas existencialistas desde Kierkegaard a J.P. Sartre”. Madrid: Gredos.

JONAS, Hans. (1993). "La gnosis y el espíritu de la antigüedad tardía. De la mitología a la filosofía mística”. «Presentación: Agustín Andreu (1999): Gnosticismo y mundo moderno. pp 33-34». Valencia. Institució Alfons el Magnànim.

KIERKEGAARD, Sören. (1984). "El concepto de la angustia". Traducción, prólogo y notas por Demetrio G. Rivero. Barcelona: Ediciones Orbis.

LA GUIA. (2012). “Existencia”. [Entrada en Blog], en: http://filosofia.laguia2000.com/diccionario-de-filosofia/existencia Consultado el 10 de enero de 2017 
LÓPEZ ALONSO, Santos. (1968). “José Ferrater Mora”. Enciclopedia de la Cultura Española. Tomo 5. páginas 758-759. Madrid: Editora Nacional.

MARCEL, Gabriel. (1987). “Aproximación al misterio del ser: Posición y aproximaciones concretas al misterio ontológico". Madrid: Encuentro Ediciones.

MARÍAS, Julian. (1998). "Historia de la filosofía”. 32a edición. Biblioteca de la Revista de Occidente. Madrid: Hunab KU. Proyecto Baktun, en:

http://iesdi.org/universidadvirtual/Biblioteca_Virtual/Libros_de_Licenciatura/SEG UNTO_TETRAMESTRE/T0208\%20Filosof\%EDa\%20General/Marias\%20Julian $\% 20-\% 20$ Historia\%20De\%20La\%20Filosofia.PDF

Consultado el 4 de marzo de 2017.

MARICHAL, Juan (1982). “El pensamiento español transterrado (1939-1979)”. Revista de la Universidad de México No. 10. ISSN: 01851330. Tomado de: www.revistadelauniversidad.unam.mx/ojs_rum/files/.../1/.../11424-16822-1-PB

MARICHAL, Juan. (1984) “Teoría e historia del ensayismo hispánico”. Madrid, Alianza.

MÁRQUEZ, Antonio. (1971) "Encuentro en USA con Ferrater Mora”. Cultura. Filosofía española, año XXXIII, $\mathrm{n}^{\circ}$ 10.356, página 14. Madrid diario de la noche, en: http://www.filosofia.org/hem/dep/mad/9710825.htm Consultado el 30 de enero de 2017

MERLEAU-PONTY, Maurice. (1975). “Fenomenología de la percepción”. Traducción de J. Cabanes. Barcelona: Península.

MORALES, José Ricardo. (1991). "José Ferrater Mora y su obra literaria”. Conferencia ofrecida en el Encuentro Homenaje a la memoria de José Ferrater Mora, en los Cursos de Verano 1991 de la Universidad Complutense de Madrid. San Lorenzo del Escorial, julio de 1991.

MONTOTO, Santiago. (2005). "Esquinas y conventos de Sevilla”. -3 edición- Sevilla: Universidad de Sevilla. Secretariado de Publicaciones.

MOUNIER, Emmanuel. (1973). "Introducción a los existencialismos". Madrid: Guadarrama Ediciones.

NIETO BLANCO, Carlos. (1984). "Ferrater Mora y la ontología contemporánea”, en: www.raco.cat/index.php/Enrahonar/article/download/42519/90496 Consultado el 30 de diciembre de 2016 
NIETO BLANCO, Carlos. (1985). "La filosofía en la encrucijada. Perfiles del pensamiento de José Ferrater Mora”, prólogo de Javier Muguerza, Barcelona, Servicio de Publicaciones de la Universidad Autónoma.

NIETO BLANCO, Carlos. "Cultura y política en el pensamiento de José Ferrater Mora" En SÁNCHEZ CUERVO, Antolín \& HERMIDA DE BLAS, Fernando (2010). "Pensamiento exiliado español: el legado filosófico del 39 y su dimensión iberoamericana". ISBN 9788400091989, págs. 126-163. Consejo Superior de Investigaciones Científicas.

NIETO BLANCO, Carlos (2002). "El mundo desde dentro. Una aproximación al discurso ontológico de Ferrater Mora" [Ponencia dentro del Symposium Internacional Cátedra Ferrater Mora, titulado "La filosofía de J. Ferrater Mora", celebrado en la Universitat de Girona los días 21 y el 22 de Noviembre de 2002]. Universidad de Cantabria

NIETO BLANCO, Carlos. (2014) "Narrativa y periodismo en la obra de José Ferrater Mora”. III Congreso Internacional de Literatura y Cultura. Españolas Contemporáneas

NIETO BLANCO, Carlos. (2015). "El escritor y su mundo: Narratividad y filosofía en la obra de Ferrater Mora". [Actas I Congreso internacional de la Red española de Filosofía] ISBN 978-84-370-9680-3, Vol. XIV: 13-28. Universidad de Cantabria.

OLIVER, Joan. [Pere Quart]. (1981). “Notes on a Friendship”. en P. Cohn (ed.), Transparencies. Philosophicals Essays in Honor of J. Ferrater Mora. pp. 1-4. Atlantic Highlands. N.J: Humanities Press.

ORTEGA Y GASSET, José. (1989). "Historia como sistema. Obras completas". VI, Madrid: Alianza / Revista de Occidente.

ORTEGA Y GASSET, José. (2004). “Obras completas”, Vol. I. p. 757. Madrid: Ed. Taurus / Fundación José Ortega y Gasset.

ORTEGA VILlLALOBOS, Julio. (1992). "Entrevista con José Ferrater Mora sobre su estancia en Chile”. pág. 89. Madrid: Boletín de la Institución Libre de Enseñanza.

ORTEGA VILLALOBOS, Julio. (1996). “José Ferrater Mora en Chile: filosofía y exilio”. [Actas de las II Jornadas de Hispanismo Filosófico (1995)]. El Basilisco (Oviedo), nº 21, pág. 86-89, en:

http://www.filosofia.org/rev/bas/bas22134.htm

Consultado 25 de marzo de 2017. 
PAPINEAU, David. (2004). "Filosofía. Guía ilustrada para comprender y usar la filosofía hoy en día”. Traducción Miguel Iribarren Berrade. Barcelona: Blume.

PLA, Josep. (1970) “Entrevista: Visita a Ferrater Mora”. Obra completa. Volumen XVI. Homenots segona sèrie, pp. 127-174. Barcelona: Ediciones Destino, en: http://www.ferratermora.org/biog_interviews_pla.html Consultado el 20 de mayo de 2017.

PLAZAS, Elizabeth. (2011). Investigación Documental I. [Entrada en Blog], en: http://rossettha-investigaciondocumental.blogspot.com/2011/02/investigaciondocumental-i.html Consultado el 10 de enero de 2017

PROYECTO FILOSOFÍA EN ESPAÑOL. (2012). “José Ferrater Mora 1912-1991”, en: http://www.filosofia.org/ave/001/a379.htm Consultado el 20 de mayo de 2017

PRINI, Pietro. (1957). "Las tres edades del Existencialismo”. Monteagudo. Revista de literatura española, hispanoamericana y teoría de la literatura, en: https://digitum.um.es/jspui/bitstream/10201/14841/1/01\%20vol19\%20Las\%20tres \%20edades\%20del\%20existencialismo.pdf Consultado el 11 de febrero de 2017

QUESADA MOLINA, María Paz (1996). "José Ferrater Mora: Del raciovitalismo a la filosofía analítica”. [Tesis Doctoral]. Pamplona: Universidad de Navarra

RUBIO DE CASTARLENAS, Alfredo. (1980) "22 Historias clínicas de realismo existencial”. Edimurtra.

SANTOS LÓPEZ, Alonso. (1968) “José Ferrater Mora”. Enciclopedia de la Cultura Española, tomo 5, páginas 758-759. Madrid. Editora Nacional. en: http://www.filosofia.org/enc/ece/e50758.htm Consultado 05 de febrero de 2017.

SARTRE, Jean-Paul. (2006). "El existencialismo es un humanismo”. Ciudad de México. Universidad Nacional Autónoma de México. 
TEOREMA. (1972). "Entrevista a José Ferrater Mora", en:

http://www.ferratermora.org/biog_interviews_teo.html

Consultado el 20 de mayo de 2017

TERRICABRAS, Josep-Maria. "Estilo y pensamiento en la obra de Ferrater Mora" Cátedra Ferrater Mora de Pensamiento Contemporáneo. Universidad de Girona, en: http://www.alcoberro.info/docs/examples/ferrater/ferrater001.html

Consultado 25 de mayo de 2017.

TERRICABRAS, Josep-Maria \& BARDERA, Damià (2014). "Josep Ferrater Mora (1912-1991)”. Biobibliografia. Revista d'història de la filosofia catalana, Números 7/8, Print ISSN 2014-1572 / Online ISSN 2014-1564 DOI: 10.2436/20.3001.02.98.

P. 113-154, en:

http://revistes.iec.cat/index.php/JOCIH

Consultado 21 de febrero de 2017.

TERRICABRAS, Josep-Maria. (2008) "Mente y cerebro en el pensamiento de Ferrater Mora" [Publicado en versión catalana como: "Ment i cervell en el pensament de Ferrater Mora"] La filosofía de Ferrater Mora, Documenta universitaria, ISBN 97884-96742-39-0, pp. 149-162. Girona.

UNAMUNO, Miguel de. (1983). "Del sentimiento trágico de la vida. La agonía del cristianismo”. Serie Unamuno Filosofía. Madrid. Akal.

VELÁSQUEZ GIRALDO, Carla Isabel. (2015a) "Dos ideas de Ferrater Mora sobre los animales Existencialismo y ciencia". Actas I Congreso internacional de la Red española de Filosofía ISBN 978-84-370-9680-3, Vol. XVIII. 55-59. Universidad Autónoma de Barcelona

VELÁSQUEZ GIRALDO, Carla Isabel. (2015b). "La relación entre filosofía y ciencia en la obra de José Ferrater Mora”. [Tesis Doctoral]. Universidad Autónoma de Barcelona.

VOLPI, Franco. (ed.) (2005). "Enciclopedia de obras de filosofía”. Traducción de Raúl Gabás Pallás. Barcelona: Herder Editorial. 


\section{ANEXOS.}

Anexo 1: Cátedra de Ferrater Mora de pensamiento contemporáneo.

La Cátedra Ferrater Mora de Pensamiento Contemporáneo fue creada el 2 de noviembre de 1989, tal como lo reseña su site oficial www.catedraferratermora.cat/ surge con el objetivo básico de organizar cursos de pensamiento contemporáneo dirigidos por pensadores eminentes con prestigio reconocido a nivel internacional.

Es una cátedra de pensamiento, el equipo que le dirige sostiene que no responde estrictamente a temas de filosofía, pues explica en su sitio web está abierta a la docencia interdisciplinaria de personalidades de ámbitos diversos, tanto de la filosofía como de las ciencias o de las artes, ya sean formales, experimentales, históricas o humanas. Sin embargo, es también una cátedra de pensamiento contemporáneo en un sentido muy estricto, para que los profesores que son invitados expongan las líneas maestras de su propio pensamiento.

Desde su creación y hasta la fecha, la Cátedra tiene periodos habituales de docencia, existen dos fijos que arrancan durante el mes de noviembre y durante el mes de junio. La primera sesión de lecciones fue dirigida por el propio pensador catalán José Ferrater Mora en noviembre de 1989. Actualmente es dirigida por el Prof. Dr. Joan Vergés Gifra, y con el Prof. Dr. Josep-Maria Terricabras como director honorario.

La Cátedra Ferrater Mora destina parte de sus recursos a incrementar sus fondos bibliográficos, los cuales son abiertos a consulta pública. Cuentan así con el Fondo Cátedra Ferrater Mora, el cual está formado principalmente a partir de la obra de todos los pensadores que han dirigido seminarios en la Cátedra desde su creación, las cuales han sido adquiridas con ocasión de sus visitas a la Cátedra y/o en algunos casos dadas por los mismos pensadores.

Asimismo, la Cátedra Ferrater Mora cuenta con un fondo muy completo de la obra de Ludwig Wittgenstein, el fondo que lleva su nombre contiene la obra completa del autor en diferentes ediciones y traducciones a diferentes lenguas, y un buen número de títulos de bibliografía secundaria sobre su obra. Destacando además que cuenta con los Wittgenstein Papers, compilación exhaustiva de todos los escritos de Wittgenstein, publicados o no, en forma de microfilm. 
A finales del curso 2007- 08 nació el Seminario Raimon Panikkar de Pensamiento Intercultural el cual fue acogido por la Cátedra Ferrater Mora y cuenta con su apoyo, pero funciona con plena autonomía, bajo el nombre y la figura de Raimon Panikkar en ocasión de su doctorado honoris causa por la Universidad de Girona.

El seminario, que representa un grupo de estudios dinamizador del Fondo Raimon Panikkar depositado en la Biblioteca del casco antiguo de la Facultad de Letras, pretende ser un espacio de estudio y meditación, a partir del trabajo con los textos de las grandes tradiciones de sabiduría, así como del pensamiento contemporáneo de los diversos ámbitos filosóficos con una mirada intercultural.

Vale hacer mención que en el año 2005 la Cátedra Ferrater Mora inició una colaboración estrecha con el Instituto Nahmànides de Girona para organizar conjuntamente cursos de pensamiento y cultura principalmente judía, aunque no excluyente de otras culturas. Los cursos tienen lugar en la sede del Instituto Nahmánides, en medio de la judería, normalmente durante los primeros cinco meses del año.

Dentro de los cursos que ha llevado a cabo la Cátedra Ferrater Mora destacan:

2017 El hechizo de Tíbet. El realismo mágico del techo del mundo

2014 Generosidad, ternura, sabiduría

2014 Reconocimiento, pactismo y patriotismo

2014 El budismo tántrico y la tradición tibetana

2013 Leer, escribir, hablar

2013 Caridad, empatía, compasión

2013 Introducción al budismo. La doctrina de Buda y los otros budismos

2012 Coraje, audacia y determinación

2012 Amor, amistad y entusiasmo

2011 Integración, justicia y tolerancia

2011 Competencia, decisión y sensatez

2010 Una introducción a la Filosofía de Asia. Los maestros de la no-dualidad asiática: Shankara, el vedanta advaita hindú 
2010 Conocimiento, reflexión y crítica

2010 Sinceridad, autoestima y atrevimiento

2009 Una introducción a la Filosofía de Asia. Los maestros de la no-dualidad asiática

(I): Nagarjuna

2009 Esfuerzo, disciplina e imaginación

2009 Intimidad, espontaneidad y esperanza

2008 Profesionalidad, imagen personal y bienestar

2007 Laicismo, buena educación y religiosidad

2007 Civismo, ecologismo y feminismo

2006 Ética aplicada a la intervención social: análisis de temáticas y situaciones de ética que afectan a usuarios y profesionales

2006 Los proyectos de país en la Cataluña contemporánea: adscripciones ideológicas y liberación nacional

2006 Éticas aplicadas a la intervención social

2006 Los proyectos de país en la Cataluña contemporánea: adscripciones ideológicas y liberación nacional

2006 Igualdad, no violencia y democracia

2005 Ecología Política

2005 Choque de civilizaciones? La filosofía política, ahora

2005 Solidaridad, felicidad y libertad

2004 Ética aplicada a la gestión pública

2004 La sociedad de la duda

2004 Entender la Sociedad del Riesgo

2.003 Ética aplicada a los Servicios Sociales

2002 Ética ambiental

2001 Curso de especialización "Sociedad de la información y ética aplicada"

2001 Cuestiones de ética aplicada: bioética y tecnoética 
Anexo 2: Publicaciones acerca de la vida y obra de José Ferrater Mora.

José Ferrater Mora ha sido objeto de estudio de múltiples investigadores, tal como lo reseña el sitio electrónico Cátedra Ferrater Mora, el cual brinda aportes acerca de su legado intelectual. Se considera oportuno rescatar las distintas investigaciones que con respecto a sus pensamientos se ha hecho a lo largo de su vida e incluso tras su partida, algunas de ellas referencia obligada para la presente investigación acerca de la vida y obra del filósofo catalán.

\section{1}

Julián Marías. "El Diccionario de Filosofía de José Ferrater Mora". Revista de psicología general y aplicada. v. 6, no 20, pp. 707-710.

\section{8}

Javier Muguerza. “Un libro sobre Ortega”. Ínsula, n 149, p. 3.

Hugo Rodríguez Alcalá. “J. Ferrater Mora en Princeton”. Cuadernos americanos, mayo-junio, pp. 132-140.

\section{9}

José Luis L. Aranguren. "En torno a Ferrater Mora y la nueva edición de su Diccionario". Ínsula, no 148, 1959, p. 3.

Joaquim Carreras Artau. "Bibliografía: un diccionario de filosofia". Arbor, v. 43, n" 159.

Julián Marías. "Ferrater y su Diccionario". Ínsula, no 148, p. 3.

Adolfo Muñoz Alonso. "Las grandes corrientes del pensamiento contemporáneo". Panoramas nacionalistas, España, Madrid: Guadarrama, pp. 401-402.

\section{3}

H. Fernández Suárez. “Ser y muerte”. Ínsula, no 171, p. 25

Pedro Laín. "Ferrater Mora, José, El ser y la muerte, bosqueja de filosofía integracionista”. Revista de Occidente, I, pp. 364-367. 


\section{4}

Gonzalo Fernández de la Mora. "Pensamiento español”. 1963 (De Azorín en Zubiri), Madrid: Rialp, pp. 29-33, 72-76 y 222-226.

J. Izquierdo. “La ontología de J. Ferrater Mora”. Índice, n 183, pp. 20-21.

\section{5}

Helio Carpintero. "Los ensayistas contemporáneos”. Ínsula, no 224-225, pp. 11 y 30.

J. Izquierdo, "Pensadores españoles fuera de España”. Cuadernos americanos, Enerofebrero.

\section{6}

Alain Guy. "Filósofos españoles de ayer y de hoy". Buenos Aires: Losada, pp. 246253 y 307.

José Ramón Marra-López. “Entrevista con Ferrater Mora”. Ínsula, 236-237, p. 13.

\section{7}

José Luis Abellán. 'José Ferrater Mora: una 'ontología integracionista' al nivel del sentido común dentro Filosofía española en América”. (1936-1966), Madrid: Guadarrama, pp. 83-89.

Helio Carpintero. "Cinco aventuras españolas: Ayala, Laín, Aranguren, Ferrater, Marías”. Madrid: Revista de Occidente, pp. 150-190.

Helio Carpintero. "Pensamiento español contemporáneo", dentro Guillermo DíazPlaja, Historia general de las literaturas hispánicas. Barcelona: Vergara, v. VI, pp. 629-673.

Alain Guy. "La reflexión critico sur la muerte chez J. Ferrater Mora". Revue Philosophique, $\mathrm{n}^{\circ}$ 2, pp. 297-304.

Alain Guy. "Las tendencias progresistas dans la philosophie espagnole contemporaine”. Bulletin Hispanique, LXIX, pp. 454-464.

Javier Muguerza. "Ante una nueva edición del Diccionario de filosofía de José Ferrater Mora”. Revista de Occidente, no 49, pp. 95-107

Baltasar Porcel. "Ferrater Mora o el análisis viva". Serra d'Or, Enero, pp. 25-33. 


\section{9}

Joaquín Marco. "Sobre las Obras selectas de Ferrater Mora". Dentro de: Ejercicios literarios, Barcelona: Táber, pp. 461-466.

1970

Alfonso López Quintás, “Filosofía española contemporánea”. Madrid: Católica, pp. 175-181.

Josep Pla. "José Ferrater Mora". Dentro de Homenots: 2da serie, Barcelona: Destino, pp. 129-174.

\section{1}

José Luis Abellán. “La cultura en España”. Madrid: Edicusa, pp. 91-95 y 97-110.

1972

Teorema. "Entrevista a José Ferrater Mora". Teorema, nº 7, pp. 97-108.

1973

Josep Lluís Blasco Estellés. "Las palabras y los hombres, de José Ferrater Mora" [reseña]. Teorema, v. 3, nº 4, pp. 599-602.

1974

José Luis Abellán. “Filosofía española en el exilio. Panorama 1974”. Urogallo, no 26, pp. $62-68$

Cirilio Flórez. "Filosofía española del lenguaje". Cuadernos Salmantinos de Filosofía, no 1/1, pp. 235-241.

\section{6}

Mario Bunge. "El ser No tiene sentido y el sentido No tiene ser: notas para una conceptología”. Teorema, VI / 2, 1976, pp. 201-212.

Alfonso García Suárez. "Cambio de marcha en filosofía”. Teorema, VI / 3-4, pp. $533-535$. 
Reine Guy. "La Theorie sentido chez José Ferrater Mora". Dentro de: Equipe de Recherche associée (ERA), Toulouse: Association de Publications de la Université de Toulouse-Le Mirail, pp. 115-128.

1979

Victoria Camps. “La sinrazón de la razón”. El Basilisco, nº 8, pp. 97-100

Jesús Mosterín. “De la materia a la razón”. Teorema, IX / 2, pp. 201-210.

Javier Muguerza. "De la materia a la razón, pasando por un gran diccionario". El País, suplemento "Libros", 11 de noviembre, pp. 1 у 6.

\section{0}

Alfredo Deaño. “Las concepciones de la lógica”. Madrid: Taurus, pp. 220-225.

\section{1}

Walter Cariddi. "La íntegrazionismo de José Ferrater Mora". Dentro de: José Ferrater Mora. Quattro visione della storia universale. Bari: Edizioni Milella, pp. 11-31.

Priscilla Cohn (ed.). Transparencias: Philosophical essays in honor of J. Ferrater Mora. Atlantic Highland: Humanities Press.

Priscilla Cohn. "Tendiendo Puentes: la teoría del sentido y del continuo en Ferrater Mora". Teorema, $\mathrm{n}^{\circ} \mathrm{XI} / 1$, pp. 37-56.

Joaquín González Muela. "El arte literario de José Ferrater Mora”, La Estafeta Literaria, mayo, pp. 58-62.

Esperanza Guisán. "Ética y logos”. Enrahonar. Cuadernos de Filosofía, no 1, pp. 6776.

A. Jiménez. "Ferrater Mora, José, De la materia a la razón", Revista de Filosofía, 2a serie, IV, Enero-junio.

A. Jiménez. "Ferrater Mora, José, Diccionario de filosofía". Revista de Filosofía, $2^{\mathrm{a}}$ serie, IV, Enero-junio.

Elena Ronzón [et al.]. "Entrevista a José Ferrater Mora". El Basilisco, n 12, pp. 5258. 


\section{2}

Cirilio Flórez. "Programas de investigación filosófica en España (Tres Ejemplos de ontología)". Actas del II Seminario de Historia de la Filosofía española. Salamanca: Universidad de Salamanca, I, pp. 121-140

Esperanza Guisán. "Por una libertad solidaria”. El País, suplemento "Los libros". febrero, p. 3 .

Ulises Moulines. "Blanco, negro, gris: contra el extremismo filosófico". Dentro de: Exploraciones metacientíficas. Madrid: Alianza, pp. 31-39.

Luís Suñén. "Mirar la calle, contemplar el mundo" (reseña de Claudia, mi Claudia). El País, suplemento "Libros", 21 de noviembre, p. 6.

\section{3}

Dámaso López García. "El observador observación” (reseña de Claudia, mi Claudia). Libros, 13, pp. 11-12.

\section{4}

Salvador Giner. "José Ferrater Mora: una entrevista". Enrahonar. Cuadernos de Filosofía, $\mathrm{n}^{\mathrm{o}}$ 10, pp. 173-182.

Juan Marichal. "El pensamiento español trasterrado (1939-1979)". Dentro de: Teoría e historia del ensayismo hispánico. Madrid: Alianza, pp. 212-224.

Antonio Mora. "La filosofía catalana en el exilio". Enrahonar. Cuadernos de Filosofía, no 10, pp. 17-30.

Carlos Nieto Blanco. "Ferrater Mora y la ontología contemporánea”. Enrahonar. Cuadernos de Filosofía, no 10, pp. 165-172.

\section{5}

Norbert Bilbeny. "José Ferrater y Mora, cruce de lenguajes". Dentro de: Filosofía contemporánea en Cataluña. Barcelona: Edhasa, pp. 261-275.

Priscilla Cohn. "El pensamiento ético de Ferrater Mora". Anthropos. Revista de información y documentación, ${ }^{\circ}$ 49, pp. 36-42.

Esperanza Guisán. "La aportes de Ferrater Mora en la ética contemporánea". Anthropos. Revista de información y documentación, no 49, pp. 42-45. 
Alain Guy. "El integracionismo de J. Ferrater Mora". Cap. V en Historia de la Filosofía Española, Barcelona: Anthropos.

Antonio Mora. "La obra filosófica de J. Ferrater Mora en su trayectoria". Anthropos. Revista de información y documentación, $\mathrm{n}^{\circ}$ 49, pp. 31-36.

Carlos Nieto Blanco. La filosofía en la encrucijada. Perfiles del pensamiento de José Ferrater Mora. Barcelona: Universidad Autónoma de Barcelona.

Carlos Nieto Blanco. "Penúltima palabra filosófica" [sobre De la materia a la razón]. Anthropos. Revista de información y documentación, nº 49, pp. 57-60.

Robert Saladrigas. "El amor de un filósofo miedo las imágenes". La Vanguardia, 12 de septiembre, p. 30.

1987

Enrique Bonete Perales. "La teoría ética de J. Ferrater Mora". Cuadernos salmantinos de filosofía, v. XIV, pp. 349-371.

Xavier Rubert de Ventós. "Ferrater Mora" [entrevista]. Dentro de: Pensadores catalanes. Barcelona: Ediciones 62, pp. 47-60.

\section{8}

Víctor M. Amela. "Isufrible juego" [reseña del libro El juego de la verdad]. La Vanguardia, 3 de marzo, p. 43.

Ismael Martínez Liébana. "Ferrater Mora, José: Modos de acero filosofía” [reseña]. Diálogo filosófico. $\mathrm{n}^{\circ}$ 10, pp. 126-128.

\section{9}

Norbert Bilbeny. "José Ferrater Mora" [entrevista]. Dentro de: Puntas en la almohada: conversaciones con pensadores catalanes. Barcelona: Destino, pp. 67-81.

Soledad Fernández Gago. "El concepto de racionalidad en la filosofía de José Ferrater Mora". Ágora: Papeles de filosofía, no 8, pp. 131-136.

Antonio Mora. "Gente nuestra: Ferrater Mora". Barcelona: Ediciones de Nuevo Arte Thor.

Javier Muguerza. "J. Ferrater Mora: de la materia en la razón pasando por la ética". Revista Latinoamericana de Filosofía, no 15 (2), pp. 219-238. 


\section{0}

Enrique Bonete Perales. "J. Ferrater Mora: los 'anti' de una teoría ética". Dentro de: Éticas contemporáneas, cap. IV, Madrid: Tecnos.

Asunción Maresma. “José Ferrater Mora”. Catalònia, n 17, pp. 32-36.

Javier Muguerza. "De la materia a la razón, pasando, ay, por el hombre”. Dentro de: Desde la perplejidad: Ensayos sobre la ética, la razón y el dialogo. México: Fondo de Cultura Económica, pp. 527-544.

Isidoro Reguera Pérez. “Tanatología Ferrater”. Azafea: revista de filosofía, no 3, pp. 151-178.

\section{1}

Norbert Bilbeny, “José Ferrater Mora: un diccionario”. El Ciervo, 481, pp. 25-29.

Américo Castro. "Ferrater Mora: una superación del localismo". Boletín de la Institución Libre de Enseñanza, II época, nº 11, pp. 23-24.

Cátedra Ferrater Mora de Pensamiento Contemporáneo. "J. Ferrater Mora. In memoriam" Girona: Estudio General de Girona (UAB).

Salvador Giner. "José María Ferrater: el templo irónico". Boletín de la Institución Libre de Enseñanza, II época, nº 11, 33-36.

José Luis López Aranguren. "Ferrater Mora y el estilo de la filosofía española". Boletín de la Institución Libre de Enseñanza, II época, nº 11, pp. 25-26.

Juan Marichal. "Pensador insobornable". Boletín de la Institución Libre de Enseñanza, II época, nº 11, pp. 27-28.

Antonio Mora. "José Ferrater Mora, un diccionario". El Ciervo, n 481, pp. 26-29.

Javier Muguerza. "La desaparición de un maestro". Boletín de la Institución Libre de Enseñanza, II época, $\mathrm{n}^{\circ} 11,29-32$.

Carlos Nieto Blanco. "El legado filosófico de José Ferrater Mora". Diálogo filosófico, $\mathrm{n}^{\circ} 20$, pp. 251-254.

Julio Ortega Villalobos. “José Ferrater Mora”. Isegoría, no 4, pp. 227-228. 
Julio Ortega Villalobos. "El talante filosófico de José Ferrater Mora". Boletín del Ilustre Colegio Oficial de Doctores y Licenciados en Filosofía y Letras y en Ciencias de Madrid, abril.

Julio Ortega Villalobos. "La desaparición de un filósofo". Boletín del seminario de Filosofía del IB "Severo Ochoa” de Alcobendas. Madrid, febrero.

Julio Ortega Villalobos. "Semblanza de un transterrado (Ferrater Mora)". Paideia, Revista de la Sociedad de Profesores de Filosofía de España, Madrid, Octubre.

Joan Pagès. "Integracionismo y continuismo: método y ontología en la filosofía de José Ferrater Mora". Revista de Cataluña, n 53, pp. 24-38.

Ignacio Sánchez Cámara. "El integracionismo de Ferrater Mora y sume impronta orteguiana". Revista de Occidente, n 120, pp. 127-142.

Josep-Maria Terricabras. "José Ferrater Mora, retrato filosófico" [grabación sonora] Barcelona: Ateneu Barcelonès.

1992

Antonio Mora "Inauguración de la Biblioteca de la Cátedra Ferrater Mora, de Girona”. Boletín de la Institución Libre de Enseñanza, nº 15, pp. 85-86.

Julio Ortega Villalobos. "Entrevista con José Ferrater Mora sobre su estancia en Chile", Boletín de la Institución Libre de Enseñanza, nº 15, pp. 87-88.

\section{3}

Isaías Hernández León. "Cinco etapas evolutivas en el pensamiento filosófico de José Ferrater Mora. Un estudio de análisis". Tesina de la Universidad Nacional Autónoma de México.

Denis Huisman. "El ser y la muerte: bosquejar de filosofía integracionista". Dentro de: Dictionaire des Mille oeuvres clés de la philosophie, París: Éditions Nathan.

José Lasaga. "Correspondencia José Ferrater Mora-Antonio Rodríguez Huéscar". Boletín de la Institución Libre de Enseñanza, II época, nº 16, pp. 7-34.

José Lasaga. "Correspondencia José Ferrater Mora-Antonio Rodríguez Huéscar (2 ${ }^{\mathrm{a}}$ parte)”. Boletín de la Institución Libre de Enseñanza, II época, nº 17, pp. 7-34. 
Josep-Maria Terricabras. "José Ferrater Mora. An integrationist philosopher". Man and World. An International Philosophical Review, nº 26 (2), pp. 209-218.

1994

Salvador Giner y Esperanza Guisán [eds.]. José Ferrater Mora: el hombre y su obra. Santiago de Compostela: Universidad de Santiago de Compostela.

Jesús Mosterín. "Semblanza de José Ferrater Mora”. Dentro de: Juan José Acero [et al.]. Perspectivas actuales de lógica y filosofía de la ciencia, Madrid: Siglo XXI, pp. 495508.

Julio Ortega Villalobos. "Ferrater Mora: El período chileno de su filosofía”. Actas de las I Jornadas de la Asociación de Hispanismo filosófico, Madrid: Trotta.

M. Villegas y José Virgilio Ibarz Serrat. “Aproximación a la psicología en la obra de Ferrater Mora”. Revista de historia de la psicología, v. 15, n 3-4, pp. 205-214.

1995

Juan Marichal. "El universo de Ferrater: sobre José Ferrater Mora: el hombre y su obra, de Salvador Giner y Esperanza Guisán [eds.]", Saber leer, nº 84, p. 12.

\section{6}

Julio Ortega Villalobos. "José Ferrater Mora en Chile: filosofía y exilio". El Basilisco, no 21, pp. 86-89.

\section{7}

Biruté Ciplijauskaité. “'Sacar de ti tu mejor tú': un escorzo de José Ferrater Mora”. Hispania, v. 80, nº 2, pp. 280-282.

Denis Huisman. "El ser y la muerte: bosquejar de filosofía integracionista". Dentro de: Diccionario de las mil obras clave del pensamiento, traducción de Carmen García Trevijano, Madrid: Tecnos, pp. 688-689.

1998

Julio Ortega Villalobos. "El exilio cultural y filosófico español en Chile. Propuestas de investigación para un drama ejemplar". Estudios de literatura y pensamiento hispánico de la Sociedad Menéndez Pelayo de Santander, v. 9, Estudios sobre historia del pensamiento español. Actas de las III Jornadas de Hispanismo Filosófico. pp. 295-302. 
Julio Ortega Villalobos. "José Ferrater Mora en Chile: filosofía y exilio". Boletín de la Institución Libre de Enseñanza, II época, nº 31, pp. 39-50.

1999

Joaquim Romaguera Ramió. "José Ferrater y Mora: escritor cinematográfico: cineasta". Revista de Cataluña, nº 145, pp. 53-73.

Conrad Vilanou Torrano. "José Ferrater Mora y la pedagogía: recuperación de un texto olvidado". Educación e historia: Revista de historia de la educación, $\mathrm{n}^{\mathrm{o}}$ 4, pp. 134141.

2000

Antonio Mora. "Ferrater Mora, bajo el imperio de la ley". Hacia un nuevo inventario de la ciencia española. Actas de las IV Jornadas de Hispanismo Filosófico, Santander: Asociación de Hispanismo filosófico / Sociedad Menéndez Pelayo, pp. 391-412.

Julio Ortega Villalobos. "La idea de España y Cataluña en Ferrater Mora". Dentro de: Hacia un nuevo inventario de la ciencia española. Actas de las IV Jornadas de Hispanismo Filosófico, Santander: Asociación de Hispanismo filosófico / Sociedad Menéndez Pelayo, pp. 379-390.

Julio Ortega Villalobos. "Filosofía y Literatura: los mundos posibles en Ferrater Mora”. Instituto Fe y Secularidad. Memoria académica 1999-2000, Madrid.

José Ricardo Morales. "El arte de enterarse (El destierro en el pensamiento de José Ferrater Mora)". Dentro de: Ensayos en suma. Del escritor, el intelectual y sus mundos, Madrid: Biblioteca Nueva, pp. 195-218.

2001

Jesús Mosterín. "José Ferrater Mora”. Dentro de: Filosofía del siglo XX en Cataluña: mirada retrospectiva, IV Ciclo Aranguren, col. Aula de Ciencia y Cultura, no 11, Sabadell: Fundación Caixa de Sabadell, pp. 199-208.

Julio Ortega Villalobos. "El exilio filosófico español en Venezuela, Argentina y Chile”. El exilio cultural de la guerra civil (1936-1939), Salamanca: Ediciones Universidad de Salamanca, pp. 139-150. 
Eulalia Collelldemont Pujadas y Conrad Vilanou Torrano. "Ferrater Mora y la tradición pedagógica republicana”. Boletín de la Institución Libre de Enseñanza, nº 47, pp. 7-22.

Antonio Mora. "Las escrituras de José Ferrater Mora". El Ateneo: revista científica, literaria y artística, $\mathrm{n}^{\mathrm{o}} 11, \mathrm{pp} .43-52$.

\section{3}

Amauri Francisco Gutiérrez Coto. "La filosofía española contemporánea y el grupo origenista de poetas creyentes: una Colaboración de José Ferrater Mora”. Vitral, nº 55.

Josep-Maria Terricabras. "José Ferrater Mora, filósofo". El Espejo, n 13, 139-148.

Josep-Maria Terricabras. "El legado de Ferrater Mora". El Adelanto, n 276, pp. 5758.

2004

Lázaro Bria [et al.]. "Diccionario de filosofía". En Los libros de los filósofos: diccionario-resumen de 850 obras de filosofía y antología de citas, Barcelona: Ariel, pp.183-184.

\section{5}

Carlos Nieto Blanco. "El mundo desde Dentro: una aproximación al discurso ontológico de Ferrater Mora”. Revista de Hispanismo Filosófico, n 10, pp. 59-72.

Oriol Ponsatí Murlà. "Las formas de la vida catalana. Una visión desde el exilio". El Adelanto, no 305, pp. 24-28.

Joaquim Romaguera Ramió. "Diccionario del cine en Cataluña". Barcelona: Enciclopedia catalana, pp. 257-258.

2006

Eduardo Bello. "Three Spanish Philosophers: Unamuno, Ortega and Ferrater

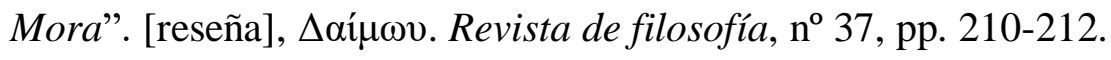

Marta Torregrosa. "Peirce en el Diccionario de filosofía de José Ferrater Mora". Revista Anthropos: Huellas del conocimiento, nº 212, pp. 183-185. 
Josep-Maria Terricabras [coord.]. La filosofía de Ferrater Mora. Girona: Documenta Universitaria.

2008

Óscar Huerta. "La filosofía moral de J. Ferrater Mora". Girona: Documenta Universitaria.

\section{9}

Juan Romay Coca y Jesús A. Valero Matas. "El integracionismo como solución a las guerras de las ciencias”. Intersticios, Revista Sociológica de Pensamiento Crítico, v. $3, \mathrm{n}^{\circ}$ 2, pp. 279-283.

Josep-Maria Terricabras. "Las formas de la vida catalana (1944 a 1960). Identidades". Dentro de: Diez testigos del siglo XX, diez lecciones para el siglo XXI, Barcelona: Instituto de Estudios Catalanes, pp. 149-165 (con una contraponencia de Gabriel Amengual, pp. 167-174).

Josep-Maria Terricabras. "El exilio español en Estados Unidos”. Dentro de: Manuel Garrido, Nelson R. Orringer, Luis M. Valdés y Margarita M. Valdés [coord.], El legado filosófico español e hispanoamericano del siglo XX, Madrid: Cátedra, pp. 617-629.

Josep-Maria Terricabras. "El segundo cenit de Ferrater Mora". Dentro de: Manuel Garrido, Nelson R. Orringer, Luis M. Valdés y Margarita M. Valdés [coord.], El legado filosófico español e hispanoamericano del siglo XX, Madrid: Cátedra, pp. 751-760.

Jordi Gracia y Domingo Rodenas. Ensayo español: siglo XX. Barcelona, Crítica, 2009. pp. 574-593)

2010

Priscilla Cohn. "Ferrater Mora: A Philosopher as novelista". Enrahonar, n 44, pp. $11-21$.

Óscar Huerta. "Un reino de este mundo: las aportaciones en ética de Ferrater Mora". Enrahonar, n 44, pp. 35-49.

Andrew Linzey. "“Enemies of human beings': José Ferrater Mora on blood fiestas”. Enrahonar, $\mathrm{n}^{\circ} 44$, pp. 23-34. 
Carlos Nieto Blanco. "Idioma y filosofía en el pensamiento de José Ferrater Mora". Dentro de: José Luis Mora García [et al.], La filosofía y las lenguas de la península ibérica. Actas de las VIII y IX jornadas internacionales de hispanismo filosófico, Madrid: Fundación Ignacio Larramendi: Asociación de Hispanismo Filosófico: Real Sociedad Menéndez Pelayo: Sociedad Catalana de Filosofía, 2010, pp. 295-322.

Carlos Nieto Blanco. "Cultura y política en el pensamiento de José Ferrater Mora". Dentro de: Antolín Sánchez Cuervo y Fernando Hermida de Blas [coord.]. Pensamiento exiliado español. El legado filosófico del 39 y sume Dimensión iberoamericana, Madrid: Biblioteca Nueva / CSIC, pp. 126-163.

Xavier Serra Labrado. "Dos libros de José Ferrater Mora". Dentro de: Historia social de la filosofía catalana. La lógica (1900-1980), Catarroja: Asuntos, pp. 131-170.

Marta Torregrosa y Jaime Nubiola. "De nuevo, el pragmatismo: Ferrater Mora y Eugenio d'Ors". Dentro de Josep-Maria Terricabras [ed.]. El pensamiento de Eugenio d'Ors, Girona: Documenta Universitaria.

\section{2}

Francisco Abad Nebot. "Semblanza de José Ferrater Mora (1912-1991)". Revista de lenguas y literaturas catalana, gallega y vasca, $\mathrm{n}^{\circ} 17$, pp. 255-258.

Damià Bardera. "La obra narrativa de José Ferrater Mora: un análisis del relato 'Voltaire en Nueva York"'. Trabajo de máster de la Universidad de Girona, 2011/2012.

Jordi Gracia. "El compromiso de un pensador o la vocación de Ferrater Mora". Via. Valores, Ideas, Actitudes: revista del centro de estudios Jordi Pujol, n 19, pp. 52-68.

Frederic Ribas. "Narciso Feliu de la Peña y José Ferrater Mora. Una lección de civilidad y de eficacia”. Revista de Cataluña, no 278, pp. 85-90.

"Suplemento especial por el centenario del nacimiento de José Ferrater Mora". ARA, 23 de abril.

Josep M. Puigjaner. "Los catalanes dibujados por Ferrater Mora". Boletín del Centro de Estudios Jordi Pujol, $\mathrm{n}^{\circ} 317,22$ de noviembre. 
Pompeu Casanovas. "José Ferrater Mora y la historia intelectual: método, ontología y ontologías". Anuario de la Sociedad Catalana de Filosofía, filial del Instituto de Estudios Catalanes, $\mathrm{n}^{\mathrm{o}}$ XXIV, pp. 63-111.

Damià Bardera. "Los anuncios de Estrella Damm: las antiforma de la vida catalana". Dentro de: Damià Bardera y Eudald Espluga, Mediterròniament. La catalanidad emocional [libro electrónico], Biblioteca de la Nube, 6, pp. 7-35.

Josep Borrell. "Del silicio a la razón”. Girona: Documenta Universitaria.

Roberto Dalla Mora. "José Ferrater Mora (1912-91). En el centenario del nacimiento". Revista de Hispanismo Filosófico, n 18, pp. 358-363.

Jordi Gracia. "Ferrater Mora o la gracia de la razón". Claves de razón práctica, $\mathrm{n}^{\circ}$ 227, pp. 158-165.

Clara Alicia Jalifa de Bertranou. "Francisco Romero y sus cartas con intelectuales españoles exiliados. José Ferrater Mora”. Revista de Hispanismo Filosófico, no 18, pp. 89114.

\section{4}

Roberto Dalla Mora. "La estética de José Ferrater Mora, pensador y artista mediterráneo". Dentro de: Filosofías del Sur. Actas de las XI Jornadas de Hispanismo Filosófico [libro electrónico], Madrid: Asociación de Hispanismo Filosófico y Fundación Larramendi [en prensa].

Roberto Dalla Mora. "La breve y sugerente mirada de José Ferrater Mora sobre El Quijote". Dentro de: La recepción de "El Quijote" en el Pensamiento Español del Siglo $X X$, México: Fondo de Cultura Económica [en prensa].

Pompeu Casanovas. "Tres tesis sobre la historiografía y la ontología de Ferrater Mora". Revista de Historia de la Filosofía Catalana, no 7-8, pp. 11-30.

Jordi Sales y Coderch. “A propósito del «integracionismo» de José Ferrater Mora: la posibilidad de las oscilaciones". Revista de Historia de la Filosofía Catalana, n ${ }^{\mathrm{o}} 7-8$, pp. $31-41$. 
Josep-Maria Terricabras. "Ferrater Mora, ideas políticas". Revista de Historia de la Filosofía Catalana, $\mathrm{n}^{\circ}$ 7-8, pp. 43-49.

Xavier Serra [memorialística]. "Tres cartas fundamentales (e inéditas) de José Ferrater Mora el sociólogo Salvador Giner". Revista de Historia de la Filosofía Catalana, n $7-8$, pp. 109-115.

Joan Cuscó. "José Ferrater Mora, Las formas de la vida catalana". Ediciones 62, Barcelona, 2012. Revista de Historia de la Filosofía Catalana, no 7-8, pp. 159-162.

Begoña Román. "Oscar Huerta, La filosofía moral de José Ferrater Mora". [Documenta Universitaria, Girona, 2008]. Revista de Historia de la Filosofía Catalana, ${ }^{\circ}$ 7-8, pp. 163-166.

José Monserrat Molas. “José Ferrater Mora, Three Spanish Philosophers. Unamuno, Ortega and Ferrater Mora". [Edición e introducción de J-M. Terricabras, State University of New York Press, (SUNY series in Latin American and Iberian thought and culture), Albany, 2003] Revista de Historia de la Filosofía Catalana, no 7 -8, pp. 163-170.

Josep-Maria Terricabras y Damià Bardera. "Bibliografía. Josep Ferrater Mora (19121991)”. Revista de Historia de la Filosofía Catalana, no 7-8, pp. 117-158.

Damià Bardera. "Análisis de la obra narrativa de Ferrater Mora desde su filosofía". [Tesis doctoral] 6 de marzo, Universidad de Girona.

\section{5}

Carla Isabel Velásquez. "La relación entre filosofía y ciencia en la obra de José Ferrater Mora". [Tesis doctoral] 30 de noviembre, Universidad Autónoma de Barcelona.

Aunque la reseña de la página web Cátedra Ferrater Mora llega sólo hasta el año 2015, es seguro que el pensamiento del escritor catalán persevera inspirando investigaciones, para muestra un botón, cuyo objetivo es la aproximación a la posibilidad certera de conectar la filosofía de Ferrater Mora a la corriente existencial. 
Anexo 3: Reconocimientos, premios y condecoraciones otorgadas a José Ferrater Mora

José Ferrater Mora tanto en vida como de manera póstuma ha sido merecedor de considerables reconocimientos, algunos de ellos son mencionados a continuación:

Entre ellos se encuentran como los más relevantes que en el año 1984 fue galardonado con la Creu de San Jordi de la Generalidad de Cataluña.

En el año 1985 se le confiere el Premio Príncipe de Asturias de Comunicación y Humanidades en reconocimiento a su esfuerzo integrador de los mundos de la comunicación y las humanidades, y, de esclarecimiento y difusión de las ideas filosóficas.

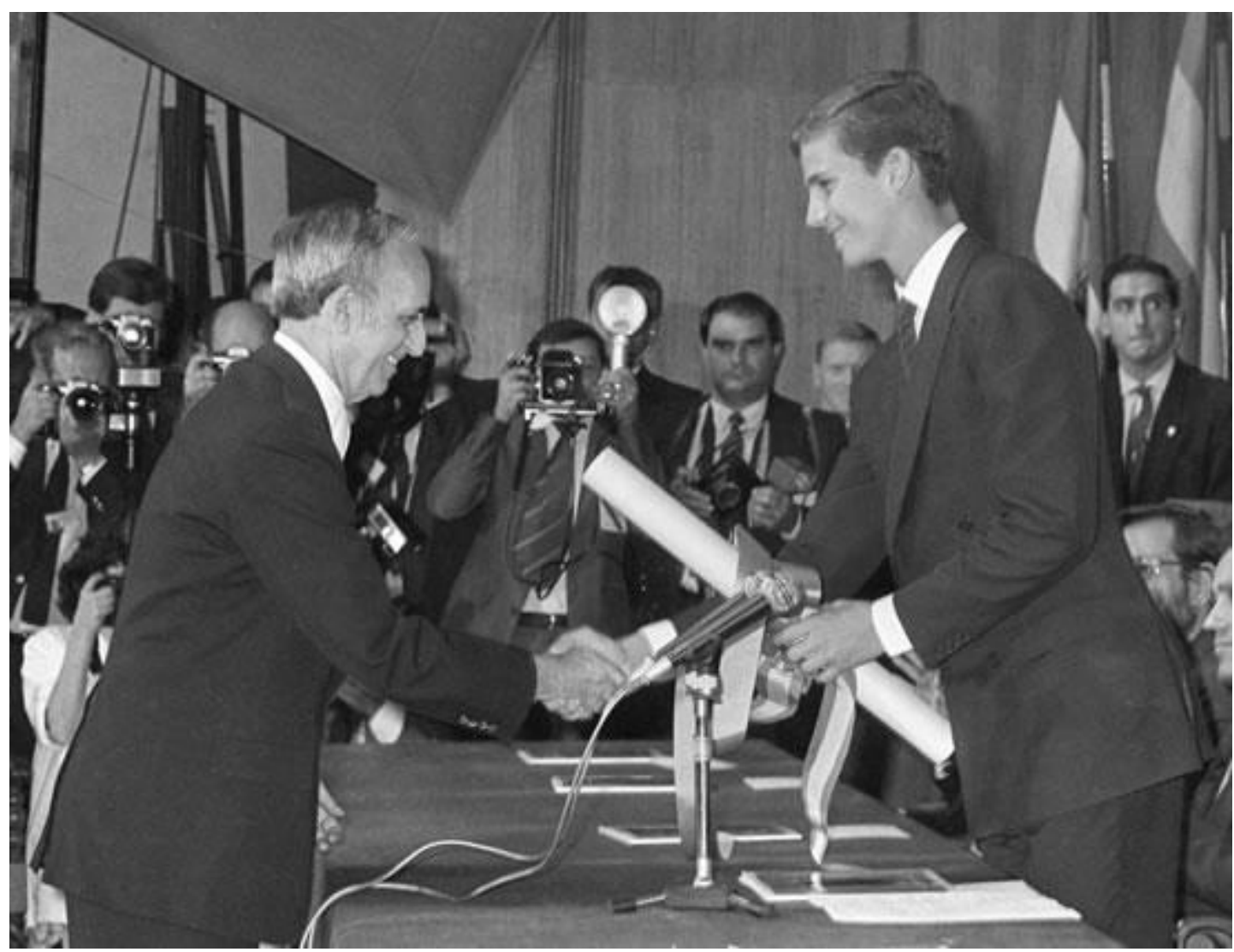

Ilustración 18: Entrega a José Ferrater Mora del premio Príncipe de Asturias en 1985 por su gran aporte a las ciencias humanísticas. (Fuente: Sitio electrónico elbibliote.com). Tomado de: http://elbibliote.com/resources/Temas/html/1717.php).

Además de miembro numerus clausus del Instituto Nacional de Filosofía y de varias sociedades académicas, perteneció a la Academia Norteamericana de Lengua Española.

También recibió la Gran Cruz de Alfonso X el Sabio, la condecoración de Isabel la Católica y la de la de Universidad Internacional de Santander. 
Pero la lista es extensa, como se puede observar al ser detallada:

\section{Doctorados Honoris Causa.}

Fue merecedor de doctorados Honoris Causa por parte de las siguientes academias:

Universidad Autónoma de Barcelona. 1979.
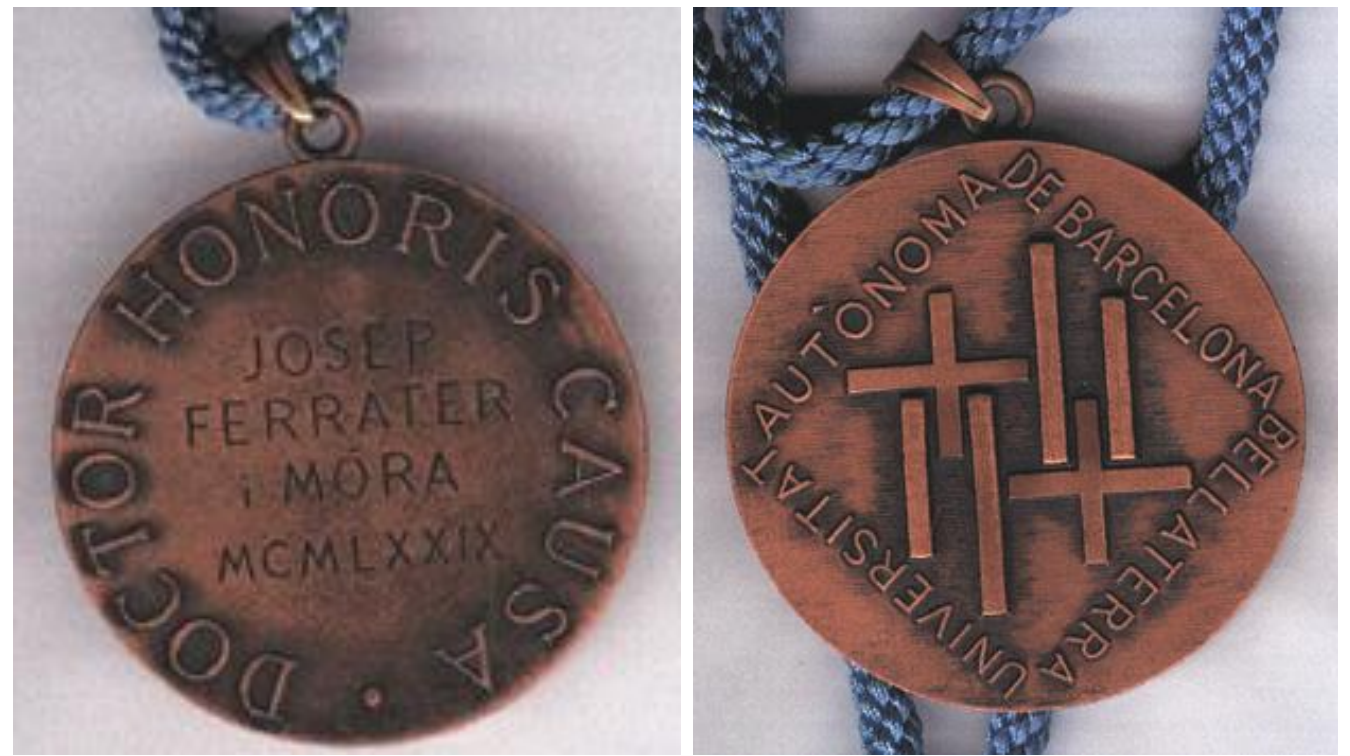

Ilustración 19: Medalla de distinción Doctor Honoris Causa otorgada a José Ferrater Mora por la Universidad Autónoma de Barcelona 1979. (Fuente: Pictures of some of the Awards - sitio electrónico oficial de José Ferrater Mora).

Tomado de: http://www.ferratermora.org/biog_accolades_awardspics.html).

Universidad de Uruguay, Montevideo, Uruguay. 1983.

Universidad de Colombia, Bogotá, Colombia. 1983.

Universidad de Tucumán, Argentina. 1983.

Universidad de Salta, Argentina. 1986.

Universidad Nacional de Educación a Distancia, Madrid, España. 1986,

Universidad Central de Barcelona, 1988

Universidad de Cuyo, Mendoza, Argentina. 1988.

Universidad Central de Barcelona. Barcelona, España. 1988.

\section{Distinciones y condecoraciones.}

Fue honrado con múltiples condecoraciones, entre estas: 
Christian R. y Mary F. Lindback Fundación para la enseñanza distinguida en 1976.

Mérito Cultural, Gobierno Español en 1981.

La Cruz de Isabel La Católica en 1982.

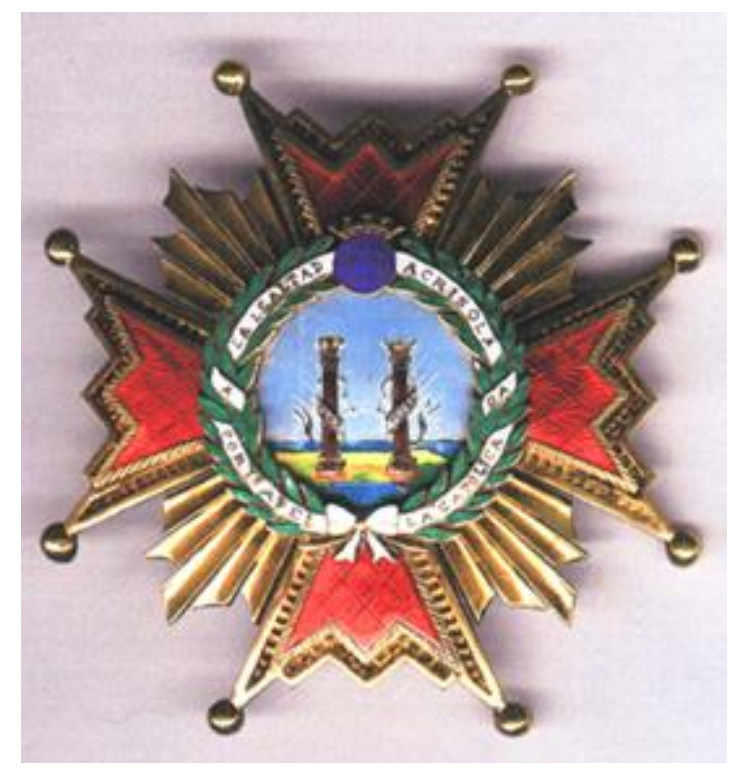

Ilustración 20: Cruz de Isabel La Católica otorgada a José Ferrater Mora en 1982. (Fuente: Pictures of some of the Awards - sitio electrónico oficial Ferrater Mora).

Tomado de: http://www.ferratermora.org/biog_accolades_awardspics.html).

Medalla de la Universidad Internacional Menéndez y Pelayo, Santander, España; en el año 1982.

La Gran Cruz de Alfonso el Sabio, en el año 1984.

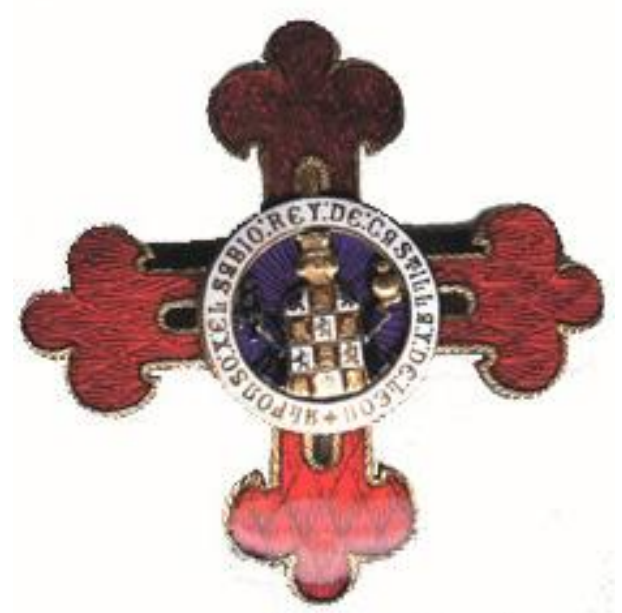

Ilustración 21: Gran Cruz de Alfonso el Sabio otorgada a José Ferrater Mora en 1984.

(Fuente: Pictures of some of the Awards - sitio electrónico oficial Ferrater Mora).

Tomado de: http://www.ferratermora.org/biog_accolades_awardspics.html).

Cruz de Sant Jordi, Generalitat de Catalunya, en el año 1984. 
Premio Príncipe de Asturias, en el año 1985.

Reconocimiento Especial ALDEEU, en el año 1987.

Ferrater Mora Cátedra de Pensamiento Contemporáneo, Universidad de Girona en el año 1989.

Placa de Josep Ferrater Mora, Girona, España; en el año 1993.

Calle Josep Ferrater Mora, Barcelona, España; en el año 1996.

Condecoración de la Universidad de Santiago de Compostela, Galicia, España. 1991 (reconocimiento póstumo).

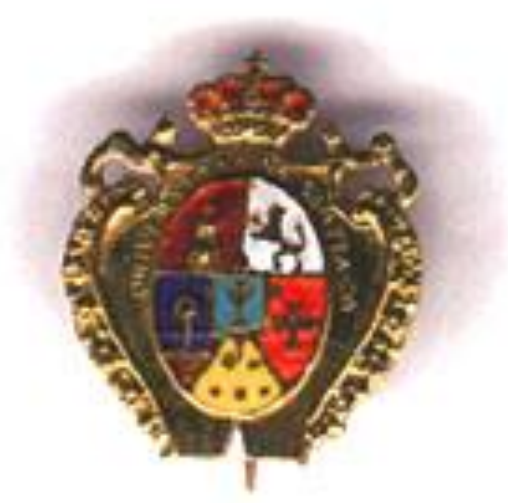

Ilustración 22: Reconocimiento póstumo a José Ferrater Mora por la Universidad Santiago de Compostela 1991.

(Fuente: Pictures of some of the Awards - sitio electrónico oficial Ferrater Mora). Tomado de: http://www.ferratermora.org/biog_accolades_awardspics.html).

\section{Miembro honorario.}

Instituto Internacional de Filosofía.

Sociedad Hispana de América, en el año 1965.

Academia Norteamericana de la Lengua Española, en el año 1982.

Real Academia Española, en el año 1983.

Fundación Miguel Lillo, Argentina; en el año 1983.

Academia de Chile, en el año 1987. 


\section{Invitado especial.}

XIII Congreso Internacional de Filosofía, México; en el año 1963.

Presidente del Simposio Internacional de Lógica y Filosofía de la Ciencia, Valencia; en el año 1971.

Congreso Nacional de Filosofía, Morelia, México; en el año 1974.

Congreso Nacional de Filosofía, Guanajuato, México; en el año 1981.

Gobierno de Argentina; durante los años 1985, 1986 y 1988.

\section{Premios para libros individuales.}

"Concepció Rabell," a Las formas de la vida catalana, Santiago, Chile; en el año 1943.

Finalista del Premio Nadal, con El juego de la verdad; en el año 1987.

\section{Publicaciones y Simposios.}

Transparencias: Ensayos filosóficos en honor de J. Ferrater Mora, P. Cohn (ed); en el año 1981.

José Ferrater Mora: El hombre y su obra, S. Giner, E. Guisan (eds); en el año 1994.

Revista Anthropos \# 49; año 1985.

Simposio sobre la Filosofía de José Ferrater Mora, Bryn Mawr College; en el año 1981.

Homenaje a un humanista, Universidad de Syracuse; en el año 1983.

Memorial, Madrid, España; en el año 1991.

Homenaje a Ferrater Mora, Universidad de Girona; en el año 1991.

Memorial, Bryn Mawr College; en el año 1992.

Josep Ferrater Mora, "De Barcelona a Bryn Mawr", Universidad de Girona; en el año 


\section{Becas o Fellowships.}

Guggenheim Fellowship, durante los años 1947 hasta 1948 y 1948 hasta 1949.

Estudiante senior del American Council of Learned Societies, entre los años $1960 \mathrm{y}$ 1961.

Miembro de la Fundación March.

\section{Profesor visitante.}

Universidad de Princeton, durante los años 1957 hasta 1958.

Universidad John Hopkins, durante los años 1962 hasta 1963.

Universidad del Templo, durante los años 1967 hasta 1968.

Primer titular de la Cátedra Juan Carlos, Universidad de Nueva York; en el año 1987.

Universidad Autónoma de Madrid, España.

Universidad Autónoma de Barcelona, España.

Universidad de Palma Mallorca, Mallorca.

\section{Premios a su desarrollo fílmico.}

Todos los días (año 1973).

Primer Premio, "Películas en una cadena de zapatos".

Una de las mejores películas "subterráneas" por voto de audiencia, Filadelfia.

Traje de noche de (año 1974).

Mención de Honor: Sociedad Fotográfica de América, División de Películas.

Piel de la Tierra (año 1975).

Mención de Honor: Sociedad Fotográfica de América, División de Películas. Venecia 23 (año 1977). 
Certificado de Apreciación: Metropolitan Picture Club.

Lux Perpetua (año 1985).

Premio Cinematografía.

Medalla de plata.

Mejor Película de Viaje.

Sociedad Fotográfica de América, División de Películas.

Reconocimiento especial (1985).

Expositor de una estrella (100 puntos).

Sociedad Fotográfica de América, División de Películas. 
Anexo 4: Materiales hemerográficos acerca de José Ferrater Mora.

LA VIDUA DEL. DESAPAREGUT FILÓSOF TINDRA UNA PARTICPACIO ACTIVA EN LES CONFERENCIES PROGRAMADES

\section{Un simposi sobre Ferrater Mora porta a la UdG experts de tot el món}

Les jornades organitzades per la Càtedra Ferrater Mora tindran lloc els propers dies 21 i 22

\section{\begin{tabular}{|l|l|l|l|l}
\hline DdeG \\
\hline
\end{tabular}}

Gilòsofs de diferents universitats d'Europa i Amèrica participaran durant els dies 21 i 22 de novembre a Girona en un simposi per donar a coneixer el pensament i l'obra de Josep Ferrater Mora, que el dia 30 d'octubre d'aquest any hagués complert 90 anys, segons que va explicar ahir en roda de premsa el professor de la EdG i director de la catedra Ferrater i Mora d'aquesta mateixa universitat, Josep Maria Terricabras.

La vidua de Ferrater Mora, Priscilla Cohn Ferrater Mora, està previst que assisteixi a la inauguració del simposi juntament amb Terricabras i el rector de la Universitat de Girona, Joan Batlle. Altres convidats a aquestes sessions són el filosof Carlos Ulises Moulines, de la Universitat de Munic, José Luis Abellán, de la Universitat Complutense de Madrid; Julio Ortega Vilallobos, de Xile i Gary Calore, de la Penn State University, entre altres. El simposi es completarà amb la projecció de quatre curmetratges rodats per Ferrater i Mora entre el 1970 i el 1980. La jornada del dia 21 estara dedicada a «Ferrater i Mora i la història de la filosofias, i la segona, el dia 22, a "Ontologia, teoria del coneixement, èticas. La clausura d'aquesta segona jornada i del simposi general anirà a carrec de la vídua de Ferrater i Mora, que pronunciarà la conferència uL' tica de Josep Ferrater i Mora i els drets dels animals". Una conferència que lliga perfectament amb el professor convidat de las Càtedra, que serà, l'any 2003, Peter Singer.

Els drets dels animals

La identitat del proper professor convidat també es va fer pública durant el mati d'ahir, i en el decurs

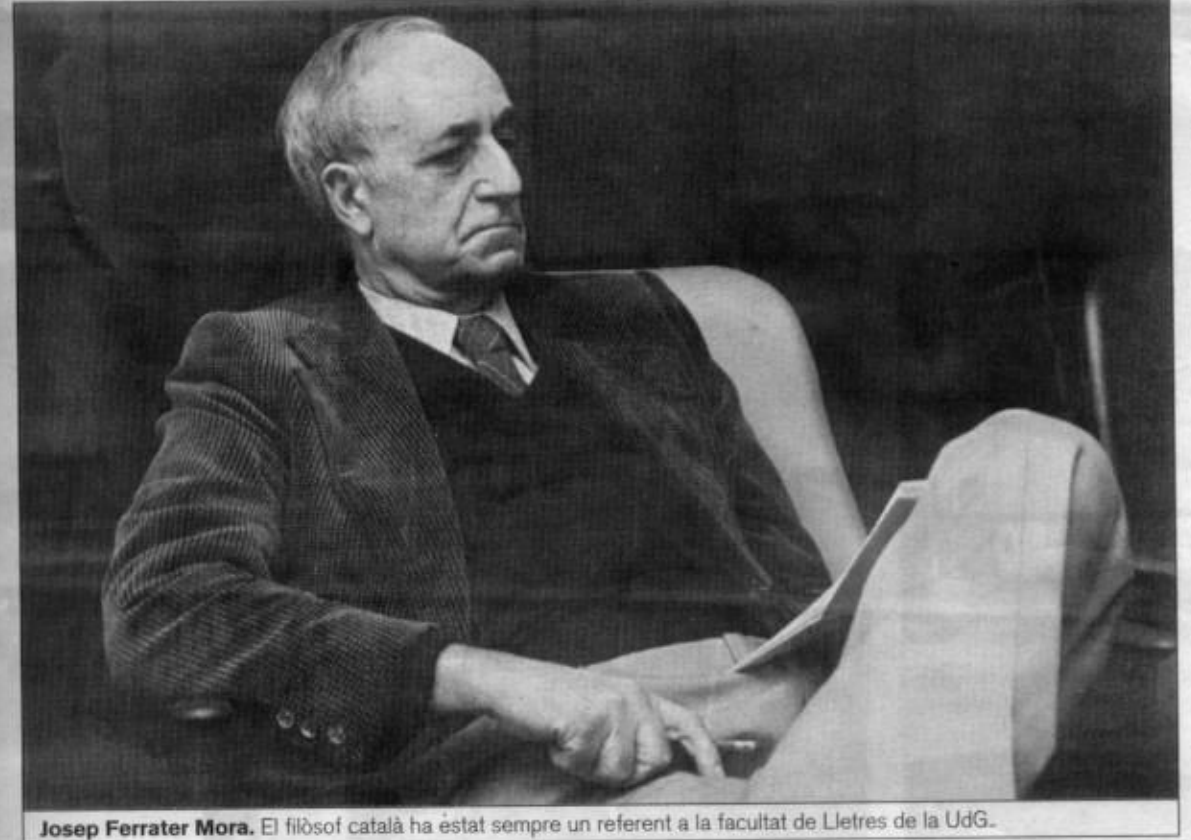

UN ALTRE SIMPOSI INTERESSANT

\section{Després arriba Wittgenstein}

aquest novembre serà ric en va reprendre el seu interès pe simposis a la Càtedra Ferrater i la filosofia. El simposi s'ocupar Mora. Segons es va anunciar precisament de dos dels camps també ahir, els dies 28 i 29 tindrà temàtics que més van interessar lloc el simposi internacional so- el filosof: la filosofia de la mabre Ludwig Wittgenstein, un al- temàtica i la filosofia de la psitre dels filosofs de referència de cologia. Està previst que partilesmentada càtedra de la UdG. cipin en les dues jornades de De fet, ja l'any 1989, amb mo- simposi profesors provinents de tiu del centenari del naixement Queen's College d'Oxford, i de organitzar un simposi sobre el ford, California i Pittsburgh, enseu pensament. El que organit- tre altres.

za la Catedra Ferrater i Mora Wittgenstein es va nacionaés per celebrar quel'any 1927 -és litzar britànic i va viure quasi a dir, fa 75 anys-, Wittgenstein del filosof austriac, la UdG va les universitats de Chicago, Ox- del mateix acte. Peter Singer, nascut a Australia l'any 1946, serà el digne successor d'altres destacats professors que han passat per la Catedra Ferrater Mora de la UdG: Miquel Batllori, Noam Chomsky, Eric J. Hobsbawm, Leonardo Boff, Alain Touraine, Theo Angelopoulos, Luigi Luca Cavalli-Sforza i Ed. gar Morin en són alguns exemples. Peteŕ Singer és catedràtic de Bioètica a la Universitat de Princenton iés autor, entre altres obres, d'Animal Liberation, publicat l'any 1975 , i de Practical Ethics. Singer $s$ ha destacat com un dels principals liders del moviment pels drets dels animals, que creu que s'han d'equiparar als dels humans. Seyla Benhabib serà, l'any 2005, la primera dona professora de la Càtedra Ferrater Mora.

Ilustración 23: Reseña periodística Diario de Girona Miércoles, 13 de noviembre de 2002. Simposio acerca de José Ferrater Mora (Fuente: "Un simposi sobre Ferrater Mora porta a la UdG experts de tot el món" [Traducción: Un simposio sobre Ferrater Mora lleva a la UdG expertos de todo el mundo] en Diario de Girona. Tomado de: http://www3.udg.edu/gabinetr/recull2002/200211/20021113/DdG13.2.jpg). 


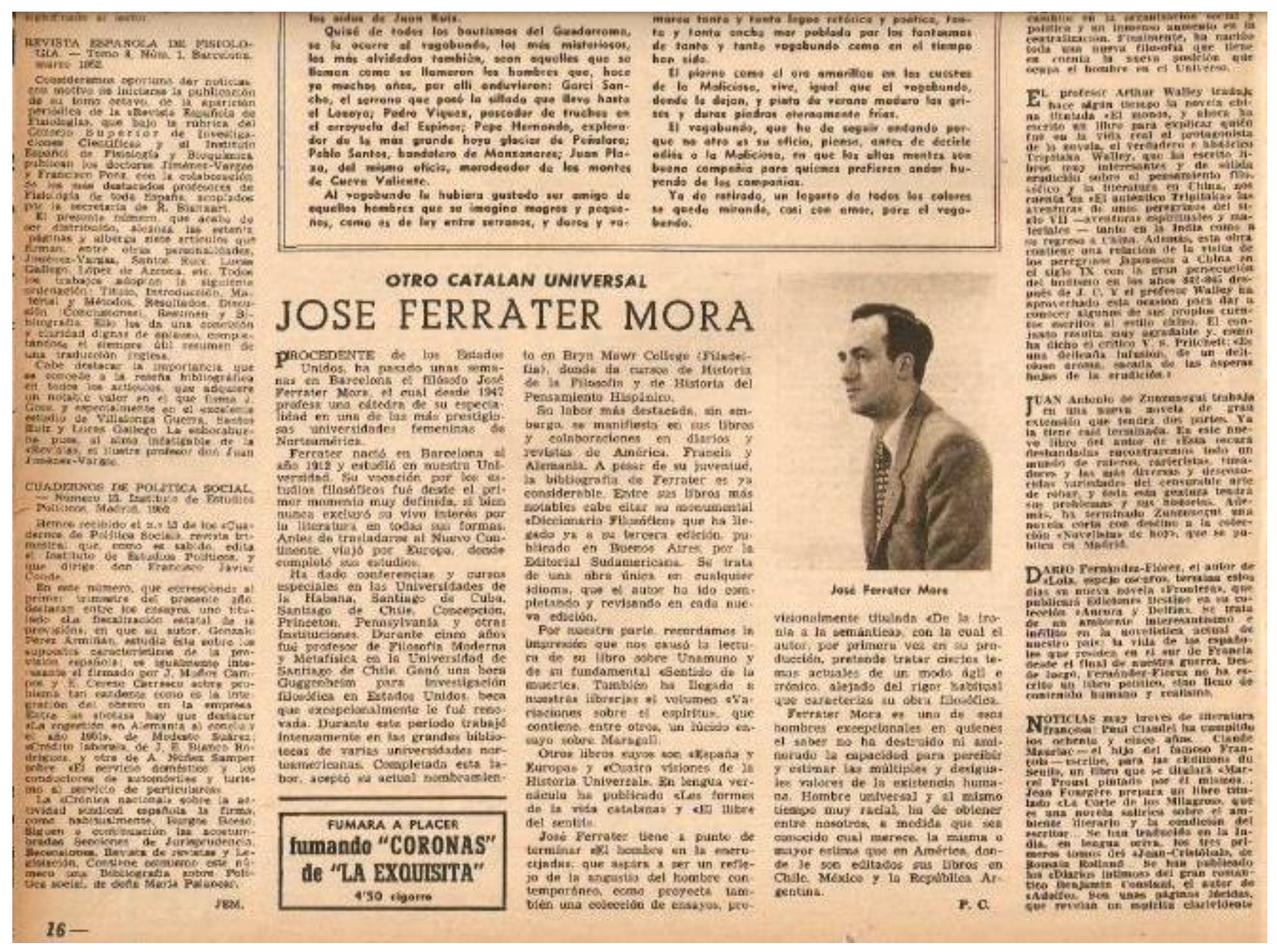

Ilustración 24: Articulo sobre José Ferrater Mora en la Revista Destino (Año 1952)

Tomado de: http://www.todocoleccion.net/coleccionismo-revista-destino/ano-1952-veraneo-tona-aiguafreda-sant-feliu-codines-ferrater-mora-circo-maquillajepayaso $\times 44715384$ 


\section{EL PAIS}

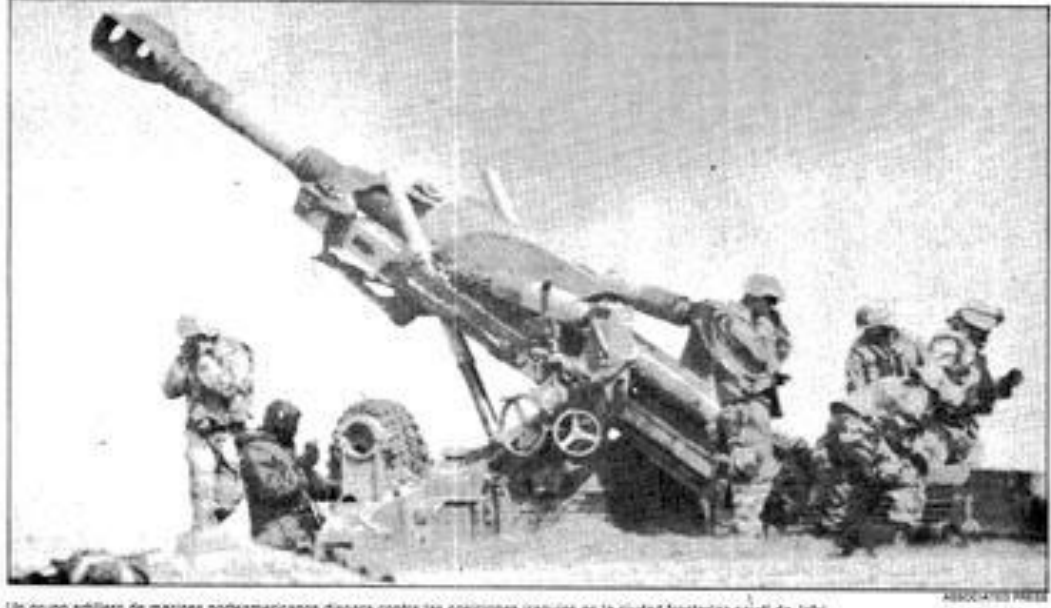

Los portavoces militares aliados aseguran que las bajas enemigas son muy superiores

\section{EE UU admite la muerte de 12 'marines' en la primera ofensiva terrestre iraquí}

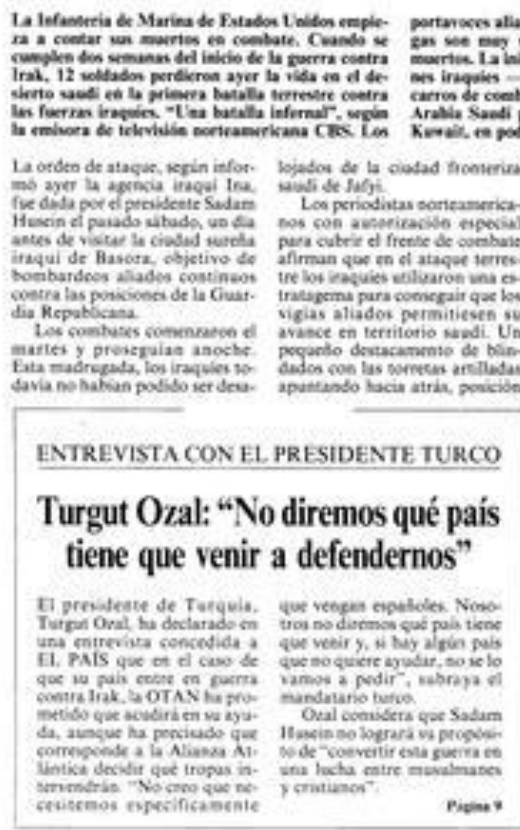

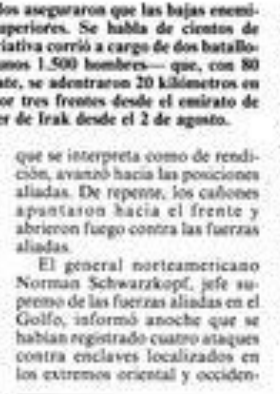

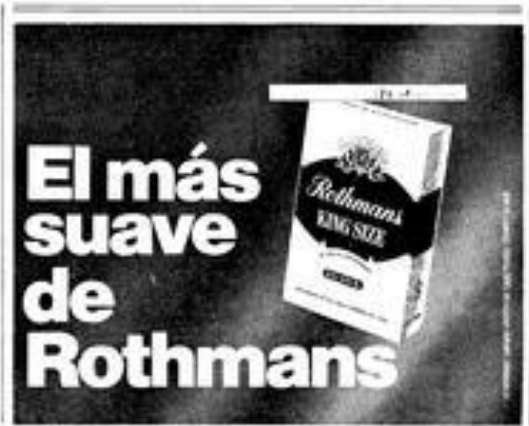

La banca tendrá que identificar a los titulares de cheques al portador

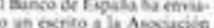
Eo un exrilo a li A Aocucilin a los oylas de absto por el

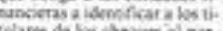

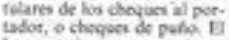

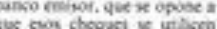
coms active thanciero rethe. serado, pooc onden en una

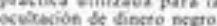

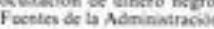
erina 60.0000 millotes ai fordor qoe has cecapedo

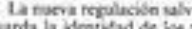
tianet de $\log$ do importe peovenps de la liat. dacibs de actives opacos.
coms los pagatio del fesons

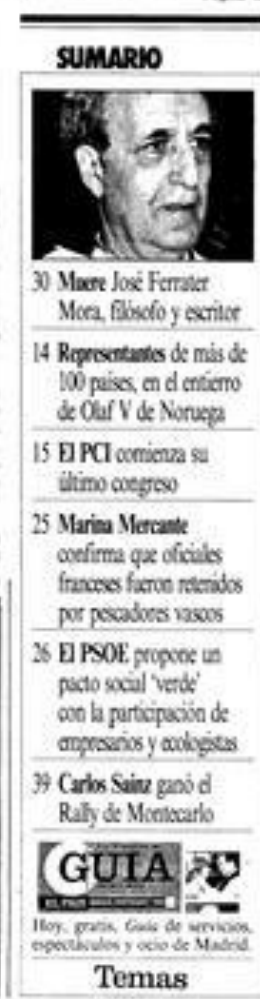

Ilustración 25: Portada del diario El País correspondiente al 31 de enero de 1991, donde se anuncia el fallecimiento de José Ferrater Mora. (Fuente: "Muere José Ferrater Mora, filósofo y escritor" en diario $E l$ País de España. Tomado de: http://elpais.com/diario/1991/01/31/cultura/665276401_850215.html). 


\section{Fallece el filósofo Ferrater Mora}
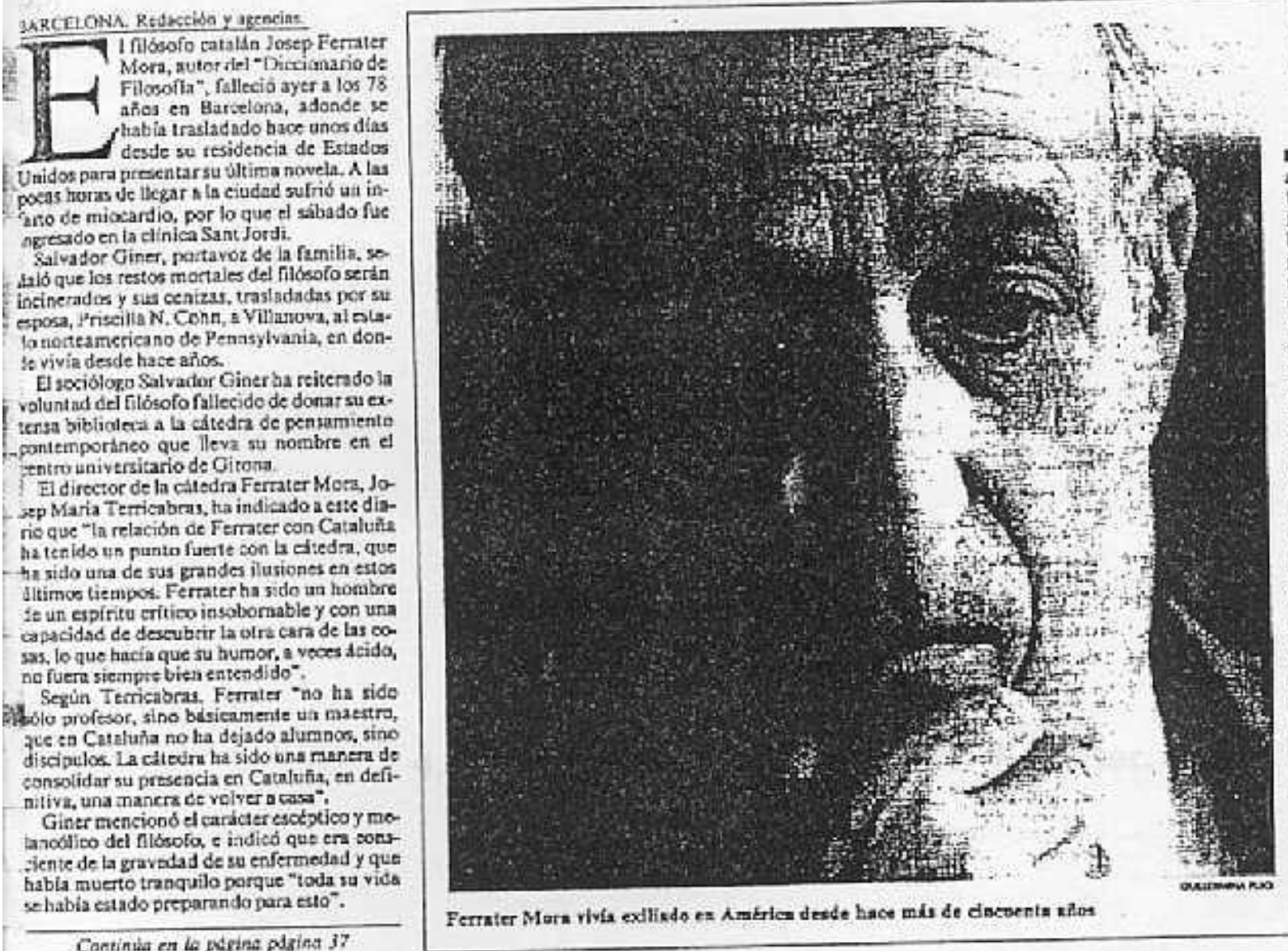

PER BDIL:

Su "Diccionario" le hizo célebre

1. Josep Ferrater Mora nacio el aho 1912 en Barcelonn, en crya Universidar curso estudios ds Hicsonia siroultinearmentr, trarivies. Fn 1 çs publicaba ra pri. mer libro, "Coctel de verdad", rrfuido por Euseni dOrs. En 1939 emprende su vidad dectil:-

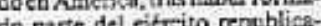

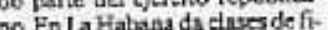
imofía cus no bastan para equilitrar su presupuesta, El astiguo perente de la Editorial La. bor, de Barcelona, entonces cojlindo in race in fanoso -Dicrionario de filosolia". In 1941 Hega in Sactargo do Crive yen 1946 se arisce definituramente en Eradon Unidon A partir de

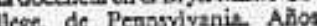
despuds a nombredo direstor del Depurtamento da Filoeoria de la Cienca od mismo seatro. Era miember od lostututo inter naciona de fulcolla, con zese 1984, en 1985 recitioc el premio Principe de Asturias de $\mathrm{Hu}-$ manidades, $y$ en 1988 es invertdo doctor boberis calles por la ALBERTO ARMERIGOL

Ferrater Mara rivis exthisdo en $\lambda$ merica desde hace mis de dacoenta kah 


\section{Fallece en Barcelona el filósofo y escritor catalán Josep Ferrater Mora}

\section{EARERONA II SALTLGO DEL HEY}

El filósafo y novelista catalán, Josep Ferrater C Mora falleciós ayer de un paro cardinco en la Clirica Quinurgica Sunt jordi, donde habta sido internado el pasado sabado. Por voluntad de la fimila, sus restos serain incinerados y traslidados a Estados Unidas país donde residia destle los años 50. Su cxtensa bibliotece será donada ahora al centro universitario de Girona.

Fortalet Mora, que en las ulitias horas habia destron llato uns "insuficteencia car iliosirculabria progresilya" tobas siclo victima ch. un infin (a) cl passudo fo de somina na Als utás Hewar a Barctlon: ilonde isan a presumar su uilsi

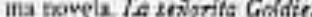

Trax electuarsele sa or mer reconateimitnt is mềilte in ni nikmo actopuertis y $x$ jumediala haspitalizacián. $\mathrm{e}$ escritar sufíb un natevu hat tn en la tenitad ide Cuhacos Intertowas Durinte has huris sizuientes su extaida fue im penratade secclisendase ba crigis rurd hacas hasta gos aI

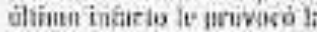
muerle zyot al inesiodia.

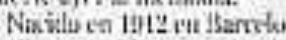

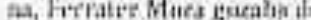

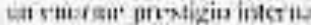

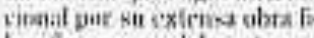

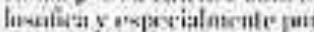

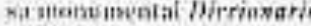
do

Auscue ke hahiz format comas filososto so Ratcelon. hajo ba tuicls de j naquin Xirsa! In maysar parie ite an catcria

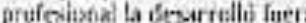

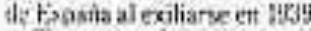

Ttas una pimera mapa et h que ejerció la docenciz en 12. Habans y en in universiogot tre Santiage te Chile (1941. 1549 lue nambrada en 1948 profiesor en el tsrya Maur Co liege de Pensylvania, donde seguía residiento en compa. rits de zu mujer y su hipo.

Ferrater itntoido mpecialmence por is obry de Oriegay Gasuet y Xavier Zubiri destaraha anse Inces par su enoneiirsente dit la histeria de la filit vafia del otas sun tustiasania Leras comis Cuatris atsistes de Ja kilyoria uniokfali (1945), El housar en la enerucijada

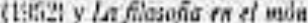
doasi (n)

Fil asia Irrrone sil bhrm usatsina ex sáa ilutu el Weriz-

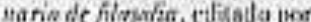
vicier á viz en Mćzicu en 194. resutilaska $y$ anpliatis eat nunurutas massionec lasia th (anza- los cuatro wi jmeses atuales, y suzire fuadn, a dife nsuia de olras nobras dul mis me geneto, escrilo integra riente en so filarin.

En sut olura vit tallan repreMententas las iendencias y dis ciptinas teoricas max dinpare itevie las cbras de rarjrier

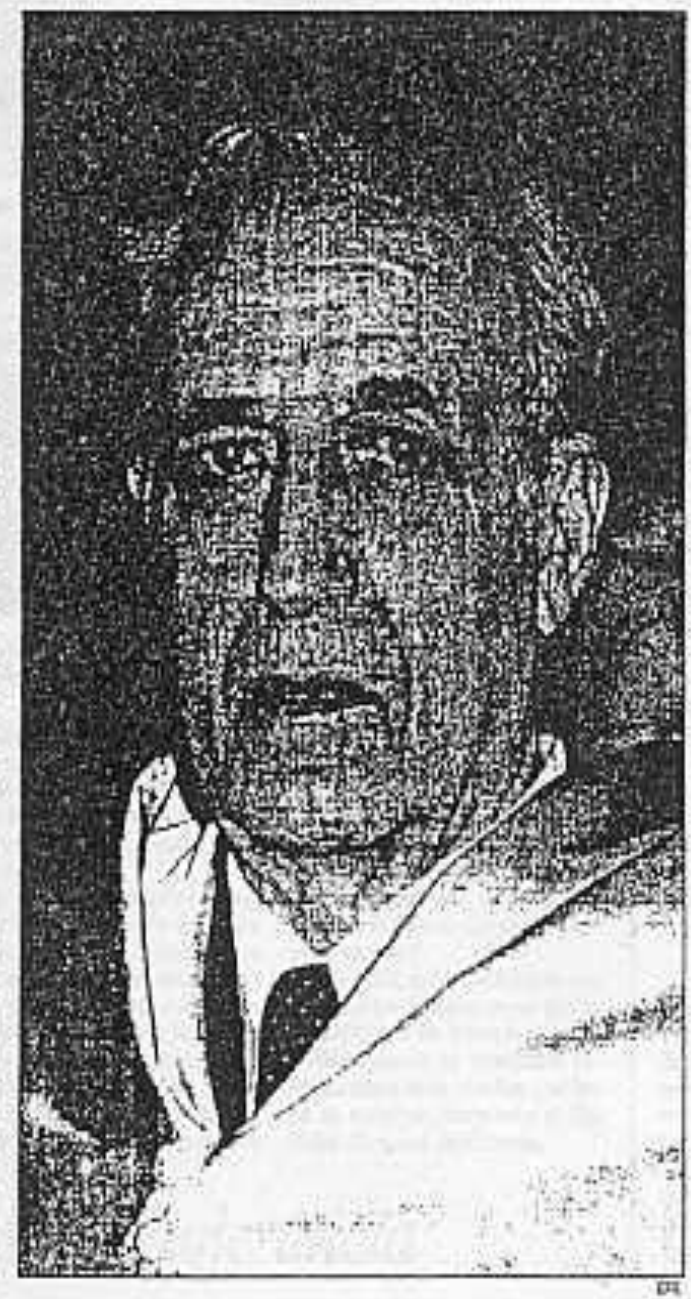

Josep Fermater Mtorn existeocial, hasta las ernira. das en a togica matentibica 0 en la filosofia del lenguaj

Tampoco descuida otras eutestineses $m$ is comprensibes fara el lector comin. So bie trasas carue la potriovra fis of is pend ate muerte, habia excrito en culaboración consu nzijer, Privilla Cahis, taubien liczaciada en filosolíz, un litoro de Eticr adicado sobce Coinhava y su blentidad naciogal pablicó, entre otros, Les for mes de la sida cafalana (1964), El Itiprr del seati?

El perzador gozaba de un gran prestigio internacional por su obra filosofica

(1548) y Tha mandir Catcia. na, Estaqia, Furnpa (14e3).

Docior honoris causa por ta universidad de Bacrelona. miembro de hacgdernia Nur. teanseriona de leniaia Espa. hola, Gran Crux de AJisosa: X detatiog y premia Principe de Astariss de Camutiticion y

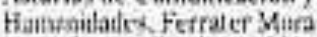

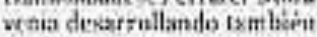
Jende $10 K 5$ tena citrrera cisct: the taulur Fue fintista del iar ntio Nadal en Igs8 tea Er jatzo de la verdad. y estaba en Barcelona en estos dias pard gresentur La acinorila Goldit. que nurecerd ahora pestuma. mente poblicada por la edito ral Seis Farral.

Ilustración 27: Reseña de prensa número 2, acerca del fallecimiento de José Ferrater Mora. Tomado de: http://www.catedraferratermora.cat/ferrater_mora/biblioteca/. 